\title{
Rearrangements of organic peroxides and related processes
}

\author{
Ivan A. Yaremenko, Vera A. Vil', Dmitry V. Demchuk and Alexander O. Terent'ev§
}

\author{
Review \\ Address: \\ N. D. Zelinsky Institute of Organic Chemistry, Russian Academy of \\ Sciences, Leninsky Prospect 47, Moscow, 119991, Russia \\ Email: \\ Alexander O. Terent'ev* - alterex@yandex.ru \\ * Corresponding author \\ $\S \mathrm{Tel}+7-916-385-4080$ \\ Keywords: \\ artemisinin; Baeyer-Villiger; Criegee; Hock; peroxide; rearrangement
}

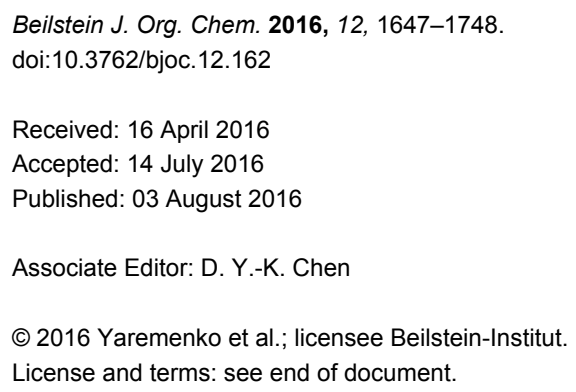

\begin{abstract}
This review is the first to collate and summarize main data on named and unnamed rearrangement reactions of peroxides. It should be noted, that in the chemistry of peroxides two types of processes are considered under the term rearrangements. These are conventional rearrangements occurring with the retention of the molecular weight and transformations of one of the peroxide moieties after O-O-bond cleavage. Detailed information about the Baeyer-Villiger, Criegee, Hock, Kornblum-DeLaMare, Dakin, Elbs, Schenck, Smith, Wieland, and Story reactions is given. Unnamed rearrangements of organic peroxides and related processes are also analyzed. The rearrangements and related processes of important natural and synthetic peroxides are discussed separately.
\end{abstract}

\section{Introduction}

The chemistry of organic peroxides has more than a hundredyear history. Currently, organic peroxides are widely used as oxidizing agents and initiators for free-radical reactions both in industry and in laboratory. These compounds are produced and involved in various natural and biological processes and were explored extensively as antimalarial agents, anthelmintics, and anticancer drugs.

Organic peroxides, such as alkyl hydroperoxides, aryl hydroperoxides, ketone peroxides, dialkyl peroxides, diacyl peroxides, peroxy esters, peroxydicarbonates, peroxyacetals, and inorganic peroxides are the most important radical initiators that are widely used in industrial processes in the manufacture of polymers from unsaturated monomers [1-9].
Nowadays, the progress in the chemistry of organic peroxides is mainly a result of their biological activity and pharmaceutical application. The search of effective antimalarial and antihelminthic drugs is the main challenge of medicinal chemistry of peroxides. According to the World Health Organization (WHO) malaria is a widely distributed illness. About 3.2 billion people remain at risk of malaria and in 2015214 million cases of malaria and 438 thousands deaths from it have been registered [10]. Compounds with high antimalarial [11-23], antihelminthic [24-28], and antitumor activities [29-34] were found among natural, semisynthetic, and synthetic peroxides. The main biologically active frame of these compounds includes five-membered 1,2-dioxolane [35-37], 1,2,4-trioxolane [38,39], and six-membered 1,2-dioxane [40-42], 1,2-dioxene [43], 1,2,4- 
trioxane $[22,44,45]$ cycles. The naturally occuring peroxide artemisinin and its semisynthetic derivatives, artemether, arteether, and artesunate, are applied in large scale for malaria treatment $[46,47]$.

Organic peroxides, their rearrangements and related processes play an important role in the chemistry of oxidation processes. Thus, the key reagent in the Sharpless epoxidation of allylic alcohols [48] and in the manufacture of propylene oxide via the Prilezhaev reaction [49-51] is tert-butyl hydroperoxide. In industry, phenol and acetone are mainly produced by the Hock process, which is based on the rearrangement of cumene hydroperoxide. In 2003, phenol was produced to more than $95 \%$ by this oxidation process [52-54]. Another important application of organic peroxides is the synthesis of lactones from cyclic ketones via the Baeyer-Villiger oxidation and it is one of the methods for the synthesis of commercially important caprolactone from cyclohexanone with peracetic acid $[55,56]$.

Autoxidation processes with formation of hydroperoxides and their subsequent free-radical transformations with generation of carbon- and oxygen-centered radicals are key reactions in the drying process of oil-based and alkyd paints containing double bonds [57-61].

Organic peroxides and their transformation play an important role not only in industrial but also in biological processes. Thus, the firefly luciferase-catalyzed oxidation of luciferin yields the peroxy compound 1,2-dioxetane. This four-membered peroxide cycle is unstable and spontaneously decays to carbon dioxide and excited ketones, which release excess energy through light emission (bioluminescence) [62-65]. The in vivo oxidation of cholesterol by singlet oxygen produces the hydroperoxide cholesterol- $5 \alpha-\mathrm{OOH}$, which undergoes a Hock oxidation to form atheronal $\mathrm{A}$. The latter possesses proatherogenic effects and triggers the development of cardiovascular diseases [66$71]$.

The development of the chemistry of organic peroxides is closely related to the application and preparation of unsaturated compounds, such as epoxides, aldehydes, ketones, carboxylic acids, and their derivatives [72-113]. Organic peroxides are widely used as oxidants in oxidative coupling processes [114120].

Industrial-scale production of readily available and efficient initiators of free radical polymerization and effective biologically active compounds promotes the search for new synthetic methods for peroxides starting from carbonyl compounds, hydrogen peroxide, and hydroperoxides [121-182].
In many cases, rearrangements and related reactions of peroxides are key pathways in laboratory, industrial, and biological processes. The rearrangements of organic peroxides are covered in the literature in hundreds of publications and in several specialized and partial reviews [183-188]. The present review is the first to combine the key data on both, name rearrangements and less well-known rearrangements and related oxidative processes, and to summarize systematically related and different features of these reactions, compares their mechanisms, and assesses the prospects of their application.

By definition, a rearrangement is a migration of an atom or a group of atoms from one atom to another within the same molecule [189]. In contrast, a rearrangement of organic peroxides means a change in the structure of the starting molecule to form an isomeric compound without a peroxy group [183]. The terminology of rearrangements of organic peroxides and related processes encountered in the literature shows that this definition is not generally applicable as rearrangements of peroxides can give both isomeric and non-isomeric compounds either containing a peroxy group or without the latter. In most cases, a rearrangement involves the migration or cleavage of the peroxide group in an intermediate molecule, and the stability of the latter is responsible for the further pathway of the process.

The review covers main studies published over the last 15-20 years with a brief excursion to the history of the development of various reactions and transformations. The review consists of three parts: the first part considers named transformations of organic peroxides (Figure 1), the second one deals with unnamed reactions, and the third part covers transformations of some important natural and synthetic peroxides. Since the term "rearrangements", as applied to transformations of peroxides, is not clearly defined all parts of the review include processes related to rearrangements.

\section{Review \\ 1 Named rearrangements of organic peroxides}

Rearrangements of organic peroxides are the key steps in many well-known processes such as the Baeyer-Villiger (BV), the Criegee and Hock reactions, the Kornblum-DeLaMare rearrangement, Dakin, and Elbs oxidation.

The BV oxidation is widely used in organic synthesis for the preparation of esters and lactones and the Criegee reaction is applied to transform tertiary alcohols into ketones and aldehydes. The Hock rearrangement is a key step in the cumene (cumene-phenol) process and the Kornblum-DeLaMare is an important tool in the synthesis of functionalized ketones and alcohols, including $\gamma$-hydroxy enones. The Dakin oxidation 


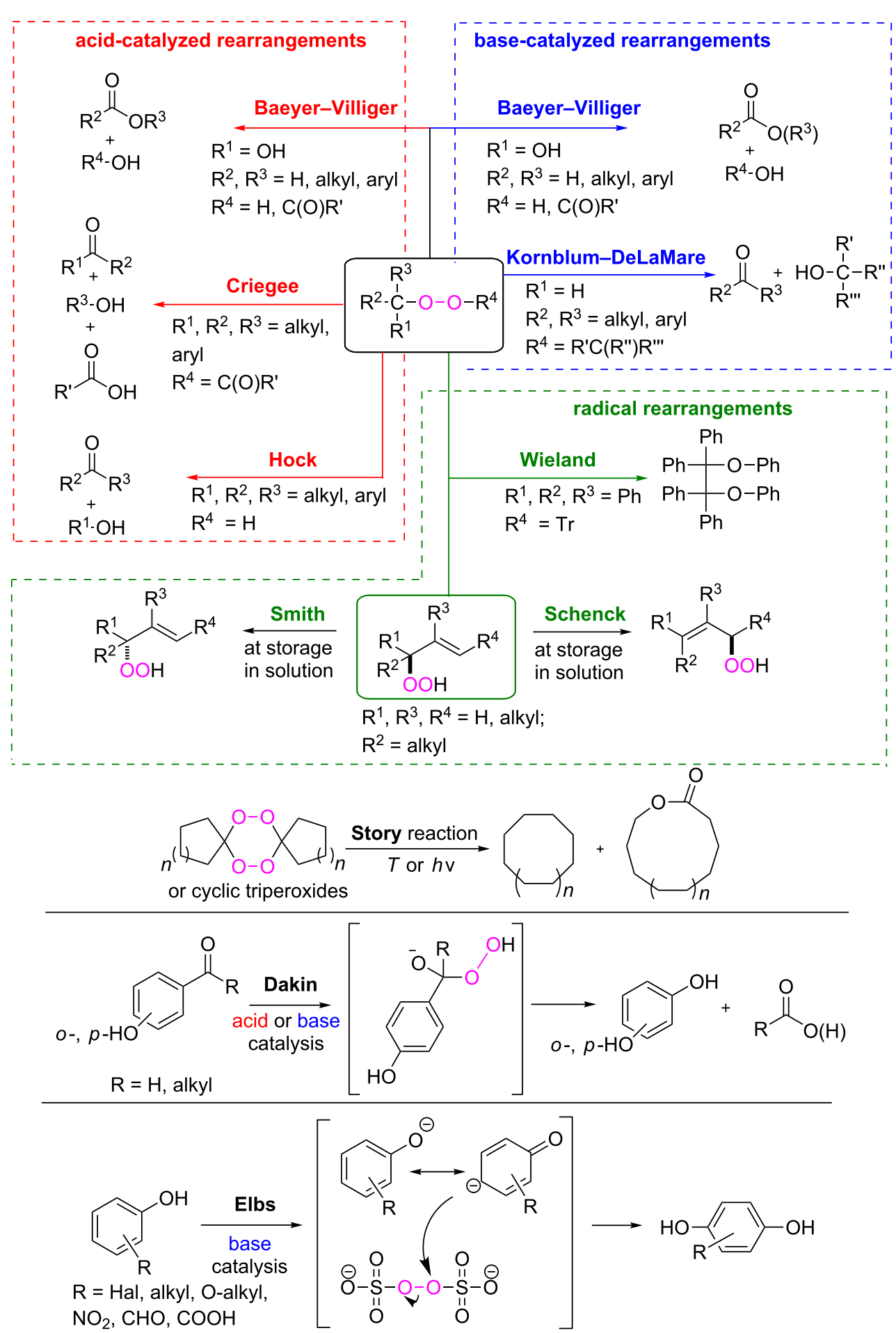

Figure 1: The named transformations considered in this review.

finds application for the synthesis of phenols from arylaldehydes or aryl ketones and the Elbs persulfate oxidation allows the preparation of hydroxyphenols from phenols. Finally, the Schenck and Smith rearrangements are of interest in allyl hydroperoxide transformations.

\subsection{Baeyer-Villiger oxidation}

The BV reaction is the oxidation of ketones or aldehydes $\mathbf{A}$ under the action of hydrogen peroxide, hydroperoxides, Caro's acid $\left(\mathrm{H}_{2} \mathrm{SO}_{5}\right)$, or organic peracids to yield esters, lactones, or carboxylic acids B (Scheme 1) [190,191]. 


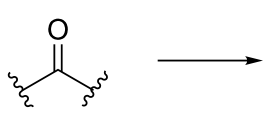

A

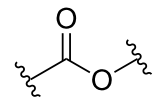

B
Scheme 1: The Baeyer-Villiger oxidation.

Baeyer and Villiger accomplished the oxidation of ketones to esters for the first time in 1899 while they attempted the reaction of Caro's acid $\left(\mathrm{H}_{2} \mathrm{SO}_{5}\right)$ with menthone, tetrahydrocarvone, and camphor to transform these compounds into the corresponding lactones [192-194].

Since that time, this reaction has shown to be of general applicability and it has gained wide application for the oxidation of carbonyl compounds of different structures. In this reaction, cyclic ketones are transformed into lactones, acyclic ketones, into esters and aldehydes into carboxylic acids. The BV oxidation is one of the most important reactions in organic chemistry because it produces lactones, which are useful synthetic products in polymer, agrochemical, and pharmaceutical industry.

$m$-Chloroperbenzoic, peracetic, and perfluoroacetic acids, as well as hydrogen peroxide/protic acid, hydrogen peroxide/ Lewis acid, and hydrogen peroxide/base systems are widely employed in the Baeyer-Villiger oxidation [185,194,195].

The general mechanism of the peracid-promoted Baeyer-Villiger oxidation involves two main steps. In the first step, the oxygen atom of the peroxide moiety of the peracid 2 binds to the carbonyl group of ketone $\mathbf{1}$ to form the tetrahedral intermediate $\mathbf{3}$ which is referred to as the Criegee intermediate. The next step involves the concerted migration of the $\mathrm{R}^{2}$ group to the peroxide oxygen atom, resulting in the formation of ester 4 and carboxylic acid 5 (Scheme 2).

The ability of peracids to oxidize cyclic and acyclic ketones and aldehydes to the corresponding lactones, esters, and carboxylic acids decreases in the series peroxotrifluoroacetic acid $>$ monopermaleic acid $>$ mono-o-perphthalic acid $>3,5$-dinitroperbenzoic acid $>p$-nitroperbenzoic acid $>$ MCPBA $\approx$ performic acid $>$ perbenzoic acid $>$ peracetic acid $>>\mathrm{H}_{2} \mathrm{O}_{2}>$ $t$-BuOOH [196].

The migratory ability of substituents in the Criegee intermediate decreases in the following series: tertiary alkyl $>$ cyclohexyl $>$ secondary alkyl $>$ benzyl $>$ phenyl $>$ primary alkyl $>$ cyclopentyl, cyclopropyl $>$ methyl. In some cases, stereoelectronical effects strongly influence the regioselectivity of the reaction, specifically the ability of the migrating $\mathrm{C}-\mathrm{C}$ to align with the back of the breaking $\mathrm{O}-\mathrm{O}$ bond, and the presence or absence of strain in cyclic ketone substrates [197,198]. The strongest electron-donating group migrates in unsymmetrical ketones [199].

There are thousands of publications on the Baeyer-Villiger reaction. In the latest reviews published by Krow [195] in 1993 and by Renz and Meunier [185] in 1999, the field of application, the reactivity of substrates, and the reaction kinetics and mechanisms are considered in detail. In the review by Strukul, special emphasis was placed on metal-catalyzed Baeyer-Villiger oxidations [196]. Green approaches in the Baeyer-Villiger reaction were highlighted by another review [200].

The present review covers a more modern aspect of this reaction, viz., the performance of the process using hydrogen peroxide. Oxidizing systems containing hydrogen peroxide as the oxidizing agent allow the usual and asymmetric oxidation of the substrate to the target product with high conversion and yield. In recent years, the inexpensive, commercially available, and environmentally friendly $\mathrm{H}_{2} \mathrm{O}_{2}$ was utilized in the Baeyer-Villiger reaction with increasing frequency. Various catalysts that activate hydrogen peroxide, such as heterogeneous catalysts based on solid acids [201], zeolites [202,203], Se [204], As [205], Co [206], sulfonated organic ion exchange resins [203,207], and homogeneous catalysts based on Pt [208], Zr [209], Re [210,211], Se [212,213], As [205], Mo [214], Co [215], Brønsted [216], and Lewis acids [217] are described in the literature. The general mechanism of a Lewis acid-catalyzed Baeyer-Villiger rearrangement is presented in Scheme 3 [200,218].

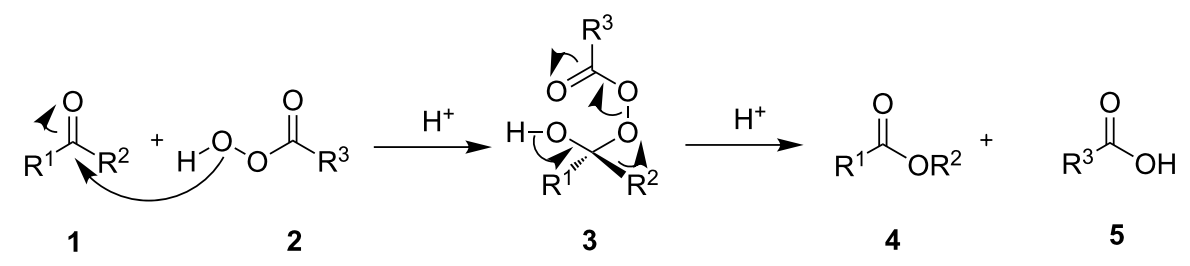




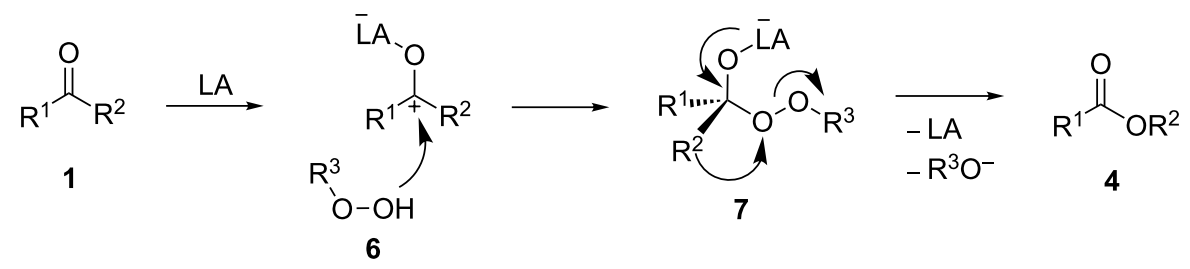

Scheme 3: General mechanism of the Lewis acid-catalyzed Baeyer-Villiger rearrangement.

Scheme 4 shows the theoretically studied mechanism of the oxidation reaction promoted by $\mathrm{H}_{2} \mathrm{O}_{2}$ and the Lewis acid $\mathrm{BF}_{3}$ $[217,219]$. In the first step, the hydrogen peroxide-boron trifluoride complex 8 reacts with ketone 9 to form adduct 10. The latter intermediate rearranges through transition state $\mathbf{1 1}$ into the tetrahedral peroxyacetal intermediate $\mathbf{1 2}$. Then $\mathrm{BF}_{3}$ migrates to another oxygen atom through transition state $\mathbf{1 3}$ to give the second Criegee intermediate 14. The decomposition of intermediate $\mathbf{1 4}$ finally produces $\mathbf{1 5}$, hydrogen fluoride (16) and ester 17.

Despite the fact that the Baeyer-Villiger reaction is known since 1899 , the mechanism of this reaction is still not fully understood. The nature of the acid catalyst [220] and the type of O-O-bond cleavage in the Criegee intermediate [221] were found to play an important role in this reaction. Probably the hydrogen bonds in Baeyer-Villiger reactions play an important role [222]. The tetramolecular transition states TS1 and TS2 are considered to be the two key steps determining the course of the oxidation: the nucleophilic addition of a peroxy acid molecule to ketone (TS1) and the migration of $\mathrm{R}$ and cleavage of $\mathrm{O}-\mathrm{O}$ bond (TS2). Thus, electrophilic substrates favor TS1 and nucleophilic migrating groups prefer TS2 (Scheme 5).

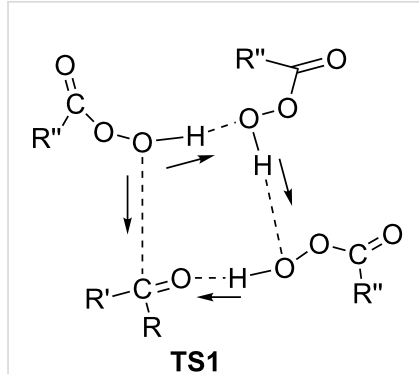

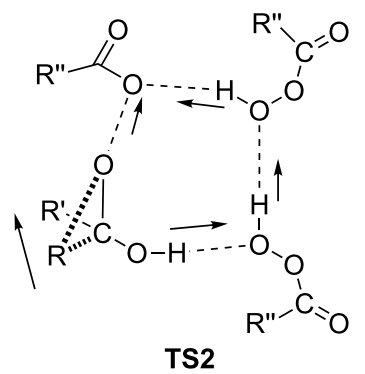

Scheme 5: Proton movements in the transition states of the Baeyer-Villiger oxidation.

The dependence of the course of the Baeyer-Villiger oxidation on the type of $\mathrm{O}-\mathrm{O}$-bond cleavage in the Criegee intermediate was studied in the oxidation reaction of 1,2-quinone $\mathbf{1 8}$ with perbenzoic acid [221]. The reaction gave two oxidation prod-

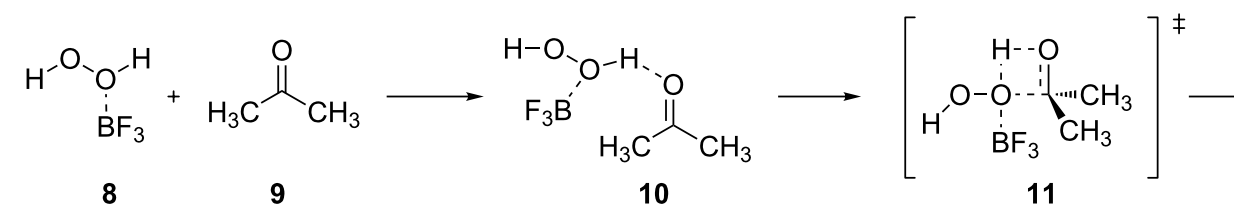

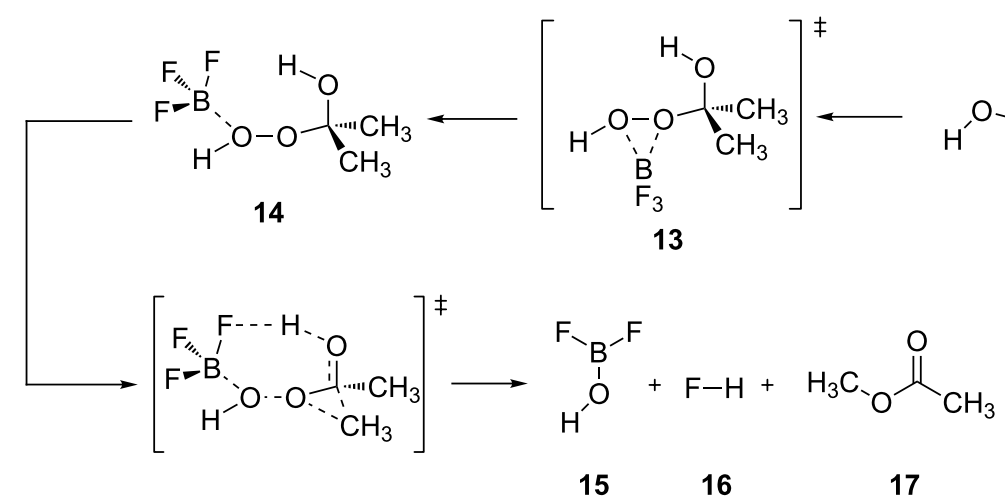


ucts - anhydride $\mathbf{2 0}$ and the seven-membered $\alpha$-ketolactone 21. The investigation of the reaction mechanism demonstrated that the formation of the seven-membered $\alpha$-ketolactone $\mathbf{2 1}$ proceeds through the heterolytic $\mathrm{O}-\mathrm{O}-$ bond cleavage in Criegee intermediate 19, whereas the homolytic $\mathrm{O}-\mathrm{O}$ cleavage affords anhydride 20 (Scheme 6).

The acid-catalyzed Baeyer-Villiger oxidation of cyclic epoxy ketones 22 produces lactones of type $\mathbf{2 3}$, which convert into carbenium ions $\mathbf{2 4}$ in the presence of the acid. Subsequently, these ions can be transformed with participation of $\mathrm{H}_{2} \mathrm{O}_{2}$ through three different pathways into dihydroperoxides $\mathbf{2 5}$, dicarboxylic acids 28, carboxylic acids 26, and keto carboxylic acids 27 (Scheme 7, Table 1) [223].

The oxidation of isophorone oxide (29) is an industrial process for the production of dimethylglutaric acid $\mathbf{3 0}$ (Scheme 8) [223].

Acyl phosphate 32 can be synthesized from acyl phosphonate 31 in high yield by oxidation with $\mathrm{H}_{2} \mathrm{O}_{2}$ (Scheme 9) [224].

The Baeyer-Villiger oxidation provides a valuable tool for the synthesis of oxygenated natural products [218,225,226] as

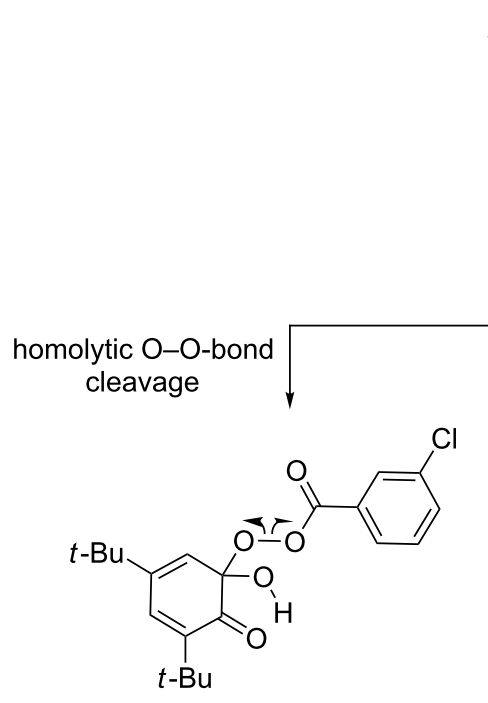

19

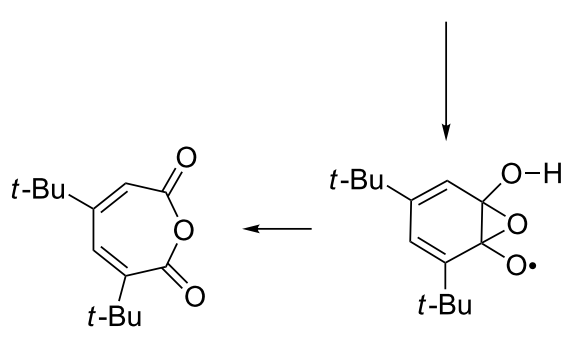

20

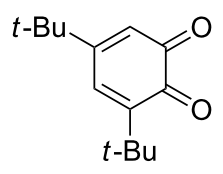

18

$m-\mathrm{CPBA}$

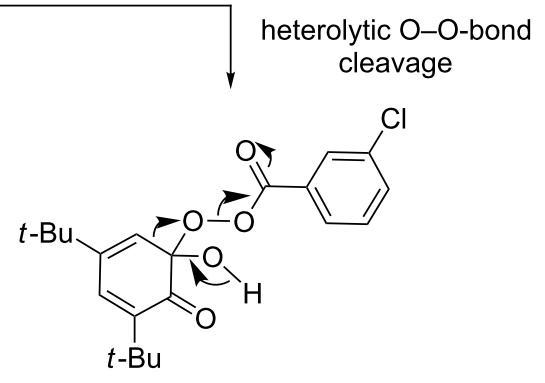

19<smiles>[Z18]c1cc([10BH2])coc(=O)c1=O</smiles>

Scheme 6: The dependence of the course of the Baeyer-Villiger oxidation on the type of O-O-bond cleavage in the Criegee intermediate.

Table 1: Oxidation of cyclic epoxy ketones 22a-c by $\mathrm{H}_{2} \mathrm{O}_{2}$.

\begin{tabular}{|c|c|c|c|c|c|}
\hline Epoxy ketone & $\mathrm{R}$ & $25, \%$ & $26, \%$ & $27, \%$ & $28, \%$ \\
\hline $22 a$ & $\mathrm{Me}$ & $25 a, 12$ & $26 a, 6$ & $27 a, 15$ & $28 a, 53$ \\
\hline $22 b$ & Et & 25b, 19 & a & a & a \\
\hline 22c & $\mathrm{Ph}$ & $25 c, 19$ & - & $27 c, 35$ & $28 c, 18$ \\
\hline
\end{tabular}

aThe aqueous phase consisted of a complex mixture and could not be analyzed. 

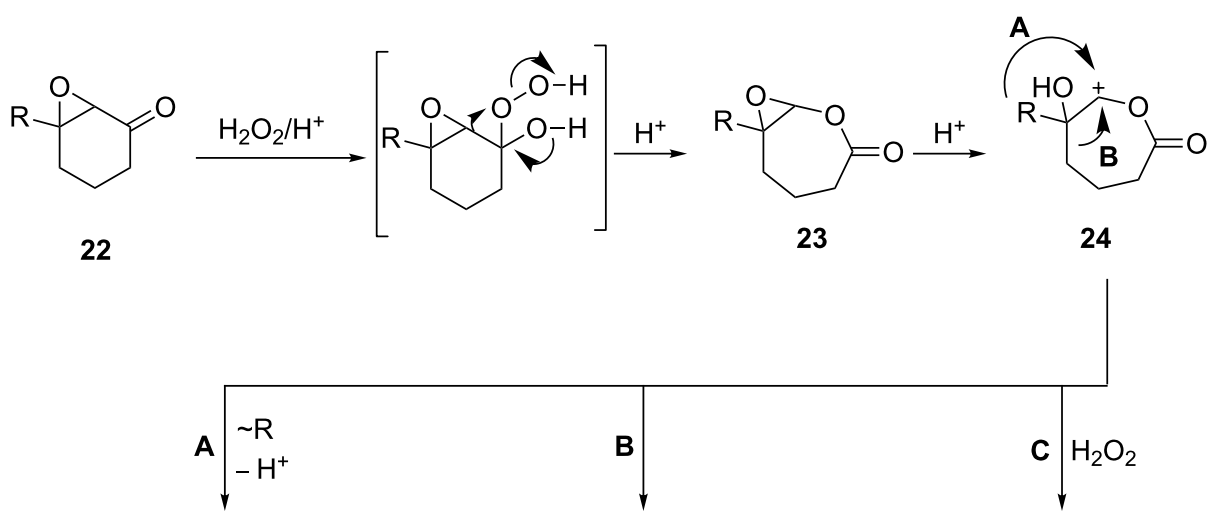<smiles>[R]C1OC(=O)CCCC1=O</smiles>

$\downarrow \mathrm{H}_{2} \mathrm{O}_{2} / \mathrm{H}^{+}$

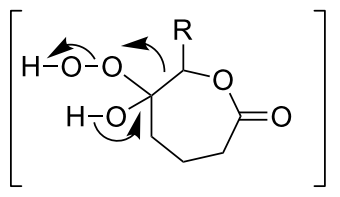

$\downarrow \mathrm{H}^{+}$<smiles>[R]C1OC(=O)CCCC(=O)O1</smiles>
$2 \mathrm{H}_{2} \mathrm{O}_{2}$<smiles>[R]C(O)OO</smiles>

25<smiles>O=C(O)CCCC(=O)O</smiles>

28<smiles>[R]C(=O)C1CCCC(=O)O1</smiles><smiles>O[OH2+2]</smiles><smiles>[R]O[C@]1([2H])CCCC(=O)O1</smiles><smiles>C[I+]I</smiles><smiles>[R]C(=O)OC1CCCC(=O)O1</smiles><smiles>C1CCCC1</smiles><smiles>[R]C(=O)[CH-]C=O</smiles>

26 $\downarrow \mathrm{H}_{2} \mathrm{O}_{2}$<smiles>O=C(O)CCCC(=O)O</smiles>

28<smiles>[R]C1CCC(=O)OC(OO)C1O</smiles><smiles>[R]C1(O)CCCC(=O)OC1O[Na]</smiles>

$\downarrow \mathrm{H}_{2} \mathrm{O}$<smiles>[R]C1(O)CCCC(=O)OC(O)O1</smiles><smiles>CI</smiles><smiles>[R]C(=O)CCCC(=O)O</smiles>

27 


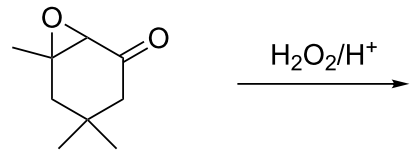

29<smiles>CC(C)(CC(=O)O)CC(=O)O</smiles>

30
Scheme 8: Oxidation of isophorone oxide 29.

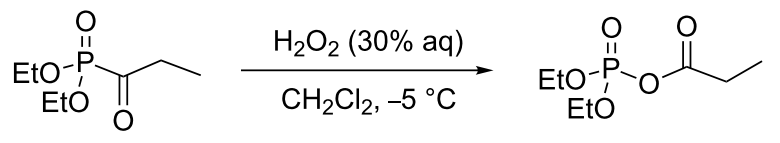

31
32, $90 \%$
Scheme 9: Synthesis of acyl phosphate 32 from acyl phosphonate 31. exemplified by the synthesis of aflatoxin $\mathrm{B}_{2}(\mathbf{3 6}$, Scheme 10) [227].

The Baeyer-Villiger reaction is also a key step in the multistep synthesis of cannabinergic lactones from dimethylheptylresorcinol. Two regioisomeric cannabinergic lactones were obtained, one of which possessed pronounced affinity towards the CB1 receptor and lower affinities for $\mathrm{mCB} 2$ and $\mathrm{hCB} 2$ receptors [228].

Oxidation with $\mathrm{H}_{2} \mathrm{O}_{2}$-acid systems: With in situ generated peracids from carbodiimide, hydrogen peroxide, and carboxylic acids as catalysts ketones $\mathbf{3 7}$ are rearranged to lactones $\mathbf{3 8}$ (Scheme 11) [229].

3,4-Dimethoxybenzoic acid (40) was prepared with 78\% yield by a Baeyer-Villiger reaction of substrate 39 with $30 \% \mathrm{H}_{2} \mathrm{O}_{2}$,<smiles>C=C1C=CC(=O)C=C1OC</smiles>

33<smiles>C1=COCC1</smiles>

34

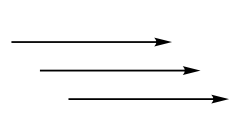

$\mathrm{MeO}$<smiles>COc1cc2c(c(C(C)=O)c1[18O])[C@H]1CCO[C@H]1O2</smiles>

35 $\left(\mathrm{CF}_{3} \mathrm{CO}\right)_{2} \mathrm{O}, \mathrm{H}_{2} \mathrm{O}_{2}$ (urea complex) $\mathrm{CH}_{2} \mathrm{Cl}_{2}$ rt, 45 h, $63 \%$<smiles>COc1cc2c(c3oc(=O)c4c(c13)CCC4=O)[C@H]1CCO[C@H]1O2</smiles><smiles>COc1cc2c(c(OC(C)=O)c1O)[C@H]1CCO[C@H]1O2</smiles>

aflatoxin $B_{2}(36)$<smiles>[R]C1([R])CCC(=O)CC1</smiles>
catalyst (10 mol \%), DIC (3.6 equiv), $\mathrm{H}_{2} \mathrm{O}_{2}$ (3 equiv), NMI (10 mol \%) $\mathrm{CH}_{2} \mathrm{Cl}_{2}, 3 \mathrm{~h}, \mathrm{rt}$

37

$\mathrm{R}^{1}, \mathrm{R}^{2}=\mathrm{H}, t-\mathrm{Bu}$, aryl, OC(O)Ph, alkyl $\mathrm{R}^{3}=\mathrm{Boc} ; \mathrm{R}^{4}=\mathrm{Bn}$<smiles>[R]C1([R])CCOC(=O)CC1</smiles>

38, $26-96 \%$<smiles>[R]N[C@@H](CC(=O)O)C(=O)O[Z1]</smiles>

catalyst or<smiles>O=C(O)c1c(F)c(F)c(F)c(F)c1F</smiles> 


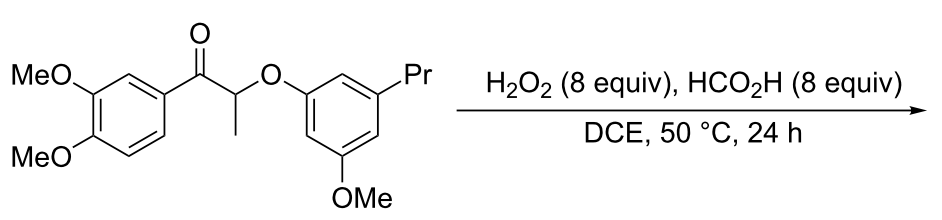

39<smiles>CCCc1cc(O)cc(OC)c1</smiles>

$40,78 \%$
42

Scheme 12: Synthesis of 3,4-dimethoxybenzoic acid (40) via Baeyer-Villiger oxidation.

$\mathrm{HCOOH}$ and 1,2 -dichloroethane at $50^{\circ} \mathrm{C}$ for $24 \mathrm{~h}$ (Scheme 12) [230].

Oxone is a convenient reagent for the transformation of $\alpha, \beta$ unsaturated ketones $\mathbf{4 3}$ of determined stereochemistry into vinyl acetates $\mathbf{4 4}$ via the Baeyer-Villiger reaction in dry DMF for 7-39 h (Scheme 13) [231].

Oxidation with $\mathrm{H}_{2} \mathrm{O}_{2}$-heteroorganic catalyst systems: The activity of oxidizing systems such as $\mathrm{H}_{2} \mathrm{O}_{2}$ /aryl benzyl selenoxide and $\mathrm{H}_{2} \mathrm{O}_{2}$ /diaryl diselenide is similar to that of $m$-chloroperbenzoic acid [212,232,233]. The main advantage of these selenium-containing systems is that the catalysts are regenerated and can therefore be used at low loadings [234236]. Some results of the oxidation of ketones and aldehydes

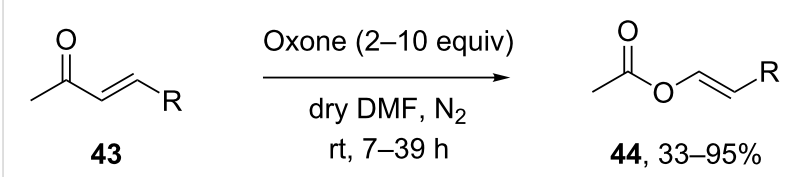

$\mathrm{R}=$ aryl, vinyl, alkyl, etc.

Scheme 13: Oxone transforms $\alpha, \beta$-unsaturated ketones 43 into vinyl acetates 44

45a-c to the corresponding esters $46 \mathbf{a}-\mathbf{c}$ using the $\mathrm{H}_{2} \mathrm{O}_{2} /$ aryl benzyl selenoxide system are collected in Table 2 [232].

The oxidation results of ketones $47 \mathbf{a}, \mathbf{b}$ and aldehydes $47 \mathbf{c}-\mathbf{e}$ to lactones $48 \mathbf{a}, \mathbf{b}$ and carboxylic acids $49 \mathbf{a}-\mathbf{c}$ promoted by the $\mathrm{H}_{2} \mathrm{O}_{2}$ /diaryl diselenide system is presented in Table 3 [212].

Table 2: Baeyer-Villiger oxidation of aldehyde 45a and ketones 45b,c using the $\mathrm{H}_{2} \mathrm{O}_{2}$ /aryl benzyl selenoxide system.
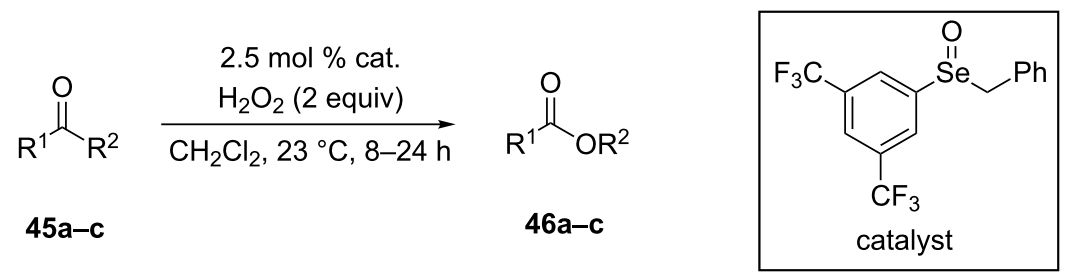

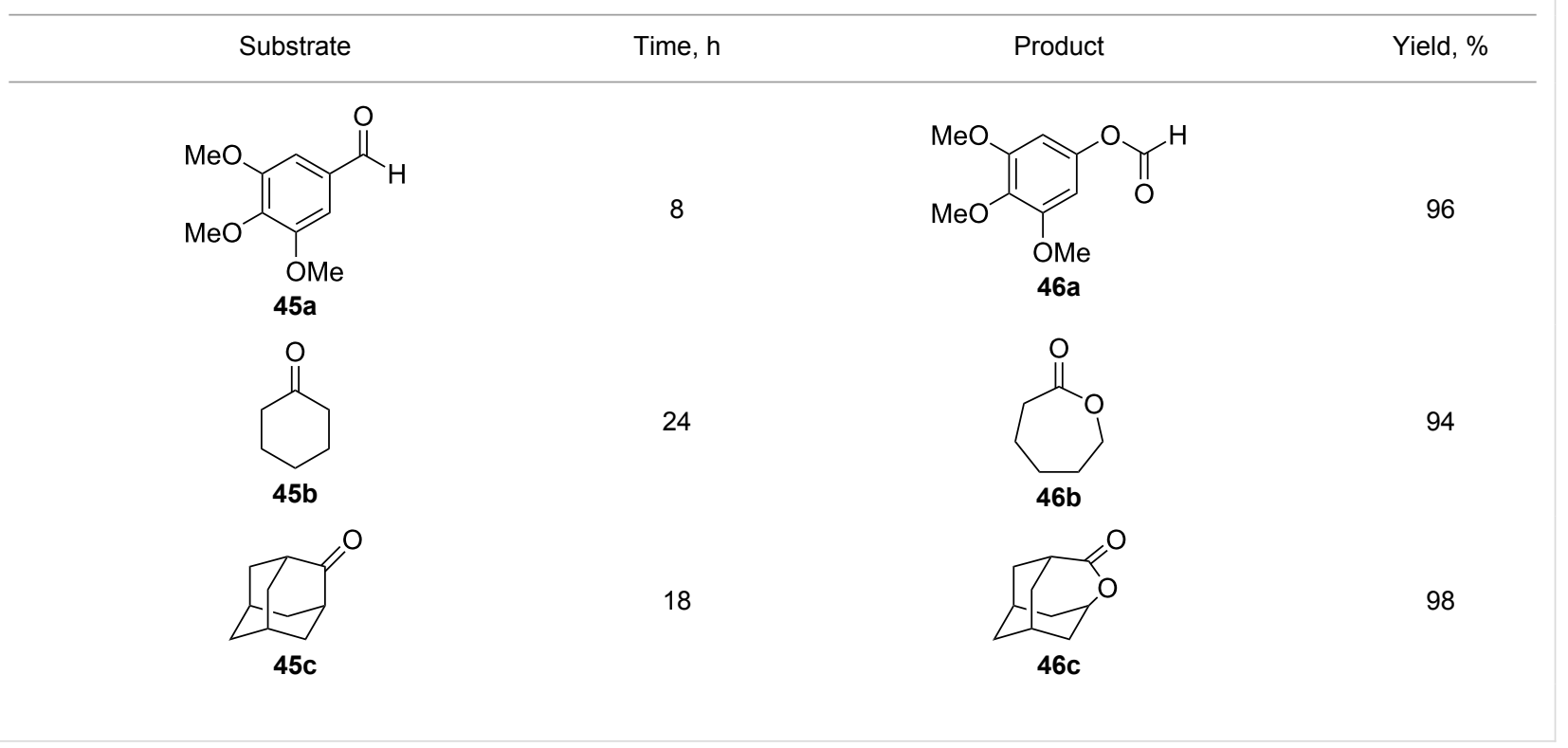


Table 3: Baeyer-Villiger oxidation of ketones $47 \mathbf{a}, \mathbf{b}$ and aldehydes $47 \mathrm{c}-\mathrm{e}$ promoted by the $\mathrm{H}_{2} \mathrm{O}_{2} /$ diaryl diselenide system.

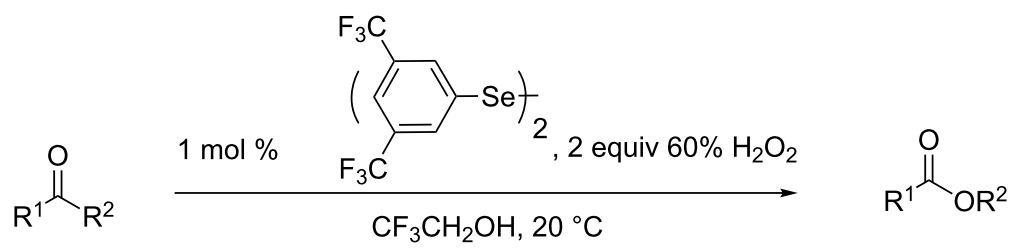

$47 a-e$

$48 a, b, 49 a-c$

\begin{tabular}{|c|c|c|c|c|}
\hline Ketone & Time, $\mathrm{h}$ & Product & Conversion, \%a & $\begin{array}{l}\text { Selectivity (BV } \\
\text { product), \% }\end{array}$ \\
\hline
\end{tabular}

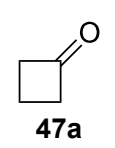

$\square_{47 b}^{O}$

47b<smiles>O=Cc1ccc([N+](=O)[O-])cc1</smiles><smiles>CCCCCCCC=O</smiles>

$47 d^{b}$<smiles>O=CCCc1ccccc1</smiles>

$47 e^{b}$
1<smiles>O=C1CCCO1</smiles>

48a

8<smiles>O=C1CCCCO1</smiles><smiles>O=C(O)c1ccc([N+](=O)[O-])cc1</smiles>

$49 a$

3<smiles>CCCCCCCC(=O)O</smiles>

49b<smiles>O=C(O)CCc1ccccc1</smiles>

49c
95

98

99

94

88

96

$>90$

aDetermined by GC; ${ }^{\mathrm{b}} 60^{\circ} \mathrm{C}$.

In the first step of the catalytic cycle of the Baeyer-Villiger oxidation using diaryl diselenide $\mathbf{5 0}$ and hydrogen peroxide seleninic acid $\mathbf{5 1}$ is generated, which is then oxidized to perseleninic acid 52. Oxidation of the ketone 45 by perseleninic acid 52 involves the intermediate peroxide 53 (Scheme 14) [235].

Similarly, the versatile 4-methylenebutanolides 55 can be prepared from $(E)$-2-methylenecyclobutanones $\mathbf{5 4}$ in the presence of $(\mathrm{PhSe})_{2} / \mathrm{H}_{2} \mathrm{O}_{2}$ at room temperature (Scheme 15). Likely the Baeyer-Villiger reaction proceeds through the formation of benzeneseleninoperoxoic anhydride $\left[\mathrm{PhSe}(\mathrm{O}) \mathrm{O}_{2} \mathrm{O}\right.$ in the first step, which then transforms to the active oxidant benzeneseleninoperoxoic acid $\mathrm{PhSe}(\mathrm{O}) \mathrm{OOH}$ [233].

The Baeyer-Villiger oxidation of $(E)$ - $\alpha, \beta$-unsaturated ketones to $(E)$-vinyl esters was performed with hydrogen peroxide and

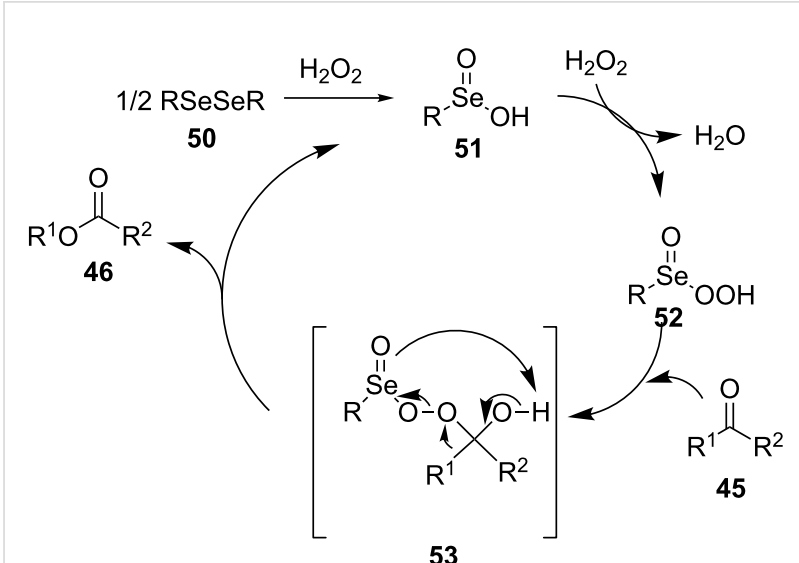

Scheme 14: The Baeyer-Villiger oxidation of ketones 45 using diaryl diselenide and hydrogen peroxide. 
<smiles>[R]C=C1CCC1=O</smiles>

54

$\mathrm{R}=\operatorname{aryl}$

$$
\underset{0.05 \text { equiv }(\mathrm{PhSe})_{2}}{\stackrel{\mathrm{MeCN}, \mathrm{rt}, 24 \mathrm{~h}}{\longrightarrow}}
$$

55, $40-82 \%$<smiles>[R]C=C1CCC(=O)O1</smiles>

Scheme 15: Baeyer-Villiger oxidation of (E)-2-methylenecyclobutanones.

dibenzyl diselenide as pre-catalyst at room temperature [236]. Catalyzed by the dibenzyl diselenide, $\beta$-ionone (56) was oxidized by $\mathrm{H}_{2} \mathrm{O}_{2}$ with formation of $(E)$-2-(2,6,6-trimethylcyclohex-1-en-1-yl)vinyl acetate (57) with $91 \%$ yield (Scheme 16 ) [237].

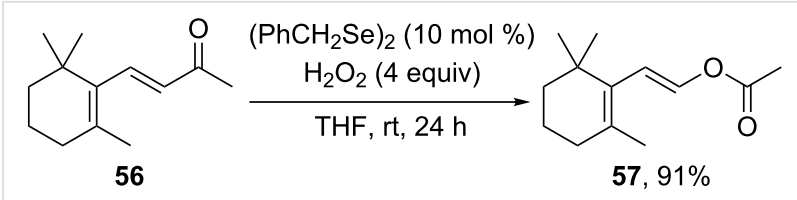

Scheme 16: Oxidation of $\beta$-ionone (56) by $\mathrm{H}_{2} \mathrm{O}_{2} /(\mathrm{BnSe})_{2}$ with formation of $(E)-2-(2,6,6$-trimethylcyclohex-1-en-1-yl)vinyl acetate (57).

The Baeyer-Villiger oxidation of ketones $\mathbf{5 8 a}-\mathbf{f}$ to form esters 59a-f can be accomplished in good yields in the presence of $\mathrm{H}_{2} \mathrm{O}_{2}$ and arsenic-containing ion exchange resins on polystyrene as the catalyst (Table 4) [203,205].

The mechanism of the oxidation of ketones $\mathbf{5 8 a}-\mathbf{f}$ by hydrogen peroxide in the presence of arsonated polystyrene $\mathbf{6 0}$ as the

Table 4: Oxidation of ketones $58 \mathrm{a}-\mathrm{f}$ with $90 \% \mathrm{H}_{2} \mathrm{O}_{2}$ catalyzed by arsonated polystyrene.

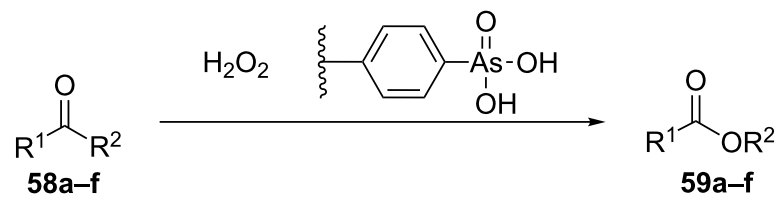

Ketone Time, $\mathrm{h} \quad$ Ketone $/ \mathrm{H}_{2} \mathrm{O}_{2}$, ratio Product
ketone consumed, \%<smiles>CC1CCCC1=O</smiles>

$58 a$<smiles>CC1CCCCC1=O</smiles>

$58 b$<smiles>O=C1CCCCC1c1ccccc1</smiles>

58c<smiles>O=C1CCCCCC1</smiles>

58d<smiles>C=CCC1CCCCC1=O</smiles>

$58 e$<smiles>CC(=O)C(C)(C)C</smiles>

$58 f$
11

1

5

5

15

23

9

25

5

5<smiles>CC1CCCC(=O)O1</smiles>

$59 a$<smiles>CC1CCCCC(=O)O1</smiles>

59b<smiles>O=C1CCCCC(c2ccccc2)O1</smiles>

59c<smiles>O=C1CCCCCCO1</smiles>

59d<smiles>C=CCC1CCCCC(=O)O1</smiles>

$59 e$
29

92

70

100<smiles>CC(=O)OC(C)(C)C</smiles> 
catalyst is shown in Scheme 17. First, hydrogen peroxide reacts with the arsonic acid 60 to form peroxyarsonic acid 61 or it adds to ketones $\mathbf{5 8 a}-\mathbf{f}$ to form vicinal hydroperoxyalkanols $\mathbf{6 3}$. In the second step the peroxyarsonic acid $\mathbf{6 1}$ adds to ketones 58a-f or the vicinal hydroperoxyalkanols 63 interact with arsonated polystyrene $\mathbf{6 0}$ under formation of perester $\mathbf{6 2}$. Finally, the decomposition of $\mathbf{6 2}$ gives esters $\mathbf{5 9} \mathbf{a}-\mathbf{f}$.
A number of other modern oxidizing systems are based on transition metal-peroxo complexes. The use of transition metal complexes were also used as catalysts for the Baeyer-Villiger reaction and the first example was documented in 1978 [196,214]. For example, Mo(VI) peroxo complexes 64 and 65 were employed as the catalysts and $90 \% \mathrm{H}_{2} \mathrm{O}_{2}$ served as the oxidizer (Table 5).
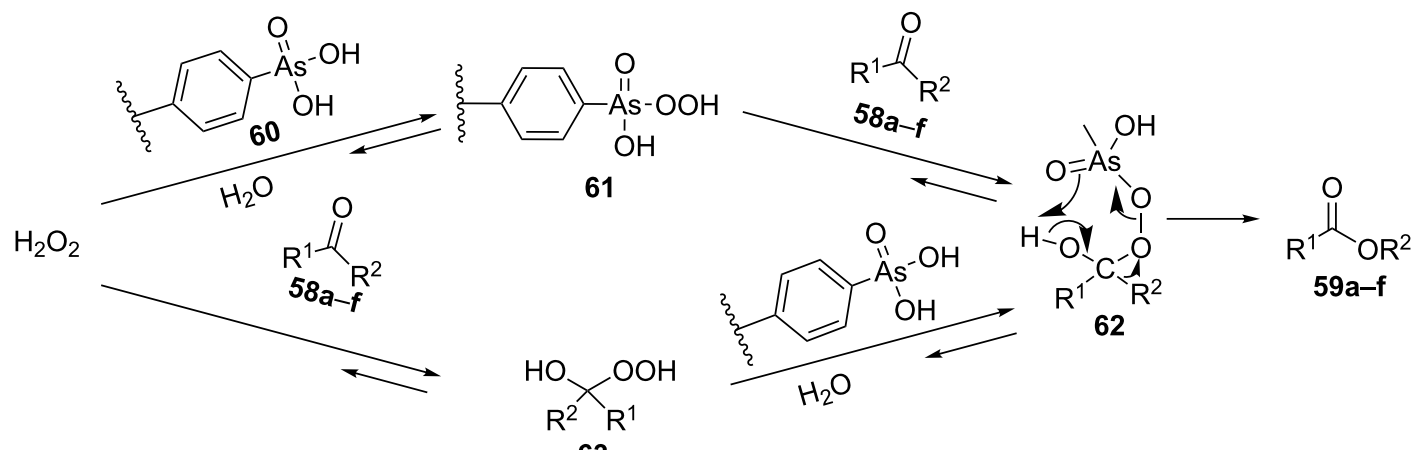

Scheme 17: The mechanism of oxidation of ketones $58 a-f$ by hydrogen peroxide in the presence of arsonated polystyrene 60 .

Table 5: Oxidation of cyclic ketones $45 b, 47 b$ and $58 a, b$ by $\mathrm{H}_{2} \mathrm{O}_{2}$ in the presence of $\mathrm{Mo}(\mathrm{VI})$ peroxo complex 64 as the catalyst.

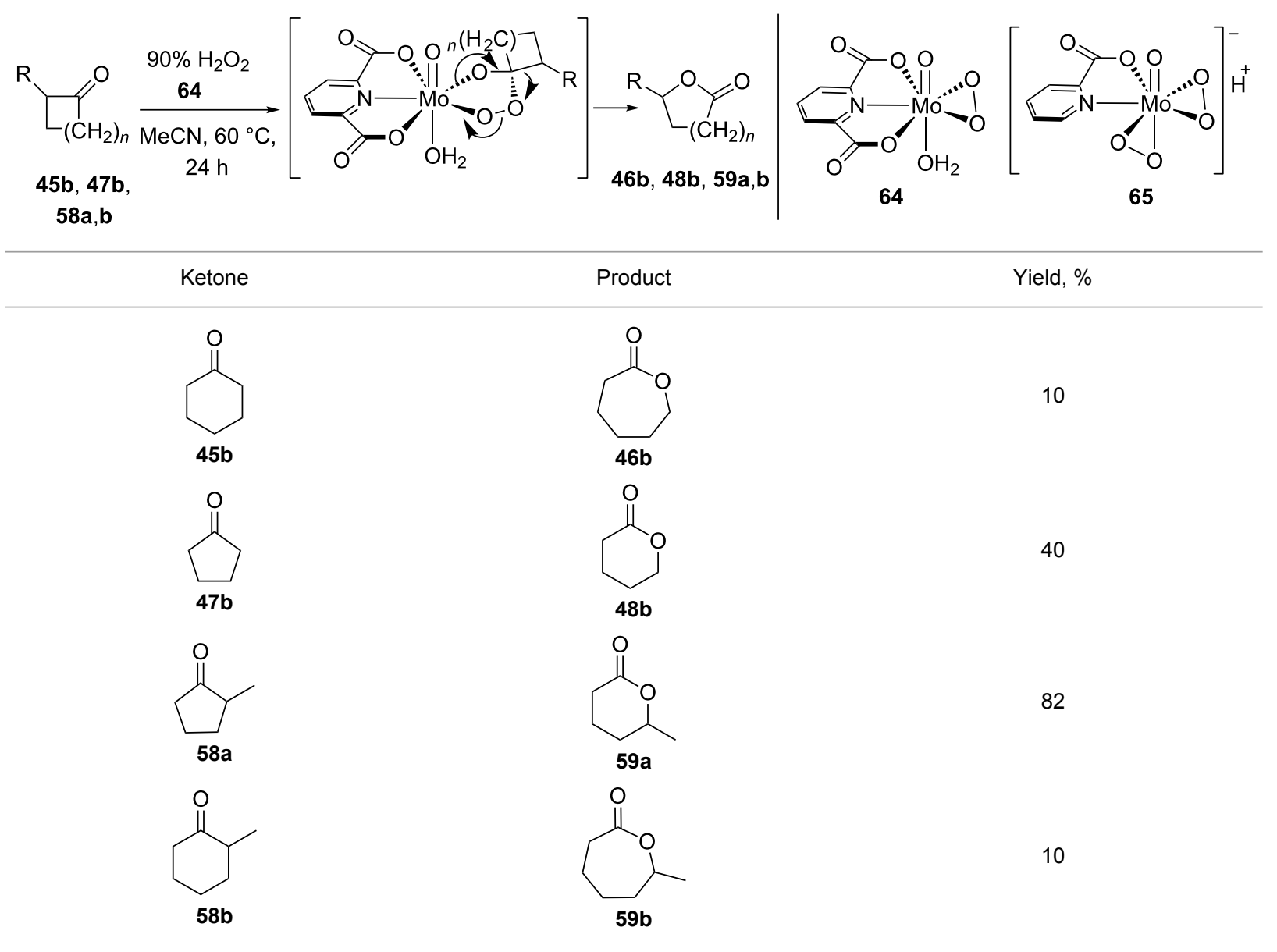


The results obtained from the reactions using molybdenum systems have stimulated the search for new catalysts based on transition metal complexes. The usage of the platimum complex $\left[(\mathrm{dppe}) \mathrm{Pt}\left(\mathrm{CF}_{3}\left(\mathrm{CH}_{2} \mathrm{Cl}_{2}\right)\right] \mathrm{BF}_{4}\left(\mathbf{6 6} \cdot \mathrm{BF}_{4}\right)\right.$ allowed the oxidation of 2-methylcyclohexanone (58b) in the presence of $32 \%$ $\mathrm{H}_{2} \mathrm{O}_{2}$ at room temperature to form 6-methylcaprolactone (59b) in $22 \%$ yield (Scheme 18) [238].

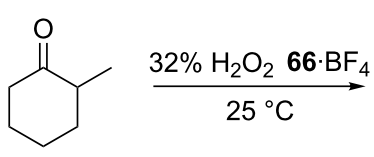

$58 b$

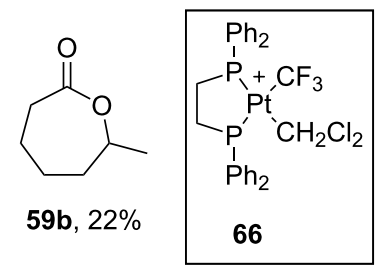

Scheme 18: Oxidation of ketone (58b) by $\mathrm{H}_{2} \mathrm{O}_{2}$ to 6-methylcaprolactone $(59 b)$ catalyzed by $\mathrm{Pt}$ complex $66 \cdot \mathrm{BF}_{4}$.

Acyclic ketones 67 could be oxidized to the corresponding esters 68 in the presence of the catalyst $[(\mathrm{dppb}\} \mathrm{Pt}(\mu-\mathrm{OH})]_{2}{ }^{2+}$, where dppb is butane-1,4-diylbis(diphenylphosphane) (Scheme 19) [208].

The oxidation mechanism of ketones 67 is displayed in Scheme 20 .

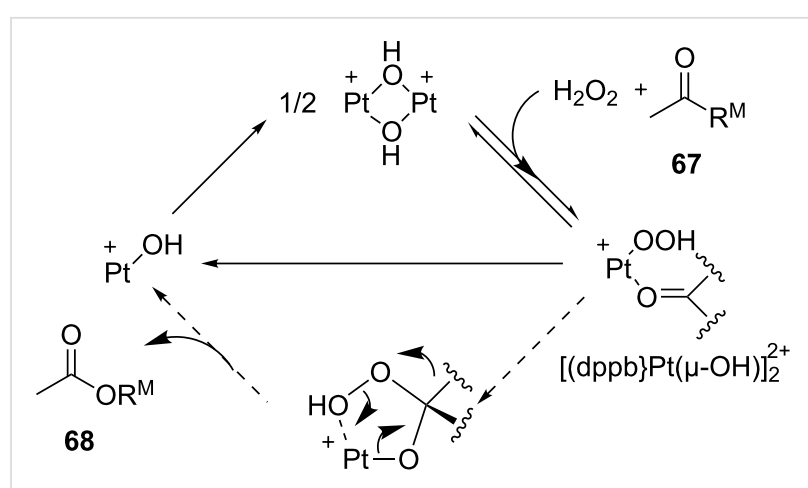

Scheme 20: The mechanism of oxidation of ketones 67 in the presence of $[(\mathrm{dppb}\} \mathrm{Pt}(\mu-\mathrm{OH})]_{2}{ }^{2+}$ and $\mathrm{H}_{2} \mathrm{O}_{2}$.

The use of variable-valence metal complexes opened up a new field of application of the Baeyer-Villiger oxidation and there are now dozens of studies on this topic [196,239-246].

Hydroxylated and methoxylated benzaldehydes 69 (Scheme 21) and acetophenones $\mathbf{7 2}$ (Scheme 22) can be oxidized to the corresponding phenols $\mathbf{7 0 a}-\mathbf{d}$, and $\mathbf{7 3}$ in good yields in the presence of the $\mathrm{H}_{2} \mathrm{O}_{2} / \mathrm{MeReO}_{3}$ system in ionic liquids [bmim] $\mathrm{BF}_{4}$ or [bmim] $\mathrm{PF}_{6}$ [247]. Benzoic acids 71a-d, 74 and phenyl esters 75a-d were reported as oxidation byproducts.

Sn-containing mesoporous silica nanospheres (Sn-MSNSs) with uniform crater-like mesopores exhibited high activities in

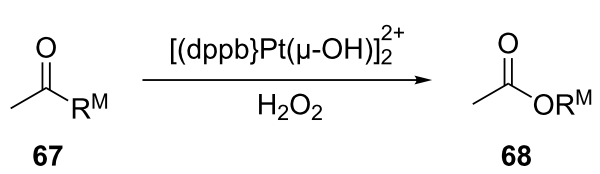

$\left.\left.\mathrm{R}^{\mathrm{M}}=n-\mathrm{Bu}, t-\mathrm{Bu}, s-\mathrm{Bu}, \mathrm{Ph},\right\rangle_{\mathrm{H}}^{\mathrm{H}}\right) \mathrm{C}_{\mathrm{Ph}}^{\mathrm{P}}$

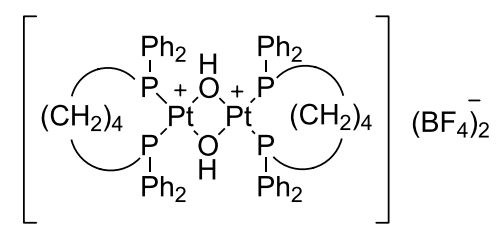

$[(\mathrm{dppb}\} \mathrm{Pt}(\mu-\mathrm{OH})]_{2}^{2+}$

Scheme 19: Oxidation of ketones 67 with $\mathrm{H}_{2} \mathrm{O}_{2}$ in the presence of $[(\mathrm{dppb}\} \mathrm{Pt}(\mu-\mathrm{OH})]_{2}{ }^{2+}$.<smiles>[R]c1ccc(C=O)c([R])c1[R]</smiles>

69a: $\mathrm{R}^{1}=\mathrm{OH}, \mathrm{R}^{2}=\mathrm{R}^{3}=\mathrm{H}$

69b: $R^{1}=\mathrm{R}^{2}=\mathrm{H}, \mathrm{R}^{3}=\mathrm{OH}$

69c: $R^{1}=H, R^{2}=R^{3}=\mathrm{OCH}_{3}$

69d: $R^{1}=\mathrm{OCH}_{3}, R^{2}=\mathrm{R}^{3}=\mathrm{H}$

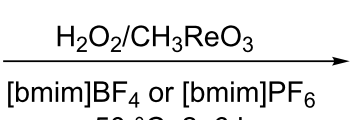

$50{ }^{\circ} \mathrm{C}, 2-6 \mathrm{~h}$<smiles>[R]c1ccc(O)c([R])c1[R]</smiles>

$70 a, 84 \%$

70b, $95 \%$

70 c, $80 \%$

70d, $75 \%$<smiles>[R]c1ccc(C(=O)O)c([R])c1[R]</smiles>

71a, $16 \%$

$71 b, 5 \%$

71c, $20 \%$

71d, $15 \%$ 
<smiles>[R]c1ccc(C(C)=O)c([R])c1</smiles>

72a: $R^{1}=\mathrm{OH}, \mathrm{R}^{2}=\mathrm{H}$

72b: $R^{1}=H, R^{2}=\mathrm{OH}$

72c: $\mathrm{R}^{1}=\mathrm{H}, \mathrm{R}^{2}=\mathrm{OCH}_{3}$

72d: $\mathrm{R}^{1}=\mathrm{OCH}_{3}, \mathrm{R}^{2}=\mathrm{H}$

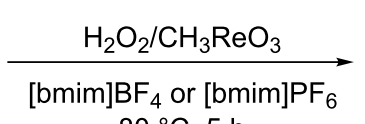

$80^{\circ} \mathrm{C}, 5 \mathrm{~h}$<smiles>[R]c1ccc(O)c([R])c1</smiles>

70 a, $45 \%$

70b, $90 \%$

$73,76 \%$

$70 d, 55 \%$<smiles>[R]c1ccc(C(=O)O)c([R])c1</smiles>

71a, $-\%$

71b, $-\%$

$74,3 \%$

71d, $30 \%$<smiles>[R]c1ccc(OC(C)=O)c([R])c1</smiles>

75a, $55 \%$

75b, $10 \%$

75c, $11 \%$

75d, $15 \%$

Scheme 22: Oxidation of acetophenones 72 in the presence of the $\mathrm{H}_{2} \mathrm{O}_{2} / \mathrm{MeReO}_{3}$ system.

the Baeyer-Villiger oxidation of 2-adamantanone (45c) (Scheme 23) [248].<smiles>O=C1C2CC3CC(C2)CC1C3</smiles>

$45 c$

$$
\begin{aligned}
& 1 \text { equiv } \mathrm{H}_{2} \mathrm{O}_{2}(35 \% \text { aq) } \\
& 3 \text { wt equiv } \mathrm{Sn}-\mathrm{MSNSs}(\mathrm{Si} / \mathrm{Sn}=106)
\end{aligned}
$$$$
\text { dioxane, } 90^{\circ} \mathrm{C}, 3 \mathrm{~h}
$$

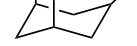

46c, $55-85 \%$
Scheme 23: Baeyer-Villiger oxidation of 2-adamantanone $(\mathbf{4 5 c})$ in the presence of $\mathrm{Sn}$-containing mesoporous silica nanospheres ( $\mathrm{Sn}$ MSNSs).

The Baeyer-Villiger rearrangement of 2-adamantanone (45c) was performed using hydrogen peroxide $\left(\mathrm{H}_{2} \mathrm{O}_{2}\right)$ and stannosilicate zeolites with nanosheet morphology and MFI topology (Sn-MFI-ns) as highly efficient catalysts [249]. The Sn-beta zeolites prepared by a steam-assisted conversion method are efficient catalysts for the Baeyer-Villiger reaction of cyclohexanone to $\varepsilon$-caprolactone [250]. A mesoporous $\mathrm{Mg}-\mathrm{Al}$-mixed oxide showed good catalytic efficiency in the Baeyer-Villiger oxidation of a series of ketones to the corresponding lactones and esters in the presence of diluted aqueous $\mathrm{H}_{2} \mathrm{O}_{2}$ and benzonitrile [251].

The Baeyer-Villiger oxidation of ketones $\mathbf{7 6}$ under the action of oxygen to the related esters 77 was performed using metal-free carbon (Ketjen Black) as a solid catalyst and benzaldehyde as the sacrificing agent. This metal-free carbon catalyst showed excellent catalytic activity and can be recycled after the reaction under oxygen atmosphere at $50{ }^{\circ} \mathrm{C}$ (Scheme 24) [252].

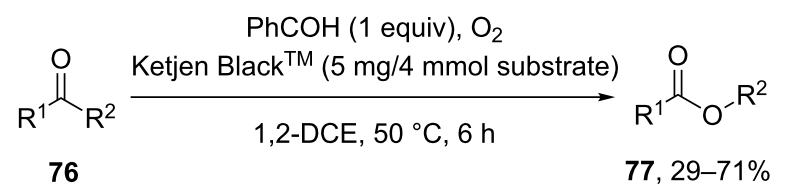

$\mathrm{R}^{1}, \mathrm{R}^{2}=$ cyclic ketones, adamantanone, tert-butyl methyl ketone

Scheme 24: Aerobic Baeyer-Villiger oxidation of ketones 76 using metal-free carbon.

The boron-containing catalysts $\mathrm{LiB}\left(\mathrm{C}_{6} \mathrm{~F}_{5}\right)_{4}$ or $\mathrm{Ca}\left[\mathrm{B}\left(\mathrm{C}_{6} \mathrm{~F}_{5}\right)_{4}\right]_{2}$ were developed for the Baeyer-Villiger oxidation of ketones with aqueous $\mathrm{H}_{2} \mathrm{O}_{2}$ to give the lactones in high yields $[253,254]$.

A regioselective Baeyer-Villiger oxidation of functionalized cyclohexenones $\mathbf{7 8}$ lead to dihydrooxepine structures $\mathbf{7 9}$. Here, the combination of $\mathrm{SnCl}_{4}$ and bis(trimethylsilyl)peroxide (BTSP), in the presence of trans-1,2-diaminocyclohexane as the ligand, generated the desired products 79 in high yields (Scheme 25) [255].<smiles>[R]c1ccccc1C(=O)CCCC</smiles>

$\mathrm{SnCl}_{4}$ ( 0.5 equiv), $\mathbf{L}$ ( 0.5 equiv $)$ BTSP ( 3 equiv)

$\mathrm{CH}_{2} \mathrm{Cl}_{2}(0.1 \mathrm{M}), 4 \AA \mathrm{MS}, 25^{\circ} \mathrm{C}$

78<smiles>[R]CCC(=O)Oc1ccccc1CC</smiles>

$79,79-83 \%$

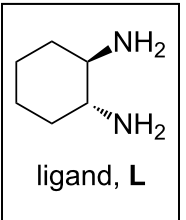

$\mathrm{R}=\mathrm{alkyl}, \mathrm{aryl}, \mathrm{Bn}$ 
The $\mathrm{Co}_{4} \mathrm{HP}_{2} \mathrm{Mo}_{15} \mathrm{~V}_{3} \mathrm{O}_{62}$-catalyzed oxidation of aldehydes and ketones $\mathbf{8 0}$ by hydrogen peroxide in ionic liquid [TEBSA] $\left[\mathrm{BF}_{4}\right]$ resulted in carboxylic acids and esters $\mathbf{8 1}$ in good to high yields (Scheme 26) [256].

Oxidation with $\mathrm{H}_{2} \mathrm{O}_{2}$-base systems: The oxidative cleavage of ketones $\mathbf{8 2}$ with hydrogen peroxide in alkaline solution yielded carboxylic acids $\mathbf{8 4}$. The authors suggested that the reaction of a ketone with the hydroperoxide anion resulted in the intermediate esters $\mathbf{8 3}$, which hydrolyzed in the basic reaction medium with formation of acids 84 (Scheme 27) [257].

The use of hydrotalcites in the Baeyer-Villiger oxidation of various ketones resulted in high yields of the corresponding lactones or esters [258-260]. The esters 86 were synthesized by the reaction of ketones $\mathbf{8 5}$ with $\mathrm{H}_{2} \mathrm{O}_{2}$ and benzonitrile under basic reaction conditions $\left(\mathrm{KHCO}_{3}\right)$ with the intermediate generation of peroxyimidic acids. This oxidation can be successfully applied to alkyl-containing ketones to give the target products in yields of $30-91 \%$ and good regioselectivity $7: 1$ to $20: 1$ (Scheme 28) [261].

Asymmetric oxidation: Asymmetric Baeyer-Villiger oxidation reactions can be performed using chiral acetals, organic hydroperoxides, chiral metal complexes and organocatalysts $[262,263]$. There are also Green chemistry approaches for Baeyer-Villiger oxidations based on enzyme-mediated processes, which are used for the preparation of chiral lactones. This type of biocatalysis is useful in synthetic chemistry and

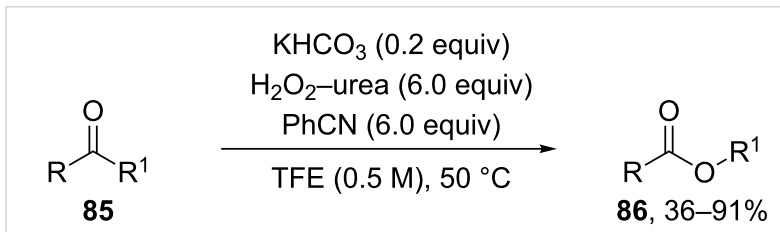

$\mathrm{R}, \mathrm{R}^{1}=$ cyclic ketones, adamantanone, tert-butyl methyl ketone

Scheme 28: Oxidation of ketones 85 to esters 86 with $\mathrm{H}_{2} \mathrm{O}_{2}$-urea in the presence of $\mathrm{KHCO}_{3}$.

either isolated enzymes or living whole cells are applied for the oxidative production of valuable intermediates [264-269].

The asymmetric oxidation of 3-substituted cyclopentane-1,2diones $\mathbf{8 7} \mathbf{a}-\mathbf{f}$ is an efficient tool in organic synthesis for the preparation of unsymmetrical $\gamma$-lactone acids $88 \mathbf{a}-\mathbf{f}$ with high optical purity and good yields (Table 6). These $\gamma$-lactone acids are valuable substrates for the synthesis of compounds with potentially useful pharmacological properties, such as homocitrates, alkyl- and aryl-substituted nucleosides [270-272].

The reaction starts with an asymmetric epoxidation of the substituted cyclopentane-1,2-dione 87a to form epoxide 89a. The second step involves the Baeyer-Villiger oxidation of epoxide 89a to peroxide 90a followed by the rearrangement into intermediate 91a. The latter is hydrolyzed by $\mathrm{H}_{2} \mathrm{O}$ to form dicarboxylic acid 92a, which is cyclized under the acidic conditions to $\gamma$-lactone acid 88a (Scheme 29) [270].

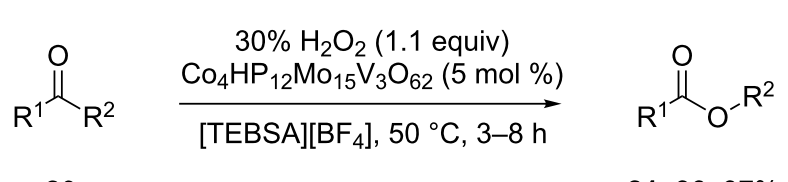

$$
\begin{aligned}
& 80 \\
& 81,86-97 \% \\
& \mathrm{R}^{1}=\text { aryl, alkyl } \\
& \mathrm{R}^{2}=\mathrm{H} \text {, aryl, alkyl }
\end{aligned}
$$

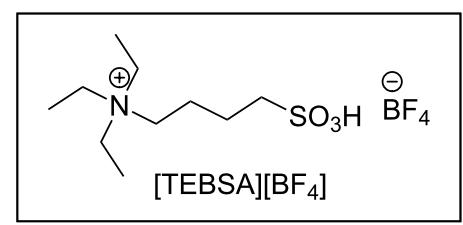

Scheme 26: The oxidation of aldehydes and ketones 80 by $\mathrm{H}_{2} \mathrm{O}_{2}$ catalyzed by $\mathrm{Co}_{4} \mathrm{HP}_{2} \mathrm{Mo}_{15} \mathrm{~V}_{3} \mathrm{O}_{62}$.

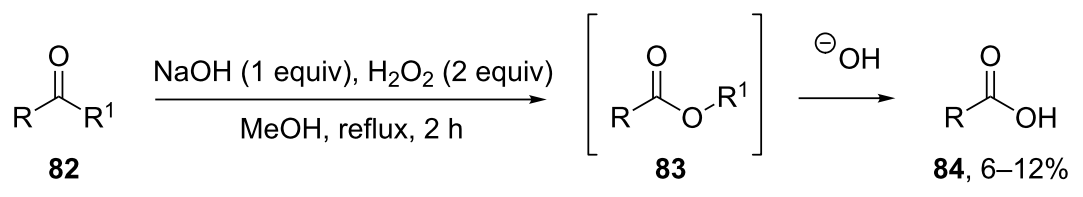

$\mathrm{R}=\mathrm{Ph}, \mathrm{CH}_{3}, \mathrm{C}_{3} \mathrm{H}_{7}$

$\mathrm{R}^{1}=\mathrm{C}_{3} \mathrm{H}_{7}, \mathrm{C}_{6} \mathrm{H}_{13}, \mathrm{iPr}$ 
Table 6: Asymmetric oxidation of 3-substituted cyclopentane-1,2diones 87a-f with the $\mathrm{Ti}(\mathrm{O}-\mathrm{iPr})_{4} /(+) \mathrm{DET} / t-\mathrm{BuOOH}$ system.

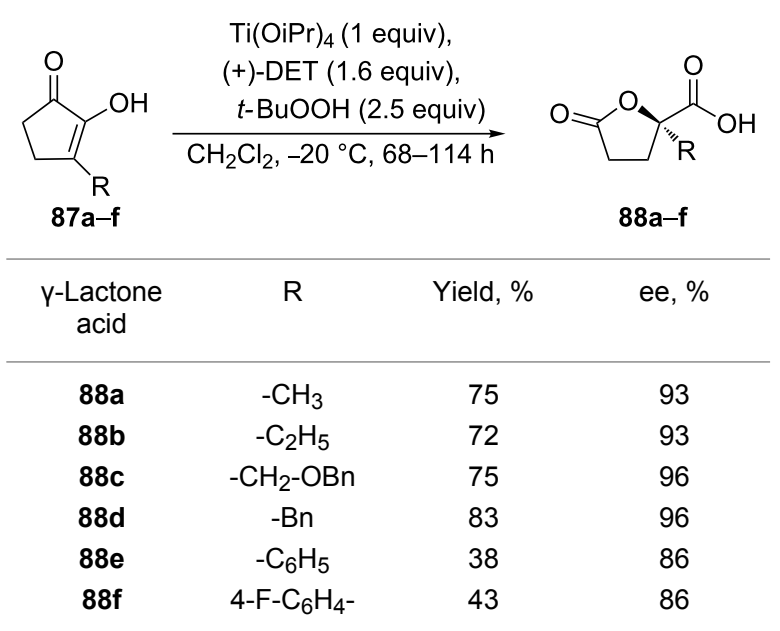

In most cases, the Baeyer-Villiger oxidation is a stereospecific and regioselective process with retention of the configuration. The oxidation of cis-4-tert-butyl-2-fluorocyclohexanone (93) with $m$-chloroperbenzoic acid in the presence of $\mathrm{NaHCO}_{3}$ affords fluorolactones 94 and 95 in $91 \%$ and $9 \%$ yields, respectively (Scheme 30) [273].

However, in order to perform the asymmetric oxidation of 3-substituted cyclobutanones $\mathbf{9 6 a}-\mathbf{f}$ to the corresponding lactones 97a-f (Table 7) [274], it is necessary to employ chiral Brønsted acids [274-277], organocatalysts [278,279] or en-

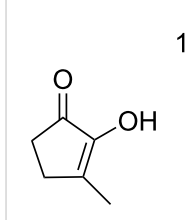

$87 a$

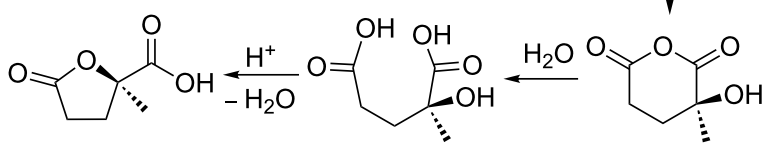

$88 a$

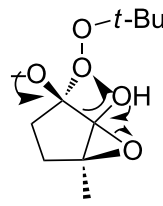

$90 a$

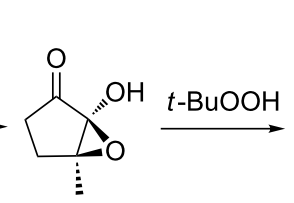

$89 a$

$92 a$
Scheme 29: Mechanism of the asymmetric oxidation of cyclopentane1,2-dione 87a with the $\mathrm{Ti}(\mathrm{OiPr})_{4} /(+) \mathrm{DET} / t$ - $\mathrm{BuOOH}$ system.

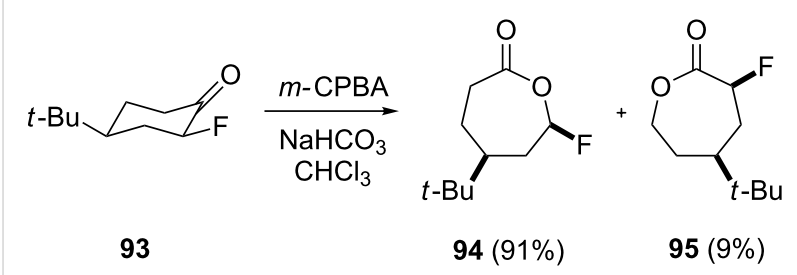

Scheme 30: The oxidation of cis-4-tert-butyl-2-fluorocyclohexanone (93) with $m$-chloroperbenzoic acid.

zymes [280-282] as the catalyst. The obtained asymmetric oxidation products can be used in the multistep synthesis of new biologically active compounds.

Table 7: Asymmetric oxidation of 3-substituted cyclobutanones $\mathbf{9 6 a - f .}$
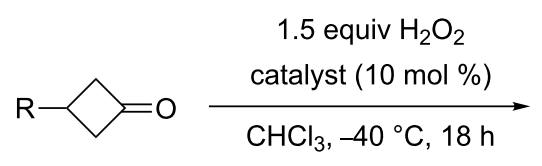

$96 a-f$<smiles>[R]C1COC(=O)C1</smiles>

97a-f

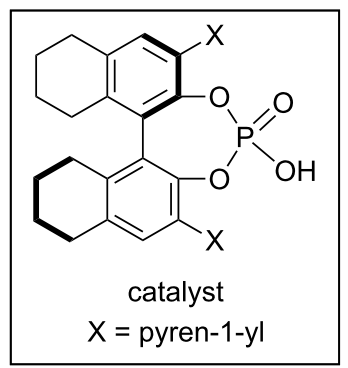

\begin{tabular}{|c|c|c|c|}
\hline Ketone & $\mathrm{R}$ & Yield, \% & ee, $\%$ (conf.) \\
\hline $96 a$ & $\mathrm{C}_{6} \mathrm{H}_{5}$ & 99 & $88(R)$ \\
\hline $96 b$ & $4-\mathrm{MeC}_{6} \mathrm{H}_{4}$ & 99 & $93(R)$ \\
\hline $96 c$ & $4-\mathrm{FC}_{6} \mathrm{H}_{4}$ & 99 & $84(R)$ \\
\hline $96 d$ & 2-naphthyl & 91 & $86(R)$ \\
\hline $96 e$ & $\mathrm{C}_{6} \mathrm{H}_{5} \mathrm{CH}_{2}$ & 99 & $58(S)$ \\
\hline $96 f$ & 4- $\mathrm{MeOC}_{6} \mathrm{H}_{4} \mathrm{CH}_{2}$ & 99 & $57(S)$ \\
\hline
\end{tabular}


Possible mechanisms for the asymmetric oxidation of 3-substituted cyclobutanone 96a with $\mathrm{H}_{2} \mathrm{O}_{2}$ catalyzed by chiral phosphoric acid are presented in Scheme 31 [275].

A number of optically active $\varepsilon$ - and $\gamma$-lactones $\mathbf{9 9}, \mathbf{1 0 0}$ was prepared by the enantioselective Baeyer-Villiger oxidation of racemic cyclic ketones 98 in up to $99 \%$ yield and $95 \%$ ee using the chiral $N, N^{\prime}$-dioxide-Sc(III) complex as catalyst (Scheme 32 ) [283].

In another work, a chiral $N, N^{\prime}$-dioxide-Sc(III) complex promoted Baeyer-Villiger oxidation was applied as instrument

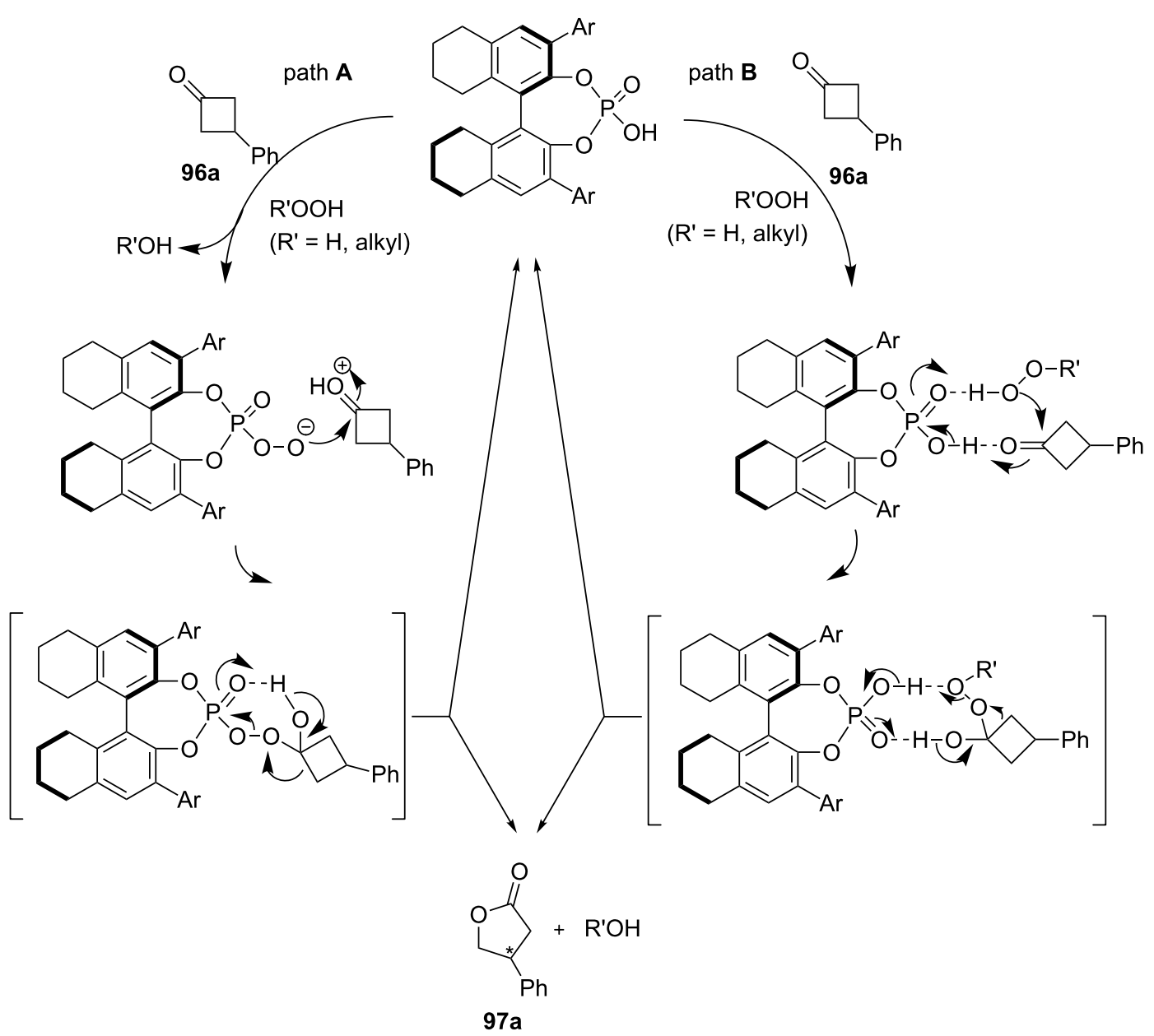

Scheme 31: The mechanism of the asymmetric oxidation of 3-substituted cyclobutanone $96 \mathrm{a}$ in the presence of chiral phosphoric acid.

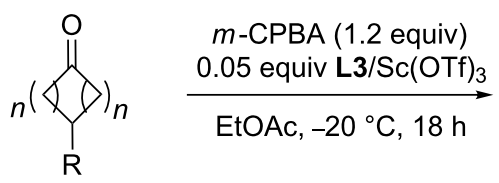

98<smiles>[R]C(=[IH])C1COC(=O)C1</smiles>

99<smiles>[R][C@H]1CCOC(=O)CC1</smiles>

100

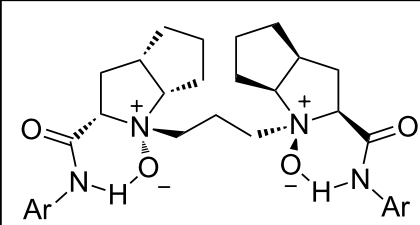

L3: $\mathrm{Ar}=2,4,6-\mathrm{iPr}_{3} \mathrm{C}_{6} \mathrm{H}_{2}$

$\mathrm{R}=$ alkyl, aryl

24 examples

yield: $71-99 \%$

ee: $80-95 \%$

Scheme 32: Enantioselective Baeyer-Villiger oxidation of cyclic ketones 98. 
for a kinetic resolution of racemic 2-substituted cyclopentanones with formation of the 6 -substituted $\delta$-lactones in up to $98 \%$ ee and $>95 \%$ regioselectivity [284].

A highly regio- and enantioselective Baeyer-Villiger oxidation of cyclic ketones $\mathbf{1 0 1}$ bearing amido, ureido, or sulfonamido functional groups to lactones $\mathbf{1 0 2}$ and $\mathbf{1 0 3}$ was carried out using the peptide-based catalyst 104. Hydrogen-bonding interactions are responsible for both types of selectivity. Notably, a reversal of the typically seen selectivity was observed with the peptide catalyst (Scheme 33) [285].

Versatility of the Baeyer-Villiger reaction with respect to starting reactants: The Baeyer-Villiger reaction cannot only be performed with ketones but also with acetals and aldimines as the starting substrates. The oxidation of cycloalkanone acetals $\mathbf{1 0 5} \mathbf{a}-\mathbf{g}$ with performic acid generated in situ provides a new route to dicarboxylic acids $\mathbf{1 0 6} \mathbf{a}-\mathbf{g}$ and hydroxycarboxylic acids 107a-g (Table 8) [286].

The proposed mechanism of the oxidation of acetal $\mathbf{1 0 5 f}$ is shown in Scheme 34.

In the first step of the reaction, the elimination of methanol from $\mathbf{1 0 5 f}$ and formation of $\mathbf{1 0 8}$ takes place. Probably perester $\mathbf{1 0 9}$ is formed alongside of $\mathbf{1 0 8}$. After formation of $\mathbf{1 0 9}$, the reaction proceeds by two different routes $\mathbf{A}$ and $\mathbf{B}$ (second stage). The first route $\mathbf{A}$ leads to formation of epoxide 110,<smiles>[R]NC1CCCC(=O)C1[R]</smiles>

\begin{tabular}{|c|c|c|}
\hline A) $m$-CPBA (1.1 equiv), $\mathrm{CH}_{2} \mathrm{Cl}_{2}, 21^{\circ} \mathrm{C}, 12 \mathrm{~h}$ & $1.4-100$ & 1 \\
\hline $\begin{array}{l}\text { B) catalyst ( } 10 \mathrm{~mol} \%) \text {, DMAP ( } 10 \mathrm{~mol} \% \text { ), } \\
\text { DIC ( } 3 \text { equiv), } \mathrm{H}_{2} \mathrm{O}_{2} \text { ( } 3.8 \text { equiv), } \mathrm{CHCl}_{3} \text {, } \\
21^{\circ} \mathrm{C}, 12 \mathrm{~h}\end{array}$ & $\begin{array}{c}1 \\
\text { up to } 93: 7 \text { er }\end{array}$ & $\begin{array}{c}: \quad 4.3-100 \\
\text { up to } 99: 1 \text { er }\end{array}$ \\
\hline
\end{tabular}

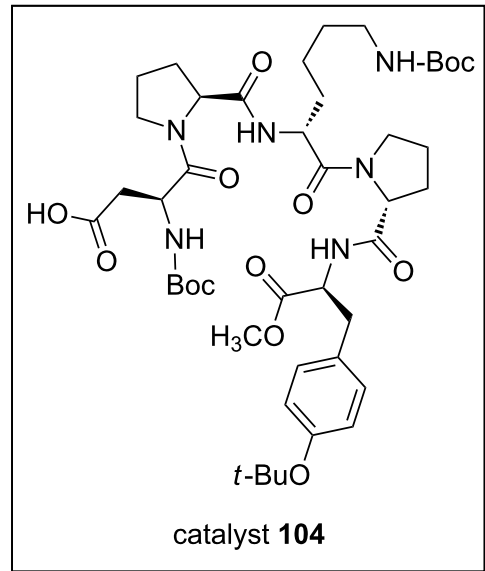

Scheme 33: Regio- and enantioselective Baeyer-Villiger oxidation of cyclic ketones 101.

$$
\begin{aligned}
& \text { Table 8: Oxidation of cycloalkanone acetals } 105 \mathrm{a}-\mathrm{g} \\
& \frac{\mathrm{H}_{2} \mathrm{O}_{2}, \mathrm{HCOOH}}{\mathrm{H}_{2} \mathrm{SO}_{4}}
\end{aligned}
$$

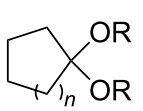

\begin{tabular}{|c|c|c|c|c|}
\hline \multirow[t]{2}{*}{ Ketal } & \multicolumn{2}{|c|}{$\mathrm{H}_{2} \mathrm{O}_{2}$ (6\% ethereal solution) } & \multicolumn{2}{|c|}{$\mathrm{H}_{2} \mathrm{O}_{2}$ (30\% aqueous solution) } \\
\hline & Yield of $106, \%$ & Yield of $107, \%$ & Yield of $106, \%$ & Yield of $107, \%$ \\
\hline $105 a$ & 14 & 51 & 11 & 61 \\
\hline $105 b$ & 6 & 68 & traces & 61 \\
\hline $105 c$ & 63 & 15 & 44 & 17 \\
\hline $105 d$ & 77 & 16 & 57 & 21 \\
\hline $105 e$ & 74 & 14 & 69 & 21 \\
\hline $105 f$ & 62 & 22 & 72 & 15 \\
\hline $105 \mathrm{~g}$ & 72 & 19 & 65 & 23 \\
\hline
\end{tabular}




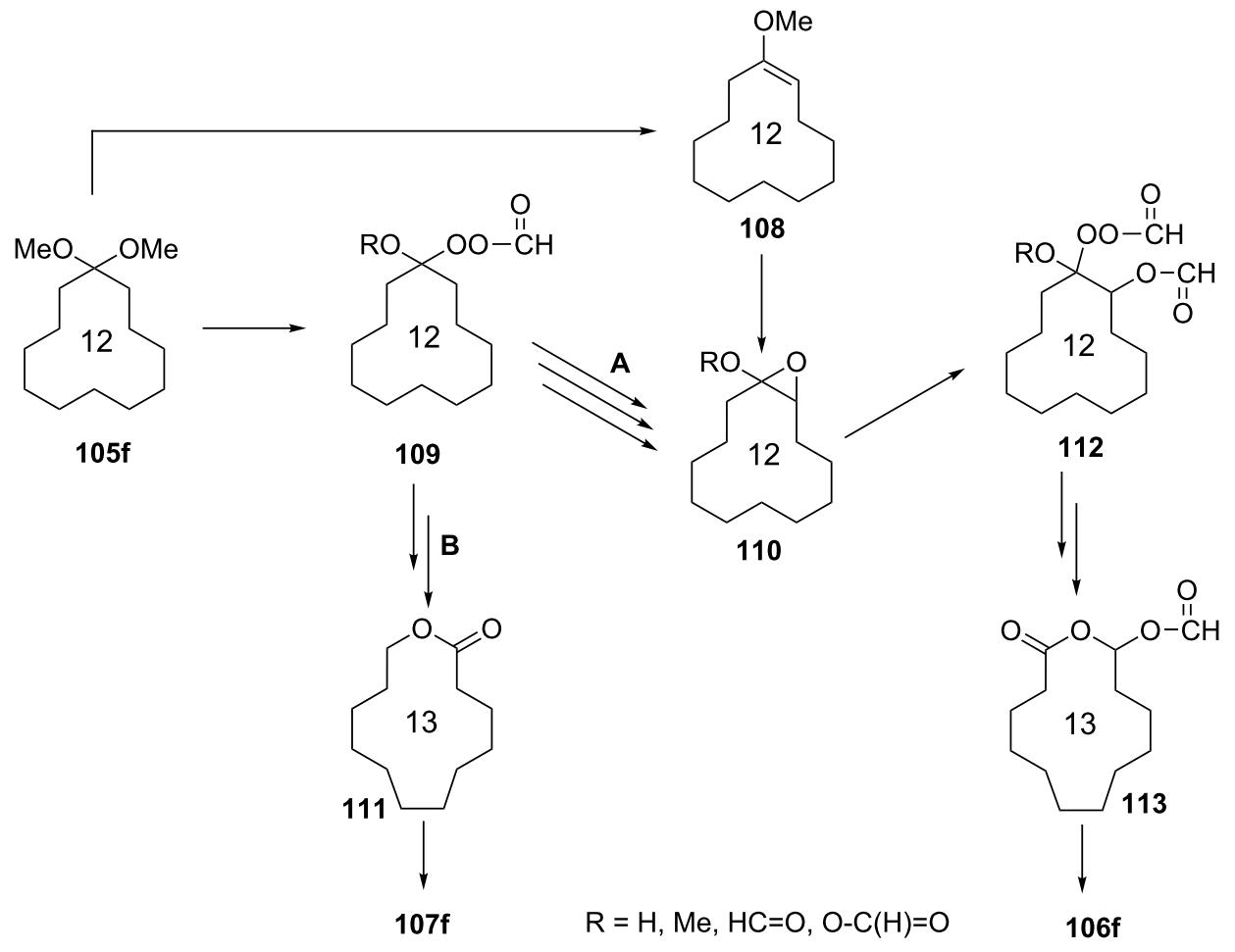

Scheme 34: The proposed mechanism of the Baeyer-Villiger oxidation of acetal $105 \mathrm{f}$.

whereas the second route (B) proceeds through the Baeyer-Villiger reaction with formation of lactone $\mathbf{1 1 1}$ and subsequent acid hydrolysis to give $\mathbf{1 0 7 f}$. At the third stage (route $\mathbf{A}$ ), ether $\mathbf{1 1 2}$ is formed from $\mathbf{1 1 0}$ and subsequently rearranged by a Baeyer-Villiger reaction into $\mathbf{1 1 3}$, which is oxidized to form $\mathbf{1 0 6 f}$.

This method can be applied to the synthesis of dodecanedioic acid, which is used in anticorrosive composites, polyester and polyamide threads, and lubricants, for the synthesis of tridecanedioic acid, and as a component of perfume formulations.

Scheme 35 presents the synthesis of hydroxy- $10 H$-acridin-9-one 117 starting from tetramethoxyanthracene 114 through the formation of peroxide 115, which rearranges through an acid-cata- lyzed Baeyer-Villiger-type rearrangement into 116. Hydroxy$10 \mathrm{H}$-acridin-9-ones 117 proved to be promising antipsoriatic agents [287].

The oxidation of aldimines 118a-f with $m$-chloroperbenzoic acid in the presence of boron trifluoride etherate produces amides 119a-f in good yields (Table 9). The products of this transformation are strongly dependent on the electronic properties of the aromatic substituents at the carbon atom of the aldimines [288]. In the case of electron-donating substituents on the aryl fragment (Ar), formamides $119 \mathbf{a}-\mathbf{c}$ are obtained as the result of imine oxidation and aryl migration. On the other hand, electron-withdrawing substituents on the aryl group (Ar) promote the formation of amides $\mathbf{1 1 9 d - f}$ as result of hydride migration.

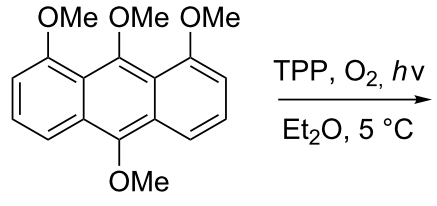

114

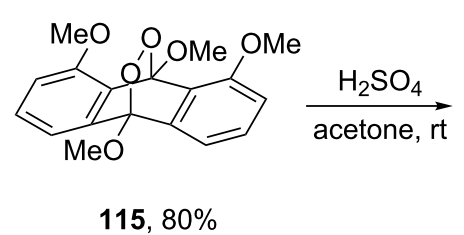

$115,80 \%$<smiles>COc1cccc(OC)c1C(=O)c1c(OC)cccc1C(C)=O</smiles>

$116,72 \%$<smiles>C#CC#CC#CC</smiles>

117 
Table 9: Oxidation of aldimines $118 \mathrm{a}-\mathrm{f}$ to amides by $m-\mathrm{CPBA}-\mathrm{BF}_{3} \cdot \mathrm{Et}_{2} \mathrm{O}$ system.

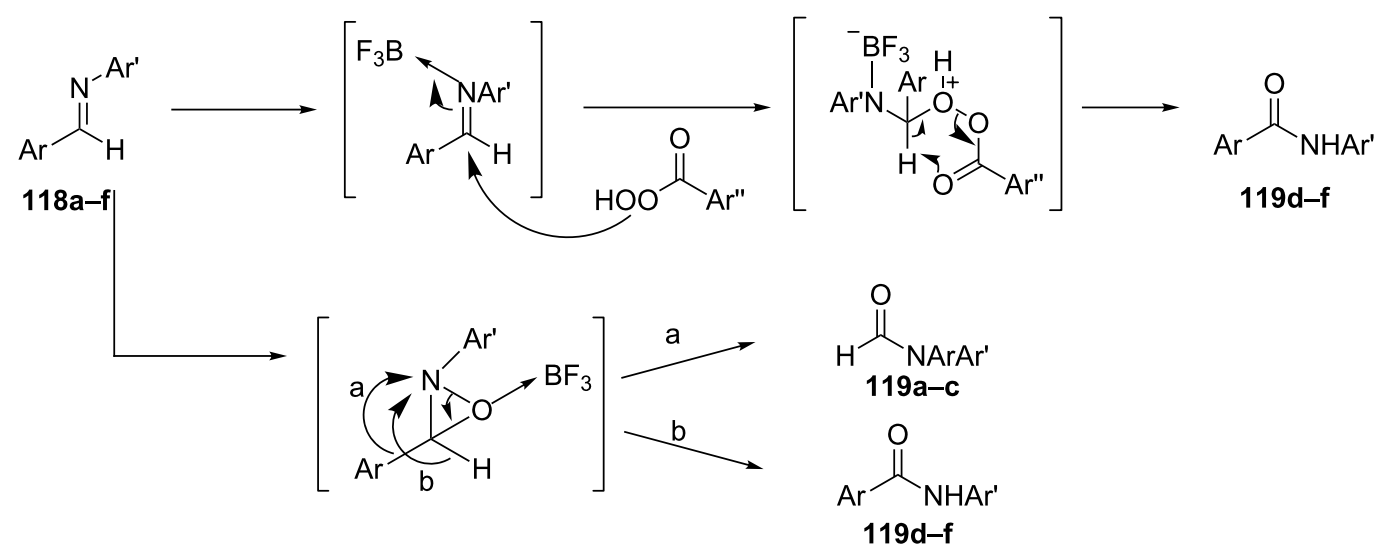

\begin{tabular}{|c|c|c|c|}
\hline Compound & Imine & Product & Yield, \% \\
\hline $118 a$ & $\mathrm{C}_{6} \mathrm{H}_{5} \mathrm{CH}=\mathrm{NC}_{6} \mathrm{H}_{5}$ & $\operatorname{HCON}\left(\mathrm{C}_{6} \mathrm{H}_{5}\right)_{2}$ & 82 \\
\hline $118 b$ & $p-\mathrm{Me}-\mathrm{C}_{6} \mathrm{H}_{4} \mathrm{CH}=\mathrm{NC}_{6} \mathrm{H}_{5}$ & $\mathrm{HCONC}_{6} \mathrm{H}_{5} p-\mathrm{Me}-\mathrm{C}_{6} \mathrm{H}_{4}$ & 90 \\
\hline $118 c$ & $p-\mathrm{MeO}-\mathrm{C}_{6} \mathrm{H}_{4} \mathrm{CH}=\mathrm{NC}_{6} \mathrm{H}_{5}$ & $\mathrm{HCONC}_{6} \mathrm{H}_{5} p-\mathrm{MeO}-\mathrm{C}_{6} \mathrm{H}_{4}$ & 91 \\
\hline $118 d$ & $p-\mathrm{NO}_{2}-\mathrm{C}_{6} \mathrm{H}_{4} \mathrm{CH}=\mathrm{NC}_{6} \mathrm{H}_{5}$ & $p-\mathrm{NO}_{2}-\mathrm{C}_{6} \mathrm{H}_{4} \mathrm{CONHC}_{6} \mathrm{H}_{5}$ & 71 \\
\hline $118 e$ & $p-\mathrm{NC}-\mathrm{C}_{6} \mathrm{H}_{4} \mathrm{CH}=\mathrm{NC}_{6} \mathrm{H}_{5}$ & $p-\mathrm{NC}-\mathrm{C}_{6} \mathrm{H}_{4} \mathrm{CONHC}_{6} \mathrm{H}_{5}$ & 79 \\
\hline $118 f$ & $p-\mathrm{F}_{3} \mathrm{C}-\mathrm{C}_{6} \mathrm{H}_{4} \mathrm{CH}=\mathrm{NC}_{6} \mathrm{H}_{5}$ & $p-\mathrm{F}_{3} \mathrm{C}-\mathrm{C}_{6} \mathrm{H}_{4} \mathrm{CONHC}_{6} \mathrm{H}_{5}$ & 75 \\
\hline
\end{tabular}

The sterically hindered and fully substituted pyrrole $\mathbf{1 2 0}$ underwent a Baeyer-Villiger reaction to yield a 4,5-dihydro- $1 \mathrm{H}$ ketopyrrole 121 (Scheme 36) [289].<smiles>CCOC(=O)c1c(C=O)c(C(C)(C)C)n(Cc2ccccc2)c1C(C)(C)C</smiles>

120

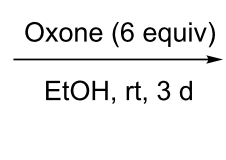<smiles>CCOC(=O)C1=C(C(C)(C)C)NC2(OC(C)C)C1C(=O)C2(C)C</smiles>

$121,48 \%$
Scheme 36: The Baeyer-Villiger oxidation of the fully substituted pyrrole 120.

\subsection{Criegee rearrangement}

The Criegee rearrangement involves the transformation of a peroxide, mainly peroxyesters $\mathbf{B}$, into carbonates, esters, or ketones $\mathbf{C}$ and alcohols $\mathbf{D}$ through an oxygen insertion or consecutive oxygen insertions. The peroxyester $\mathbf{B}$ is initially prepared from a tertiary alcohol $\mathbf{A}$ and a peracid. In addition, the peroxy ester can also be prepared via the reaction of a ketone and a peracid (i.e., through a Baeyer-Villiger oxidation); the additional product of peracid to ketone is often referred to as the Criegee intermediate. From this point of view, the Baeyer-Villiger oxidation is a subset of the Criegee rearrangement (Scheme 37) [290].

As mentioned above the Criegee reaction and the Baeyer-Villiger oxidation are related processes and both reactions involve the formation of the Criegee intermediate. The distinguishing feature of the Criegee rearrangement is that the Criegee intermediate rearranges into a carbocation. The mechanism of the Criegee reaction is presented in Scheme 38.

Initially the reaction of the peracid with the tertiary alcohol 122 produces perester (Criegee intermediate) 123. One alkyl substituent migrates from the carbon atom to the adjacent oxygen atom and replaces the carboxylic acid moiety to form carbocat-

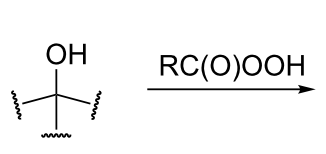

A<smiles>[R]C(=O)OC1(CC)CCCC1</smiles>

B<smiles>[R]C(=O)O</smiles>

D

Scheme 37: The Criegee rearrangement. 


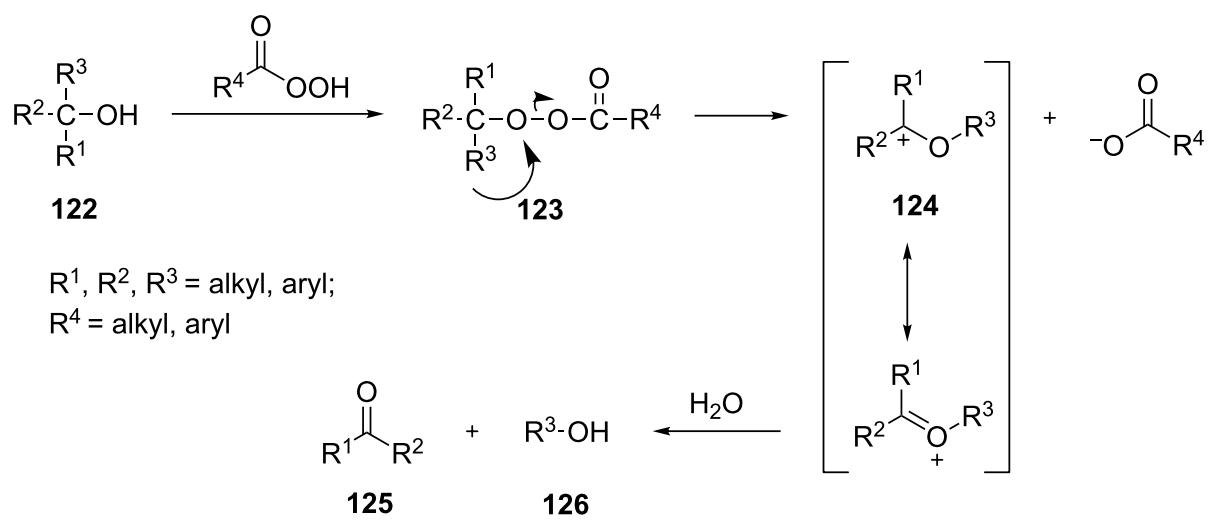

Scheme 38: The mechanism of the Criegee reaction of a peracid with a tertiary alcohol 122.

ion 124. Then, the addition of water to carbocation 124 affords ketone $\mathbf{1 2 5}$ and alcohol 126. $p$-Nitroperbenzoic acid is usually used to oxidize tertiary alcohols because the anion of this acid is a good leaving group.

The Criegee rearrangement was discovered in 1944 in the reaction of decaline ethylperoxoate $\mathbf{1 2 7}$ that rearranged into isomeric ester ketal 128 (Scheme 39) [291].<smiles>CCCCC1CCCCC1(O)OC(C)=O</smiles>

127

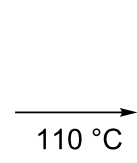<smiles>CC(=O)OC12CCCCC1CCCC2</smiles>

128
Scheme 39: Criegee rearrangement of decaline ethylperoxoate 127 into ketal 128.
The mechanism of the Criegee rearrangement was studied using 2-alkoxy-2-propyl per-4-nitrobenzoates [292]. It was shown that the ionic cleavage of 2-methoxy-2-propyl perester 129 to $p$-nitrobenzoic acid (132), methyl acetate (133) and dimethyl ether (134) occurred through transition state $\mathbf{1 3 0}$ with generation of dimethoxycarbonium ion 131 (Scheme 40).

Investigations using aromatic peroxy esters 129 demonstrated that the migratory ability of the migrating group $\mathrm{R}$ decreases in the series $t$ - $\mathrm{Bu}>\mathrm{C}_{6} \mathrm{H}_{5}>\mathrm{iPr}>\mathrm{OEt}>\mathrm{OMe}>\mathrm{Et}>\mathrm{Me}$ [293,294].

The Criegee rearrangement of $\alpha$-methoxy hydroperoxide $\mathbf{1 3 6}$ obtained from (+)-trans-dihydrocarvone 135 produces trans-5acetoxy-2-methylcyclohexanone 137 and intermediate peroxyacetate 138 (Scheme 41) [295].

Later on, the Criegee rearrangement was extended [296] to peroxides 139, 142, and 145 which made it possible to selec-<smiles>[R]C(C)(C)OOC(=O)c1ccc([N+](=O)[O-])cc1</smiles>

129, $\mathrm{R}=\mathrm{OMe}$<smiles>CC(=O)OOC(=O)c1ccc([N+](=O)[O-])cc1</smiles>

130

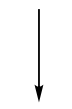<smiles>COC(=O)[C@@H](OC)OC(=O)c1ccc([N+](=O)[O-])cc1</smiles>

Scheme 40: The ionic cleavage of 2-methoxy-2-propyl perester 129. 


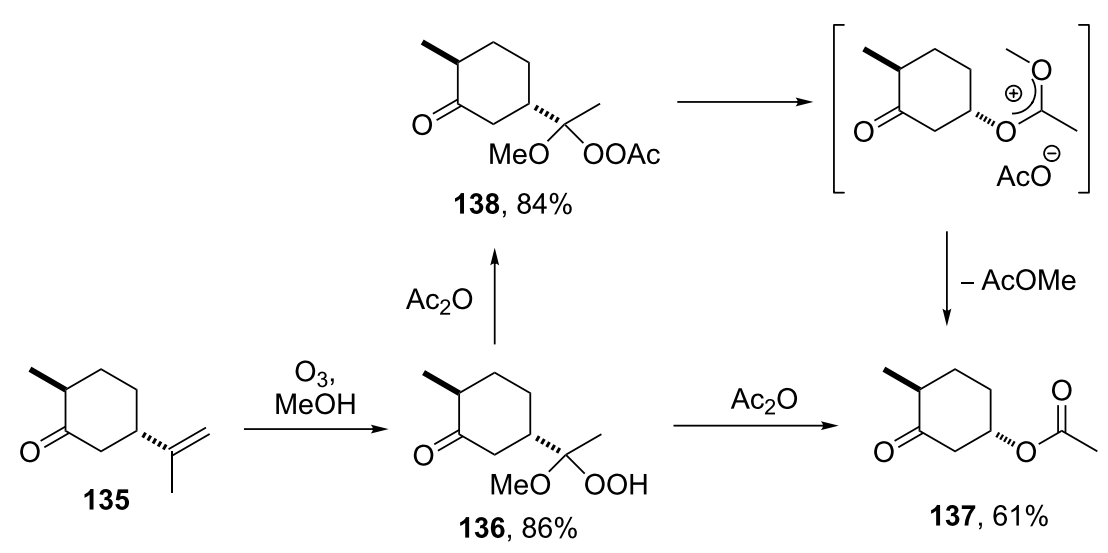

Scheme 41: The Criegee rearrangement of $\alpha$-methoxy hydroperoxide 136.

tively synthesize both cyclic 140, 141, 144 and acyclic enol esters 146 and acetal 143 (Scheme 42).<smiles>[X]C(=O)OOC1CCCC1[R]</smiles>

139

$n=1-6$

$\mathrm{R}=\mathrm{H}, \mathrm{SnBu}_{3}, \mathrm{SiMe}_{3}$

$\mathrm{X}=\mathrm{Me}, \mathrm{iPr}, \mathrm{CF}_{3}$, NHTs<smiles>[X]C(=O)OOC1CCCc2ccccc21</smiles>

142

$\mathrm{X}=\mathrm{CF}_{3}, \mathrm{NHTs}$<smiles>[X]C(=O)OOC(C=CCCCCCC)OOC</smiles><smiles>[3H]I</smiles>

\section{5}<smiles>[X]C(=O)OC1CCCc2ccccc2O1</smiles>

144

143

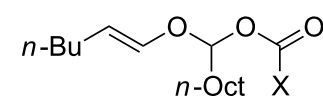

146
Scheme 42: Synthesis of enol esters and acetals via the Criegee rearrangement.

The Criegee rearrangement of 1-hydroperoxy-2-oxabicycloalkanes $147 \mathbf{a}-\mathbf{d}$ in formic or acetic acid containing catalytic amounts of sulfuric acid affords $\omega$-alkoxy-( $\omega$-3)-hydroxyalkanoic acid lactones 148a-d and 149a-d (Table 10) [297].
The transformation of 1-hydroperoxy-2-oxabicycloalkanones 147a-d into $\omega$-alkoxy-( $\omega-3)$-hydroxyalkanoic acid lactones $148 \mathbf{a}-\mathbf{d}$ and $149 \mathbf{a}-\mathbf{d}$ is proposed to occur through intermediate peroxy ester 150 (Scheme 43).

1,2-Dioxolanes and related cyclic systems have attracted considerable attention from synthetic chemists as they may be used for the preparation of biologically active compounds. Under acidic conditions, 3-hydroxy-1,2-dioxolanes $\mathbf{1 5 1}$ are rearranged similarly to the Criegee mechanism into diketone derivatives 152 (Scheme 44) [298].

Unlike the Baeyer-Villiger rearrangement, in which only mono$\mathrm{O}$-insertion can take place, the Criegee rearrangement of peroxide $\mathbf{1 5 3}$ in an acidic medium and under solvent-free conditions does not have such limitations. Thus, the latter reaction can proceed sequentially through the mono-, di-, and tri-Oinsertion steps with formation of ketone 154, ester 155 and carbonate ester 156 (Scheme 45) [299,300].

The selective double Criegee rearrangement next to a tertiary carbon was shown in the oxidative fragmentation at the bridgehead position of adamantanes $157 \mathbf{a}, \mathbf{b}$. The reaction employed the trifluoroperacetic acid (TFPAA)/trifluoroacetic acid (TFAA) system and afforded compounds $\mathbf{1 5 8 a}, \mathbf{b}$ in high yields (Scheme 46) [300].

This method for the insertion of an oxygen atom was applied to the oxidation of triarylmethanols 159a-d [299]. The successive insertion of oxygen atoms gave rise to diaryl carbonates $160 a-d$ in good yields (Scheme 47).

In the last years, new enantiospecific approaches for the synthesis of sesquiterpenes $\mathbf{1 6 2}$ from ketone $\mathbf{1 6 1}$ were developed [301-307]. In these methods, the Criegee rearrangement repre- 
Table 10: Synthesis of $\omega$-alkoxy-( $\omega$-3)-hydroxyalkanoic acid lactones 148a-d and 149a-d from 1-hydroperoxy-2-oxabicycloalkanones 147 a-d.

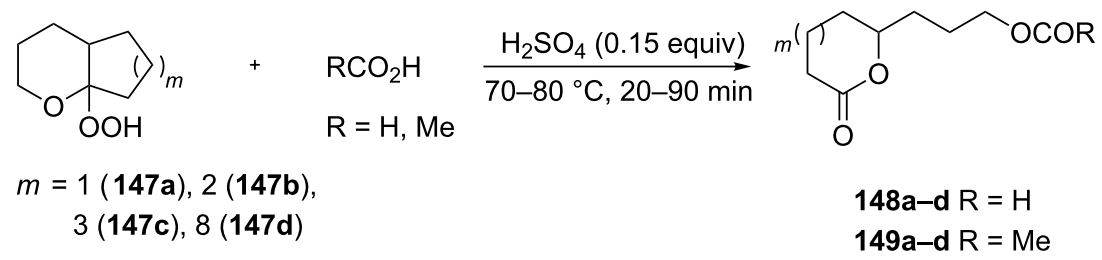

\begin{tabular}{|c|c|c|c|c|}
\hline Substrate & $\mathrm{RCOOH}$ & Time $(\min )$ & Lactone & Yield, \% \\
\hline $147 a$ & $\mathrm{HCOOH}$ & 20 & $148 a$ & 64 \\
\hline $147 a$ & $\mathrm{AcOH}$ & 20 & $149 a$ & 65 \\
\hline $147 b$ & $\mathrm{HCOOH}$ & 20 & $148 b$ & 68 \\
\hline $147 b$ & $\mathrm{AcOH}$ & 20 & $149 b$ & 70 \\
\hline $147 c$ & $\mathrm{HCOOH}$ & 30 & $148 c$ & 57 \\
\hline $147 c$ & $\mathrm{AcOH}$ & 30 & $149 c$ & 65 \\
\hline $147 d$ & $\mathrm{HCOOH}$ & 90 & $148 d$ & 68 \\
\hline $147 d$ & $\mathrm{AcOH}$ & 90 & $149 d$ & 53 \\
\hline
\end{tabular}

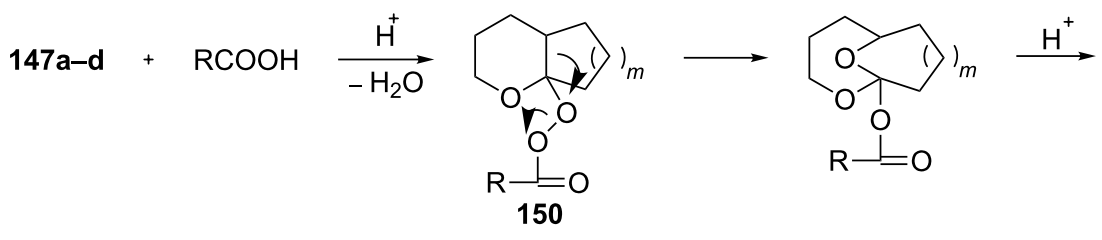

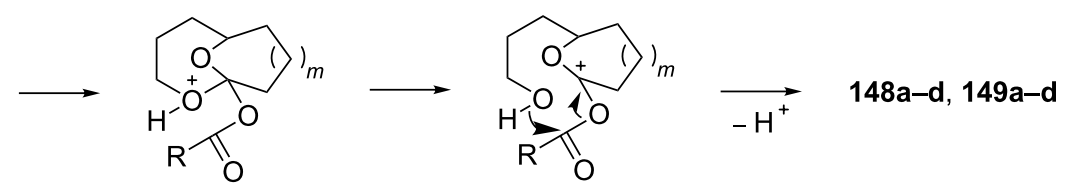

Scheme 43: Proposed mechanism of the transformation of 1-hydroperoxy-2-oxabicycloalkanones 147a-d.

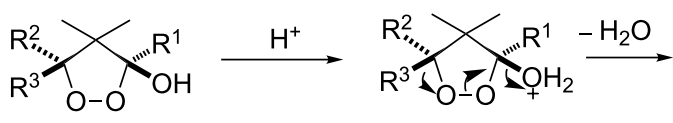

151a-c

$$
\begin{aligned}
& \underset{\mathrm{R}^{3-\mathrm{O}^{+}}}{\mathrm{R}^{2} \prod_{\mathrm{O}}} \stackrel{\mathrm{R}^{1}}{+\mathrm{H}_{2} \mathrm{O}} \mathrm{R}^{3} \mathrm{OH}+\prod_{\mathrm{O}}^{\mathrm{R}_{152 a-c}^{2}} \prod_{\mathrm{O}}^{\mathrm{R}^{1}} \\
& \text { a: } R^{1}=R^{2}=M e ; R^{3}=P h \\
& \text { 92-100\% } \\
& \text { b: } R^{1}=R^{2}=R^{3}=P h \\
& \text { c: } R^{1}=P h ; R^{2}=R^{3}=M e
\end{aligned}
$$

Scheme 44: Transformation of 3-hydroxy-1,2-dioxolanes 151 into diketone derivatives 152 sents one key step and one example is presented in Scheme 48 [303].

A method for the large-scale synthesis of a trans-hydrindan derivatives 164, 165 related to vitamin $\mathrm{D}$, based on the Criegee rearrangement of alkene $\mathbf{1 6 3}$ was realized (Scheme 49) [308].

Carbonyl oxides (Criegee intermediates) are one of the most important compounds in tropospheric chemistry [309]. Direct investigations of formaldehyde oxide $\left(\mathrm{CH}_{2} \mathrm{OO}\right)$ or acetaldehyde oxide $\left(\mathrm{CH}_{3} \mathrm{CHOO}\right)$ reactions with water vapor, $\mathrm{SO}_{2}, \mathrm{NO}_{2}$ were carried out [310-312].

\subsection{Hock rearrangement}

The Hock rearrangement is a protic or Lewis acid-promoted rearrangement of hydroperoxides $\mathbf{A}$ resulting in a $\mathrm{C}-\mathrm{C}$ bond 


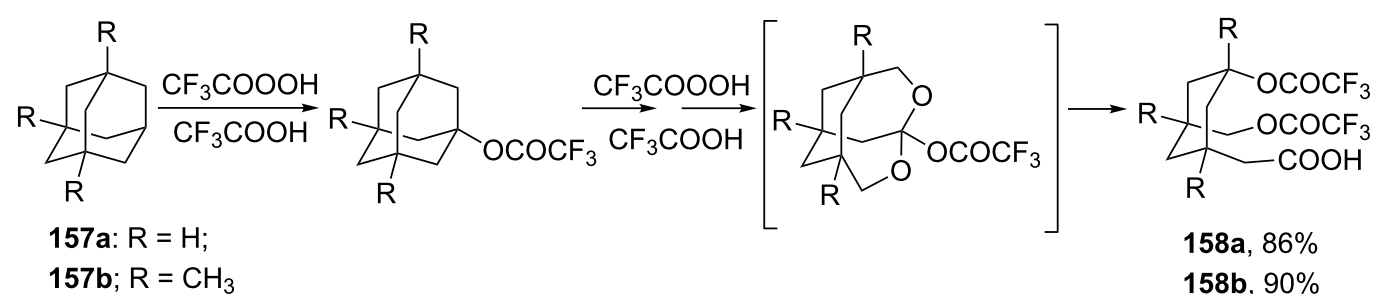

Scheme 46: The sequential Criegee rearrangements of adamantanes 157a,b.<smiles>[R]c1ccc(C(O)(c2ccc([R])cc2)c2ccc([R])cc2)cc1</smiles><smiles>[R]c1ccc(OC(=O)Oc2ccc([R])cc2)cc1</smiles>

160a: $96 \%$

160b: $91 \%$

160c: $90 \%$

160d: $92 \%$

Scheme 47: Synthesis of diaryl carbonates $160 a-d$ from triarylmethanols $159 a-d$ through successive oxygen insertion.

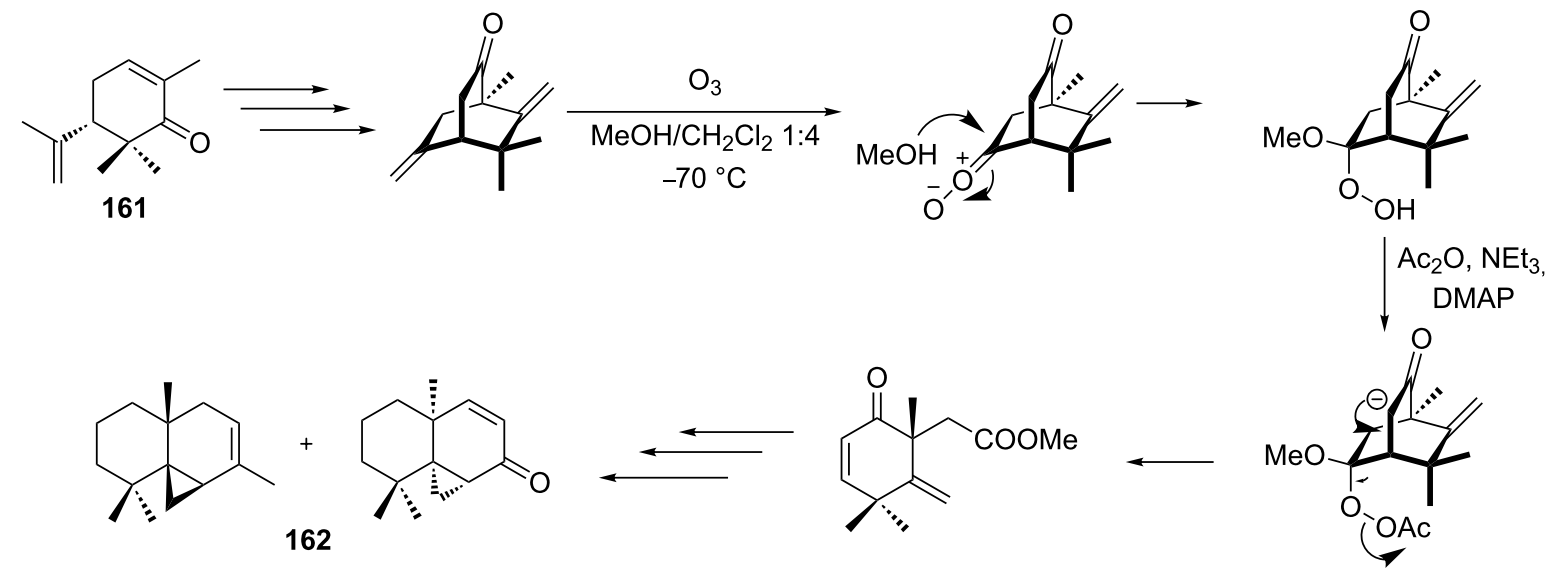

Scheme 48: The synthesis of sesquiterpenes 162 from ketone 161 with a Criegee rearrangement as one key step. 


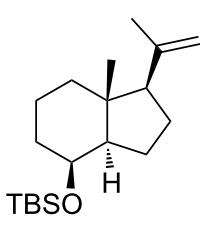

163
1. $\mathrm{O}_{3}, \mathrm{DCM} / \mathrm{MeOH} 6: 1,-78^{\circ} \mathrm{C}$

2. $\mathrm{Ac}_{2} \mathrm{O}$ (40 equiv), $\mathrm{Et}_{3} \mathrm{~N}$ (36 equiv), DMAP (cat. amount)

3. $\mathrm{K}_{2} \mathrm{CO}_{3}$ (5 equiv), $\mathrm{MeOH}$<smiles>CC1(C)CCCC2C(O)CCC21</smiles>

$164,80 \%$

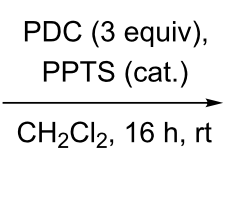<smiles>CC(C)[C@H]1CCCC2(C)C(=O)CCC12</smiles>

$165,85 \%$

Scheme 49: Synthesis of trans-hydrindan derivatives 164, 165.

cleavage to form alcohol $\mathbf{B}$ and carbonyl compound $\mathbf{C}$ (Scheme 50) [313].

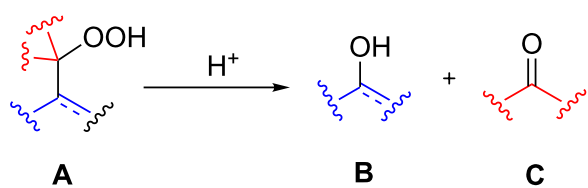

Scheme 50: The Hock rearrangement.

The Hock rearrangement is a key step in the cumene process, which is used for the industrial production of phenol (170) and acetone (171) from benzene (166) and propylene (167) in the presence of air and radical initiators. The cumene process was described by Udris and Sergeev in 1947 [314,315] and independently by Hock in 1944 [316,317]. The general scheme of the cumene process, involving the formation of cumene hydroperoxide is shown in Scheme 51.

The cumene process involves the acid-catalyzed rearrangement of cumene hydroperoxide (168) as a key step. The reaction starts with the protonation of the terminal oxygen atom of cumene hydroperoxide (168) followed by the migration of the phenyl group from the benzylic carbon atom to the peroxide oxygen atom and the elimination of a water molecule to form carbocation 169. The carbocation 169 is attacked by a water molecule, a proton is transferred to the oxygen atom attached to the phenyl group, and finally the cleavage of the adduct yields phenol (170) and acetone (171).

The Hock rearrangement of aliphatic hydroperoxides proceeds quite readily in concentrated $\mathrm{H}_{2} \mathrm{SO}_{4}$ [318] or superacids [319] (Scheme 52). This is associated with higher resistance of these compounds toward acid-catalyzed rearrangements compared with benzylic or allylic hydroperoxides. For example, aliphatic hydroperoxides are not cleaved in 5-50\% aqueous $\mathrm{H}_{2} \mathrm{SO}_{4}$ but on the contrary, these compounds are produced under these conditions. More efficient catalysts are the compounds $\mathrm{Sn}(\mathrm{OTf})_{2}$ and $\mathrm{La}(\mathrm{OTf})_{3}$ which can be used for the transformation of 2-hydroperoxy-2,4,4-trimethylpentane (172) into neopentyl alcohol (173) and acetone (171). The $\mathrm{Sn}(\mathrm{OTf})_{2}$ and $\mathrm{La}(\mathrm{OTf})_{3}$-catalyzed reaction afforded neopentyl alcohol (173) in 62 and $70 \%$ yield, respectively [320].

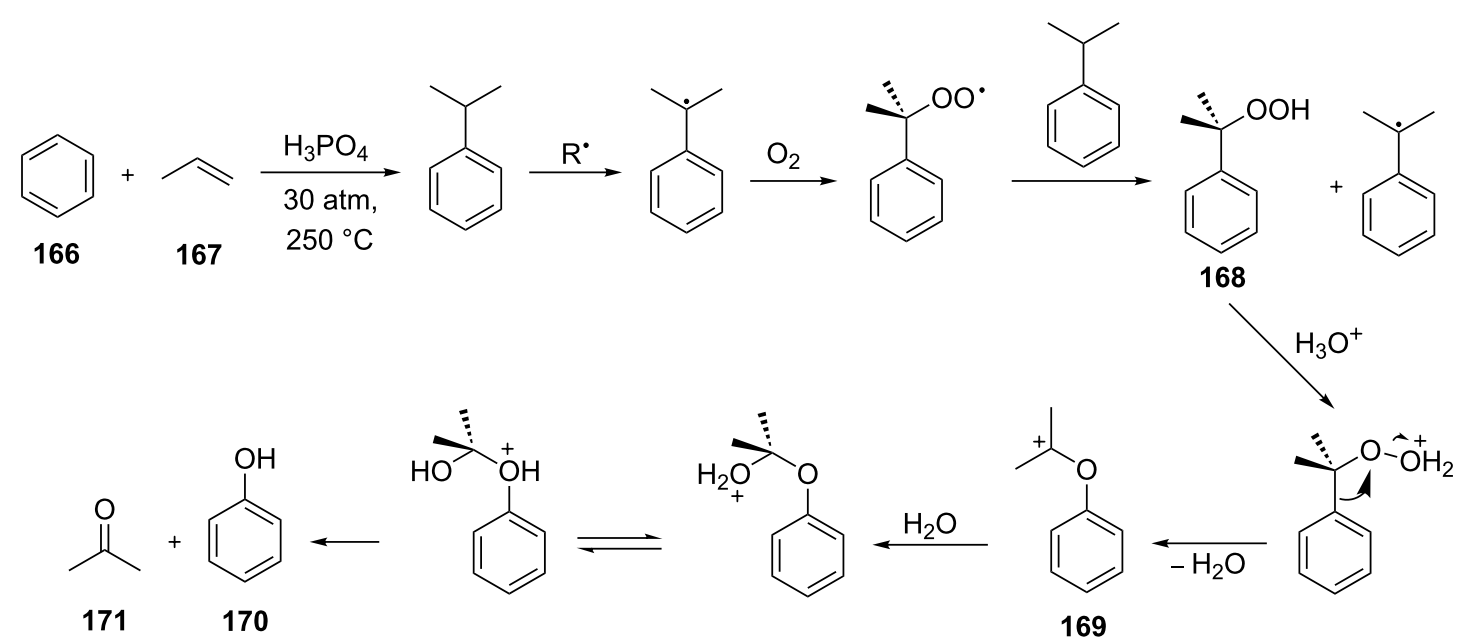




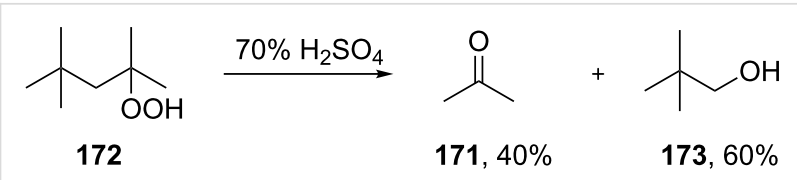

Scheme 52: The Hock rearrangement of aliphatic hydroperoxides.

The hydrogen peroxide promoted ring expansion for the synthesis of oxabicycles 176a-c was described for the first time in 1985 [321]. The reaction involved the solvolysis of homoallylic brosylates $174 \mathbf{a}-\mathbf{c}$ or spiro cyclopropyl carbinols $\mathbf{1 7 5 a}-\mathbf{c}$ in the $\mathrm{THF} / \mathrm{H}_{2} \mathrm{O}_{2}$ system, resulting in the increase in the ring size by two atoms and the formation of hydroperoxy oxabicyclo derivatives 176a-c (Table 11).

The mechanism of the solvolysis of $\mathbf{1 7 4}$ or $\mathbf{1 7 5}$ in the THF/ $\mathrm{H}_{2} \mathrm{O}_{2}$ system involves the formation of solvolytically generated cyclobutyl hydroperoxides $\mathbf{1 7 7}$ followed by the rearrangement of the latter into oxa-bridged, hydroperoxyhemiketals $\mathbf{1 7 6}$ (Scheme 53).

The fragmentation of hydroperoxy acetals $\mathbf{1 7 8 a}-\mathbf{e}$ in the presence of $\mathrm{Ca}(\mathrm{OCl})_{2}$ or $t-\mathrm{BuOCl}$ as the catalysts in $\mathrm{CH}_{3} \mathrm{CN}$ generating esters 179a-e proceeds through the Hock-like rearrangement mechanism (Table 12) [322].

The fragmentation of hydroperoxy acetals $\mathbf{1 7 8}$ to esters $\mathbf{1 7 9}$ involves the formation and heterolytic fragmentation of intermediate secondary chloroperoxides $\mathbf{1 8 0}$. The possible mechanism of the process is presented in Scheme 54.

The acid-catalyzed rearrangement of phenylcyclopentyl hydroperoxide 181, involving the Hock reaction, is accompanied by the formation of a series of products: 1-phenylcyclopentene

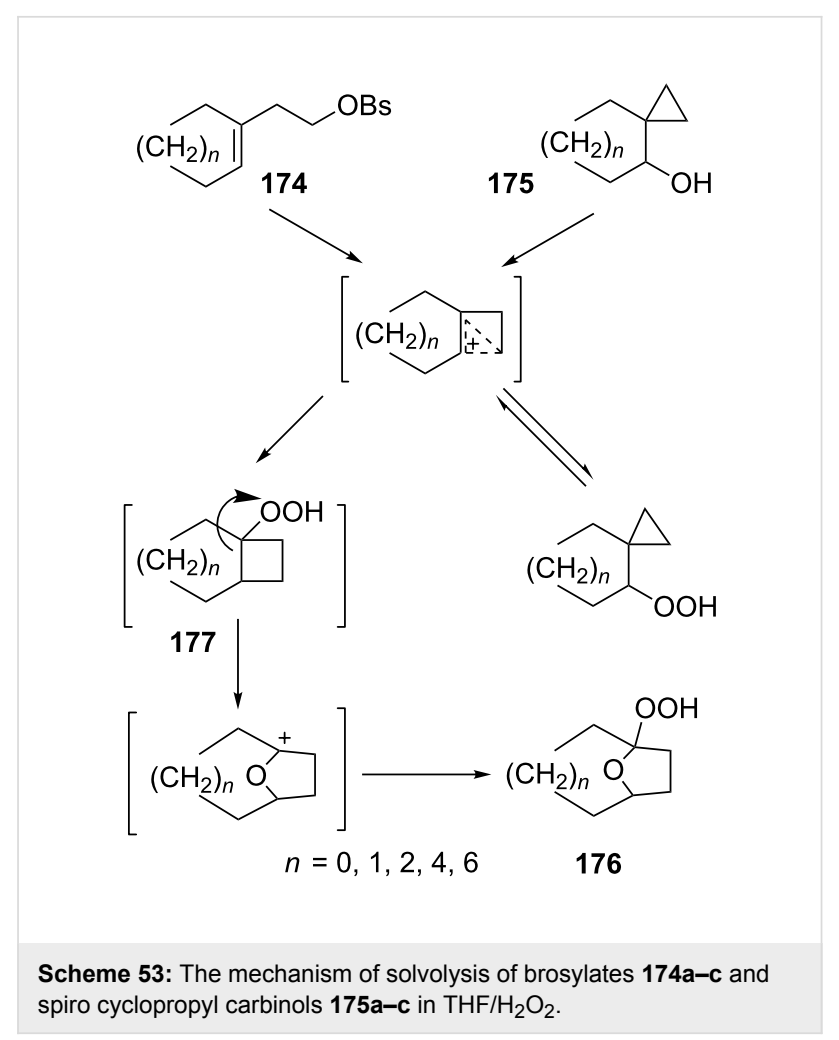

(182), phenol (170), cyclopentanone (183), and 5-acetoxyvalerophenone (184) (Scheme 55) [323].

An attempt was made [324] to synthesize hydroperoxides through the peroxidation of tertiary alcohols in the presence of a catalytic amount of acid. The treatment of $\mathbf{1 8 5}$ with $\mathrm{H}_{2} \mathrm{O}_{2}$ in the presence of a catalytic amount of $\mathrm{H}_{2} \mathrm{SO}_{4}$ for 72 hours did not lead to the formation of products via the Hock rearrangement of hydroperoxides, bicyclic hydroperoxides and $o$-hydroxyphenyl alkyl ketones. Instead, cyclic 2-methylchroman-2-yl hydroper-

Table 11: Solvolysis of brosylates $174 a-c$ and spiro cyclopropyl carbinols $175 a-c$ in the $\mathrm{THF} / \mathrm{H}_{2} \mathrm{O}_{2}$ system.

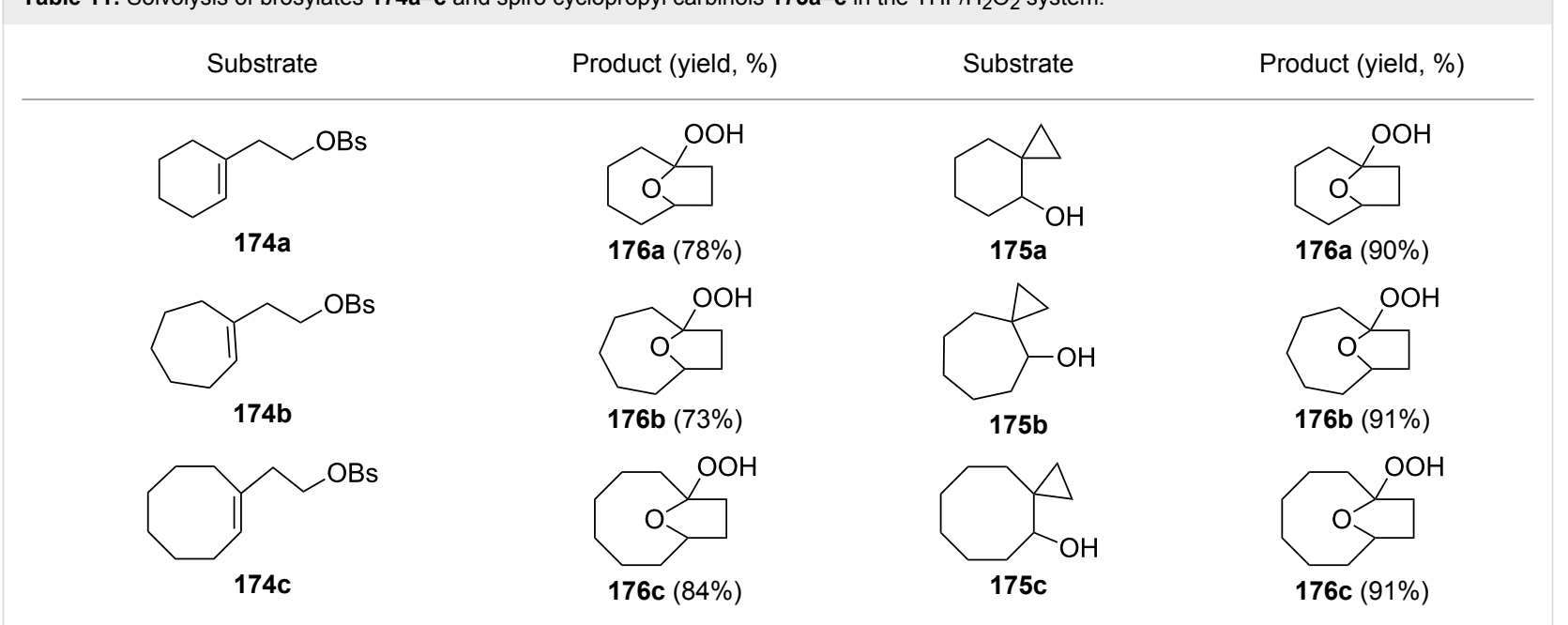


Table 12: Fragmentation of hydroperoxy acetals $178 \mathrm{a}-\mathbf{e}$ catalyzed by $\mathrm{Ca}(\mathrm{OCl})_{2}$ or $t-\mathrm{BuOCl}$.

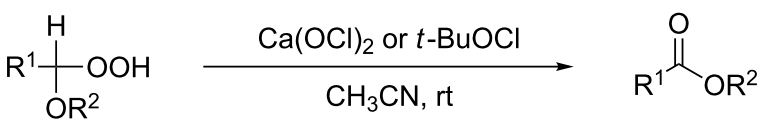

178a: $R^{1}=$ octyl, $R^{2}=M e ;$

$179 a-e$

b: $R^{1}=$ octyl, $R^{2}=E t ;$

c: $\mathrm{R}^{1}=$ octyl, $\mathrm{R}^{2}=\left(\mathrm{CH}_{2}\right)_{2} \mathrm{OH}$;

d: $\mathrm{R}^{1}=\mathrm{AcO}\left(\mathrm{CH}_{2}\right)_{8}, \mathrm{R}^{2}=\mathrm{Me}$;

e: $\mathrm{R}^{1}=$ octyl, $\mathrm{R}^{2}=\left(\mathrm{CH}_{2}\right)_{2} \mathrm{Cl}$

\begin{tabular}{cccccccc}
\hline Substrate & Product & $\mathrm{Ca}(\mathrm{OCl})_{2}$ (equiv) & Time $(\mathrm{min})$ & Yield, $\%$ & $t$-BuOCl (equiv) & Time (min) & Yield, \% \\
\hline $\mathbf{1 7 8 a}$ & $\mathbf{1 7 9 a}$ & 1.3 & 10 & 75 & 0.25 & 15 & 78 \\
$\mathbf{1 7 8 b}$ & $\mathbf{1 7 9 b}$ & 1.3 & 10 & 86 & 1.2 & 10 & 85 \\
$\mathbf{1 7 8} \mathbf{1 7 9}$ & $\mathbf{1 7 9}$ & 1.3 & 10 & 83 & 1.2 & 10 & 84 \\
$\mathbf{1 7 8 d}$ & $\mathbf{1 7 9 d}$ & 1.3 & 10 & 85 & 0.25 & 15 & 85 \\
$\mathbf{1 7 8} \mathbf{1 7 9}$ & $\mathbf{1 7 9}$ & 1.3 & 10 & 82 & 1.2 & 10 & 84
\end{tabular}

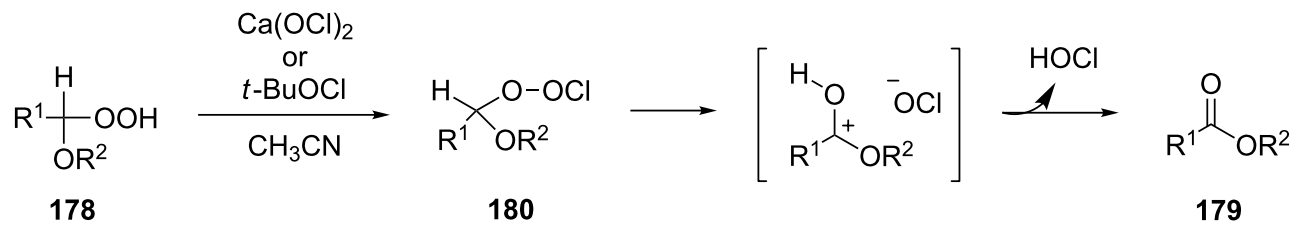

Scheme 54: The fragmentation mechanism of hydroperoxy acetals 178 to esters 179.

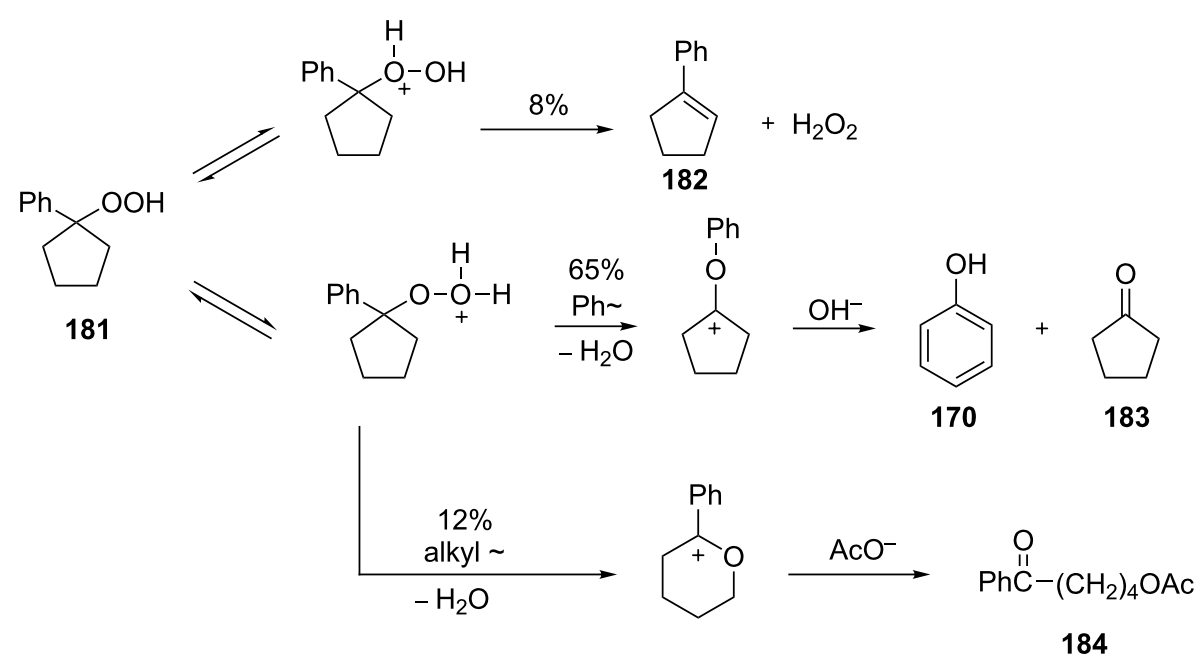

Scheme 55: The acid-catalyzed rearrangement of phenylcyclopentyl hydroperoxide 181.

oxide 188, geminal bishydroperoxides 190, and condensation products of peroxides such as $\mathbf{1 9 1}$ were isolated (Scheme 56).

The reaction mechanism presumably involves the following steps: the replacement of the hydroxy group by hydrogen peroxide to form tertiary hydroperoxides $\mathbf{1 8 6}$, the acid-catalyzed rearrangement of compounds 186 into cyclic phenoxycarbenium ions 187, and the addition of the second hydrogen peroxide molecule to $\mathbf{1 8 7}$ resulting in the formation of cyclic phenoxy hydroperoxide $\mathbf{1 8 8}$. The latter was isolated as the 
<smiles></smiles>

185<smiles>[R]C1(O)CNc2ccccc2O1</smiles><smiles>C[PH3+]</smiles><smiles>C=CC</smiles><smiles>[R]C1(OO)CCc2ccccc21</smiles>

186

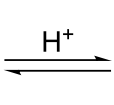<smiles>[R]C1(O[Na])CCCc2ccccc21</smiles>

187<smiles>[R]C1CCCCC1COCCO</smiles><smiles>[R]C1CCCCC1COCCO</smiles><smiles>[R]C1CCCCC1COCCO</smiles><smiles>[R]C(O)CCCc1ccccc1O</smiles>

189<smiles>[R]C(O)(O)C(=O)Nc1ccccc1O</smiles><smiles>[R]C1(O)CC=[V]c2ccccc2O1</smiles>

188

$190 n=2,3$

Scheme 56: The peroxidation of tertiary alcohols in the presence of a catalytic amount of acid.

major product in the case of the six-membered ring $(n=1)$. In the case of the seven-membered ring $(n=2)$, geminal dihydroperoxide 190 and bridged bis(hydroxy)dialkyl peroxide 191 were obtained instead of $\mathbf{1 8 8}$. In case of the eight-membered ring $(n=3)$ an exclusive transformation into geminal dihydroperoxide 190 was observed (Table 13).

The formation of geminal dihydroperoxides 195 was also observed in the acid-catalyzed reaction of bicyclic secondary alcohols 192 with hydrogen peroxide. This reaction starts with the formation of bicyclic hydroperoxides 193 followed by the acidcatalyzed rearrangement with intermediate formation of peroxy hemiacetal 194. The latter is finally transformed into primary geminal bishydroperoxides 195 (Scheme 57) [325].

The photooxidation of 5,6-disubstituted 3,4-dihydro- $2 \mathrm{H}$-pyrans 196 generates the stable hydroperoxide 197 as the major product, which rearranges into dioxetane 198 at $28{ }^{\circ} \mathrm{C}$ in $\mathrm{CCl}_{4}$ within $13 \mathrm{~h}$. Compounds 198 can be further transformed into keto esters 199 by treatment for $24 \mathrm{~h}$ with triphenylphosphine in $\mathrm{CCl}_{4}$ or concentrated $\mathrm{HCl}$ in $\mathrm{CCl}_{4}$. When compound 197 is heated at $70{ }^{\circ} \mathrm{C}$ its rearrangement into 199 occurs very rapidly and dioxetane $\mathbf{1 9 8}$ was not detected (Scheme 58) [326,327].

Table 13: Yields of products 188, 190, and 191.

Entry

$\mathrm{R}$

$n$

185

$\left(185: \mathrm{H}_{2} \mathrm{O}_{2}\right)$

Yield, \%

188

190

191

$1 \quad$ Me $\quad 1 \quad$ a $\quad$ (1:10)

$2 \mathrm{Me}$

b

$(1: 10)$

a (65)

b 
<smiles>[X]c1ccccc1C(O)O</smiles>

192<smiles>[X]c1ccccc1C(C)OCOCC</smiles>

193<smiles>[X]c1ccccc1O[C+]Cc1ccccc1</smiles><smiles>[3H][14OH]</smiles>

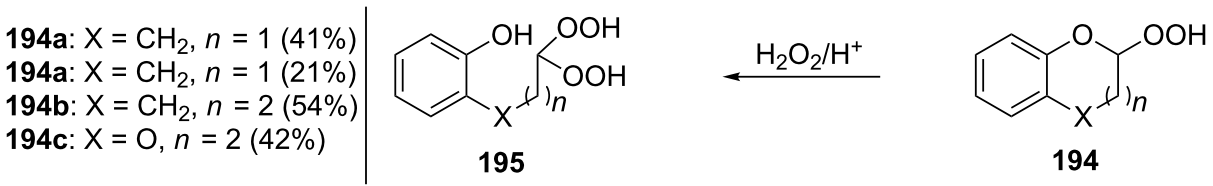

Scheme 57: The acid-catalyzed reaction of bicyclic secondary alcohols 192 with hydrogen peroxide.<smiles>[R]C1=C(C)OCCC1</smiles>

196a: $\mathrm{R}=\mathrm{CO}_{2} \mathrm{Et}$

196b: $\mathrm{R}=\mathrm{COCH}_{3}$

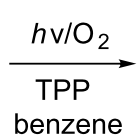

benzene<smiles>[R]C1(O)CCCOC1=C</smiles>

197

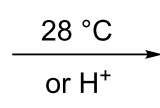<smiles>[R]C12CCCOC1(C)OO2</smiles>

198

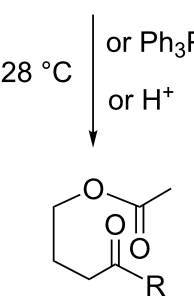

199

Scheme 58: The photooxidation of 5,6-disubstituted 3,4-dihydro-2H-pyrans 196.

The oxidation of tertiary alcohols $200 \mathbf{a}-\mathbf{g}, \mathbf{2 0 3 a}, \mathbf{b}$, and 206, involving the rearrangement of hydroperoxides $201 \mathbf{a}-\mathbf{g}, 204 \mathbf{a}, \mathbf{b}$, and 207, occurs in good yields in the presence of such systems as $\mathrm{NaBO}_{3} \cdot 4 \mathrm{H}_{2} \mathrm{O} / \mathrm{BF}_{3} \cdot \mathrm{Et}_{2} \mathrm{O}$ [328], $\mathrm{H}_{2} \mathrm{O}_{2} / \mathrm{BF}_{3} \cdot \mathrm{Et}_{2} \mathrm{O}$, and $\mathrm{H}_{2} \mathrm{O}_{2} / p$ $\mathrm{TsOH}$ [329] (Scheme 59). The Hock rearrangement can be used to prepare alcohols 202a-g, 205, and 208 containing electrondonating substituents.

The intramolecular capture of the cationic intermediate derived from the Hock rearrangement of peroxyketone 209 provides a direct and efficient one-step synthesis of 2,3-disubstituted furans 210 (Scheme 60) [330].

The benzannulation of indoles 211 can be performed with $\gamma$-carbonyl tert-butyl peroxides $\mathbf{2 1 2}$ catalyzed by trifluoromethanesulfonic acid to give carbazoles 213. The key step of this approach is based on the acid-catalyzed rearrangement of tertbutyl peroxides (Scheme 61) [331].

The direct dehydrogenative construction of $\mathrm{C}-\mathrm{N}$ bonds between unprotected phenols 215 and a series of $10 H$-phenox- azines and $10 \mathrm{H}$-phenothiazines $\mathbf{2 1 4}$ with formation of $\mathbf{2 1 6}$ was carried out using a Hock-like activation with $\mathrm{O}_{2}$ followed by amine oxidation (Scheme 62) [332].

The Hock rearrangement plays an important role not only in fine organic synthesis but also in biological processes. Scheme 63 shows the proposed mechanism for the biosynthetic conversion of $\mathbf{2 1 7}$ to $\mathbf{2 1 8}$, which is an important component of the structural skeleton of the antitumor-antibiotic CC-1065 [333].

The synthetic model of the in vivo oxidation of cholesterol (219) by singlet oxygen produces cholesterol-5 $\alpha-\mathrm{OOH} \mathbf{2 2 0}$, which is subjected to a Hock reaction to form the aldolization product 221 and keto aldehyde (atheronal A, 222) (Scheme 64) [67].

Keto aldehyde (atheronal A, 222) exhibits proatherogenic activity and plays a causal role in the development of cardiovascular diseases [66]. The proposed mechanism of the rearrangement of cholesterol- $5 \alpha-\mathrm{OOH} \mathbf{2 2 0}$ is presented in Scheme 65. 


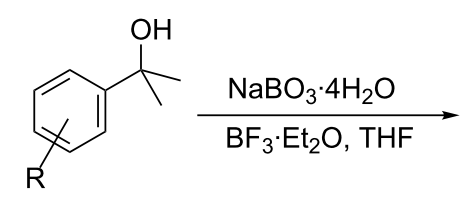

200a: $R=4-O M e$

b: $\mathrm{R}=3,4-(\mathrm{OMe})_{2}$

c: $\mathrm{R}=2,4-(\mathrm{OMe})_{2}$

d: $\mathrm{R}=2,6-(\mathrm{OMe})_{2}$

e: $\mathrm{R}=4-\mathrm{Me}$

$R=2,4-(M e)_{2}$

g: $R=B r$<smiles>[R]C(C)(O)c1cccc2c1NCC2</smiles>

203a: $\mathrm{R}=\mathrm{H}$

b: $\mathrm{R}=\mathrm{CH}_{3}$<smiles>COc1cc2c(cc1C(C)(C)O)CCCC2</smiles>

206<smiles>[R]c1ccc(C(C)(C)OO)cc1</smiles>

201a-g<smiles>[R]C1CCC2(O)CCC(C1)C2</smiles>

202a: $93 \%$

b: $87 \%$

c: $90 \%$

d: $93 \%$

e: $73 \%$

g: $23 \%$

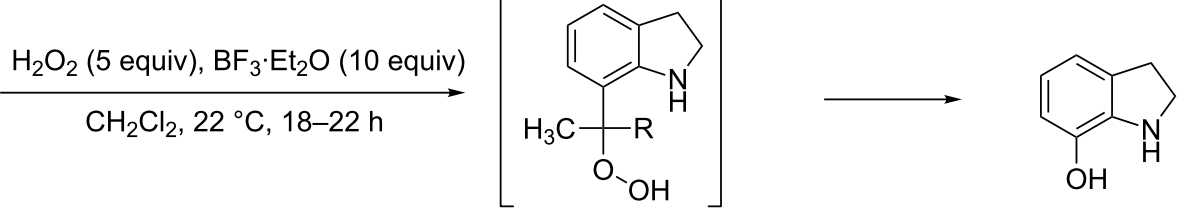

204a,b<smiles>COc1cc2c(cc1O)CCC(CC(C)(C)OO)CC2</smiles>

208

Scheme 59: The oxidation of tertiary alcohols $200 a-g, 203 a, b$, and 206

$$
\begin{aligned}
& \text { 209 }
\end{aligned}
$$

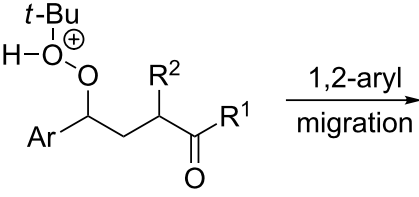

$$
\begin{aligned}
& \mathrm{R}^{1}=\text { alkyl, aryl } \\
& \mathrm{R}^{2}=\mathrm{C}(\mathrm{O}) \mathrm{R}, \mathrm{CN}
\end{aligned}
$$

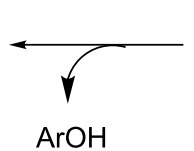

Scheme 60: Transformation of functional peroxide 209 leading to 2,3-disubstitued furans 210 in one step.<smiles>c1ccc2[nH]ccc2c1</smiles>

211<smiles>[R]C(=O)C([R])CC(OO[R19]([H])([H])[H])c1ccccc1</smiles>

212

$\mathrm{R}^{1}=$ alkyl, ary

$\mathrm{R}^{2}=\mathrm{C}(\mathrm{O}) \mathrm{OR}, \mathrm{C}(\mathrm{O}) \mathrm{Ph}$<smiles>[R]c1ccc2c([nH]c3c(C)cccc32)c1[R]</smiles>

$213,51-70 \%$ 

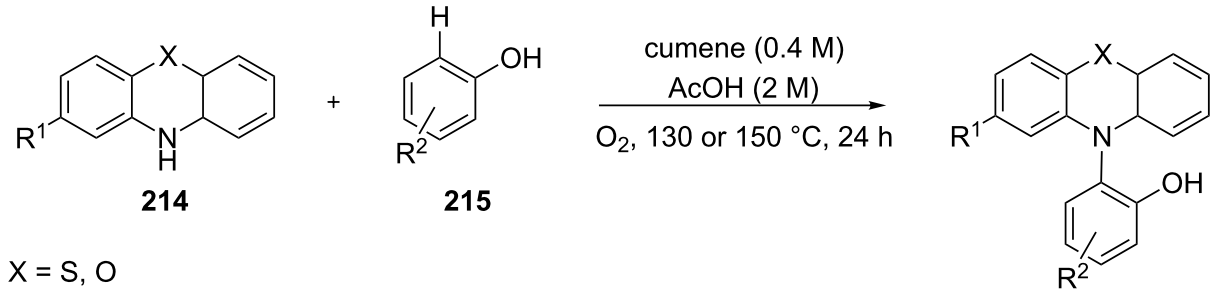

$\mathrm{X}=\mathrm{S}, \mathrm{O}$

$\mathrm{R}^{1}=\mathrm{Cl}, \mathrm{CF}_{3}, \mathrm{COCH}_{3}, \mathrm{CN}, \mathrm{H}$

$\mathrm{R}^{2}=\mathrm{H}$, alkyl

216, 33-99\%

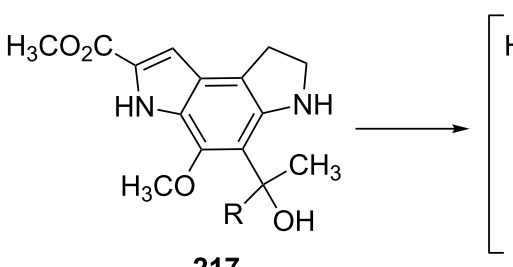

217<smiles>[R]C(C)(O)c1c2c(c3cc(C(=O)OC)[nH]c3c1OC)CCN2</smiles>

$\downarrow$

$\mathrm{H}_{3} \mathrm{CO}_{2} \mathrm{C}$<smiles>[R]N1CCc2c1c(O)c(OC)c1[nH]c(C)cc21</smiles>

218

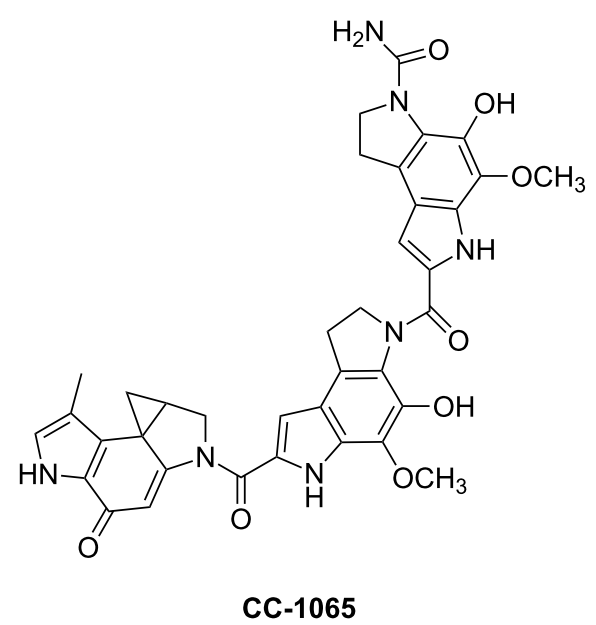

Scheme 63: The synthesis of moiety 218 from 217 which is a structural motif in the antitumor-antibiotic of CC-1065.<smiles>CC(C)CCC[C@H](C)[C@H]1CC[C@H]2[C@@H]3CC=C4C[C@@H](O)CC[C@]4(C)[C@H]3CC[C@]21C</smiles>

219

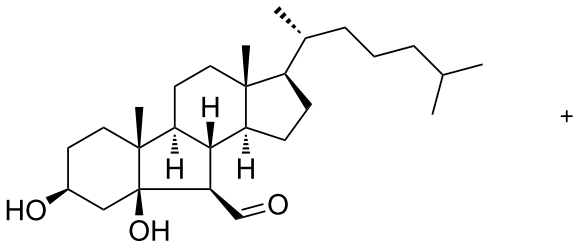

221<smiles>CC(C)CCC[C@H](C)[C@H]1CC[C@H]2C3C=C[C@]4(O)C[C@@H](O)CC[C@]4(C)[C@@H]3CC[C@]21C</smiles>

220

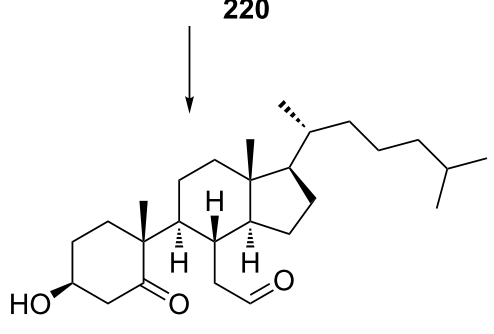

222 
<smiles>C#C[C@H]1C=C[C@@]2(OO)C[C@@H](O)CC[C@]2(C)[C@H]1C</smiles>

220

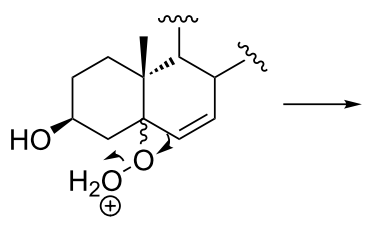

$\oplus$<smiles>C=CC1C=CO[C@]2(CO)C[C@H](O)CC[C@]2(C)[C@H]1C</smiles><smiles>CC1C=COC2(O)C[C@H](O)CC[C@]2(C)C1C</smiles><smiles>C=C</smiles><smiles>C#CCC(C)C(C)C(C)C1(CC)CC[C@@H](O)CC1=O</smiles>

222

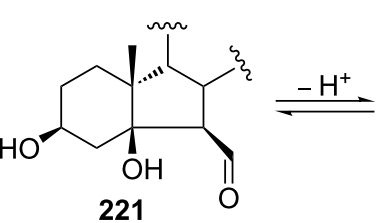<smiles>CC1C(C=O)C(C)C2(O)CC[C@@H](O)CC12C</smiles><smiles>C=CC=C</smiles>

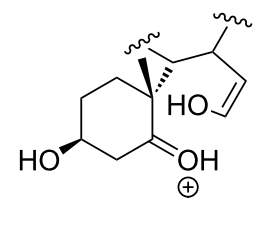

$\mathrm{ROH}$<smiles>[R]C1(O)C[C@@H](O)CC[C@]1(C)[C@H](C)[C@@H](C)CC=C</smiles>

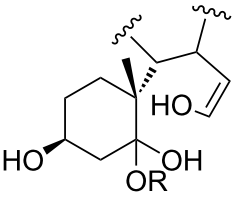<smiles>C#[P+]</smiles>

Scheme 65: The proposed mechanism of the rearrangement of cholesterol-5a-OOH 220.

Therefore, the acid-catalyzed Hock rearrangement of hydroperoxide 220 is a key step in the oxidation of cholesterol (219).

In a photochemical route developed for the synthesis of artemisinin the Hock rearrangement of hydroperoxide $\mathbf{2 2 3}$ selectively affords enol $\mathbf{2 2 4}$. This reactive intermediate $\mathbf{2 2 4}$ is then finally oxidized into artemisinin (Scheme 66) [334].

\subsection{Kornblum-DeLaMare rearrangement}

The Kornblum-DeLaMare rearrangement (KDLM) is a rearrangement of organic peroxides A containing a primary or secondary carbon atom into ketones $\mathbf{B}$ and alcohols $\mathbf{C}$ mainly under base-catalyzed reaction conditions (Scheme 67) [335].

In 1951, Kornblum and DeLaMare observed that the treatment of 1-phenylethyl tert-butyl peroxide (225) with $\mathrm{KOH}, \mathrm{NaOEt}$, or pyridine resulted in the decomposition of $\mathbf{2 2 5}$ to give aceto-

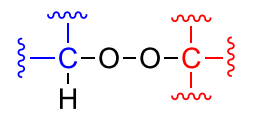

A

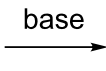

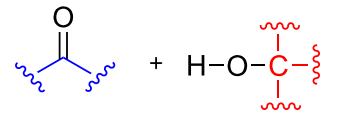

B
C
Scheme 67: The Kornblum-DeLaMare rearrangement.

phenone (227) and tert-butanol (228). A three-step mechanism for this reaction was proposed (Scheme 68) [336,337].

The reaction commences with a base-mediated $\alpha$-proton abstraction from $\mathbf{2 2 5}$ to form carbanion $\mathbf{2 2 6}$ and the latter decomposes to yield the tert-butoxide anion and acetophenone (227). These steps occur presumably in a concerted manner. Finally, the protonation of the tert-butoxide anion results in the formation of tert-butanol (228). As alternative bases $\mathrm{Et}_{3} \mathrm{~N}$<smiles>C[C@H](C(=O)O)[C@H]1CC[C@@H]2CCC(C)(OO)C=C2[C@H]1C</smiles>

223

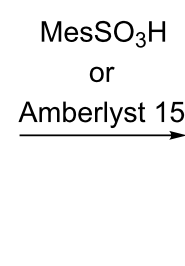

yst 15<smiles>CC(=O)CC[C@H]1C(=CO)C([C@@H](C)C(=O)O)CC[C@H]1C</smiles>

224

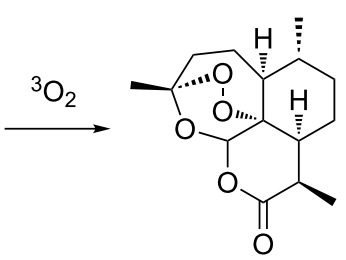

artemisinin

Scheme 66: Photochemical route to artemisinin via Hock rearrangement of 223. 


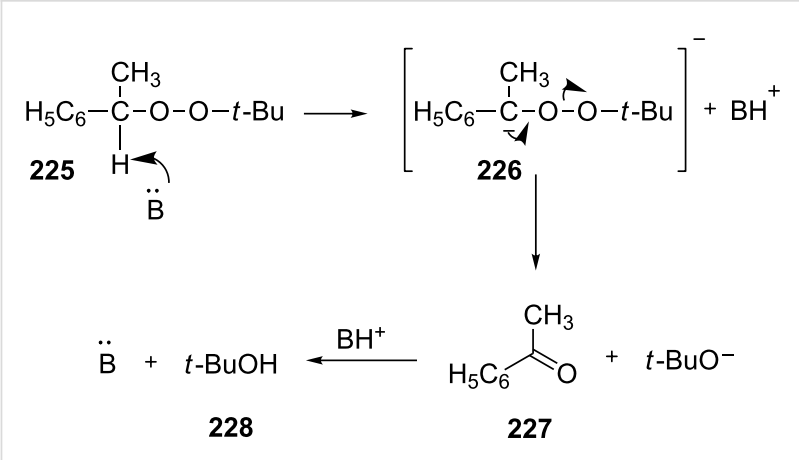

Scheme 68: Kornblum-DeLaMare transformation of 1-phenylethyl tertbutyl peroxide (225).

[338,339], phosphorus ylides [340] and LiOH [341,342] can be used and the Kornblum-DeLaMare rearrangement proceeds also on $\mathrm{SiO}_{2}$ [343].

The Kornblum-DeLaMare rearrangement is a convenient tool in organic chemistry for the conversion of monocyclic endoperoxides. These compounds are discussed in this review in the order of increasing ring size and the number of the starting substrates.

The treatment of unsubstituted bicyclic endoperoxides 229 by bases affords 4-hydroxyenones 230 [344] which are useful precursors in asymmetric organic syntheses. Alternative synthetic methods towards this class of compounds normally require a metal-catalyzed or biocatalyzed oxidation of diols 231 in an additional reaction step [345] (Scheme 69).

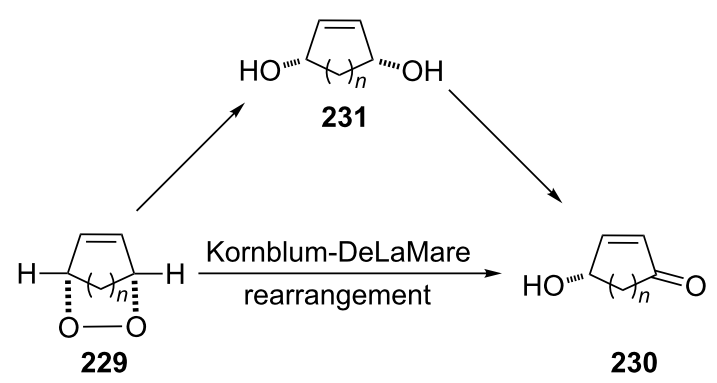

Scheme 69: The synthesis 4-hydroxyenones $\mathbf{2 3 0}$ from peroxide 229

The treatment of endoperoxide $\mathbf{2 3 2}$ with triethylamine in ethanol at room temperature results in the $\mathrm{O}-\mathrm{O}-$ bond cleavage to form 5-hydroxytropolone (233) (Scheme 70) [346].

It is interesting to note, that a reduction of the bicyclic endoperoxide 234 with thiourea in methanol at $10{ }^{\circ} \mathrm{C}$ produces similar to KDLM product tropolone $\mathbf{2 3 5}$ in $94 \%$ yield (Scheme 71 ) [347].

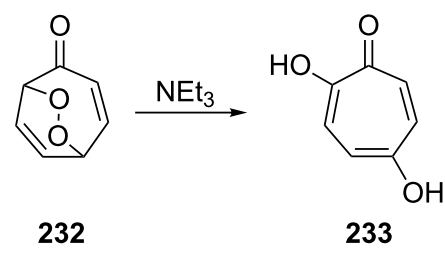

Scheme 70: The Kornblum-DeLaMare rearrangement of peroxide 232.

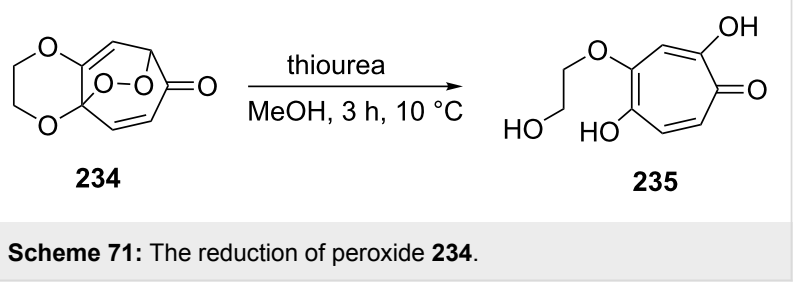

The Kornblum-DeLaMare reaction of the endoperoxide 236 with triethylamine in chloroform at $-30{ }^{\circ} \mathrm{C}$ affords tropolone 237 in $97 \%$ yield (Scheme 72) [347].

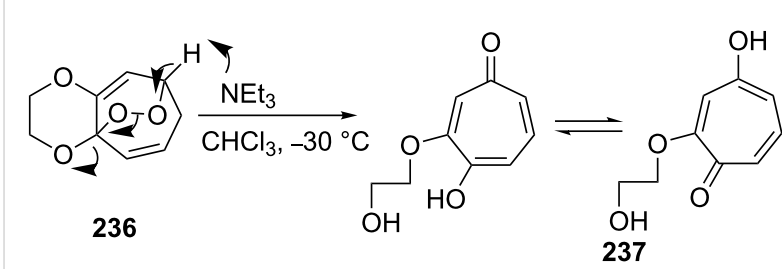

Scheme 72: The Kornblum-DeLaMare rearrangement of endoperoxide 236.

Tropolones exhibit a broad spectrum of biological activities, including antibacterial, antiviral, antifungal, anti-allergic, antioxidant, and anti-inflammatory [348,349].

The treatment of endoperoxide 238 with $\mathrm{Et}_{3} \mathrm{~N}$ gave 1,4-diketone $\mathbf{2 4 0}$ in quantitative yield instead of expected hydroxy ketone 239 (Scheme 73) [350-352].

The endoperoxide $\mathbf{2 3 8}$ is presumably converted into hemiketal 241, which is rearranged in several steps into diketone $\mathbf{2 4 0}$ (Scheme 74) [351].

The reaction of endoperoxide $\mathbf{2 4 2 a}$ containing an electron-donating substituent at the double bond with bases results in the rearrangement product diketone $\mathbf{2 4 3}$. Under the same conditions, the base-catalyzed rearrangement of endoperoxide $\mathbf{2 4 2 b}$ containing an electron-withdrawing substituent leads to a product mixture of hydroxy ketone 244, and diketones 245 and 246 (Scheme 75) [353]. 
<smiles>O=C1CCC(=O)c2ccccc2C1</smiles>

240

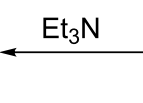<smiles>C1=CC2OOC1c1ccccc12</smiles>

238
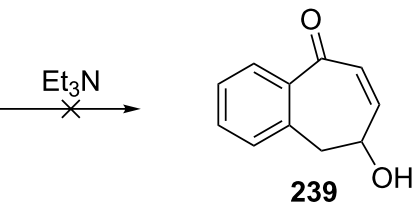

Scheme 73: The rearrangement of peroxide 238 under Kornblum-DeLaMare conditions.

$$
\stackrel{\mathrm{Et}_{3} \mathrm{NH}^{+}}{\stackrel{\mathrm{Et}_{3} \mathrm{~N}}{\longrightarrow}}
$$

238

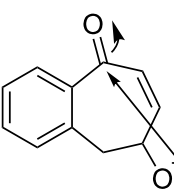

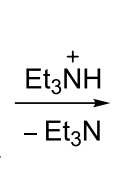<smiles>OC12C=CC(Cc3ccccc31)O2</smiles>
241 $\mathrm{Et}_{3} \mathrm{~N}$<smiles>O=C1CCC(=O)c2ccccc2C1</smiles><smiles>CCNCCNc1ccc2c(c1)C(O)=CC=C([O-])C2</smiles>
$\mathrm{HO}$
Scheme 74: The proposed mechanism of rearrangement of peroxide 238
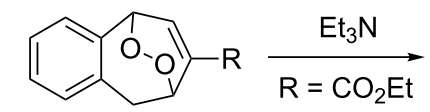

242a: $\mathrm{R}=\mathrm{CH}_{3}$

b: $\mathrm{R}=\mathrm{CO}_{2} \mathrm{Et}$ $\mathrm{R}=\mathrm{CH}_{3} \downarrow \mathrm{Et}_{3} \mathrm{~N}$

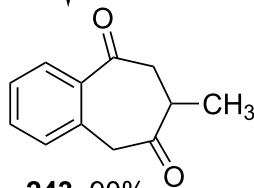

A further study [352] on the base-catalyzed rearrangements of substituted bicyclic endoperoxides showed that the pathway of the rearrangement is largely determined by the position of the substituent. The rearrangement of endoperoxides $247 \mathbf{a}, \mathbf{b}$ containing an electron-withdrawing substituent in the seven-membered ring occurs mainly via a retro-aldol cleavage giving rise to formyl benzoates 248a,b (Scheme 76).

On the other hand, endoperoxides 249a,b bearing electron-withdrawing groups (ester, acetyl) attached to the seven-membered ring are isomerized to diketones 250a,b (Scheme 77) [345].

The Kornblum-DeLaMare reaction of endoperoxide 251a containing an electron-withdrawing substituent at the bridge head<smiles></smiles><smiles>CCOC(=O)C1=C(O)Cc2ccccc2C(=O)C1</smiles>

Scheme 75: The Kornblum-DeLaMare rearrangement of peroxides 242a,b.

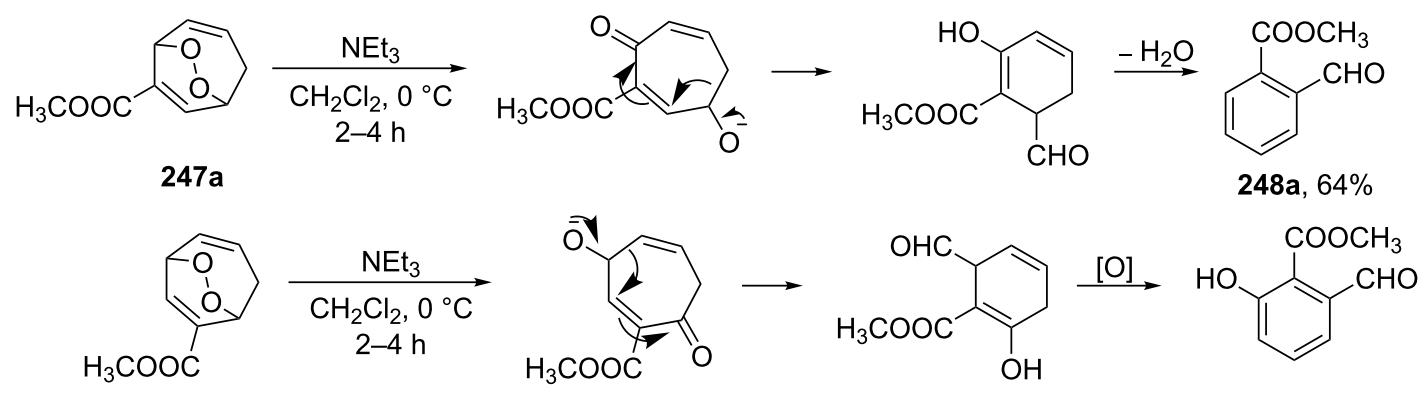


<smiles>[R]C1=CC2CCC(C1)OO2</smiles>

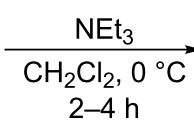

249a, $\mathrm{R}=\mathrm{COCH}_{3}$ 249b, R= $\mathrm{COOCH}_{3}$<smiles>[R]C1=CC(=O)CCC(=O)C1</smiles>

250a, $96 \%$

250b, $94 \%$

Scheme 77: The base-catalyzed rearrangements of bicyclic endoperoxides 249 a,b having electron-donating substituents.

atom lead to the 1,2-dicarbonyl compound 252a whereas the ester 251b polymerized upon treatment with triethylamine (Scheme 78).

The disproportionation of endoperoxide $\mathbf{2 5 3}$ promoted by triethylamine affords $\beta$ - and $\gamma$-hydroxy hydroperoxides 254 and 256. Under these conditions, the reaction afforded oxodiol 255 and diketone $\mathbf{2 5 7}$, which cyclized to hemiketal $\mathbf{2 5 8}$ as the products (Scheme 79) [354].

As the above reaction did not allow the isolation of hydroperoxide 254, an alternative strategy towards this compound was developed. The introduction of a protecting group into endoper-<smiles>CC(=O)C12CCC(CC1)OOC2</smiles>

251a

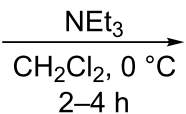
2-4 h<smiles>CC(=O)c1ccc(O)cc1</smiles>

252a, 35\%<smiles>COC(=O)C12CCC(CC1)OO2</smiles>

251b

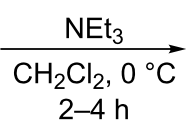

polymer
Scheme 78: The base-catalyzed rearrangements of bridge-head substituted bicyclic endoperoxides 251a,b.

oxide 253 using 2-methoxypropene gave protected peroxide 259. The subsequent triethylamine-catalyzed rearrangement of $\mathbf{2 5 9}$ leads to protected intermediate $\mathbf{2 6 0}$ the treatment of which under acidic conditions afforded hydroperoxide $\mathbf{2 5 4}$ in $70 \%$ yield (Scheme 80).

One approach to the enantioselective synthesis of 4-hydroxyenones $\mathbf{2 6 2}$ is based on the Kornblum-DeLaMare rearrange-

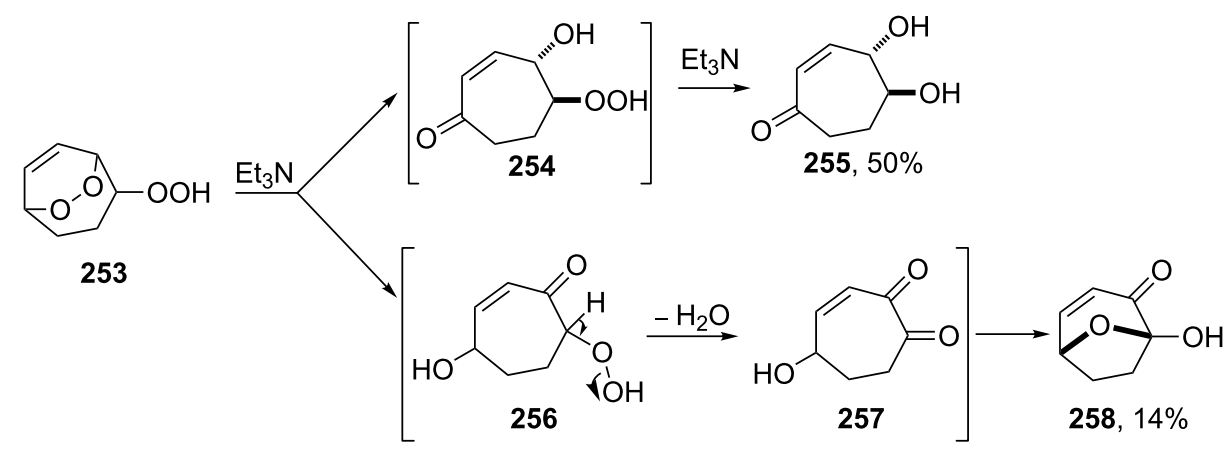

Scheme 79: The Kornblum-DeLaMare rearrangement of hydroperoxide 253.

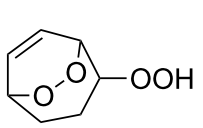

253

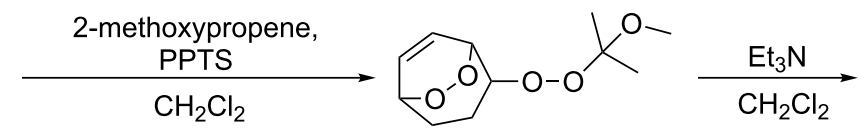

$259,84 \%$<smiles>CCOC(OCC(C)(C)OC1CCC(=O)C=CC1O)C(C)(C)O</smiles>

$260,58 \%$<smiles>O=C1C=CC(O)C(OO)CC1</smiles>

254, $70 \%$ 
ment of meso-endoperoxides $\mathbf{2 6 1}$ catalyzed by a chiral base [345] (Table 14).

The amine-catalyzed rearrangement of bicyclic endoperoxide 263 produced $(S)-(+)-4$-hydroxycyclohept-2-en-1-one (264), which was oxidized to bicyclic ketone $\mathbf{2 6 5}$. The synthetic value of chiral bicyclic ketone $\mathbf{2 6 5}$ was demonstrated by the transformation of this compound into $(+)$-sundiversifolide (266) (Scheme 81) [355].
The photooxidation of diene $\mathbf{2 6 7}$ followed by the base-catalyzed rearrangement of meso-endoperoxide 268 lead to $( \pm$ )trans, cis-4-hydroxy-5,6-di-O-isopropylidenecyclohex-2-en-1one (269). The protection of the hydroxy group in compound 269 provides an efficient route to functionalized 4-hydroxy-2cyclohexene-1-ones 270 (Scheme 82) [356].

The photooxidation of $\mathbf{2 7 1}$ in the presence of tetraphenylporphyrin produces endoperoxide $\mathbf{2 7 2}$, which undergoes a Korn-

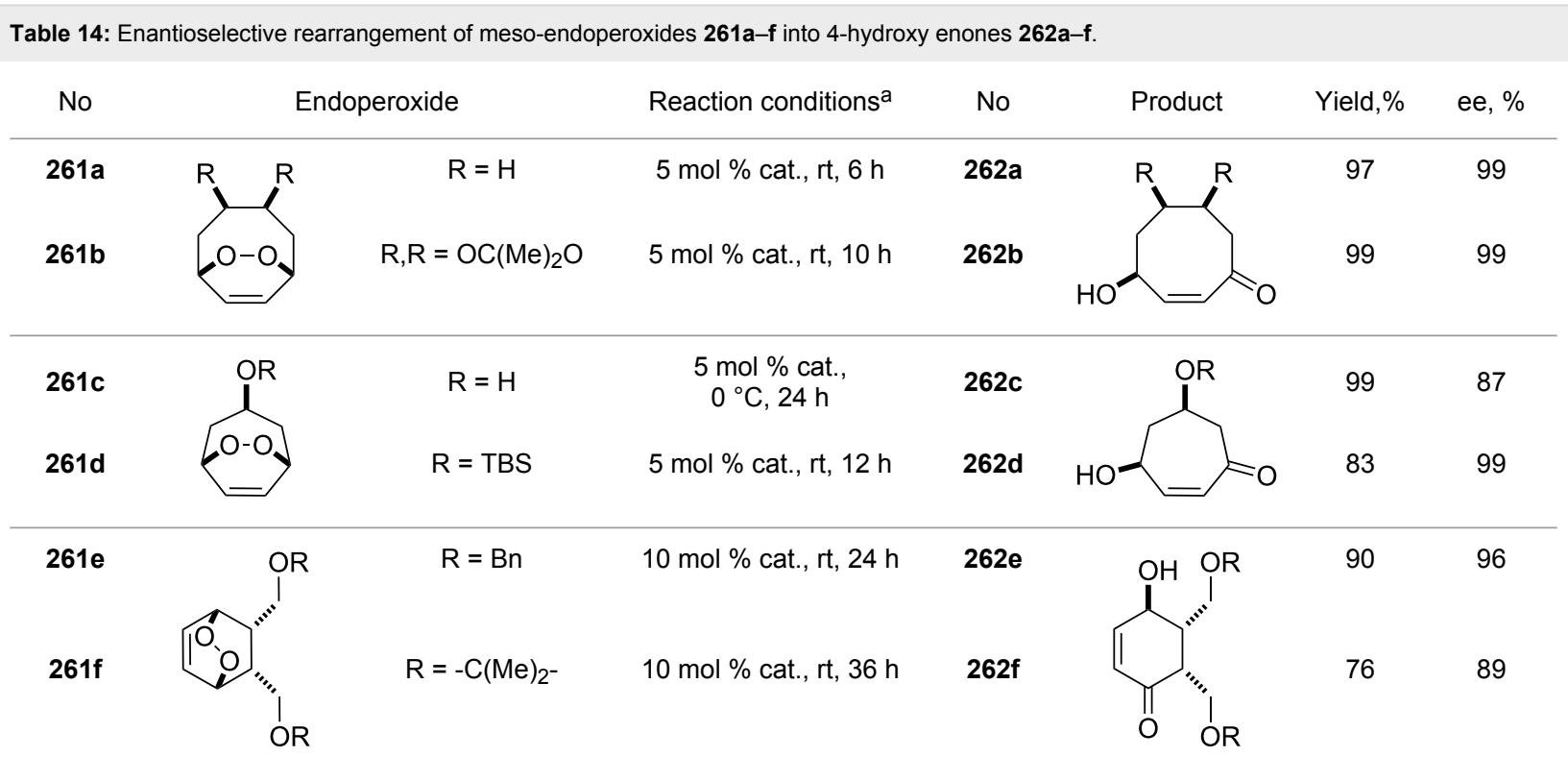<smiles>C=CC1CC2CCN1C2[C@H](OC(C)=O)c1ccnc2ccc(O)cc12</smiles>

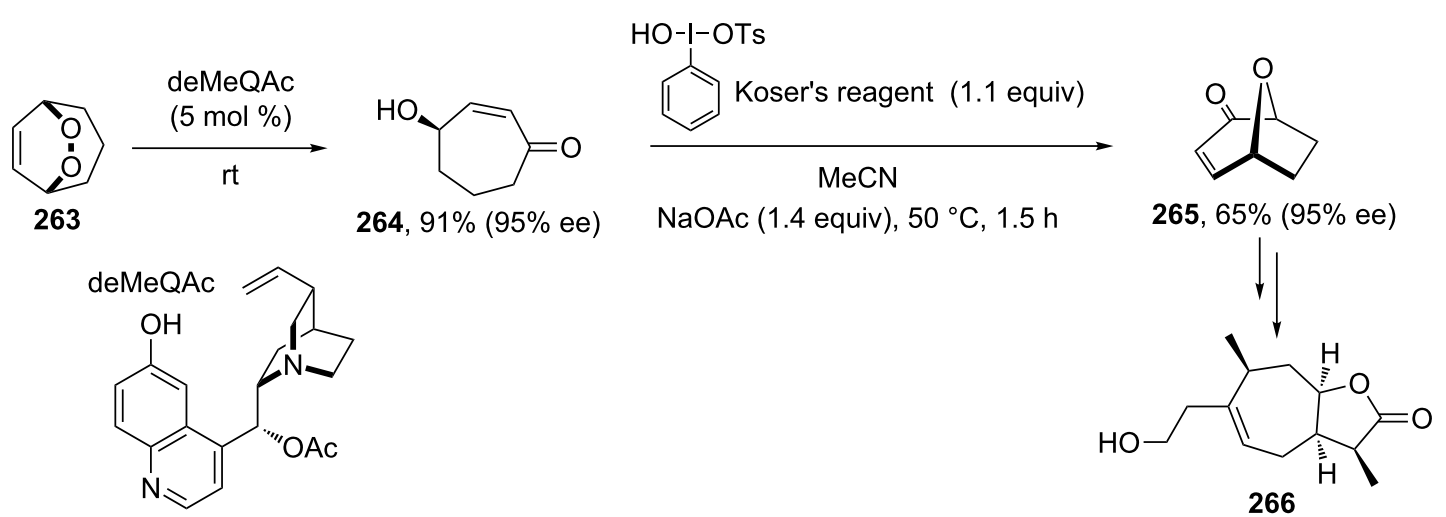

Scheme 81: The amine-catalyzed rearrangement of bicyclic endoperoxide 263. 


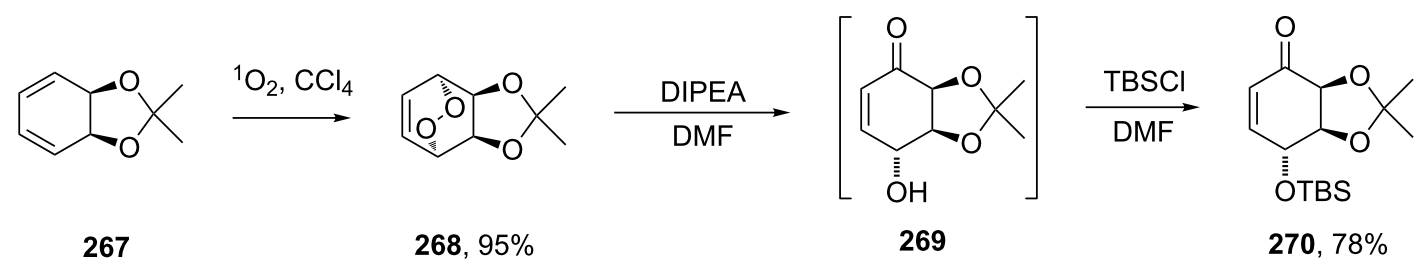

Scheme 82: The base-catalyzed rearrangement of meso-endoperoxide 268 into 269.

blum-DeLaMare transformation when treated with triethylamine. The obtained product 4-hydroxycyclohexen-2-one $\mathbf{2 7 3}$ releases benzoic acid through $\beta$-elimination under the basic conditions to give cyclohexadienone 274 (Scheme 83) [357].

The base-catalyzed isomerization of bicyclic saturated fulvene endoperoxides $\mathbf{2 7 5}$ is employed as one approach to the preparation of 2-alkenylcyclopentanones $\mathbf{2 7 6}$ and cyclopentenones $\mathbf{2 7 7}$ [358]. Thus, the treatment of a solution of endoperoxides $\mathbf{2 7 5}$ in $\mathrm{CH}_{2} \mathrm{Cl}_{2}$ with triethylamine while increasing the temperature from $0{ }^{\circ} \mathrm{C}$ to room temperature affords hydroxyketone 276. The use of the stronger base DBU results in the formation of 2-vinyl-2-cyclopentenones 277 in high yield (Table 15).

In the case of acyclic enamine $\mathbf{2 7 8}$, the initial dioxetane product from the photochemical oxidation of 279 rearranged to amide $\mathbf{2 8 0}$. The reactions using cyclic enamines $\mathbf{2 8 1}$ involve the Kornblum-DeLaMare rearrangement of dioxetanes $\mathbf{2 8 2}$ into 1,2-diketones 283 (Scheme 84) [359,360].

The Kornblum-DeLaMare rearrangement of 1,2-dioxenes $\mathbf{2 8 4}$ [361], 1,2-dioxanes 286 [362], and tert-butyl peroxides $\mathbf{2 8 8}$ [330,363] produces 1,4-dicarbonyl compounds $\mathbf{2 8 5}, \mathbf{2 8 7}$, and $\mathbf{2 8 9}$, respectively (Scheme 85 ). These compounds are versatile starting substrates for the synthesis of various heterocyclic systems, such as furan, thiophene, and pyrrole derivatives.

The reaction of unsymmetrical epoxy dioxanes 290a-d with triethylamine is accompanied by the 1,2-dioxane-ring opening to form 4-hydroxy-2,3-epoxy ketones 291a-d in high yields. The

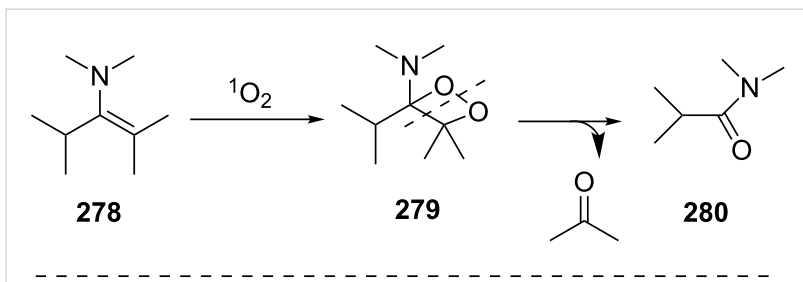<smiles>[R]C1CCCCC1</smiles>

281<smiles>CC1OOC1(C)N</smiles>

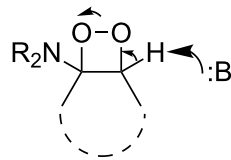

282
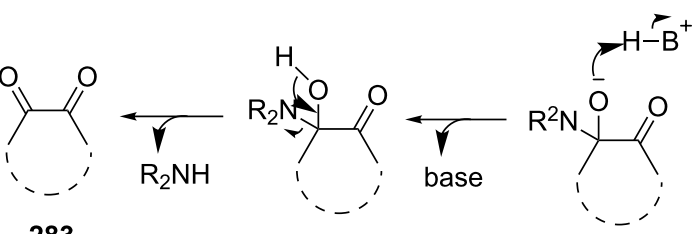

283

Scheme 84: The Kornblum-DeLaMare rearrangement as one step in the oxidation reaction of enamines.

base catalysis involves the abstraction of the most acidic $\alpha$-proton in the vicinity of the $\mathrm{O}-\mathrm{O}$ bond followed by the rearrangement accompanied by the $\mathrm{O}-\mathrm{O}-$ bond cleavage to form 4-hydroxy-2,3-epoxy ketones (Scheme 86) [364].

The Kornblum-DeLaMare rearrangement is of special synthetic value in view of the synthesis of biologically active com-

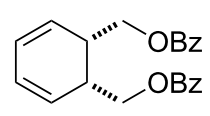

271

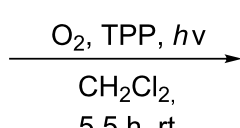

$5.5 \mathrm{~h}, \mathrm{rt}$<smiles>CC(C)(C)OC[C@H]1C2C=CC(O2)[C@H]1COC(C)(C)C</smiles>

$272,45 \%$

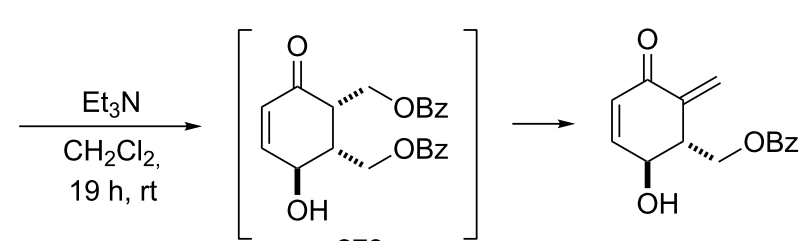

273

274, $98 \%$ 
Table 15: DBU-catalyzed isomerization-dehydration of saturated fulvene endoperoxides 275 to form 2-vinyl-2-cyclopentenones 277.

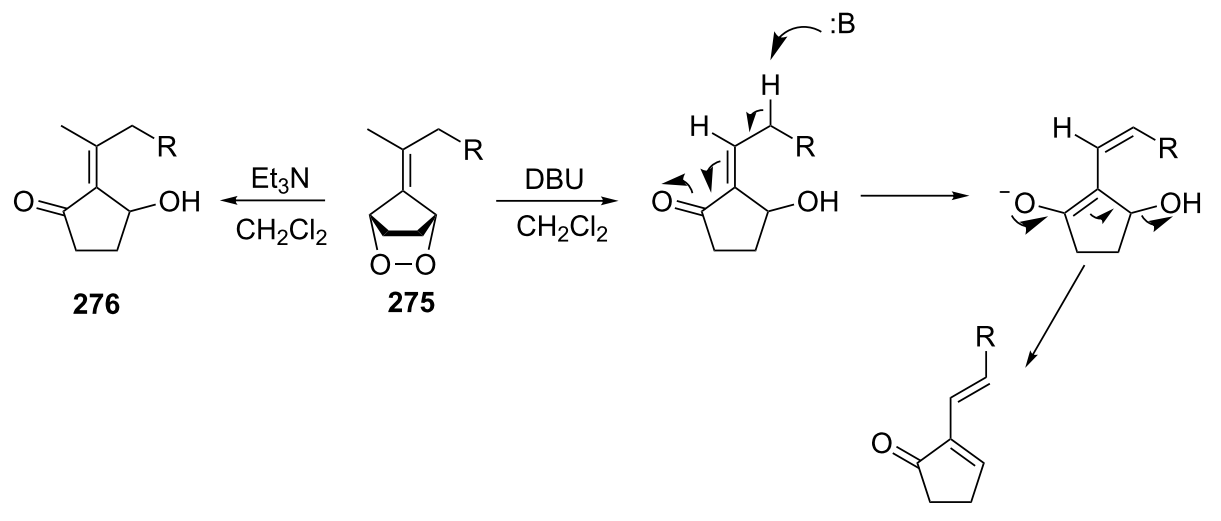

277

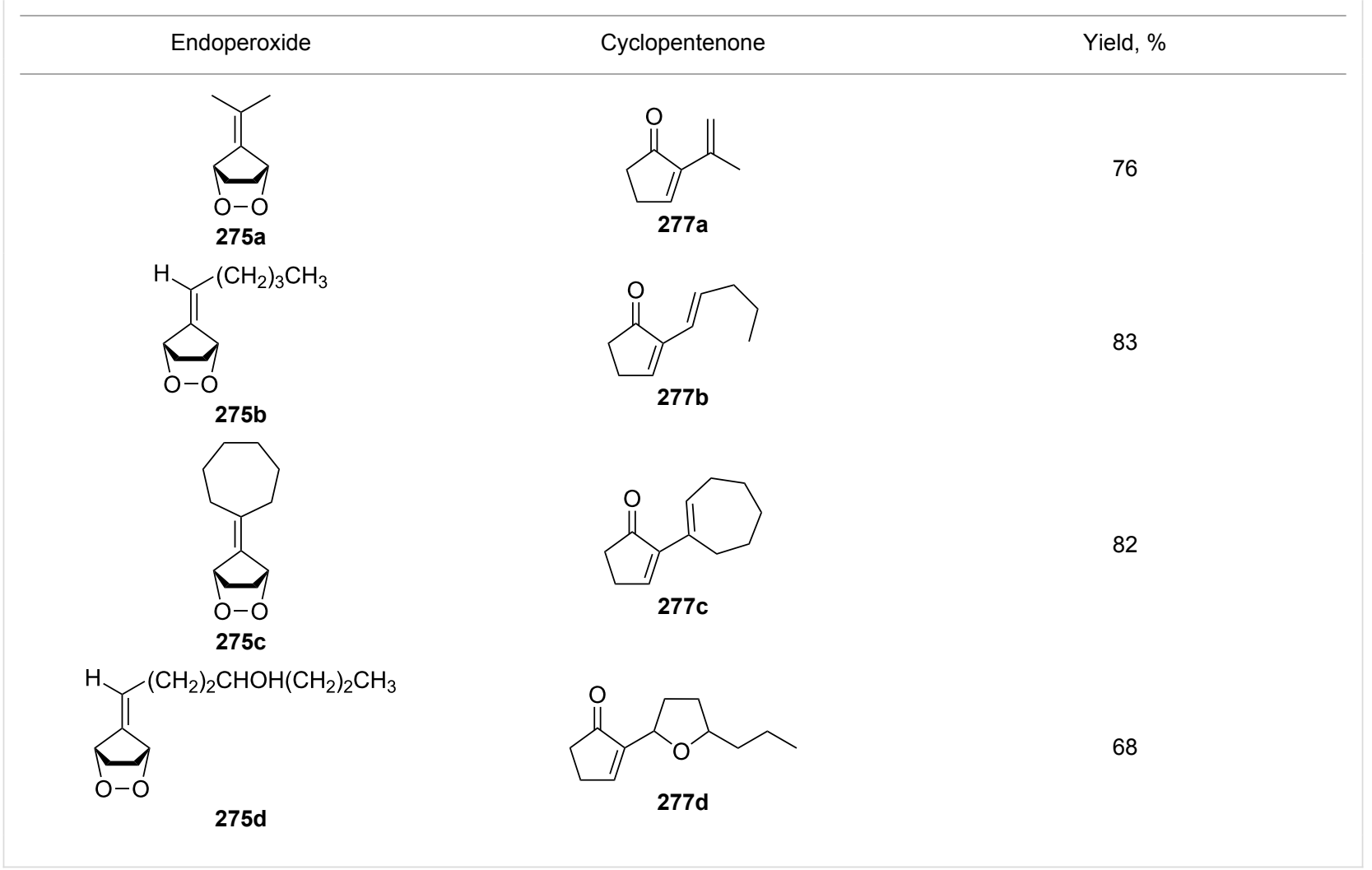

pounds. For instance, prostaglandin $\mathrm{H}_{2}$ (292) containing the bicyclic [2.2.1]endoperoxide moiety is rearranged in situ into prostaglandin $\mathrm{E}_{2}$ (293) (Scheme 87) $[365,366]$.

Nicolaou et al. [367] described the synthesis of epicoccin G (297) and related diketopiperazines 296 through the photooxidation of $\mathbf{2 9 4}$ and the Kornblum-DeLaMare rearrangement of peroxide 295 (Scheme 88).

The base-catalyzed transformation of organic peroxide 298 was used to synthesize compound 299, a precursor for the synthesis of the natural compound phomactin A (300). Phomactin A is a representative of a new class of platelet-activating factor (PAF) antagonists (Scheme 89) [368].

In another study [369], the transformation of peroxide 302, produced from 301, was applied to prepare compounds such as $3 \mathrm{H}$-quinazolin-4-one $\mathbf{3 0 3}$, which is a core subunit of some important quinazolinone-based drugs (Scheme 90).

The Kornblum-DeLaMare rearrangement is one of the steps in the synthesis of the natural compound angelone from Nauclea, a plant species widely acclaimed for its anti-inflammatory and antibacterial utilities in traditional Chinese herbal medical 
<smiles>[R]C(=O)CCC(N)=O</smiles>

284

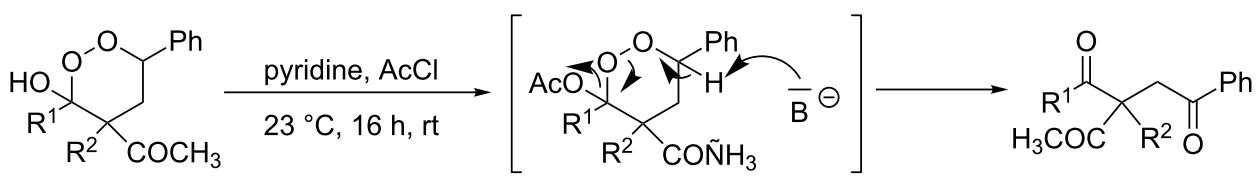

286

287

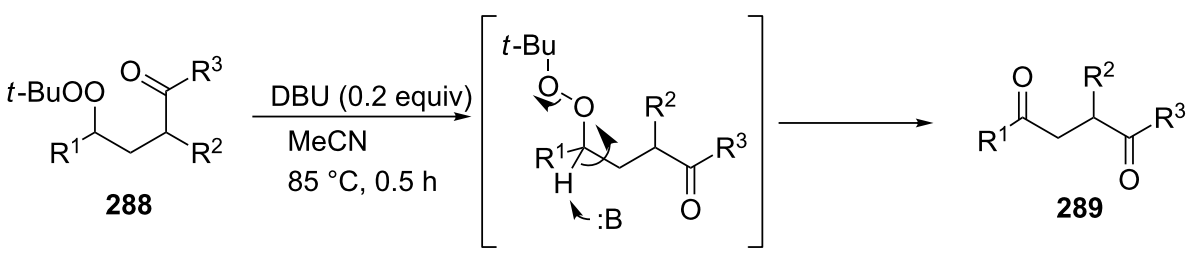

Scheme 85: The Kornblum-DeLaMare rearrangement of 3,5-dihydro-1,2-dioxenes 284, 1,2-dioxanes 286, and tert-butyl peroxides 288.<smiles>[R][R]1C2OOC([R])C1O2</smiles><smiles>[Mg][Mg]</smiles>

$$
\begin{aligned}
\text { 290a, } R & =P h, R^{1}=P h, R^{2}=H \\
\text { b, } R & =P h, R^{1}=M e, R^{2}=H \\
\text { c, } R & =P h, R^{1}=H, R^{2}=H \\
\text { d, } R & =P h, R^{1}=H, R^{2}=M e
\end{aligned}
$$

transformed into ketone $\mathbf{3 0 7}$ with good $92 \%$ yield by using $\mathrm{Et}_{3} \mathrm{~N}$ (Scheme 91) [371].

A sequence consisting of a template-mediated photooxygenation and an acid-catalyzed Kornblum-DeLaMare rearrangement of the intermediate endo-peroxides $\mathbf{3 1 0}$ was used in a onepot transformation of 3-substituted 2-pyridones 309 into the respective 3-hydroxypyridine-2,6-diones 311 with good enantioselectivity (69-86\% ee) (Scheme 92) [372].

Scheme 86: The Kornblum-DeLaMare rearrangement of epoxy dioxanes 290a-d.

formulations [370]. A Kornblum-DeLaMare enantiomeric resolution was also used to obtain both fragments of the polypropionate metabolite dolabriferol from a common precursor. The endoperoxide 304 was converted into ketone 305 with the help of the pseudo-enantiomeric quinine-derived catalyst (deMeQAc) in toluene with moderate $47 \%$ yield. The peroxide 306 was

The Kornblum-DeLaMare rearrangement of peroxide 312 into hydroxy enone $\mathbf{3 1 3}$ with high yields and regioselectivity has been reported in the total synthesis of $(+)$-zeylenol and its congeners (Scheme 93) [373].

The polyfunctionalized carbonyl compounds 317 were prepared via crossover oxidative coupling of ethers 316 with electron-deficient alkenes 315 and vinylarenes 314 in the presence

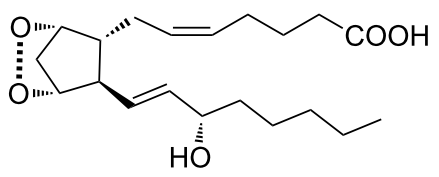

292

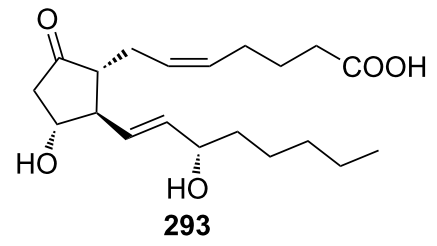




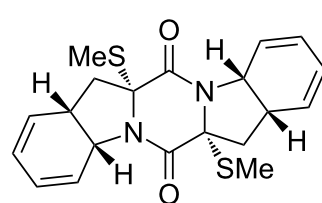

294

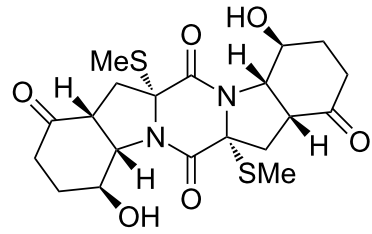

epicoccin G (297) a) $\mathrm{O}_{2}, h v$, TPP (0.02 equiv) $\mathrm{CH}_{2} \mathrm{Cl}_{2},-45^{\circ} \mathrm{C}, 40 \mathrm{~min}$

b) $\mathrm{DBU}$ (10.0 equiv), $\mathrm{CH}_{2} \mathrm{Cl}_{2},-45^{\circ} \mathrm{C}$ to $0{ }^{\circ} \mathrm{C}, 1 \mathrm{~h}$

$\mathrm{H}_{2}, \mathrm{Pd}(\mathrm{OH})_{2} / \mathrm{C}$

$\mathrm{MeOH}, 25^{\circ} \mathrm{C}, 1 \mathrm{~h}, 86 \%$

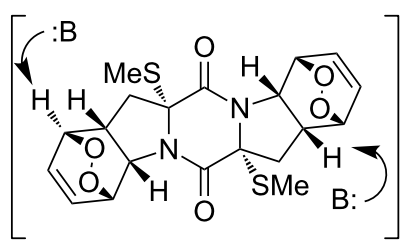

295

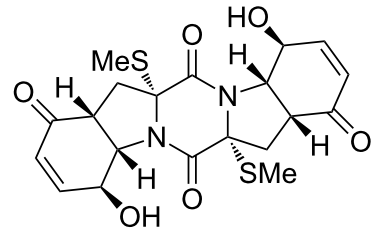

296, $52 \%$

Scheme 88: The synthesis of epicoccin G (297).

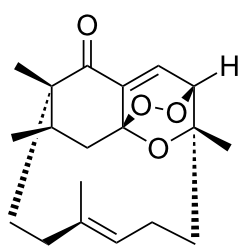

298
KOAc, 18-crown-6 THF, rt

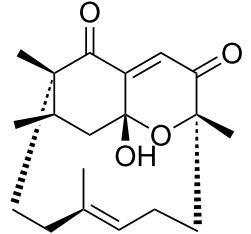

$299,94 \%$
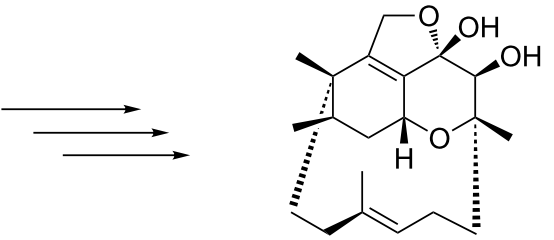

$(+)$-phomactin A (300)

Scheme 89: The Kornblum-DeLaMare rearrangement used in the synthesis of phomactin A.

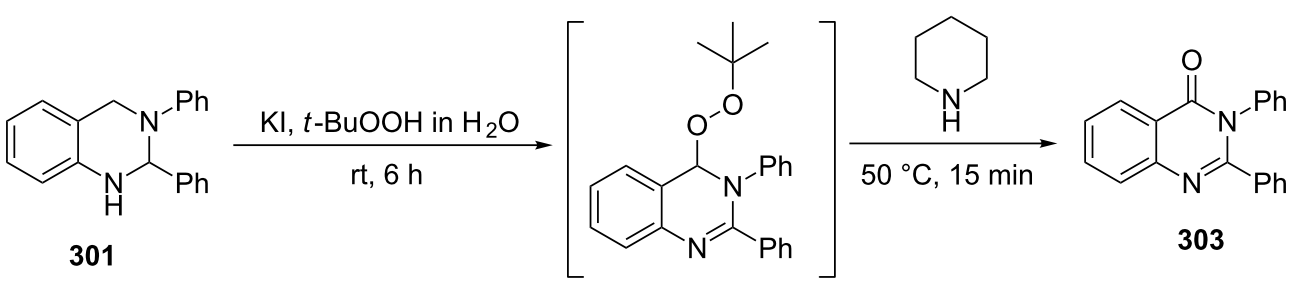

302

Scheme 90: The Kornblum-DeLaMare rearrangement in the synthesis of $3 \mathrm{H}$-quinazolin-4-one $\mathbf{3 0 3}$.

of $\mathrm{Co}$ (salen) and TBHP under mild conditions. The transformation involved the combination of a tandem radical reaction and a Kornblum-DeLaMare rearrangement in a one-pot process (Scheme 94) [374].

The readily available compounds styrenes 314 , amines 318 and perfluoroalkyl iodides 319 were transformed into $(Z)-\beta$-perfluoroalkylenaminones $\mathbf{3 2 0}$ via a $\mathrm{Co}(\mathrm{acac})_{2} / \mathrm{TBHP}$-promoted multi- component radical reaction involving sequential fluoroalkylation and Kornblum-DeLaMare rearrangement (Scheme 95) [375].

Peroxy products resulted from the reaction of styrenes 314, ethyl diazoacetate (321), and TBHP underwent a Kornblum-DeLaMare rearrangement with formation of $\gamma$-ketoester 322 (Scheme 96) [376]. 

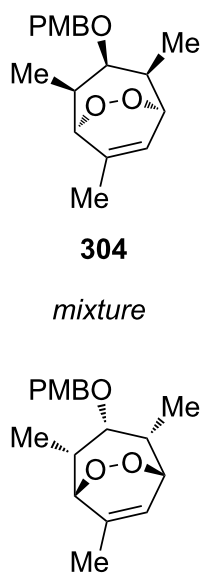

306
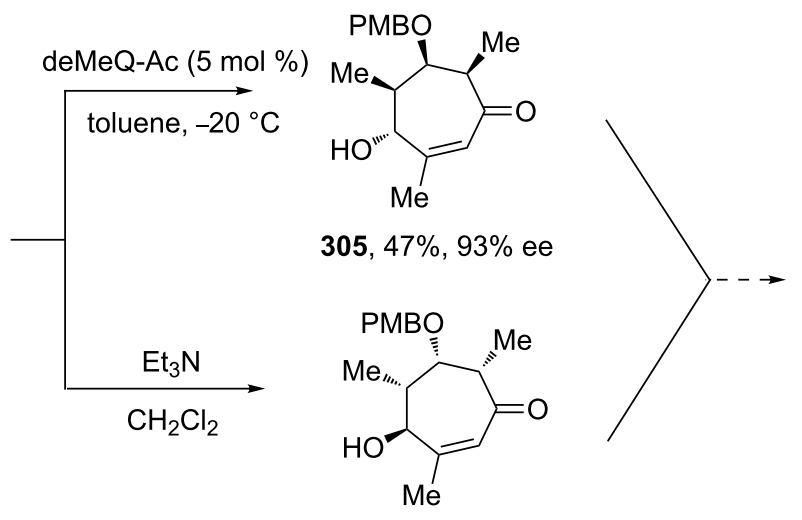

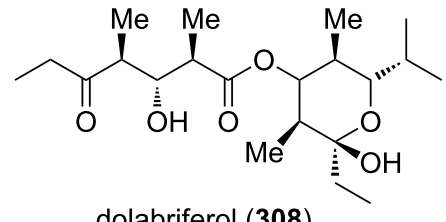

dolabriferol (308)

$307,92 \%, 91 \%$ ee

Scheme 91: The Kornblum-DeLaMare rearrangement in the synthesis of dolabriferol (308).<smiles>[R]c1ccc[nH]c1=O</smiles>
$\mathrm{O}_{2}, h v, \mathbf{T}(2.5$ equiv $)$
$\underset{\operatorname{TPP}(0.1 \mathrm{~mol} \%)}{\stackrel{\mathrm{PhCF}_{3},-25^{\circ} \mathrm{C}}{\longrightarrow}}$

309, $\mathrm{R}=\mathrm{Et}, \mathrm{Bn}, \mathrm{CH}_{2} \mathrm{OEt}$, $\mathrm{CH}_{2} \mathrm{OBn}, \mathrm{c}-\mathrm{Hex}$

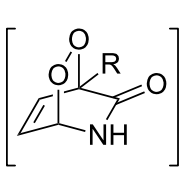

310

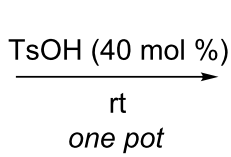

one pot<smiles>[R][C@]1(O)C=CC(=O)NC1=O</smiles>

311

yield $30-99 \%$ ee $69-86 \%$

Scheme 92: Sequential transformation of 3-substituted 2-pyridones 309 into 3-hydroxypyridine-2,6-diones 311 in one pot

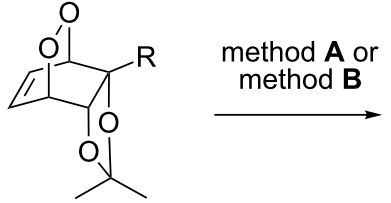

312<smiles>[R][C@]12OC(C)(C)O[C@H]1C(=O)C=C[C@H]2O</smiles>

313

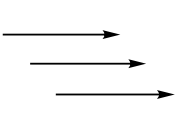<smiles>CC(C)(C)OC[C@]1(O)[C@@H](O)C=CC(=O)[C@H]1O</smiles>

$(+)$-zeylenol

A: thiourea, $\mathrm{CH}_{2} \mathrm{Cl}_{2} / \mathrm{MeOH}$, rt, $90 \mathrm{~min}$

B: iPrNEt, $\mathrm{CH}_{2} \mathrm{Cl}_{2}$ or DMF

$\begin{array}{lll} & \text { A } & \text { B } \\ \mathrm{R}=\mathrm{CH}_{2} \mathrm{OBz} & 99 \% & 94 \% \\ \mathrm{R}=\mathrm{CH}_{2} \mathrm{OTBDMS} & 99 \% & 97 \% \\ \mathrm{R}=\mathrm{COOMe} & - & 100 \%\end{array}$

Scheme 93: The Kornblum-DeLaMare rearrangement of peroxide 312 into hydroxy enone 313

The Kornblum-DeLaMare rearrangement is a final step in the total synthesis of the diterpenoids amphilectolide (326) and sandresolide B (328) from a common furan building block 324, which was synthesized from 323. Amphilectolide was obtained through a photooxygenation of $\mathbf{3 2 5}$ in the presence of diiso- propylethylamine (DIEA), followed by a one-pot reduction of the intermediate peroxide with sodium borohydride. Sandresolide B was prepared from 327 using tetraphenylporphyrin as a photosensitizer and DBU as a base in 51\% yield over two steps (Scheme 97) [377]. 


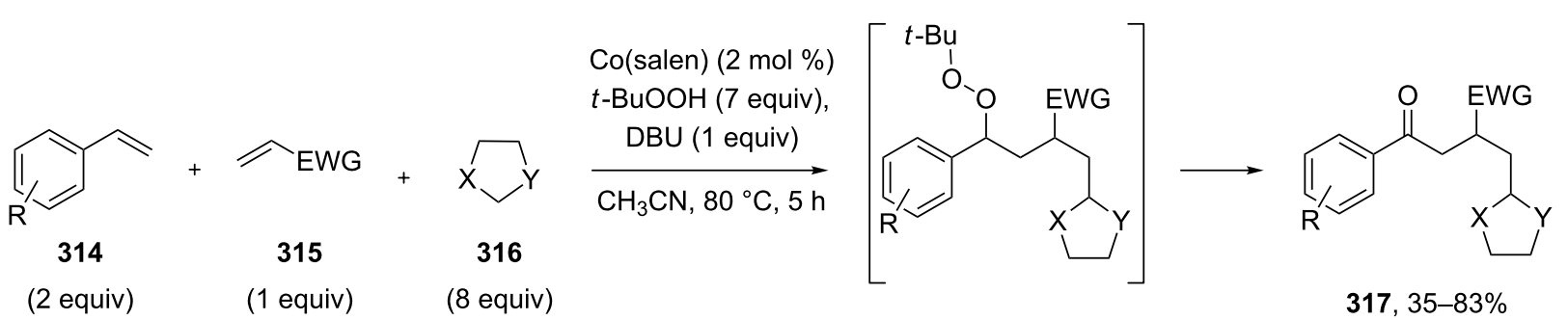

$\mathrm{R}=$ alkyl, OMe, $\mathrm{H}, \mathrm{CN}, \mathrm{Hal}, \mathrm{X}, \mathrm{Y}=\mathrm{O}, \mathrm{CH}_{2}, \mathrm{~S}$

NHBoc, OBn, Oallyl, OTs

EWG: COOEt, $\mathrm{P}(\mathrm{O})(\mathrm{OEt})_{2}$

Scheme 94: The Kornblum-DeLaMare rearrangement in the synthesis of polyfunctionalized carbonyl compounds 317.

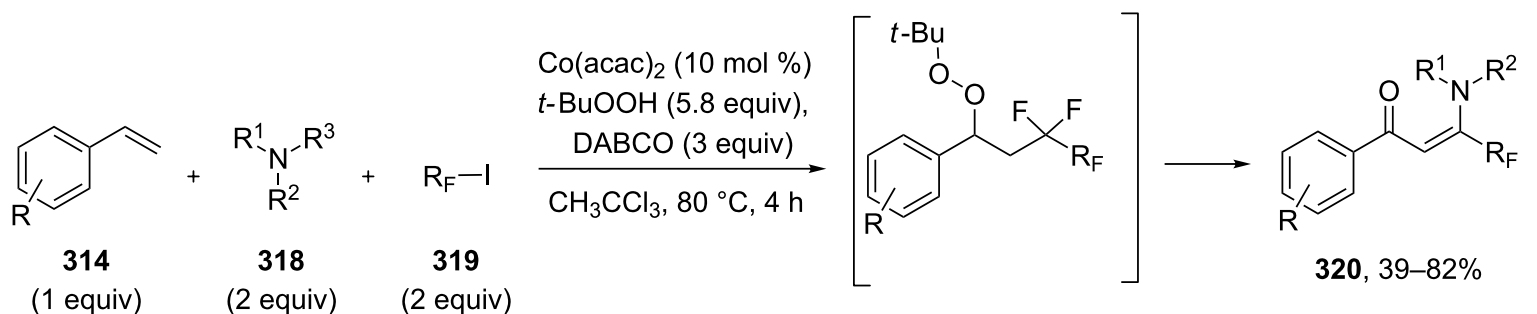

$\mathrm{R}=$ alkyl, OMe, $\mathrm{H}$,

$\mathrm{CN}, \mathrm{Hal}, \mathrm{NHBoc}$

Scheme 95: The Kornblum-DeLaMare rearrangement in the synthesis of (Z)-- $\beta$-perfluoroalkylenaminones 320
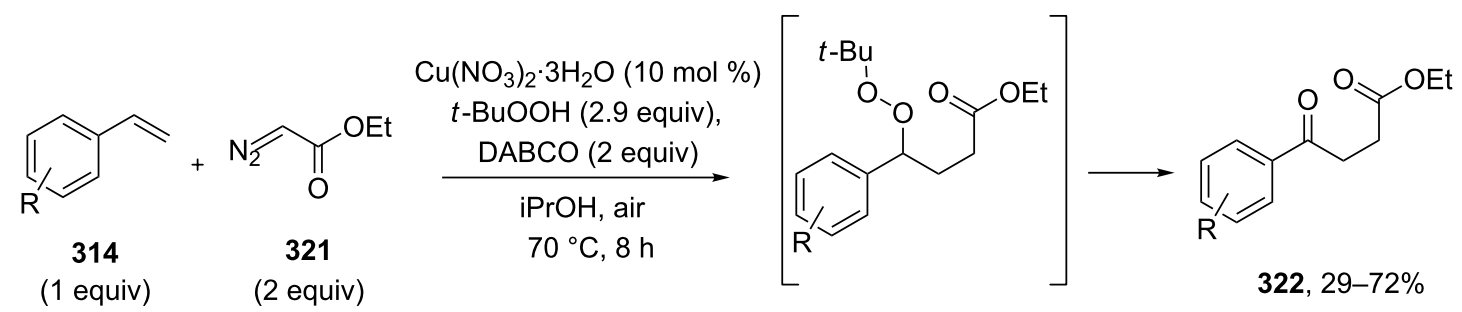

$\mathrm{R}$ = alkyl, OMe, H, CN, Hal,

NHBoc, OBn, Oallyl, OTs

Scheme 96: The Kornblum-DeLaMare rearrangement in the synthesis of $\gamma$-ketoester 322.

The total synthesis of the natural products hainanolidol (331) and harringtonolide (332) includes a DBU-promoted Kornblum-DeLaMare rearrangement of endoperoxide 329 to ketone 330 (Scheme 98) [378].

The reaction of the sodium salts of 1,3-dicarbonyl compounds 333, 334 with endoperoxides 263 and 261a in the presence of an organocatalyst affords the trans-fused butyrolactones 339 and $\mathbf{3 4 0}$ in high yield. The reaction proceeds via the formation of bicycles 335,336 in the case of method A and 337, 338 in the case of method B (Scheme 99) [379].

The leucosceptroid A (341) produced leucosceptroid C (343) and its diastereomer in 78\% yield ( $1: 1 \mathrm{dr})$ under the base-induced reduction of the initial endoperoxide intermediate. Irradiation of a solution of leucosceptroid A (341) in an oxygen-saturated dichloromethane solution containing a catalytic amount of tetraphenylporphyrin (TPP) and N,N-diisopropylethylamine 


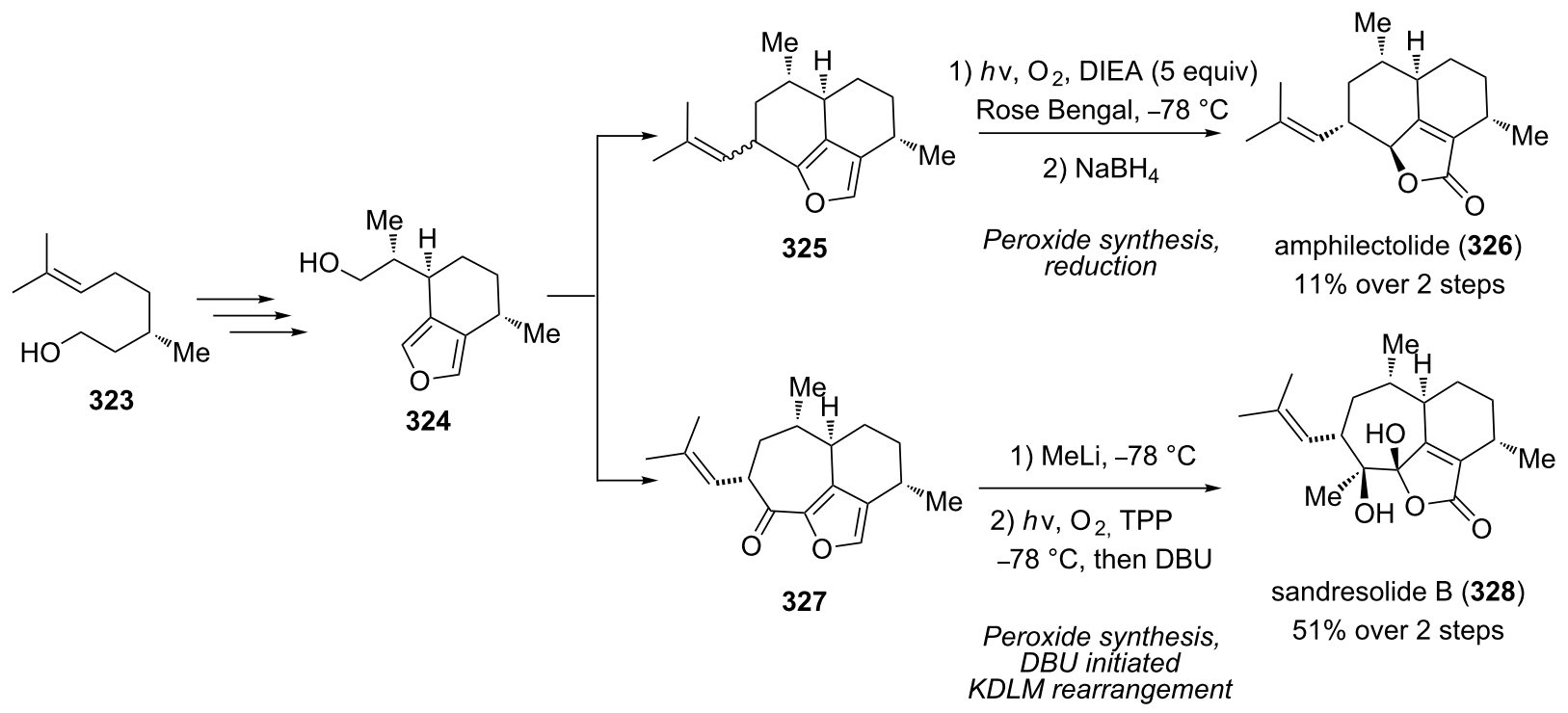

Scheme 97: The Kornblum-DeLaMare rearrangement in the synthesis of diterpenoids 326 and 328.

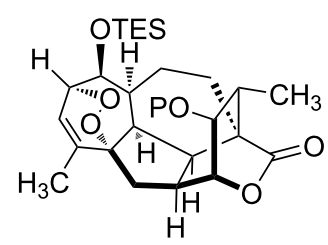

329

$\mathrm{P}=\mathrm{TBS}$

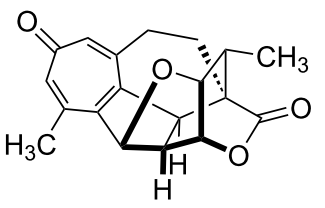

harringtonolide (332)

$52 \%$

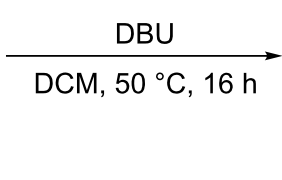

$\mathrm{Pb}(\mathrm{OAc})_{4}$

benzene, $90{ }^{\circ} \mathrm{C}$

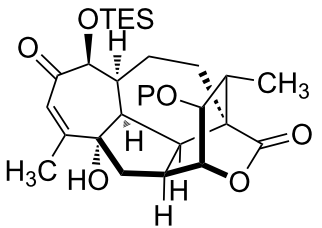

330

$\mathrm{TsOH}, \mathrm{CDCl}_{3}$,

$80{ }^{\circ} \mathrm{C}, 12 \mathrm{~h}$

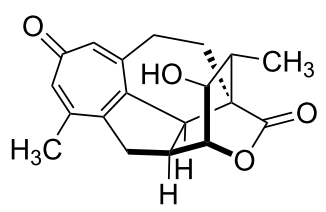

hainanolidol (331)

$85 \%$ over 2 steps

Scheme 98: The synthesis of natural products hainanolidol (331) and harringtonolide (332) from peroxide 329.

cleanly produced 344 ( $85 \%$ yield). The latter compound represents the base-promoted Kornblum-DeLaMare rearrangement product of endoperoxide 342 (Scheme 100) [380].

It is worth mentioning that the synthesis of 4-hydroxycyclopentenone $\mathbf{3 4 3}$ and litsaverticillols was achieved in a similar way in other works [381-384].

\subsection{Dakin oxidation of arylaldehydes or aceto-}

\section{phenones}

Generally, the Dakin oxidation is a reaction, in which $o$ - or $p$-hydroxylated benzaldehydes or acetophenones 345 react with hydrogen peroxide in the presence of a base to form $o$ - or p-dihydroxybenzene 346 and carboxylate 347 (Scheme 101) $[385,386]$. 


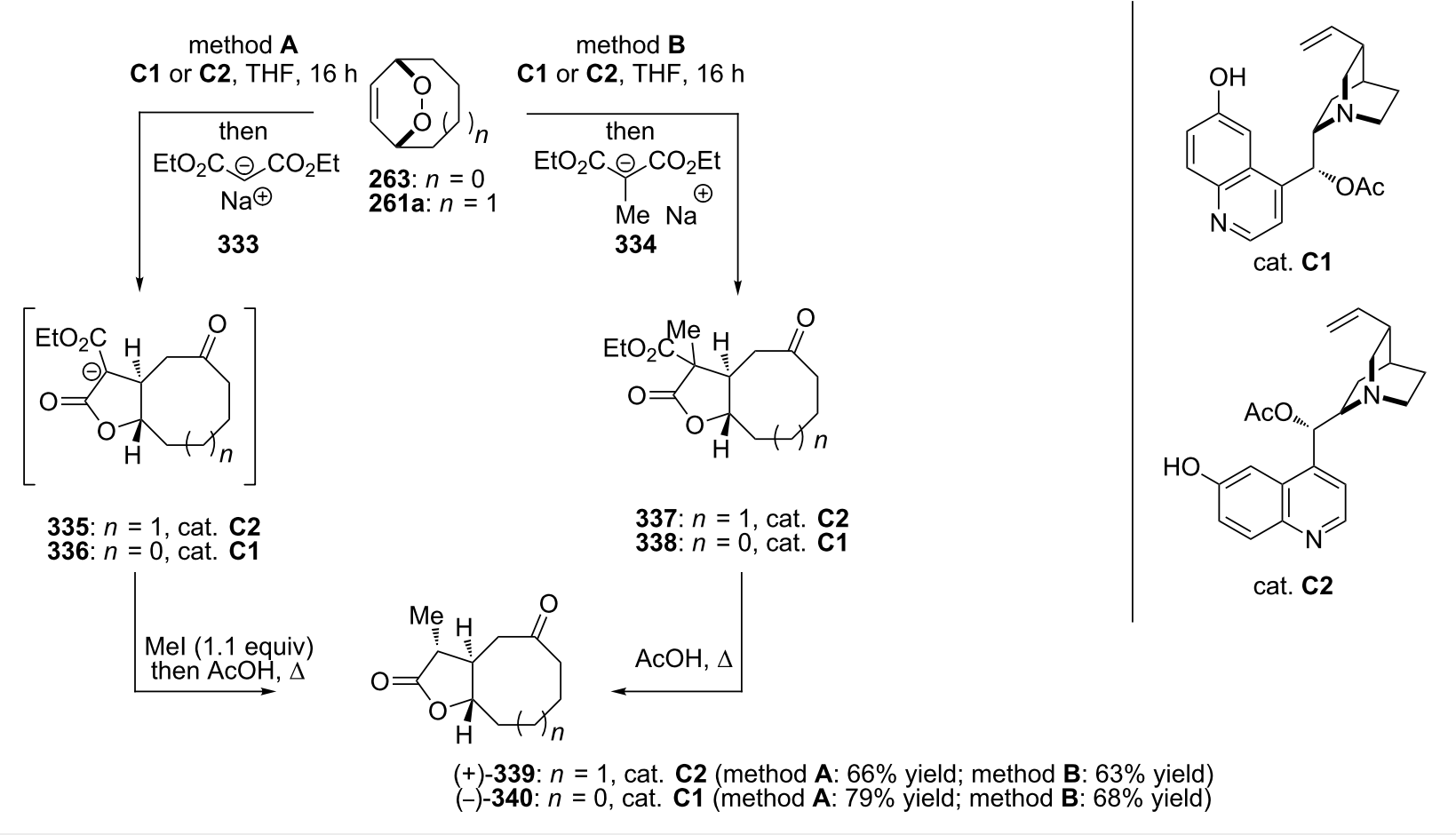

Scheme 99: The synthesis of trans-fused butyrolactones 339 and 340.

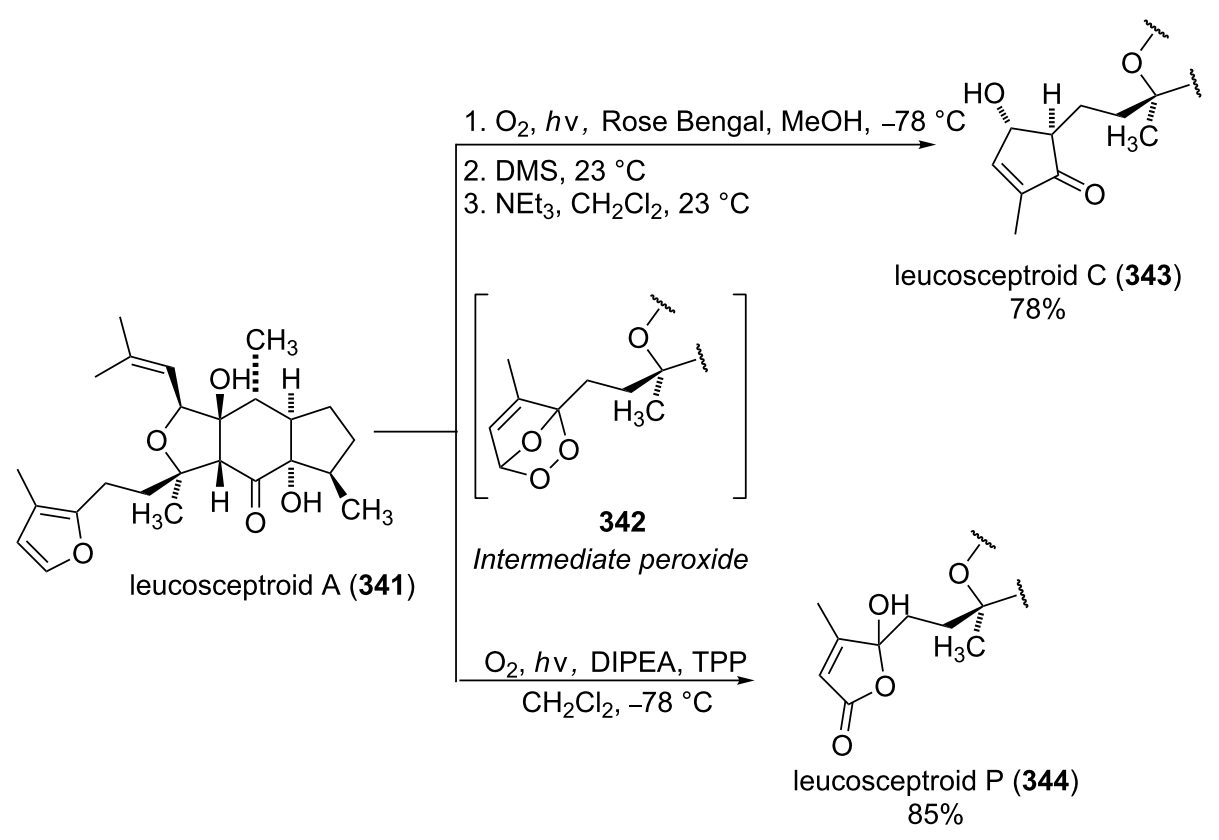

Scheme 100: The synthesis of leucosceptroid C (343) and leucosceptroid P (344) via the Kornblum-DeLaMare rearrangement.

Actually, the Dakin oxidation is a special case of the Baeyer-Villiger oxidation. Mechanistically, the Dakin oxidation starts with the nucleophilic addition of a hydroperoxide anion to the carbonyl carbon atom of benzaldehyde (348) to form intermediate $\mathbf{3 4 9}$ followed by its rearrangement to phenyl ester 350. The subsequent nucleophilic addition of a hydroxide anion to the carbonyl group of phenyl ester $\mathbf{3 5 0}$ yields intermediate 351, which undergoes a rearrangement accompanied by the elimination of phenoxide anion $\mathbf{3 5 2}$ and carboxylic acid 353. Then, the phenoxide anion 352 deprotonates the carboxylic 
<smiles>[R]C(=O)O[Na]</smiles>

Scheme 101: The Dakin oxidation of arylaldehydes or acetophenones.

acid 353 to produce $p$-dihydroxybenzene (354) and the corresponding carboxylate anion 355 (Scheme 102) [385,387].

The nucleophilic addition of the hydroperoxide to the carbon atom of a carbonyl group and the [1,2]-aryl migration are the two rate-determining reaction steps in the Dakin oxidation process [387]. The total rate of the Dakin oxidation depends on the nucleophilicity of the hydroperoxide, the electrophilicity of the carbonyl carbon atom, the nature of alkyl substituents in the proximity of the carbonyl group, the existence of other functional groups in the aromatic ring, and the alkalinity of the reaction mixture. Generally, hydroxybenzaldehydes are more reactive in the Dakin oxidation than hydroxyacetophenones. This is due to the fact, that the carbonyl carbon atom of ketones is less electrophilic than the carbonyl carbon atom of an aldehyde. Under weakly basic conditions, $o$-hydroxybenzaldehydes and $o$-hydroxyacetophenones are oxidized more rapidly than $p$-hydroxybenzaldehydes and $p$-hydroxyacetophenones, whereas $m$-hydroxybenzaldehydes and $m$-hydroxyacetophenones are unreactive [387]. Electron-donating substituents in the ortho and para positions of the aromatic ring enhance the electron density on the migrating carbon atom thus promoting the [1,2]aryl migration and accelerating the oxidation. Electron-donating substituents in the meta position have little effect on the electron density on the migrating carbon atom. Electron-with- drawing substituents in the ortho and para positions of the aromatic ring reduce the electron density on the migrating carbon atom, interfering with the [1,2]-aryl migration. The hydroperoxide anion is a more reactive nucleophile than neutral hydrogen peroxide. The reaction rate of the oxidation of hydroxyphenylaldehydes or ketones increases with increasing $\mathrm{pH}$ value, however, at $\mathrm{pH}$ higher than 13.5 the oxidation does not take place [387].

The efficient oxidation of hydroxylated aldehydes and ketones to hydroquinones and catechols was performed using a complex of urea with hydrogen peroxide as an oxidant [388]. The main advantage of this method is, that the reaction is performed under solvent-free conditions and provides the products in high yields.

A solvent-free Dakin reaction of aromatic aldehydes 356 with $m$-CPBA resulted in corresponding phenols 357 with high yields within a few minutes (Scheme 103) [389].

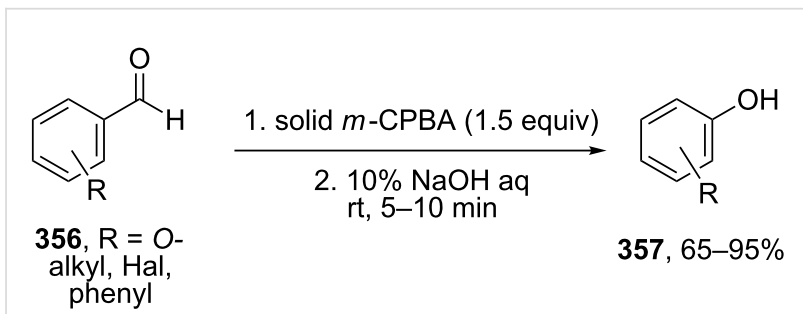

Scheme 103: A solvent-free Dakin reaction of aromatic aldehydes 356.

The phenols 359 were prepared from electron-rich arylaldehydes 358 by a flavin-catalyzed Dakin oxidation under the action of $\mathrm{H}_{2} \mathrm{O}_{2}$ and sodium bicarbonate with high yields (Scheme 104) [390].<smiles>O=Cc1ccc(O)cc1</smiles>

348

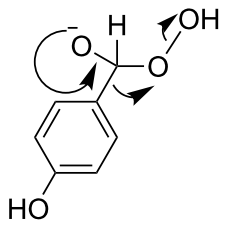

349

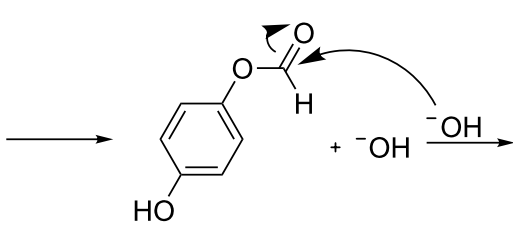

350<smiles>C[C@H](Oc1ccc(O)cc1)[C@@H](C)O</smiles>

351
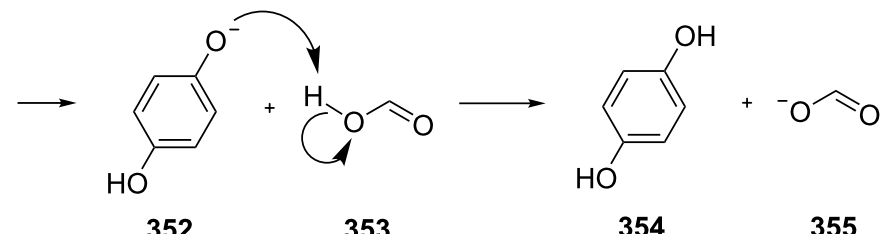

354

355 
<smiles>O=Cc1ccccc1</smiles>

$$
\begin{aligned}
& 360 \text { (10 mol \%) } \\
& \underset{\mathrm{H}_{2} \mathrm{O}_{2} \text { (5 equiv) }}{\mathrm{NaHCO}_{3} \text { (1 equiv) }} \\
& 95 \% \mathrm{MeOH}_{\text {aq, }} \mathrm{rt}
\end{aligned}
$$

358, $\mathrm{R}=\mathrm{O}$-alkyl, $\mathrm{Me}, \mathrm{NO}_{2}$<smiles>Oc1cccc(O)c1</smiles>

$359,75-98 \%$<smiles>[R]c1cc2c(cc1[R])N(CC)C1(OO)C(=O)N(C)C(=O)N(C)C1=N2</smiles>

$\mathrm{R}^{1}=\mathrm{Cl}, \mathrm{F}, \mathrm{H}, \mathrm{OCH}_{3}, \mathrm{CH}_{3}$

$\mathrm{FIOOH}(\mathbf{3 6 0})$

Scheme 104: The organocatalytic Dakin oxidation of electron-rich arylaldehydes 358.

The flavin-catalyzed Dakin oxidation provides a more selective formation of phenols in comparison with the base-catalyzed rearrangement. The Dakin oxidation of arylaldehydes 361 is performed in the presence of molecular oxygen as the oxidant, a flavin organocatalyst and a Hantzsch ester. The oxidation products, catechols and electron-rich phenols 362, were prepared with $0.1-10 \mathrm{~mol} \%$ of catalyst, 1 equiv of the Hantzsch ester, and $\mathrm{O}_{2}$ or air in a stoichiometric amount (Scheme 105) [391].

Dakin reactions of benzaldehydes $\mathbf{3 5 8}$ with $\mathrm{H}_{2} \mathrm{O}_{2}$ were successfully performed in natural feedstock extract 'Water Extract of Banana' (WEB) at room temperature under aerobic conditions in short reaction times. Under these conditions, phenols 359 could be obtained with $90-98 \%$ yields (Scheme 106) [392]. The WEB was prepared by extraction of banana ash with distilled water. The authors suggested that the potassium carbonate and sodium carbonate present in the extract serve as the internal base to promote the Dakin oxidation.

The Dakin oxidation was applied for the synthesis of indolo[2,1-b]quinazolines $\mathbf{3 6 4}$ from indole-3-carbaldehydes 363. In the first step, the oxidation of indole-3-carbaldehydes 363 with further cyclization leads to isatoic anhydrides $\mathbf{3 6 5}$. Then, the anhydrides 365 react with indole-3-carbaldehydes 363 to produce the target indolo[2,1-b]quinazolines 364 (Scheme 107) [393].

The Dakin oxidation is widely used for the synthesis of benzenediols and alkoxyphenols. For example, catechol gener-

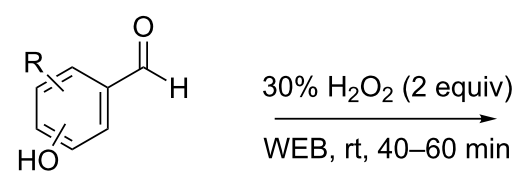<smiles>Oc1cccc(O)c1</smiles>

358, $\mathrm{R}=\mathrm{Hal}, \mathrm{O}$-alkyl, $\mathrm{Me}, \mathrm{NO}_{2}$

$359,90-98 \%$

Scheme 106: The Dakin oxidation of arylaldehydes 358 in water extract of banana (WEB)

ated from $o$-alkoxybenzaldehydes is employed as the starting reagent in the synthesis of catecholamine derivatives [394]. Catechols, for example are substrates in the manufacture of synthetic adhesives and coatings. Their multifaceted reactions with both, organic and inorganic reagents, make catechols widely applied compounds for surface modifications [395].

Vanillin was oxidized under Dakin conditions under formation of 2-methoxyhydroquinone with $97 \%$ yield. This vanillin-derivative was used as a building block in the synthesis of bio-based compounds applicable in polymer field [396].

The Dakin oxidation of mixtures of lignin depolymerization products is an important process for increasing the number of hydroxy groups in arene cycles. Then, these byproducts are glycidylated with mixtures of epoxy monomers. The obtained products are interesting compounds for the synthesis of biobased epoxy thermosets with outstanding thermomechanical indexes [397].<smiles>N#COc1ccccc1C=O</smiles>

361

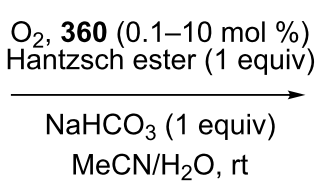

$\mathrm{NaHCO}_{3}(1$ equiv)
$\mathrm{MeCN} / \mathrm{H}_{2} \mathrm{O}, \mathrm{rt}$<smiles>Oc1ccccc1OCc1ccccc1</smiles>

362, 65-91\%<smiles>CCOC(=O)C1=C(C)NC(C)=C(C(=O)OCC)C1C</smiles>

Hantzsch ester 
<smiles>O=Cc1c[nH]c2ccccc12</smiles>

363, $\mathrm{R}=\mathrm{H}, \mathrm{Br}, \mathrm{OMe}, \mathrm{Me}, \mathrm{NO}_{2}$<smiles></smiles>

$364,40-70 \%^{R}$

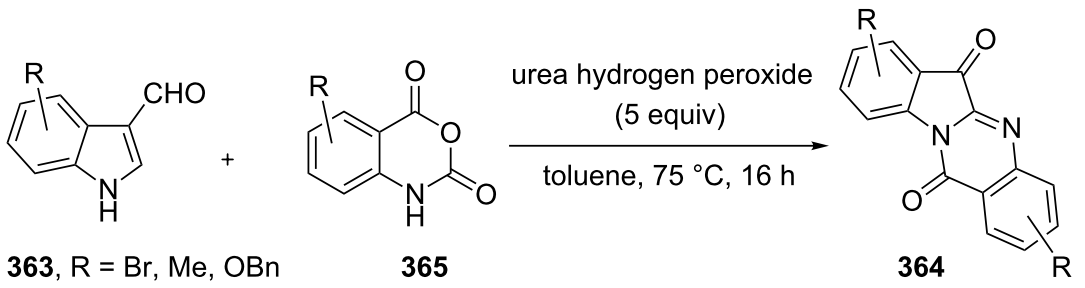

Scheme 107: A one-pot approach towards indolo[2,1-b]quinazolines 364 from indole-3-carbaldehydes 363 through the Dakin oxidation.

Acid-catalyzed Dakin oxidation: The mechanism of Dakin oxidation under mild acidic conditions is similar to the base-catalyzed mechanism. A $30-35 \%$ aqueous $\mathrm{H}_{2} \mathrm{O}_{2} /$ acid system can be employed as the oxidizing agent to synthesize phenols $\mathbf{3 6 7 a - c}$ from benzaldehydes $366 \mathbf{a}-\mathbf{c}$. The oxidation of $\mathbf{3 6 6}$ a using traditional peracids produces a mixture of aryl formate $\mathbf{3 6 8}$ and epoxides $\mathbf{3 6 9}$ and $\mathbf{3 7 0}$ (Scheme 108) and cannot be applied to substrates containing peracid-labile functional groups [398].

The addition of boric acid to the $\mathrm{H}_{2} \mathrm{O}_{2}$ /acid system leads to an increase in the yield of phenols 372a-f even in the case of benzaldehydes 371a-c or acetophenones 371d-f containing electron-donating groups in the meta position or electron-withdrawing groups in the ortho or para positions with respect to the carbonyl group (Table 16) [399].
Presumably, the coordination of the $\mathrm{H}_{2} \mathrm{O}_{2}$-aldehyde adduct 373 by the highly polarized boric acid is responsible for the increased yields of phenols $\mathbf{3 7 2}$. The adduct $\mathbf{3 7 3}$ easily eliminates a borate ion with concerted migration of the aryl group giving phenols 372. The migrating rate of the aryl group is higher in comparison with hydride migration and formation of $\mathbf{3 7 4}$ (Scheme 109).

\subsection{Elbs persulfate oxidation of phenols}

The Elbs oxidation is the oxidation of phenols 375 with potassium persulfate in the presence of alkali hydroxides to form p-hydroquinones 376 (Scheme 110) [400,401].

The Elbs oxidation is a multistep process, which commences by the formation of the phenolate anion 377. This is followed by

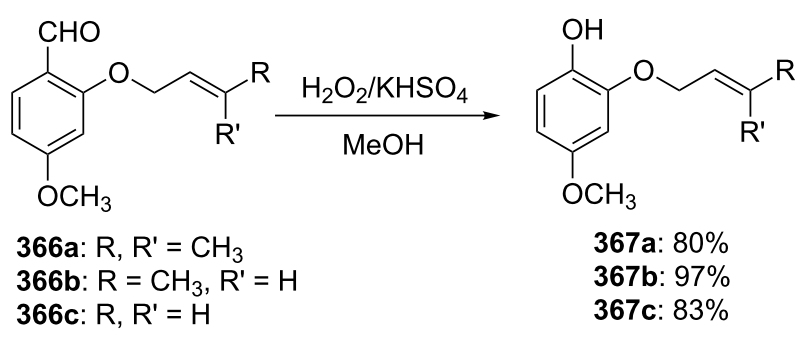<smiles>COc1ccc(OC=O)c(OCC=C(C)C)c1</smiles>

$368,18 \%$<smiles>COc1ccc(OC=O)c(OCC2OC2(C)C)c1</smiles>

$369,30 \%$<smiles>COc1ccc(C=O)c(OCC2OC2(C)C)c1</smiles>

$370,40 \%$ 
Table 16: Acid-catalyzed Dakin oxidation of benzaldehydes $371 \mathrm{a}-\mathrm{c}$ and acetophenones $371 \mathrm{~d}-\mathrm{f}$ by $\mathrm{H}_{2} \mathrm{O}_{2} / \mathrm{H}_{3} \mathrm{BO}$ in $\mathrm{THF}$.<smiles>[R]C(=O)c1ccc([R])c([R])c1[R]</smiles>

371a-f

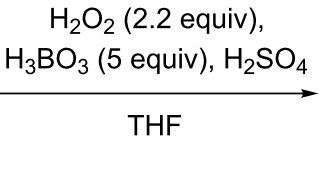

Carbonyl compound
Reaction time, $\mathrm{h}$<smiles>[R7]c1ccc(O)c([R])c1[R]</smiles>

$372 a-f$

\begin{tabular}{cccc}
\hline Compound & Carbonyl compound & Reaction time, $\mathrm{h}$ & Yield, \% 372a-f \\
\hline 371a & $\mathrm{R}^{1}=\mathrm{R}^{2}=\mathrm{R}^{3}=\mathrm{R}^{4}=\mathrm{H}$ & 12 & 74 \\
371b & $\mathrm{R}^{1}=\mathrm{OH}, \mathrm{R}^{2}=\mathrm{R}^{3}=\mathrm{R}^{4}=\mathrm{H}$ & 7 & 80 \\
371c & $\mathrm{R}^{1}=\mathrm{R}^{2}=\mathrm{R}^{4}=\mathrm{H}, \mathrm{R}^{3}=\mathrm{OH}$ & 24 & 90 \\
371d & $\mathrm{R}^{1}=\mathrm{OH}, \mathrm{R}^{2}=\mathrm{R}^{3}=\mathrm{H}, \mathrm{R}^{4}=\mathrm{Me}$ & 36 & 90 \\
371e & $\mathrm{R}^{1}=\mathrm{R}^{2}=\mathrm{R}^{3}=\mathrm{H}, \mathrm{R}^{4}=\mathrm{Me}$ & 24 & 63 \\
371f & $\mathrm{R}^{1}=\mathrm{R}^{2}=\mathrm{H}, \mathrm{R}^{3}=\mathrm{NO}_{2}, \mathrm{R}^{4}=\mathrm{Me}$ & 48 & 60
\end{tabular}

$\underset{\mathrm{Ar}}{\stackrel{\mathrm{O}}{\mathrm{N}}} \stackrel{\mathrm{H}_{\mathrm{H}} \mathrm{O}_{2} / \mathrm{H}_{3} \mathrm{BO}_{3} / \mathrm{H}^{+}}{\mathrm{THF}}$

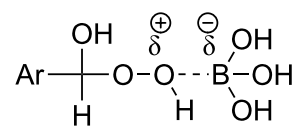

371

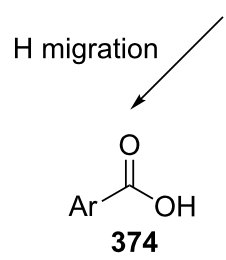

373

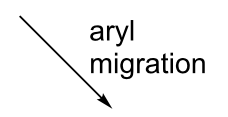

$\mathrm{ArOH}$

372

Scheme 109: Possible transformation paths of the highly polarized boric acid coordinated $\mathrm{H}_{2} \mathrm{O}_{2}$-aldehyde adduct 373 .

the nucleophilic substitution of peroxide oxygen in the peroxydisulfate ion 378 [402] and the resulting sulfoxy group positioned in the para position (compound 379) is hydrolyzed the with formation of $p$-hydroquinone 376 (Scheme 111).

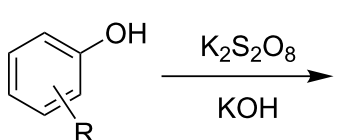

375

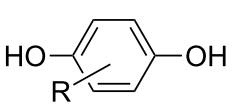

376
$\mathrm{R}=\mathrm{Hal}$, alkyl, $\mathrm{O}$-alkyl, $\mathrm{NO}_{2}, \mathrm{CHO}, \mathrm{COOH}$

Scheme 110: The Elbs oxidation of phenols 375 to hydroquinones.

The oxidation of phenols containing electron-donating substituents to dihydroxybenzenes gives products in higher yields compared with phenols containing electron-withdrawing substituents (Table 17) [403-405].

The main drawback of the persulfate-mediated Elbs oxidation of phenols, are the normally observed moderate conversions and yields. Remarkably, under the above Elbs oxidation conditions 5-hydroxy-2-pyridones $\mathbf{3 8 1}$ were prepared from pyridines 380 with good yields (Scheme 112) [406].

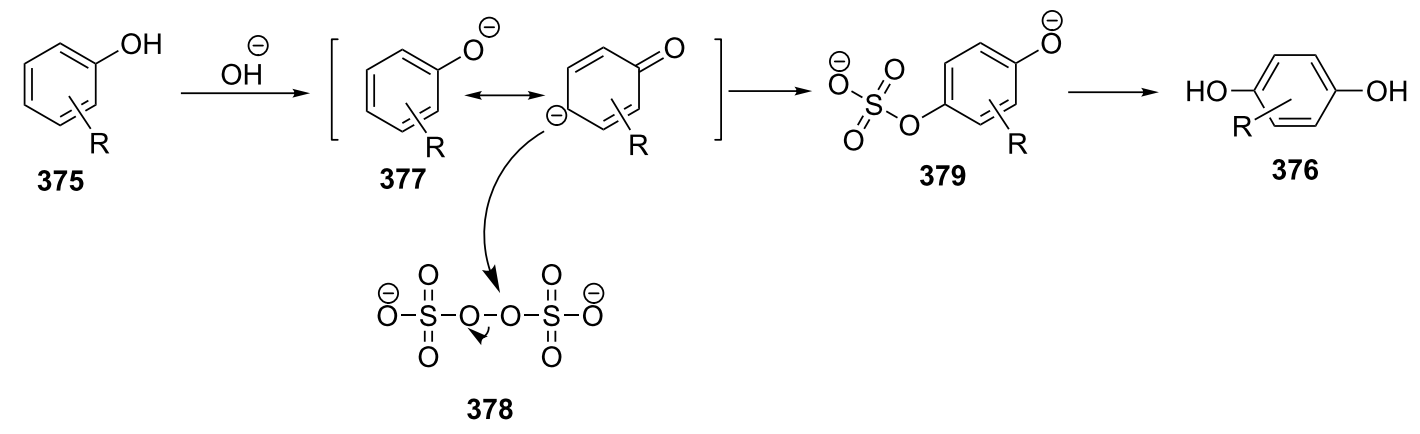




Table 17: Oxidation of phenols 375a-f with potassium persulfate in the presence of alkali.

Scheme 112: Oxidation of 2-pyridones 380 under Elbs persulfate oxi-
dation conditions.

Later, the synthesis of 3-hydroxy-4-pyridone (384) via the Elbs oxidation of 4-pyridone (382) and isolation of 4-pyridone-3sulfate (383) was described (Scheme 113) [407]. The synthesis of 5-hydroxy-6-bromo-2-pyridone was described under similar conditions [408].

\subsection{Schenck and Smith rearrangements}

In 1958, Schenck observed that the storage of $5 \alpha$-hydroperoxide 385 in chloroform for 3 days results in the shift of the OOH group from the $5 \alpha$ to $7 \alpha$ position and a double-bond migration with formation of $\mathbf{3 8 6}$. This reaction is nowadays known as the Schenck rearrangement (Scheme 114) [409-411].

In 1973, Smith discovered another type of rearrangement of allylic hydroperoxides [412]. The $7 \alpha$-hydroperoxide 386 under-<smiles>O=c1cc[nH]cc1</smiles>

382

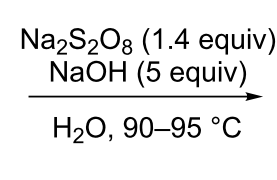

$\underset{\mathrm{H}_{2} \mathrm{O}, 90-95{ }^{\circ} \mathrm{C}}{\mathrm{NaOH}(5 \text { equiv) }}$<smiles>COc1c[nH]ccc1=O</smiles>

383<smiles>O=c1cc[nH]cc1O</smiles>

$\mathbf{3 8 4}$, total yield $13 \%$

Scheme 113: Synthesis of 3-hydroxy-4-pyridone (384) via an Elbs oxidation of 4-pyridone (382).

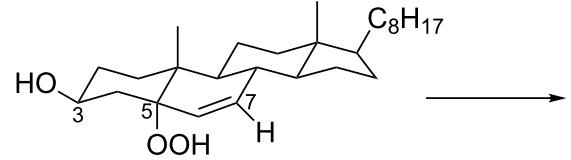

385

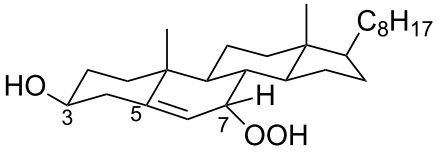

386

Scheme 114: The Schenck rearrangement. 
went a $20-30 \%$ isomerization to the $7 \beta$-hydroperoxide 387 if a solution of $\mathbf{3 8 6}$ in ethyl acetate was kept at $40{ }^{\circ} \mathrm{C}$ for $48 \mathrm{~h}$ (Scheme 115). This process is called the Smith rearrangement.

The mechanisms of these, at first glance simple, reactions were systematically investigated 40 years after their discovery.

Three main pathways for the Schenck rearrangement have been proposed (Scheme 116). Path A involves the cyclization resulting in the formation of a carbon-centered radical. Path $\mathbf{B}$ comprises the formation of a transition state with the electron density distributed over a cyclic system. Path $\mathbf{C}$ proceeds through a dissociation to form an allylic radical and triplet oxygen (Scheme 116) [186,413].

Path A, the initially considered most favorable pathway, was excluded because the isomerization of hydroperoxides $\mathbf{3 8 8}$ and 389 following this route would lead to a $\beta$-scission ring opening of 390 (Scheme 117).

However, this process was not observed and none of the possible carbon-centered radicals $\mathbf{3 9 0}$ was trapped by molecular oxygen [414]. Meanwhile, it is known that the dioxacyclopentyl radical 392 formed from 391 is trapped by oxygen to form hydroperoxide 393 (Scheme 118) [415].

It was hypothesized that the Schenck rearrangement of peroxide 394 proceeds through a cyclic structure 395 according to the pathway shown in Scheme 119 [414].

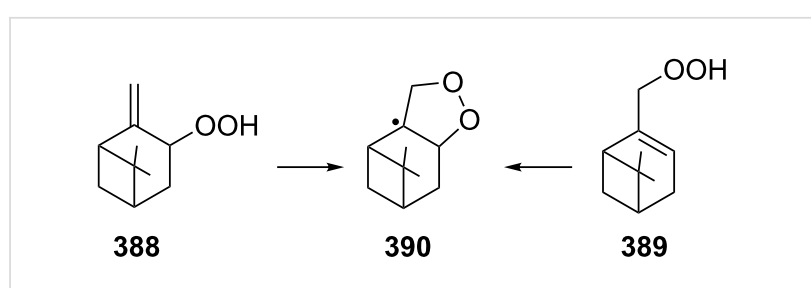

Scheme 117: The isomerization of hydroperoxides 388 and 389.

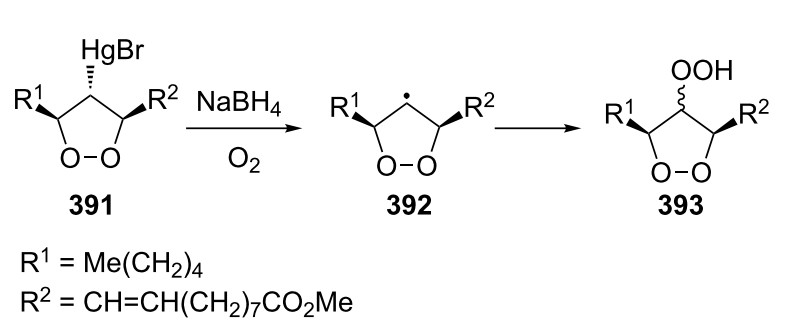

Scheme 118: Trapping of dioxacyclopentyl radical 392 by oxygen

However, this hypothesis was also rejected because the ESR spectra recorded after the photolysis of $5 \alpha$ - and $7 \alpha$-hydroperoxides $\mathbf{3 8 5}$ and $\mathbf{3 8 6}$ showed that the tertiary allylperoxyl radical and secondary allylperoxyl radical are separate and distinct species, and that they do not have the common cyclic structure 395 [416].

In a study using labeled isotope ${ }^{18} \mathrm{O}_{2}$ it was found that the two hydroperoxides $\mathbf{3 9 8}$ and $\mathbf{3 9 9}$ derived from autoxidation of oleic

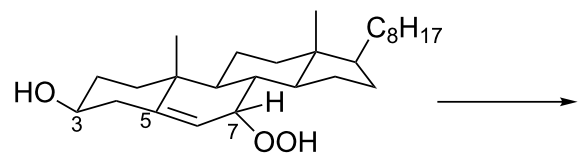

386

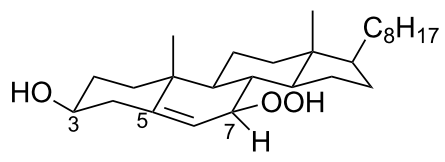

387

Scheme 115: The Smith rearrangement.

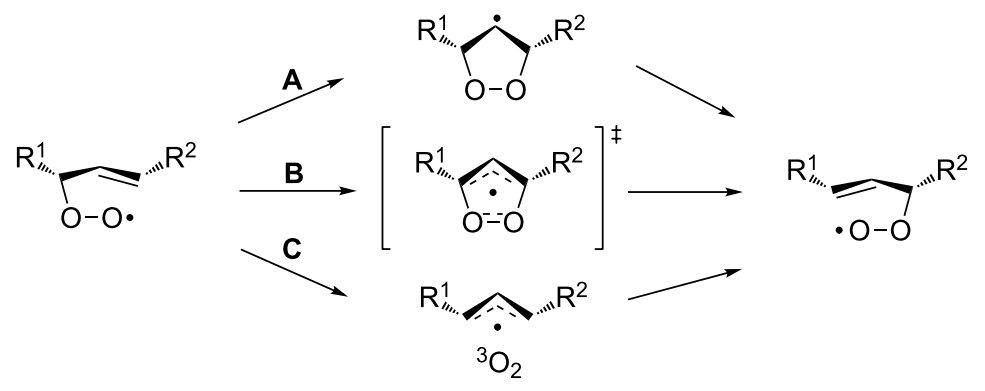


<smiles>[R]C(C)=C([R7])C([R])(O)O</smiles>

394

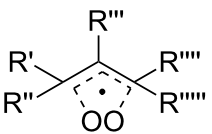

395

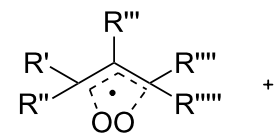

395<smiles>[R]/C(=C(\[R])C([R7])(O)O)C([R])(C)C</smiles>

396

Scheme 119: The hypothetical mechanism of the Schenck rearrangement of peroxide 394

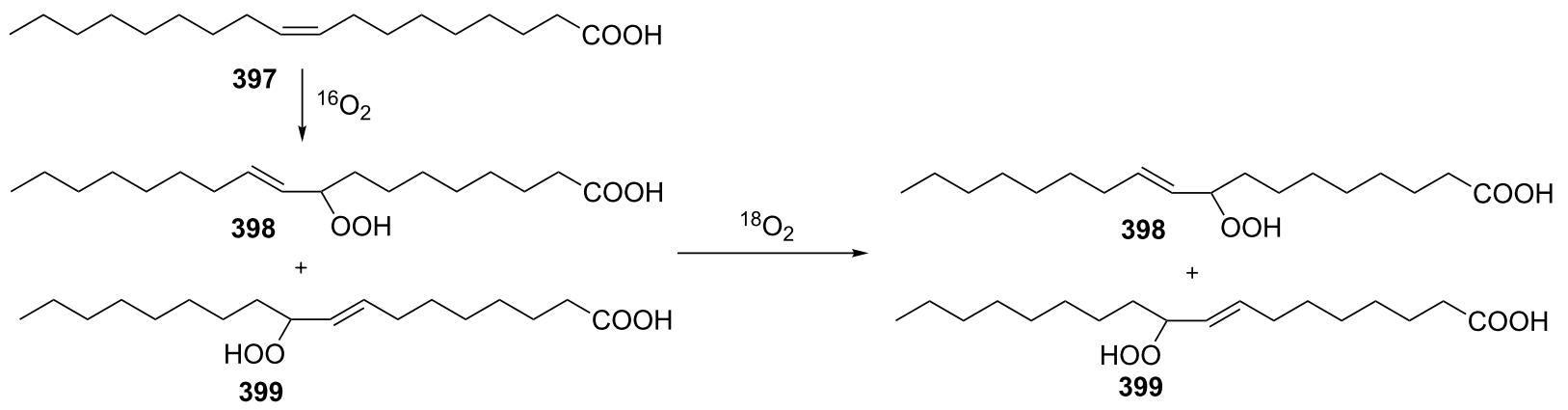

Scheme 120: The autoxidation of oleic acid (397) with the use of labeled isotope ${ }^{18} \mathrm{O}_{2}$.

acid (397) underwent the Schenck rearrangement without incorporating dioxygen from the atmosphere (Scheme 120) [417,418]. Later on, Beckwith and Davies confirmed this fact for cholesterol hydroperoxide [416] and the hydroperoxide generated from valencene [419].

Based on these results, no formation of triplet oxygen occurs in the reaction, thus excluding path $\mathbf{C}$ in Scheme 116. Instead, a cyclic transition state (path $\mathbf{B}$, Scheme 116) became more likely, which was confirmed by the stereoselective rearrangement of optically pure olefinic hydroperoxides [420].

However, the study on the rearrangement of hydroperoxides 398, 399 obtained from oleic acid (397) using stereochemical, oxygen-isotopic labeling and solvent viscosity analyses demonstrated that, in hexane, a small amount of atmospheric oxygen is incorporated into the product. The replacement of the solvent by more viscous dodecane and then by octadecane led to a decreased content of atmospheric oxygen in the final product $[421,422]$. These results provided evidence that the Schenck rearrangement proceeds also through path $\mathbf{C}$ in Scheme 116.

Besides, path $\mathbf{C}$ was also confirmed by the rearrangement of ${ }^{18} \mathrm{O}$-labeled hydroperoxide $\mathbf{4 0 0}$ under an atmosphere of ${ }^{16} \mathrm{O}_{2}$ with formation of isotopomers 401-403 (Scheme 121) [423].

Examples of the Schenck rearrangement are given in Table 18.

The Schenck rearrangement takes also place with allylic hydroperoxides derived from lipids. The rearrangement of the oleatederived allylic hydroperoxides $(S)-\mathbf{4 2 1}$, and (R)-425 involved free radicals includes the oxygen-centered radicals 422,423 , Scheme 121: The rearrangement of ${ }^{18} \mathrm{O}$-labeled hydroperoxide 400 under an atmosphere of ${ }^{16} \mathrm{O}_{2}$. 
426, 427. The $E$-oleate hydroperoxide $(S)$-421 transforms into the corresponding $(R)$-E-product $\mathbf{4 2 4}$ at room temperature with a high $(S) \rightarrow(R)$ stereoselectivity of more than $97 \%$. A decreased selectivity $(\sim 90 \%)$ was observed for product $\mathbf{4 2 8}$ obtained from the $Z$-hydroperoxide $(R)$-425. In this case, the configurational direction of the reaction was $(R) \rightarrow(R)$ (Scheme 122) [438].
The Smith rearrangement is a free-radical chain reaction in which atmospheric oxygen may play a greater role than in the Schenck rearrangement. Apparently, the Smith rearrangement proceeds through a dissociation to the allylic radical and ${ }^{3} \mathrm{O}_{2}$. Presumably, the distance between these active species is large enough to allow an exchange with atmospheric oxygen (Scheme 123). The Schenck and Smith rearrangements are both

Table 18: Examples of the Schenck rearrangement.

Entry Allylic isomer A

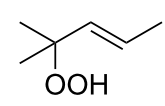

404a
Allylic isomer $\mathbf{B}$<smiles>CC(C)=CC(C)O</smiles>

404b

At $40{ }^{\circ} \mathrm{C}$ in non-polar solvents, an approximately equimolar mixture of $\mathbf{A}$ and $\mathbf{B}$ is formed<smiles>C=C(C)C(O[R6](C)(=O)(O)O)C(C)C</smiles><smiles>CC(=CC(C)C)CO</smiles>

405b

In hexane, $\mathbf{A}$ is rearranged to an equilibrium mixture of $\sim 80 \% \mathbf{A}$ and $\sim 20 \% \mathbf{B}$<smiles>CCCCCCCCCCCCCCCCC[C@@H](O)[C@H](O)C=CCC(=O)OC</smiles>

$406 a$<smiles>CC(=O)CC(O)C=CC(O)c1ccccc1</smiles>

406b

At $60-70{ }^{\circ} \mathrm{C}$ in $\mathrm{C}_{6} \mathrm{H}_{6}$ or MeCN in the presence of TBHN or AIBN within 16-22 $\mathrm{h}$, a 50:50 A:B mixture is formed<smiles>O=C(O)O[C@@]12CCCC=C1CCCC2</smiles><smiles>O[C@H]1CCCC2=C1CCCC2</smiles>

407 a

407b

In $\mathrm{CCl}_{4}$ at $40{ }^{\circ} \mathrm{C}$ for $141 \mathrm{~h}$, the rearrangement proceeds by $80 \%$<smiles>CC(C)(C)O[C@]1(O)C=CCC[C@]1(O)C(=O)O</smiles><smiles>C[C@]12CCCCC1=C[C@H](O)CC2</smiles>

In $\mathrm{CDCl}_{3}$, the rearrangement of $\mathbf{A}$ into $\mathbf{B}$ is completed in $24 \mathrm{~h}$

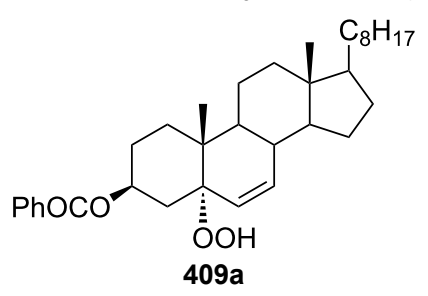

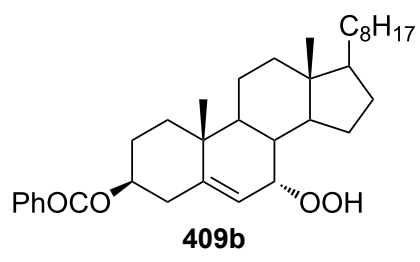

In $\mathrm{CDCl}_{3}$, the rearrangement is completed in $72 \mathrm{~h}$

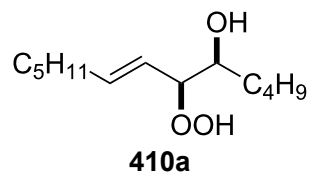<smiles>CCCCCC(O)C=CC(O)[18OH]</smiles>

In $\mathrm{C}_{6} \mathrm{H}_{6}$ in presence of 10 equiv TBHP and $20 \mathrm{~mol} \%$ DTBN at $40{ }^{\circ} \mathrm{C}$ for $16 \mathrm{~h}$, isomers $\mathbf{A}$ and $\mathbf{B}$ are formed in equal amounts 
Table 18: Examples of the Schenck rearrangement. (continued)

8

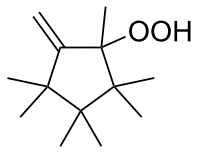

$411 \mathrm{a}$

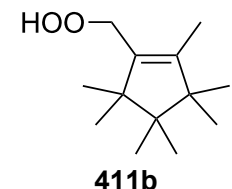

$411 \mathrm{~b}$
In $\mathrm{CDCl}_{3}$ the rearrangement is completed in $48 \mathrm{~h}$<smiles>CC(C)CCCC(C)C1CCC2C3C=C[C@]4(O)C[C@H](O)CCC4(C)C3CCC12C</smiles><smiles>CC(C)CCCC(C)C1CCC2C1CCC1C2C(O)C=C2C[C@@H](O)CCC21C</smiles>

$412 a$

In $\mathrm{CHCl}_{3}$ for $5 \mathrm{~d}$ at room temperature, only partial conversion<smiles>[R]C(C)[C@H]1CC[C@@H](C)[C@H]2CCC(=C)[C@H](O)[C@H]12</smiles>

413a<smiles>[R]C(C)[C@H]1CC[C@@H](C)[C@H]2CCC(COO)=C[C@H]12</smiles>

413b
[430]

In $\mathrm{CDCl}_{3}$ the rearrangement is completed after 3-4 weeks; $\mathrm{R}$ : $\mathrm{CO}_{2} \mathrm{H}, \mathrm{CO}_{2} \mathrm{Me}, \mathrm{CH}_{2} \mathrm{OH}, \mathrm{CH}_{3}$<smiles>[R]C(C)[C@H]1CC[C@@H](C)[C@H]2CCC(=C)[C@H](O)[C@H]12</smiles>

414a<smiles>[R]C(C)[C@H]1CC[C@@H](C)[C@H]2CC(O)C(C)=C[C@H]12</smiles>

414b

In $\mathrm{CDCl}_{3}$ the rearrangement is completed after 2-4 weeks; $\mathrm{R}$ : $\mathrm{CO}_{2} \mathrm{H}, \mathrm{CO}_{2} \mathrm{Me}, \mathrm{CH}_{2} \mathrm{OH}, \mathrm{CH}_{3}$

12<smiles>CC1=CC[C@@H](O)[C@@]2(C)CCCC(C)(C)[C@]2(C)[C@H]1O</smiles>

415a

In $\mathrm{CDCl}_{3}$ the rearrangement is completed after $2 \mathrm{~d}$

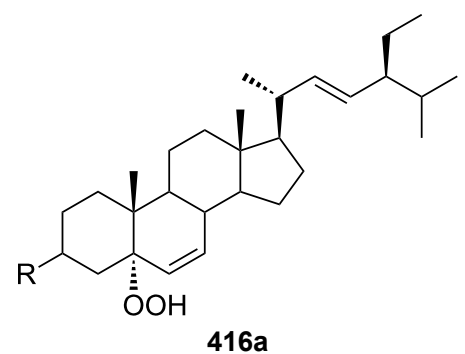<smiles>CC1=CC2(C)[C@@H](C)CCC[C@]2(O)CC1O</smiles>

415b

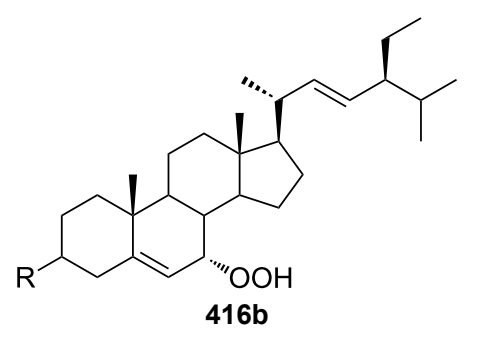

In pyridine for $24 \mathrm{~h}, \mathrm{R}: \mathrm{OH}, \mathrm{CH}_{3} \mathrm{COO}, \mathrm{F}, \mathrm{Cl}$, conversion $12-58 \%$

14<smiles>CC1(OO)C=CCCC1</smiles>

417a<smiles>C=C1CCCCC1OO</smiles> 
Table 18: Examples of the Schenck rearrangement. (continued)

15<smiles>C[C@H](I)[C@H]1CC[C@H]2[C@@H]3C=C[C@]4(O)C[C@@H](O)CC[C@]4(C)[C@H]3CC[C@]12C</smiles>

418a<smiles>C[C@H]([AlH2])[C@H]1CC[C@H]2[C@H]3[C@H](O)C=C4C[C@H](O)CC[C@@]4(C)[C@H]3CC[C@]12C</smiles>

418b

In $\mathrm{CDCl}_{3} / \mathrm{D}_{2} \mathrm{O}$, lyophilized PBS buffer at $\mathrm{pH} 7$ for $20 \mathrm{~h}$, the conversion is $14 \%$<smiles>C=C(C)C(O)C1(O)C2CC3CC(C2)CC1C3</smiles>

419a

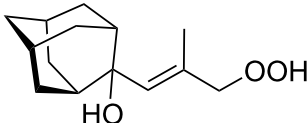

$419 b$

In $\mathrm{CH}_{2} \mathrm{Cl}_{2}$ at $-78{ }^{\circ} \mathrm{C}$ with $\mathrm{BF}_{3} \cdot \mathrm{OEt}_{2}(1 \mathrm{~mol} \%)$
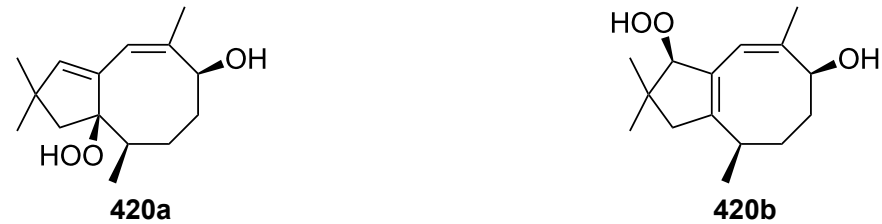

In $\mathrm{MeCN} / \mathrm{H}_{2} \mathrm{O}$, only partial conversion.

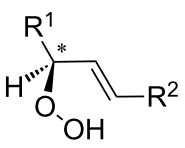

(S) -421

$$
\underset{40^{\circ} \mathrm{C}}{\stackrel{\mathrm{O}_{2}}{\longrightarrow}}
$$<smiles>[R]C1=C[C@H]([R1])OO1</smiles>

422<smiles>[R1]C=CC([R])([O-])[O-]</smiles>

423<smiles>[R1]C=C[C@H]([R])OO</smiles>

(R) -424

$$
\begin{aligned}
& \mathrm{R}_{\mathrm{HOO}} \stackrel{*}{*} \mathrm{R}^{2} \quad \frac{\mathrm{O}_{2}}{40^{\circ} \mathrm{C}} \quad \mathrm{R}^{1} \underset{\mathrm{OO}}{=} \overbrace{\mathrm{H}}^{*} \mathrm{R}^{2} \quad \longrightarrow \\
& \text { (R) -425 } \\
& 426
\end{aligned}
$$

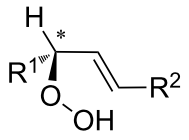

$\mathrm{R}^{1}=\left(\mathrm{CH}_{2}\right)_{7} \mathrm{COOR}$

$\mathrm{R}^{2}=\left(\mathrm{CH}_{2}\right)_{6} \mathrm{CH}_{3}$

Scheme 122: The rearrangement of the oleate-derived allylic hydroperoxides ( $S)-\mathbf{4 2 1}$ and $(R)-\mathbf{4 2 5}$

$$
\begin{aligned}
& \begin{array}{lll}
\text { Schenck } \\
\text { rearrangement }
\end{array} \text { OO. } \\
& \text { Smith } \\
& .00 \curvearrowright \rightleftharpoons \underset{1.00}{.00} \rightleftharpoons
\end{aligned}
$$


a consequence of the reversibility of the reaction of allyl radicals with triplet dioxygen and differ mechanistically in the degree of separation of these two components [186]. There are only a few examples of the Smith rearrangement known and some of them are collected in Table 19.

In diene or triene-containing systems $\mathbf{( 4 3 3 )}$, both the rearrangement and cyclization of allylic peroxyl radicals can take place with formation of 434-436 (Scheme 124) [440].

\subsection{Wieland rearrangement}

In 1911 Wieland performed the decomposition of bis(triphenylmethyl)peroxide (437) under an atmosphere of $\mathrm{CO}_{2}$ in boiling xylene for 10 min and obtained the crystalline product $\mathbf{4 3 8}$ in $70 \%$ yield (Scheme 125) [441].

The mechanism of the Wieland rearrangement involves the following three steps: Initial formation of O-centered radical $\mathbf{A}$, the rearrangement of radical $\mathbf{A}$ into diphenylphen-

\begin{tabular}{|c|c|c|c|c|}
\hline Entry & Allylic isomer B & Allylic isomer $\mathbf{C}$ & Comments & Ref. \\
\hline 1 & $429 a$ & 429b & $\begin{array}{l}\text { In } \mathrm{CDCl}_{3} \text { within } 259 \mathrm{~h} \text {, } \\
\text { approximately } 5 \% \text { of } \mathbf{B} \text { was } \\
\text { transformed into C }\end{array}$ & [427] \\
\hline 2 & ת & $30 \mathrm{~h}$ & $\begin{array}{l}\text { In } \mathrm{CHCl}_{3} \text { at room temperature } \\
\text { within } 150 \mathrm{~h} \text {, the } \mathbf{B}: \mathbf{C} \text { ratio } \\
\text { reached } 1.8: 1\end{array}$ & [439] \\
\hline \multirow[t]{2}{*}{3} & & & $\begin{array}{l}\text { In } \mathrm{CDCl}_{3} \text { at } 40{ }^{\circ} \mathrm{C} \text { within } 3.5 \mathrm{~h} \text {, B } \\
\text { is transformed into } \mathrm{C} \text { by } 20 \% \text {. In } \\
\text { EtOAc at } 40{ }^{\circ} \mathrm{C} \text {, the yield of C } \\
\text { was } 25-30 \%\end{array}$ & [416] \\
\hline & $431 a$ & $31 b$ & $\begin{array}{l}\text { In } \mathrm{CHCl}_{3} \text { after } 5 \mathrm{~d} \text { at room } \\
\text { temperature, only partial } \\
\text { conversion }\end{array}$ & [431] \\
\hline \multirow[t]{2}{*}{4} & & & $\begin{array}{l}\text { In } \mathrm{CDCl}_{3} \text {, the } \mathbf{B}: \mathbf{C} \text { ratio reached } \\
1: 1.5\end{array}$ & [439] \\
\hline & $432 a$ & 432b & & \\
\hline
\end{tabular}

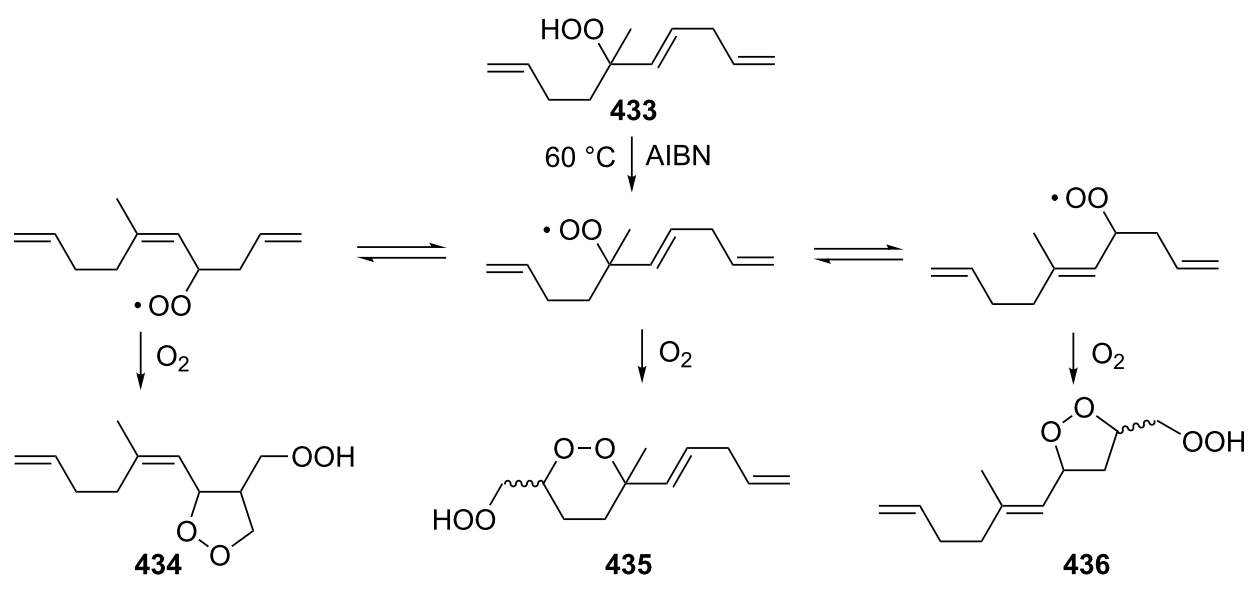

Scheme 124: The rearrangement and cyclization of 433 . 
<smiles>c1ccc(C(OOC(c2ccccc2)(c2ccccc2)c2ccccc2)(c2ccccc2)c2ccccc2)cc1</smiles>

437<smiles>C1CCCCC1</smiles><smiles>[2H]C([O])(c1ccccc1)c1ccccc1</smiles>

A

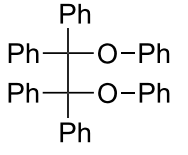

438

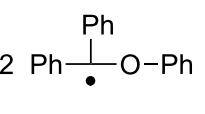

C

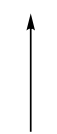

Scheme 125: The Wieland rearrangement

oxymethyl radical $\mathbf{C}$, and the dimerization of radical $\mathbf{C}$ $[442,443]$.

Radical 1,2-aryl migrations from silicon or germanium to oxygen is similar to the Wieland rearrangement. The thermal decomposition of either bis(triphenylsilyl) $\mathbf{4 3 9}$ or bis(triphenylgermyl) $\mathbf{4 4 1}$ peroxides leads to the rearranged products $\mathbf{4 4 0}$, 442 in high yields (Scheme 126) [444,445].

\section{Unnamed rearrangements of organic peroxides and related processes}

2.1 Protic acid-catalyzed rearrangements of organic peroxides and related processes

The oxidative transformation of cyclic ketones 58d and 443a-d in the reaction with hydrogen peroxide in alcohols in the presence of sulfuric acid proceeds through the formation of geminal dihydroperoxides 444a-e. The latter compounds are oxidized to dicarboxylic acids $\mathbf{4 4 5 a - e}$ followed by their transformation into the corresponding dicarboxylates 446a-e, rather than formation of lactones via the Baeyer-Villiger reaction (Scheme 127) [446].

This transformation requires the following key conditions to proceed: a reaction temperature higher than $80^{\circ} \mathrm{C}$, the $\mathrm{H}_{2} \mathrm{SO}_{4}$ concentration in the range of $0.2-1.0 \mathrm{~mol} / \mathrm{L}$, and a molar ratio of hydrogen peroxide/ketone in the range of 5-10. The corresponding dibutyl esters were prepared in $53-70 \%$ yields by oxidation in butanol, which keeps the temperature in the range of 98-106 ${ }^{\circ} \mathrm{C}$ (Table 20).

In a study on the hydroxylation of compounds containing a double bond to the corresponding $\alpha$-glycols, the tungstic acidcatalyzed reaction of cyclohexene (447) with $90 \%$ hydrogen peroxide in methanol, ethanol, or isopropanol afforded the cor-

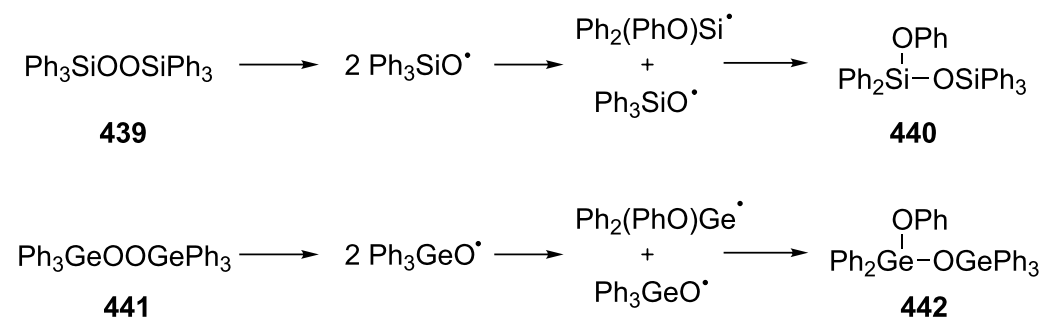

Scheme 126: The rearrangement of bis(triphenylsilyl) 439 or bis(triphenylgermyl) 441 peroxides

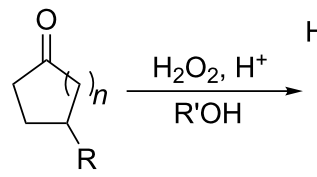

58d, 443a-d<smiles>[R]C1[CH]C(OO)(OO)CC1</smiles>

$444 a-e$<smiles>[R]C(CC(=O)O)CC(=O)O</smiles>

445a-e<smiles>[R]OC(=O)CC([R])C([R])C([R])=O</smiles>

446a-e

58d: $n=3, \mathrm{R}=\mathrm{H}$;

443a: $n=2, \mathrm{R}=\mathrm{Me}$;

443b: $n=2, \mathrm{R}=t-\mathrm{Bu}$;

443c: $n=4, \mathrm{R}=\mathrm{H}$

443d: $n=8, \mathrm{R}=\mathrm{H}$

$\mathrm{R}^{\prime}=\mathrm{Et}, \mathrm{Pr}, \mathrm{Bu}$ 


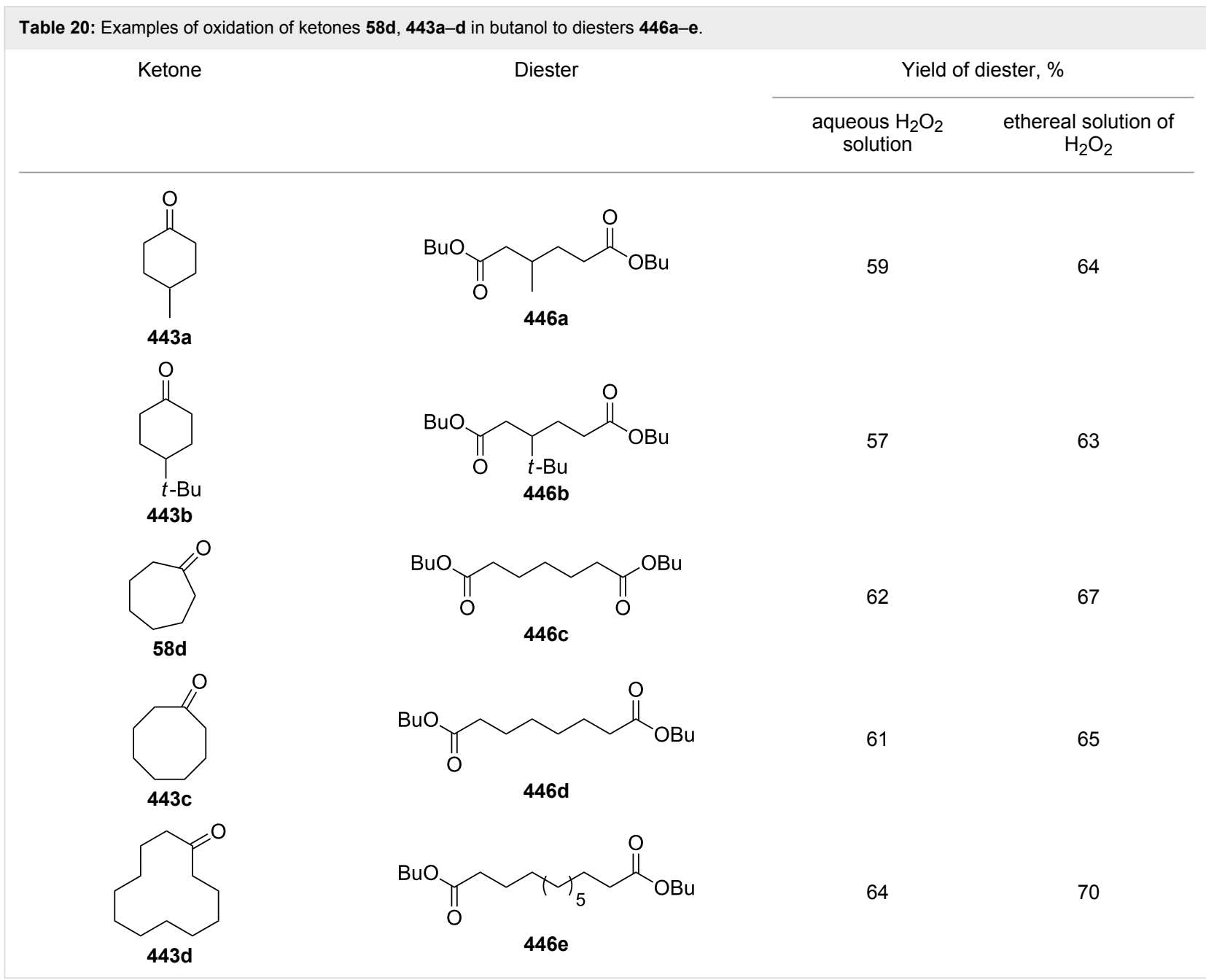

responding 2-alkoxycyclohexanols $\mathbf{4 4 8 a - c}$ in 70, 41, and 21\% yields, respectively, as well as the trans-1,2-cyclohexanediols 449a-d (Scheme 128) [447].<smiles>C1=CCCCC1</smiles>

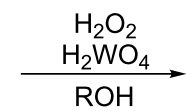

447<smiles>[R]O[C]1CCCCC1O</smiles>

448a: $70 \%$

448b: $41 \%$

448c: $21 \%$

448d: $0 \%$<smiles>OC1CCCCC1O</smiles>

449a: $16 \%$

449b: $36 \%$

449c: $44 \%$

449d: $50 \%$
Scheme 128: The hydroxylation of cyclohexene (447) in the presence of tungstic acid.

A detailed study on the hydroxylation of cyclohexene (447) in tert-butanol using 30\% hydrogen peroxide showed that in this reaction the formation and rearrangements of 2-hydroperoxyalkanols $\mathbf{4 5 1}$ is involved. The treatment of 2-hydroperoxycyclohexanol (451) with acetone afforded the cyclic peroxide $\mathbf{4 5 2}$.
The acid-catalyzed rearrangement of the peroxide $\mathbf{4 5 2}$ gave dialdehyde 453, which further transformed into aldehyde $\mathbf{4 5 4}$. The isolation and characterization of the latter compound was crucial to an understanding of the oxidation of olefins to aldehydes under the action of hydrogen peroxide (Scheme 129).

The study of the reactions of various unsaturated molecules with hydrogen peroxide demonstrated that the reaction of butenylacetylacetone 455 with $\mathrm{H}_{2} \mathrm{O}_{2}$ at $\mathrm{pH} 5-6$ at $38-40{ }^{\circ} \mathrm{C}$ produces 2-methyl-3-hexenoic acid (457). Other possible products 456 resulting from a double-bond oxidation reaction were not observed. Apparently, the formation of carbanion $\mathbf{A}$ is the driving force of this reaction. Carbanion $\mathbf{A}$ transforms into the symmetrical dihydroxyperoxide $\mathbf{B}$, which subsequently rearranges through a deacetoxylation to finally afford 2-methyl3-hexenoic acid (457) (Scheme 130) [448].

The oxidation of bridged 1,2,4,5-tetraoxanes 458 upon heating in an acidic medium in the presence of $\mathrm{H}_{2} \mathrm{O}_{2}$ is leading to esters 459 (Scheme 131) [449]. 


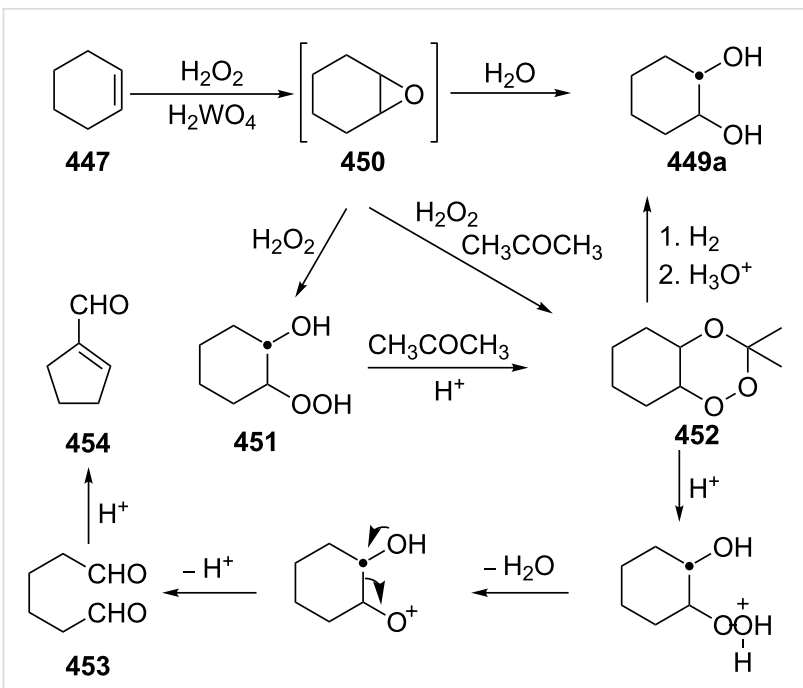

Scheme 129: The oxidation of cyclohexene (447) under the action of hydrogen peroxide.

It is assumed that the reaction of tetraoxanes $458 \mathbf{a}-\mathbf{f}$ proceeds as an acid-catalyzed oxidative transformation, similar to the Baeyer-Villiger and Hock rearrangements, to yield intermediate $\mathbf{A}$. This is further transformed into esters 459a-f through the oxidation of the $\mathrm{CH}$ group and esterification (Scheme 132).

In another study [450], the rearrangement of isomeric ozonides was described. Here, the ozonides $460 \mathbf{a}, \mathbf{b}$ were interconverted and rearranged into the tricyclic monoperoxide 461 under the action of phosphomolybdic acid (PMA). This result is attributable to the protic acid nature of PMA as well as its ability to form peroxo compounds containing $\mathrm{M}-\mathrm{O}-\mathrm{O}$ groups that influence the direction of the reaction (Scheme 133).

The observed interconversion of ozonides may be useful for the interpretation of the data on the ozonolysis of unsymmetrical unsaturated compounds.

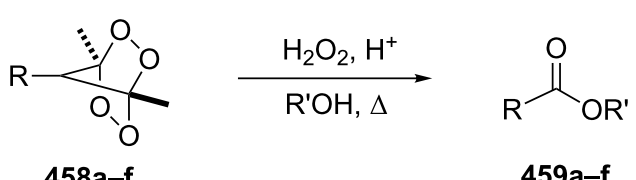

a: $\mathrm{R}=\mathrm{CH}_{2} \mathrm{C}_{6} \mathrm{H}_{5} ; \mathrm{R}^{\prime}=n-\mathrm{Bu} ;$ yield $86 \%$

b: $\mathrm{R}=0-\mathrm{OMeC}_{6} \mathrm{H}_{4} \mathrm{CH}_{2} ; \mathrm{R}^{\prime}=n-\mathrm{Bu} ;$ yield $73 \%$

c: $\mathrm{R}=p-\mathrm{NO}_{2} \mathrm{C}_{6} \mathrm{H}_{4} \mathrm{CH}_{2} ; \mathrm{R}^{\prime}=n-\mathrm{Bu} ;$ yield $67 \%$

d: $\mathrm{R}=p-\mathrm{MeC}_{6} \mathrm{H}_{4} \mathrm{CH}_{2} ; \mathrm{R}^{\prime}=n-\mathrm{Bu} ;$ yield $83 \%$

e: $\mathrm{R}=$ adamantyl; $\mathrm{R}^{\prime}=n-\mathrm{Bu}$; yield $88 \%$

f: $\mathrm{R}=\mathrm{R}^{\prime}=n-\mathrm{Bu} ;$ yield $75 \%$

Scheme 131: The oxidation of bridged 1,2,4,5-tetraoxanes.

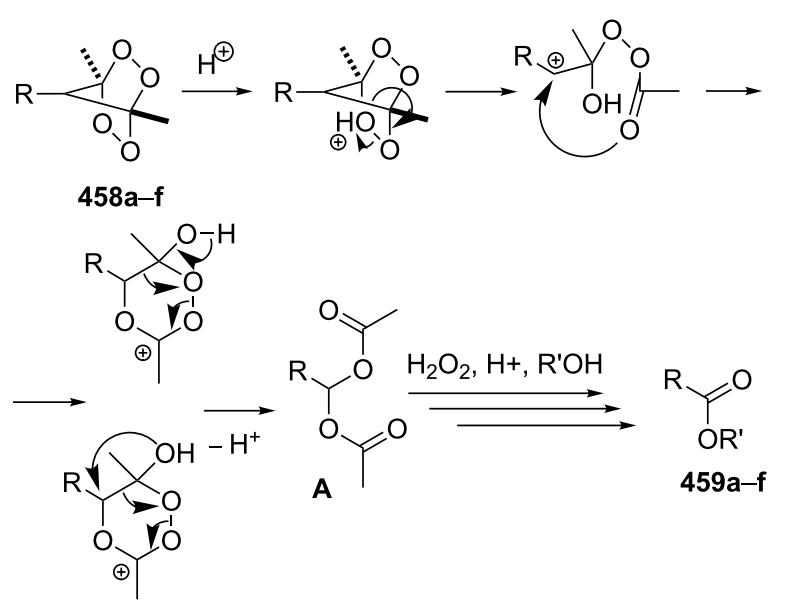

Scheme 132: The proposed mechanism for the oxidation of bridged 1,2,4,5-tetraoxanes.

Carboxylic acids 464 were prepared through a camphorsulfonic acid-catalyzed oxidative rearrangement of a 1,2-dioxolane intermediate 463 prepared from malondialdehydes 462 and $\mathrm{H}_{2} \mathrm{O}_{2}$ (Scheme 134) [451].<smiles>CCC(O)C(O)C(C(C)=O)C(C)=O</smiles><smiles>CCC1OC1C(C)=O</smiles>

456, possible products of the double bond oxidation were not observed<smiles>CCC=CC(C)C(=O)OCC(C)=O</smiles>

$$
457
$$

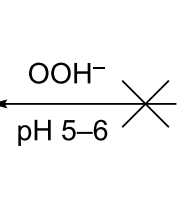<smiles>CCC=CC(C(C)=O)=C(C)O</smiles>

455

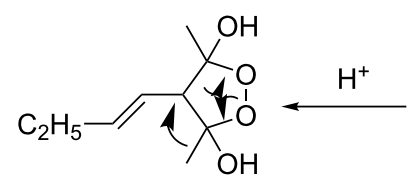

B<smiles>CCCCCCCCCC(C)(O)C(C)(O)O</smiles>

A<smiles>CCC=CC1C(C)([O-])OOC1(C)O</smiles> 


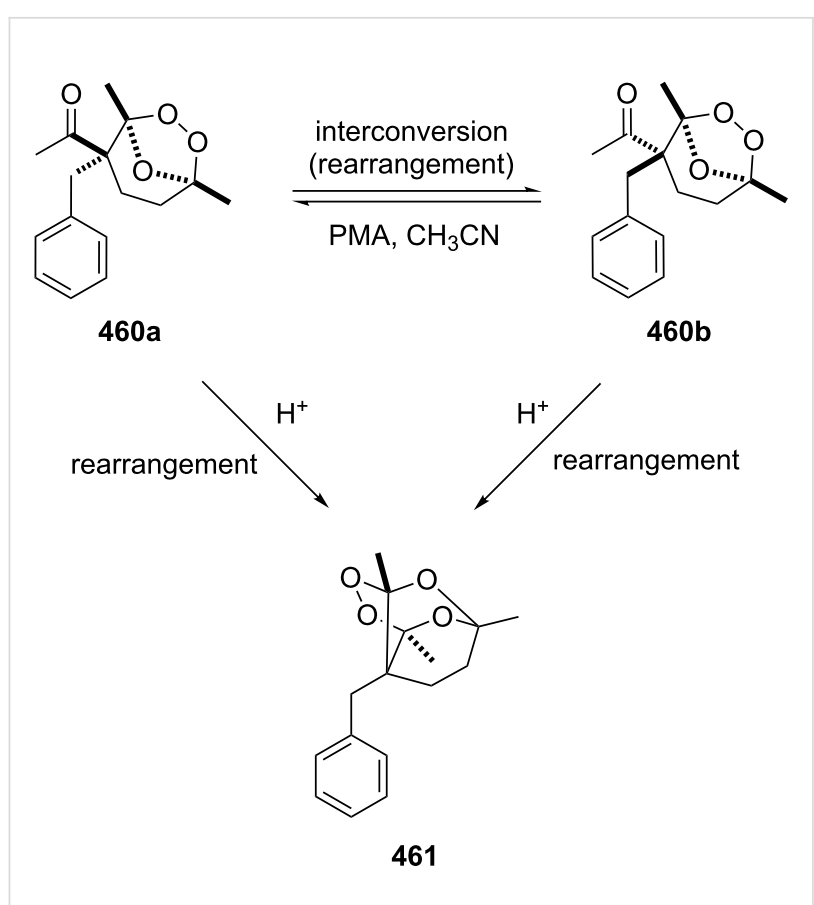

Scheme 133: The rearrangement of ozonides.

\subsection{Lewis acid-catalyzed cleavage of peroxides}

The Lewis acid-catalyzed cleavage of peroxides follows mainly two pathways: the O-O-bond heterolysis to form an oxycarbenium ion 467 accompanied by the migration of the adjacent substituent, and the acid-catalyzed ionization of the $\mathrm{C}-\mathrm{O}$ bond to yield carbenium ion $\mathbf{4 6 8}$. The reaction pathway is mainly determined by the nature of the starting compound and the $\mathrm{C}-\mathrm{O}$ ionization pathway is promoted by the stabilization of the final carbocation, whereas the $\mathrm{O}-\mathrm{O}$-bond heterolysis is facilitated by a high migratory ability of the adjacent groups. The fragmentation of dialkyl peroxides 465 and ozonides 466 mainly depends on the nature of the applied Lewis acid. In this way, $\mathrm{SnCl}_{4}$ and $\mathrm{BF}_{3} \cdot \mathrm{Et}_{2} \mathrm{O}$ facilitate the $\mathrm{O}-\mathrm{O}$-bond heterolysis (A), whereas $\mathrm{TiCl}_{4}$ promotes the $\mathrm{C}-\mathrm{O}$ ionization $\left(\mathrm{S}_{\mathrm{N}} 1\right.$ mechanism) in tertiary peroxides (B). The formation of ketones 469,471 and ester 470 is the result of the Lewis acid-catalyzed decomposition of ozonides through the ionization of peroxide, ionization of alkoxide, or oxygen-oxygen heterolysis (C) (Scheme 135) [452].

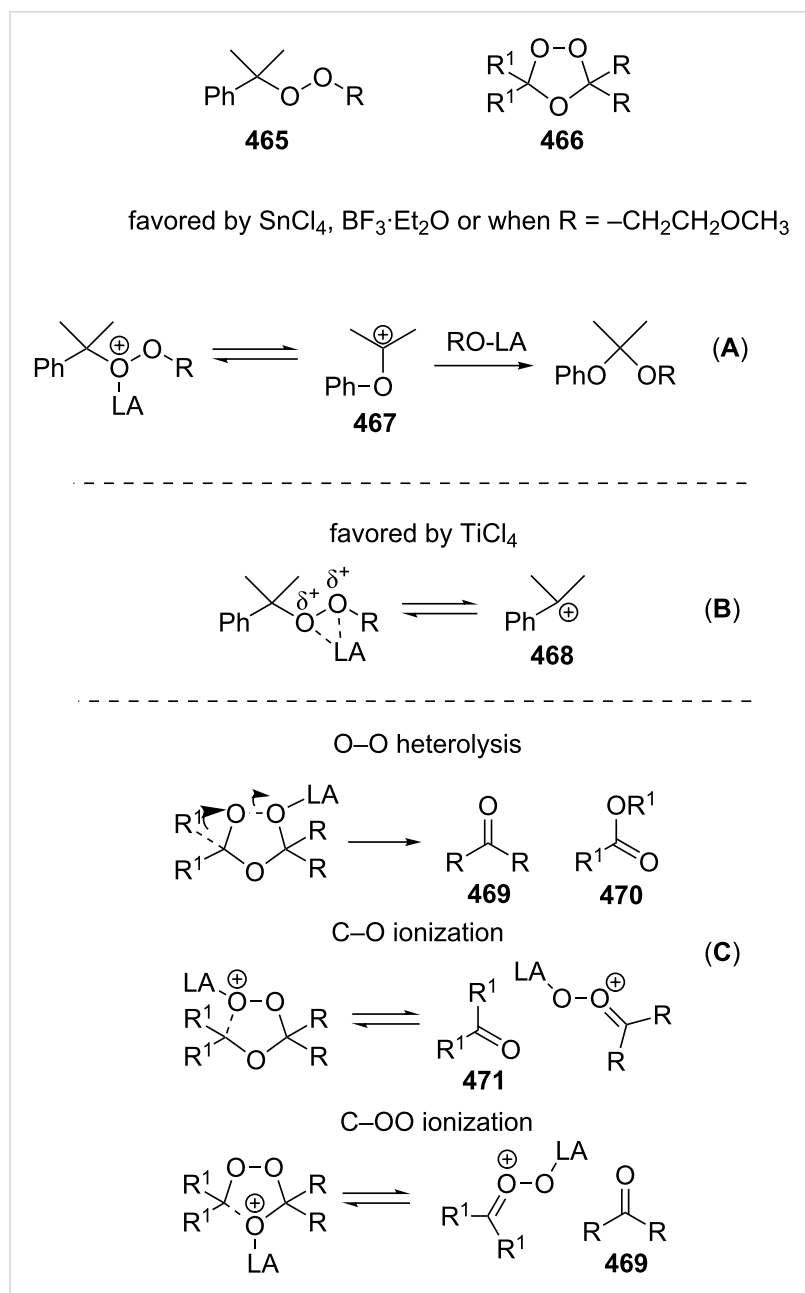

Scheme 135: Pathways of the Lewis acid-catalyzed cleavage of dialkyl peroxides 465 and ozonides 466 .

The $\mathrm{TiCl}_{4}$-promoted rearrangement of (tert-butyldioxy)cyclohexanedienones $\mathbf{4 7 2 a - d}$, which are generated by the rutheniumcatalyzed oxidation of phenols with tert-butyl hydroperoxide, provides an efficient route to 2 -substituted quinones $473 \mathbf{a}-\mathbf{d}$ (Table 21) $[453,454]$. The mechanism of this transformation is depicted in Scheme 136.

In the first step, the coordination of dienone $\mathbf{4 7 2}$ to the Lewis acid gives rise to cation $\mathbf{4 7 4}$. The second step involves a 1,2-<smiles>[R]C([R])(C=O)C=O</smiles>

462

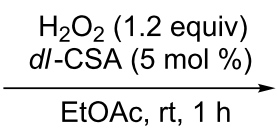

$\mathrm{R}^{1}, \mathrm{R}^{2}=$ alkyl, aryl, $\mathrm{CH}_{2}$ OTBDPS, propargyl, allyl, etc.

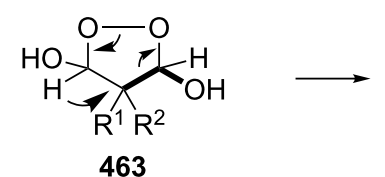<smiles>[R]C([R])C(=O)O</smiles>

$464,79-94 \%$ 
Table 21: $\mathrm{TiCl}_{4}$-promoted rearrangement of (tert-butyldioxy)cyclohexanedienones 472a-d.<smiles>[R]C1=CC(=O)C=CC1=O</smiles>

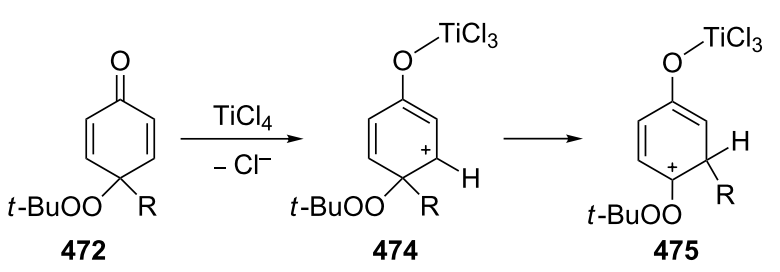<smiles>[R]C1=CC(=O)C(C(C)(C)C(C)(C)C)=CC1=O</smiles>

Scheme 136: The mechanism of the transformation of (tertbutyldioxy)cyclohexanedienones $\mathbf{4 7 2}$. alkyl migration to form cation $\mathbf{4 7 5}$. The subsequent deprotonation of the latter affords aromatic intermediate 476. In the final step, trichloro-tert-butoxytitanium is eliminated from intermediate $\mathbf{4 7 6}$ to produce 2-alkylquinones $\mathbf{4 7 3}$.

The transformation of 4-methyl-4-tert-butyldioxycyclohexadienone 472a into 2-methylbenzoquinone (473a) can be used also for the regioselective synthesis of vitamin $K_{3} \quad 477$ (Scheme 137) [455,456].<smiles>CC1=CC(=O)C(C)=CC1=O</smiles>

a) $\mathrm{BF}_{3} \cdot \mathrm{Et}_{2} \mathrm{O}(10 \mathrm{~mol} \%), \mathrm{HFIP}$, toluene, it or $\mathrm{TiCl}_{4}$ (1.2 equiv), $\mathrm{CH}_{2} \mathrm{Cl}_{2}, \mathrm{rt}$

b) 1,3-butadiene, $\mathrm{Sc}(\mathrm{OTf})_{3}(10 \mathrm{~mol} \%), \mathrm{CH}_{3} \mathrm{NO}_{2}$, rt;

c) $\mathrm{Pd} / \mathrm{C}(10 \mathrm{~mol} \%), \mathrm{CH}_{3} \mathrm{COCH}_{3}$, reflux

Scheme 137: The synthesis of Vitamin $K_{3}$ from $472 a$

The use of $\mathrm{SnCl}_{4}$ or TMSOTf as the catalyst made it possible to prepare trimethylsilyl-substituted cyclic peroxides $479 \mathbf{a}-\mathbf{d}$ and 480a,b in a cis configuration starting from allyltrimethylsilane and bicyclic [2.2.n]endoperoxides 478a-d (Table 22) [457].

The mechanism of this reaction implies that TMSOTf or $\mathrm{SnCl}_{4}$ promote the heterolytic cleavage of the $\mathrm{C}-\mathrm{O}$ bond in $\mathbf{4 7 8 d}$ to form carbocation $\mathbf{4 8 1 d}$, which is then attacked by allyltrimethylsilane through a chair-like transition state $\mathbf{4 8 2 d}$. The subsequent cyclization of $\mathbf{4 8 2} \mathbf{d}$ through the stabilized carbocation 483d affords silyl-substituted peroxide, 1,2-dioxane 479d, containing the substituent $\left(-\mathrm{CH}_{2} \mathrm{SiMe}_{3}\right)$ in the equatorial position (Scheme 138).

The employment of $\mathrm{BF}_{3} \cdot \mathrm{Et}_{2} \mathrm{O}$ as the catalyst for the rearrangement of hydroperoxide $\mathbf{4 8 5}$, which is generated by the oxidation of steroid 484, enables the opening of the $\mathrm{D}$ ring between C-14 and C-16 to form diketone 486 (Scheme 139) [458].

\subsection{Rearrangements and related processes of organic peroxides in the presence of bases}

The base-catalyzed rearrangement of cyclic peroxides $488 \mathrm{a}-\mathbf{g}$, which are prepared by the manganese-catalyzed oxidation of 1and 1,2-disubstituted cyclopropanols $487 \mathbf{a}-\mathbf{g}$, provides a convenient approach to the synthesis of aliphatic and arylaliphatic $\alpha, \beta$-epoxy ketones $489 \mathbf{a}-\mathbf{g}$. The latter compounds are attractive 
Table 22: Conditions of the synthesis of trimethylsilyl-substituted cyclic peroxides (1,2-dioxanes) $479 a-d$ and 480 a,b.

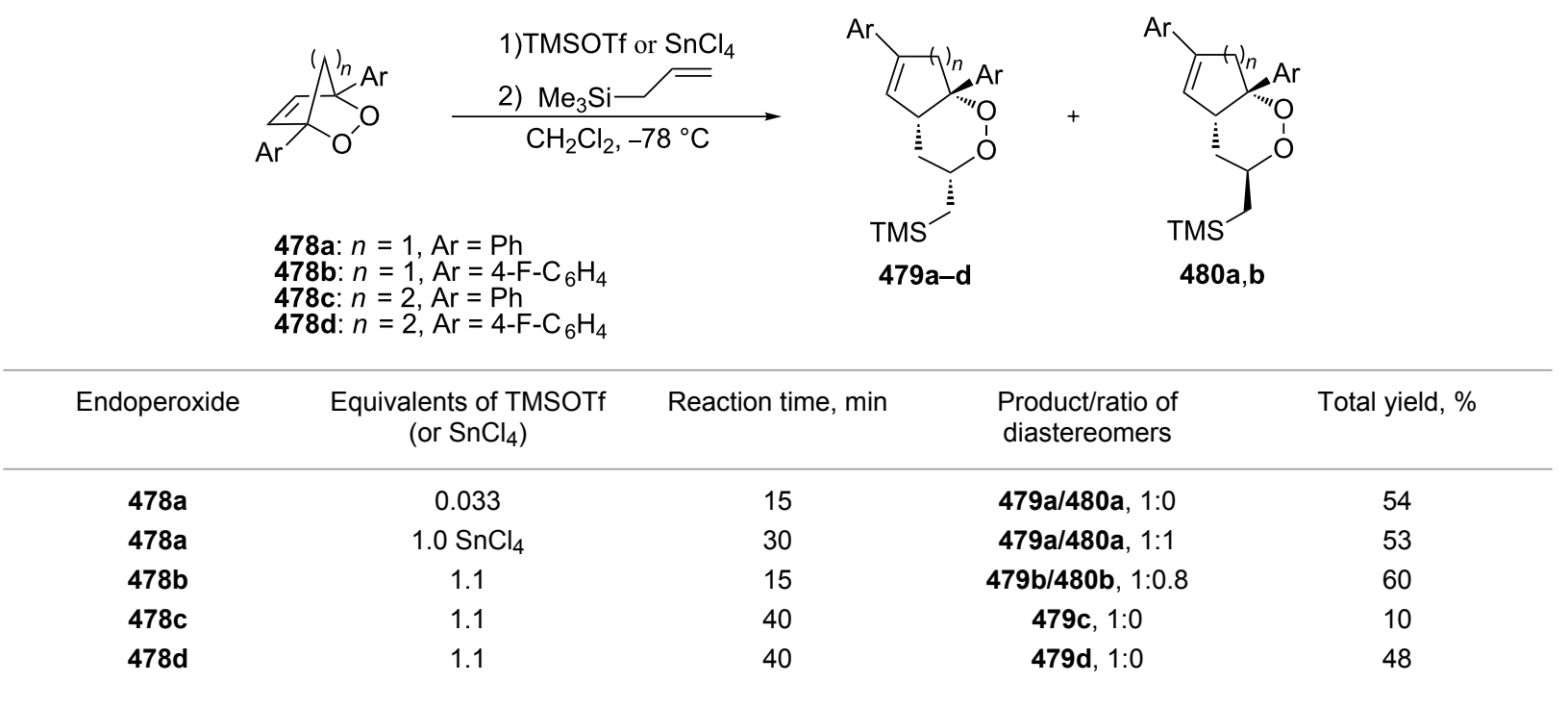
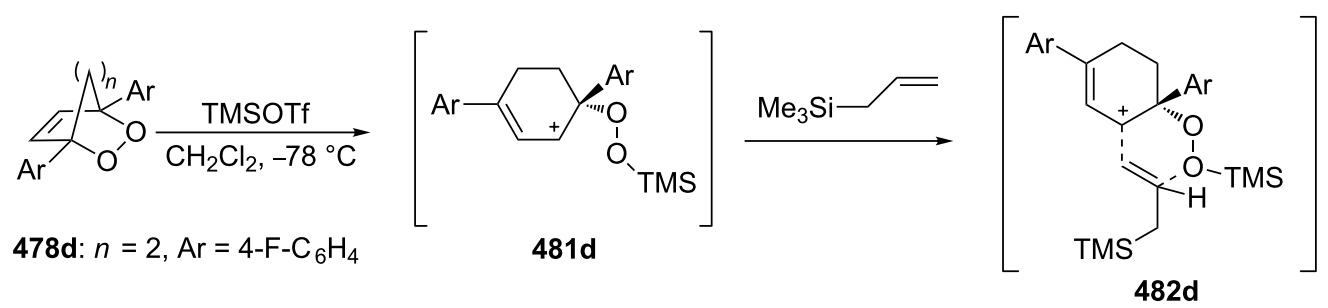

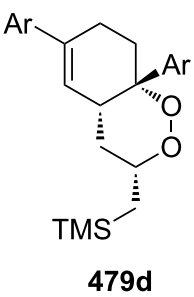
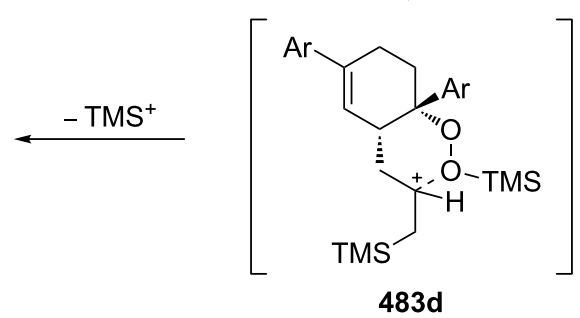

Scheme 138: Proposed mechanism for the transformation of $\mathbf{4 7 8 d}$ into silylated endoperoxide $\mathbf{4 7 9 d}$.

substrates for the synthesis of for example natural compounds (Scheme 140) [459].

Peroxy hemiketals $\mathbf{4 9 1}$ are the starting reagents in the synthesis of epoxides 492 and aldols 493 . Scheme 141 shows the synthesis of epoxides and aldols from inexpensive and readily available $\alpha, \beta$-unsubstituted ketones $\mathbf{4 9 0}$ through the intermediate formation of peroxy hemiketal 491 in the presence of a chiral catalyst [460].
A 1:1 mixture of the diastereomeric hydroperoxides $495 \mathbf{a}-\mathbf{e}$ was synthesized by ozonolysis of $(R)$-carvone (494) and in situ trapping with primary alcohols $\mathrm{ROH}(\mathrm{R}=\mathrm{Me}, \mathrm{Et}, \mathrm{Bu}$, Pent, Oct). Further cyclization of these hydroperoxides 495a-e using the sodium methanolate/MeOH system results in endoperoxides 496a-e exhibiting antimalarial activity (Scheme 142) [461].

The intramolecular rearrangement of 1,2-dioxetanes 497 containing an aromatic electron-donating substituent is accompa- 


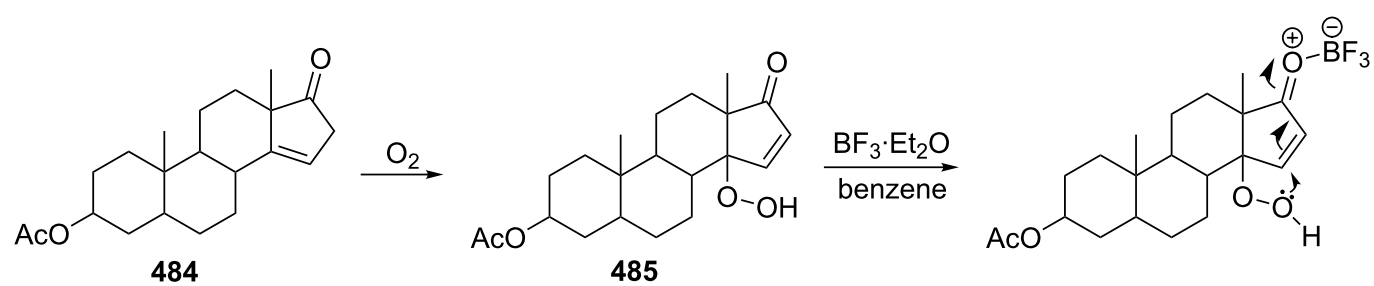

485<smiles>CC(=O)OC1CCC2(C)C(CCC3C(=O)C(C)(C(=O)C=CO)CCC32)C1</smiles>

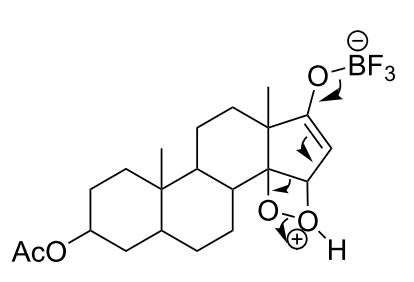

486

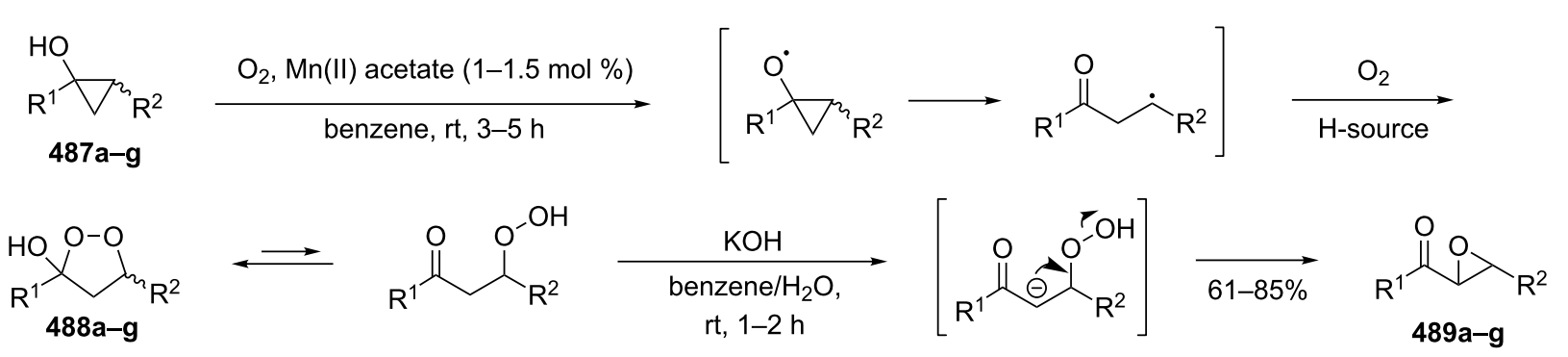

a: $\mathrm{R}^{1}=\mathrm{Me}, \mathrm{R}^{2}=n-\mathrm{C}_{6} \mathrm{H}_{13} ; \mathbf{b}: \mathrm{R}^{1}=\mathrm{Me}, \mathrm{R}^{2}=\mathrm{Ph} ; \mathbf{c}: \mathrm{R}^{1}=\mathrm{Et}, \mathrm{R}^{2}=\mathrm{Ph}$;

d: $\mathrm{R}^{1}=\mathrm{R}^{2}=\mathrm{Et} ; \mathbf{e}: \mathrm{R}^{1}=\mathrm{Pr}, \mathrm{R}^{2}=\mathrm{Me} ; \mathbf{f}: \mathrm{R}^{1}=n-\mathrm{C}_{6} \mathrm{H}_{13}, \mathrm{R}^{2}=\mathrm{Me}$;

g: $\mathrm{R}^{1}=n-\mathrm{C}_{7} \mathrm{H}_{15}, \mathrm{R}^{2}=\mathrm{H}$

Scheme 140: The base-catalyzed rearrangement of cyclic peroxides $488 a-g$.<smiles>[R]C=CC([R])=O</smiles>

490 cat. $2 \mathrm{Cl}_{3} \mathrm{CCO}_{2} \mathrm{H}(10 \mathrm{~mol} \%)$

$$
\mathrm{H}_{2} \mathrm{O}_{2} \text { (1.5 equiv) }
$$

dioxane, $30^{\circ} \mathrm{C}, 20 \mathrm{~h}$<smiles>[R][C]1CC([R])(O)OO1</smiles>

491

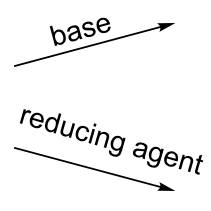

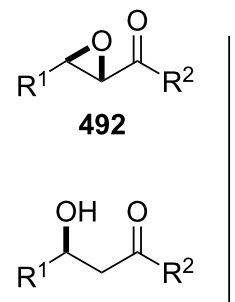

493<smiles>C=CCN1CC2CCC1CN2C(N)c1ccnc2ccc(OC)cc12</smiles>

cat.

Scheme 141: Synthesis of chiral epoxides and aldols from peroxy hemiketals 491 .

nied by emission of light. This process is of special interest for the application in clinical and biological analytical methods, and the synthesis of carbonyl-containing compounds 498 (Table 23) [462-475].

Catalytic amounts of a sodium bicarbonate are sufficient to induce the decomposition of anthracene endoperoxide 499 to anthraquinone (500) (Scheme 143) [478].
An intramolecular rearrangement of $\alpha$-azidoperoxides $\mathbf{5 0 2}$ promoted by DBU provides esters 503. The reaction takes place with alkyl, aryl and heteroaryl $\alpha$-azidoperoxides generated from the corresponding aldehydes 501 (Scheme 144) [479].

There could be two possible paths for base-promoted decomposition of $\alpha$-azidoperoxides $\mathbf{5 0 2}$ (Scheme 145). The abstraction of the $\alpha$-hydrogen in the azidoperoxide leads to the direct de- 


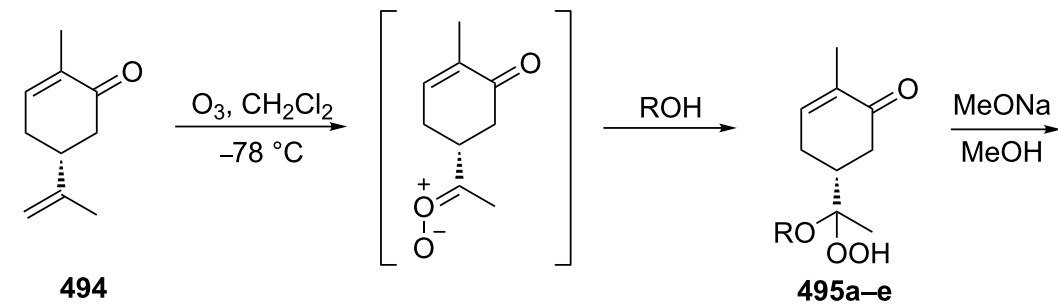

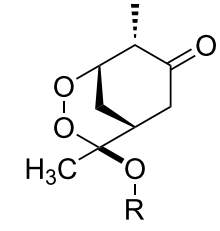

496a: $R=M e, 38 \%$

496b: $R=E t, 32 \%$

496c: $R=B u, 35 \%$

496d: $R=$ Pent, $28 \%$

496e: $R=$ Oct, $24 \%$

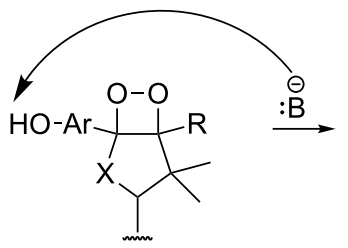

497

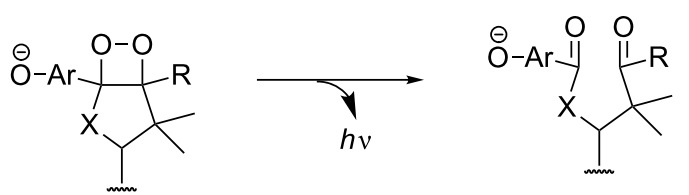

498

$\mathrm{X}=\mathrm{O} ; \mathrm{N}-\mathrm{R}^{1} ; \mathrm{S}(\mathrm{O})_{n} n=0,1,2$

Entry
6


Table 23: Base-catalyzed intramolecular rearrangement of 1,2-dioxetanes. (continued)

$\mathrm{S}, \mathrm{SO}$,
$\mathrm{S}(\mathrm{O})_{2}$

$$
\mathrm{R}=\mathrm{H}, \mathrm{Me}, \mathrm{Ph}
$$

10<smiles>Oc1ccc2c(c1)C1(OO2)OC2CC3CC(C2)C1C3</smiles>

TBAF in DMSO at $25^{\circ} \mathrm{C}$<smiles>CO[13CH2]c1ccc(C(OC)(OO)C23CCC(CC2)CC3)cc1</smiles>

TBAF in THF/DMSO (1:1) at $25^{\circ} \mathrm{C}$<smiles>CCOC(=O)NC1(c2cc(F)ccc2O)C(=O)OC1=O</smiles>

13

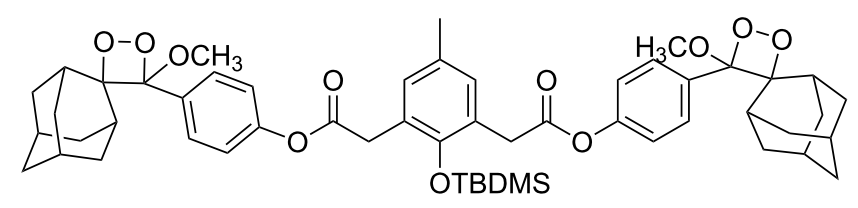

TBAF in DMSO/PBS buffer

composition of the peroxide bond, which provides acylazide $\mathbf{5 0 4}$ and alkoxide ion $\mathbf{5 0 5}$ (path A). Further, the exchange of the azide moiety in the acylazide with an alkoxide ion generates esters 503. On the other hand, an abstraction of the $\alpha$-hydrogen in the azidoperoxide leads to a resonance-stabilized intermediate I (path B). Then, an intramolecular 1,2-alkoxy migration of 499 I, via scission of the peroxide bond, followed by cleavage of the C-N bond (intermediate IV) affords the desired ester 503. On basis of control experiments, the reaction is probably following the latter path.

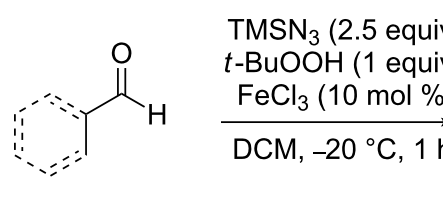

501<smiles>CC(C)(C)OOC(N)c1ccccc1</smiles>

502 $\underset{\text { EtOAc, } 0^{\circ} \mathrm{C}, 15 \mathrm{~min}}{\stackrel{\mathrm{DBU}}{1} \text { equiv })}$<smiles>CC(C)(C)OC(=O)c1ccccc1</smiles>

$503,42-92 \%$ 


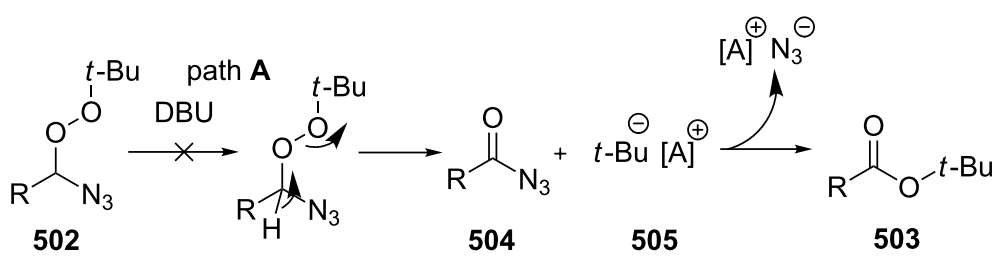

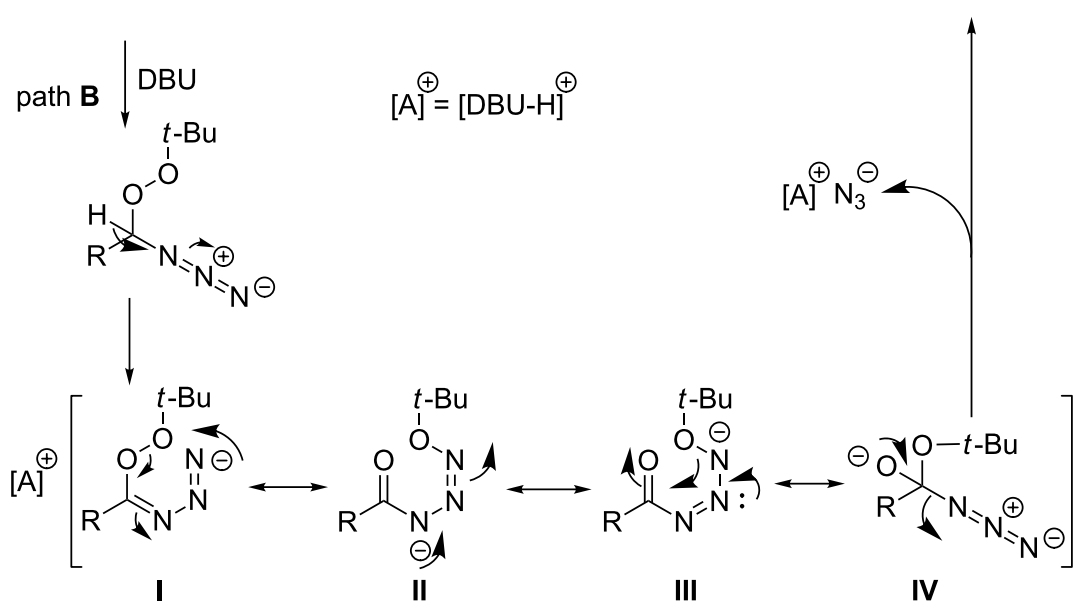

Scheme 145: Two possible paths for the base-promoted decomposition of $\alpha$-azidoperoxides $\mathbf{5 0 2 .}$

2.4 Thermal and photochemical transformations of organic peroxides

Story and co-workers discovered that the thermal and photochemical decomposition of cyclic ketone peroxides 506 produces cycloalkanes $\mathbf{5 0 7}$ and cyclic lactones $\mathbf{5 0 8}$ (Scheme 146 and Scheme 147) [480-483]. This transformation is a general method for the synthesis of macrocyclic compounds from readily available starting materials.
Examples of the thermal decomposition and photolysis of diperoxide 506a and triperoxide 506 b are given in Table 24.

Unsaturated endoperoxides are convenient starting compounds for thermal and photochemical rearrangements. The thermal rearrangement of endoperoxides $\mathbf{A}$ into diepoxides $\mathbf{B}$ (Scheme 148) is one of the commonly used transformations $[353,484,485]$.

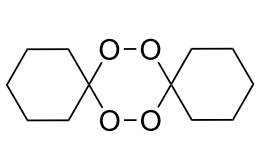

$506 a$
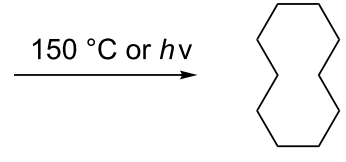

$507 a$<smiles>O=C1CCCCC1</smiles>

$508 \mathrm{a}$

45b<smiles>C1CCC2(CC1)OOC1(CCCCC1)OOC1(CCCCC1)OO2</smiles>

506b

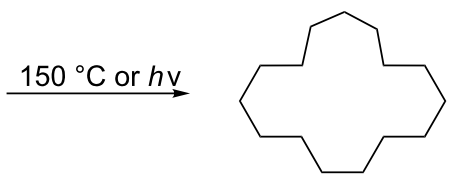

$507 b$<smiles>O=C1CCCCCCCCCCCCCCO1</smiles>

508b<smiles>O=C1CCCCC1</smiles>

45b 


\begin{tabular}{|c|c|c|c|c|}
\hline \multirow[t]{2}{*}{ Peroxide } & \multirow[t]{2}{*}{ Conditions } & \multicolumn{3}{|c|}{ Yields, \% } \\
\hline & & $\begin{array}{l}\text { Cycloalkane } \\
(\mathbf{5 0 7})\end{array}$ & $\begin{array}{l}\text { Macrolactone } \\
(\mathbf{5 0 8})\end{array}$ & $\begin{array}{l}\text { Ketone } \\
(\mathbf{4 5 b})\end{array}$ \\
\hline \multirow[t]{2}{*}{$506 a$} & $150{ }^{\circ} \mathrm{C}, 30 \mathrm{~min}$ & 44 & 23 & 21 \\
\hline & $h v, \mathrm{MeOH}, 3 \mathrm{~h}$ & 14 & 10 & 20 \\
\hline \multirow[t]{2}{*}{$506 b$} & $150{ }^{\circ} \mathrm{C}, 30 \mathrm{~min}$ & 16 & $<1$ & 15 \\
\hline & $h \mathrm{v}, \mathrm{MeOH}, 3 \mathrm{~h}$ & 15 & 25 & 20 \\
\hline
\end{tabular}

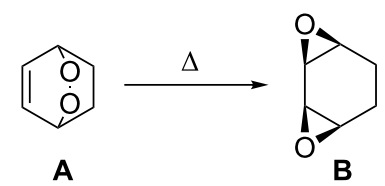

Scheme 148: The thermal rearrangement of endoperoxides $A$ into diepoxides $\mathbf{B}$.

The transformation of peroxide $\mathbf{5 1 0}$ is a key step in the synthesis of the cytotoxic agent stemolide (511) from methyl dehydroabietate (509) (Scheme 149) [486].

It was shown that thermal and photochemical transformations of

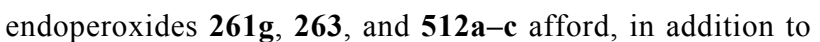
diepoxides 513a-e, keto epoxides 514a-e [487-489]. Examples of the thermal decomposition and photolysis of endoperoxides $\mathbf{2 6 1 g}, \mathbf{2 6 3}$, and 512a-c are given in Table 25.
The possible mechanism of the rearrangement of endoperoxide $\mathbf{2 6 1 \mathrm { g }}$ is shown in Scheme 150. It is supposed that diepoxide 513a and keto epoxide 514a are generated from diradical 516 via cyclization of the diradical or a 1,2-hydride shift, respectively. Since 1,4-cyclohexanedione is not generated from endoperoxide, it can be concluded that the first cyclization of $\mathbf{5 1 5}$ to 1,3-biradical $\mathbf{5 1 6}$ occurs rapidly and the formation of epoxide rings takes place successively rather than simultaneously.

The photooxidation of indene $\mathbf{5 1 7}$ without a sensitizer provides dioxetane 518, in the presence of Rose Bengal, the diepoxyendoperoxide $\mathbf{5 2 1}$ is obtained. Product $\mathbf{5 2 1}$ originates probably from a $[2+4]$ addition of singlet oxygen to give $\mathbf{5 1 9}$, followed by rearrangement to diepoxydiene $\mathbf{5 2 0}$, which is capable of adding a second mole of oxygen. The use of meso-tetraphenylporphyrin instead of Rose Bengal leads to the formation of diendiperoxide 522 (Scheme 151) [484].<smiles>COC(=O)[C@]1(C)CCC[C@]2(C)c3ccc(C(C)C)cc3CC[C@H]21</smiles>

509

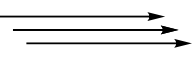<smiles>CC1(C)C2CCC3=C(COC3=O)C2CCC12CCOC2</smiles>

510

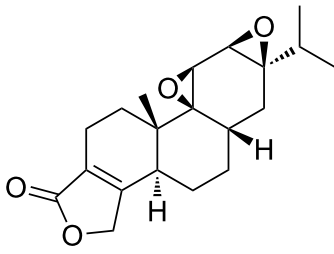

stemolide (511)

Scheme 149: The transformation of peroxide 510 in the synthesis of stemolide (511).<smiles>C1CC2CCC1O2</smiles>

$261 \mathrm{~g}$<smiles>[O-]C12CCC(CC1)O2</smiles>

515<smiles>[O]C1CCCC1O</smiles>

516<smiles>C1CC2OC1C1OC21</smiles>

$513 a$

$\stackrel{H \text { shift }}{ }$<smiles>O=C1CCC2OC12</smiles>

$514 a$ 


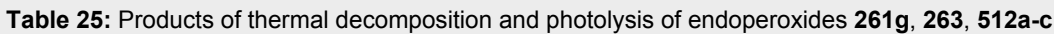

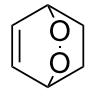

261g<smiles>C1=CC2COC1CCO2</smiles>

263<smiles>C1=CC2CCCCC1OO2</smiles>

$512 a$

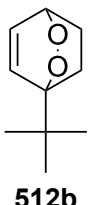

512b<smiles>CC1=CC2OCC1O[C@H]2C(C)C</smiles>

512c

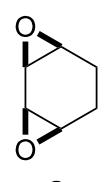

a

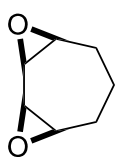

b
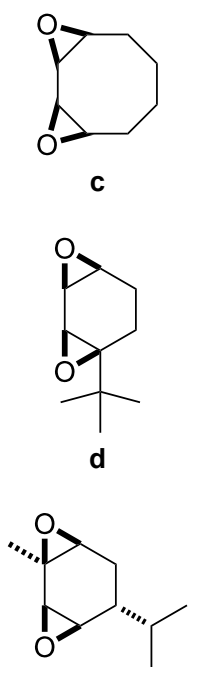

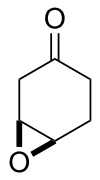

a

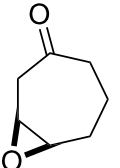

b
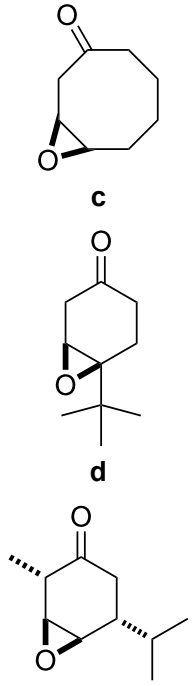

$\triangle 36: 65$

hv $28: 72$

$\triangle 90: 10$

hv 33:67

$\Delta-$ $h v 35: 65$

$\triangle 65: 35$ hv 53:37

$\triangle 58: 42$ hv $24: 76$<smiles>c1ccc(C23Cc4ccccc4C2(c2ccccc2)OO3)cc1</smiles>

518<smiles>c1ccc(C2=C(c3ccccc3)c3ccccc3C2)cc1</smiles>

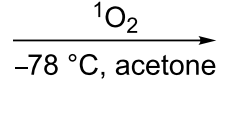<smiles>C1=CC2=C(c3ccccc3)C3(c4ccccc4)CC2(C=C1)OO3</smiles>

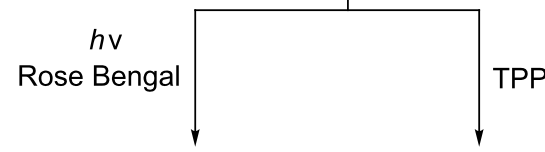

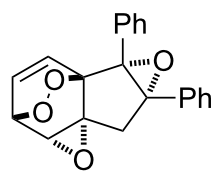

521

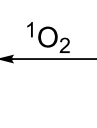<smiles>C1=CC2OC23CC2(c4ccccc4)OC2(c2ccccc2)C3=C1</smiles>

520

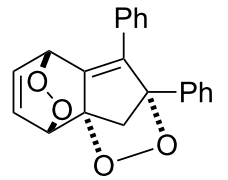

522 
Ascaridole (523) was slowly isomerized into isoascaridole (524) under irradiation with visible light (Scheme 152) [490]. Thermal and photochemical isomerization of related endoperoxides have been applied to the syntheses of other ascaridole analogs [491].

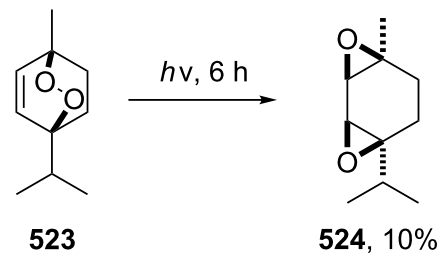

Scheme 152: The isomerization of ascaridole (523).

The diepoxide $\mathbf{5 2 6}$ was obtained in $67 \%$ yield by photolysis of 525 with a medium-pressure $\mathrm{Hg}$ vapor lamp (Scheme 153) [492].

The thermal transformation of endoperoxides produces mainly bis-epoxides, but can also provide unexpected products such as epoxy ketals. The heating of endoperoxide 236 to $160{ }^{\circ} \mathrm{C}$ in tol- uene affords epoxy ketal $\mathbf{5 2 8}$ in 53\% yield through the formation of biradical 527 (Scheme 154) [347].

The photooxidation of cyclopentadiene (529) in an alcohol solution in the presence of polymerization inhibitors at a temperature higher than $0{ }^{\circ} \mathrm{C}$ gave cis-4,5-epoxy-2-pentenal (531) in $58 \%$ yield, cis-1,2,3,4-diepoxycyclopentane (532) as a byproduct (in 7\% yield), and polymers instead of the expected peroxide 530 (Scheme 155) [344].

The extensive development of methods for the synthesis of cyclopentenones lies in the fact that this structural unit is present in some natural compounds, such as dihydrojasmone, prostaglandins, and rethrolones. The mechanism of thermal decomposition of saturated fulvene endoperoxides 533a-d involves the formation of one of the three intermediates $\mathbf{A}, \mathbf{B}$, C, which are precursors to cyclopentenones 534a-d (Table 26) [493].

The replacement of the vinyl group at the exocyclic double bond in the fulvene precursor by a 3-butenyl group and the thermal decomposition of the resulting endoperoxides $\mathbf{5 3 5}$ at $80{ }^{\circ} \mathrm{C}$ lead to a [3,4]-sigmatropic shift of the 3-butenyl group and for-

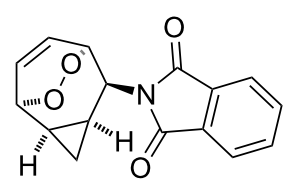

525
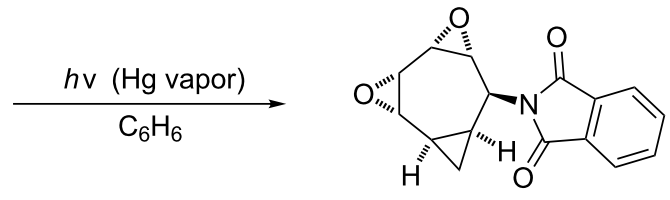

526

Scheme 153: The isomerization of peroxide 525.

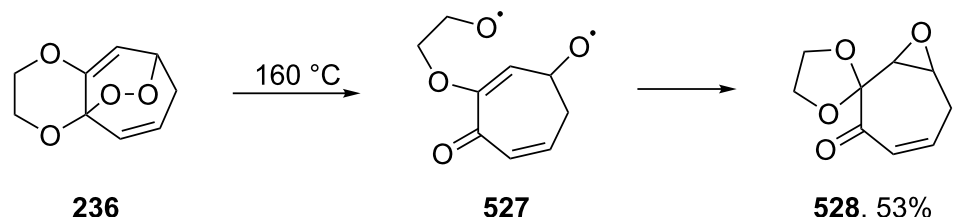

Scheme 154: The thermal transformation of endoperoxide 355.

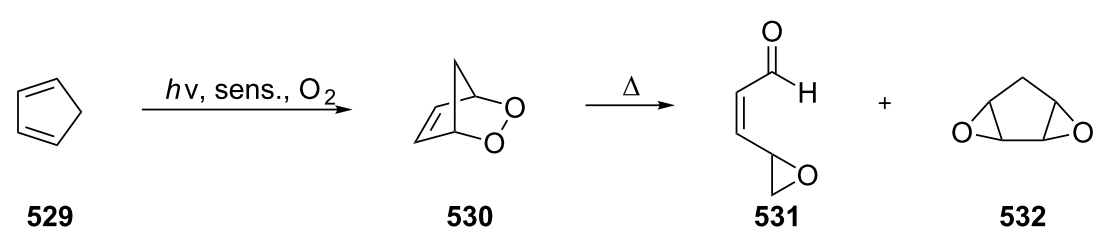

Scheme 155: The photooxidation of cyclopentadiene (529) at a temperature higher than $0{ }^{\circ} \mathrm{C}$ 
Table 26: Synthesis of cyclopentenones $534 a-d$ from saturated fulvene endoperoxides $533 a-d$<smiles>[R]C=CC([R1])=C1C2COC1C2C</smiles>

533

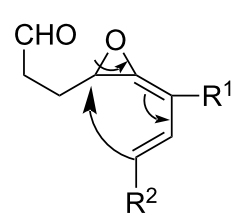

A<smiles>[R]C1=CC2([R])C(=O)C13CCCCC23C</smiles>

B
$\mathrm{OHC}$

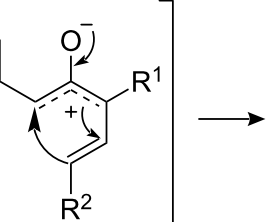

C

Yield (trans:cis)

mation of the 5-oxo-6-heptenal derivatives 536. The mechanism of this process involves the formation of epoxide $\mathbf{A}$, which undergoes a [3,4]-shift through the intermediate $\mathbf{B}$ [494] (Table 27).

The thermal rearrangement of endoperoxides 538a,b, which are generated by the photooxidation of furanosyl furans $537 \mathbf{a}, \mathbf{b}$, selectively affords glycosides 539a,b (Scheme 156) [495].
The methylene blue-sensitized photooxidation of arabinofuranosyl furan 537a as an 1:6 $\alpha, \beta$-anomeric mixture at $-20{ }^{\circ} \mathrm{C}$ followed by warming of the reaction mixture to room temperature produced furanoside 539a as an anomeric mixture in the same molar ratio. The photooxidation of pure $\beta$-arabinofuranosyl furan 537a produced exclusively $\beta$-furanoside 539a. Based on these data, the intermediate endoperoxide 538a originates from the cycloaddition of ${ }^{1} \mathrm{O}_{2}$ to the furanosyl furan. The selective<smiles>[R]c1ccc([C@@H]2O[C@H](COCc3ccccc3)[C@@H](OCc3ccccc3)[C@H]2O)o1</smiles>

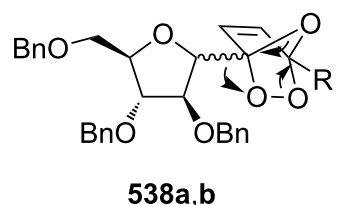

$538 a, b$

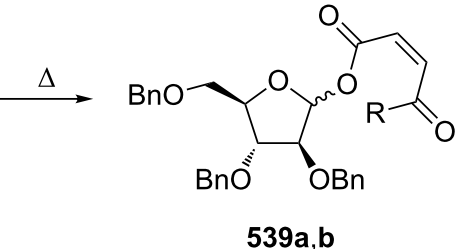

$539 a, b$

a: $R=H$
b: $R=M e$ 
Table 27: The mechanism and results of the thermal rearrangement of saturated fulvene endoperoxides $\mathbf{5 3 5 a - d . ~}$

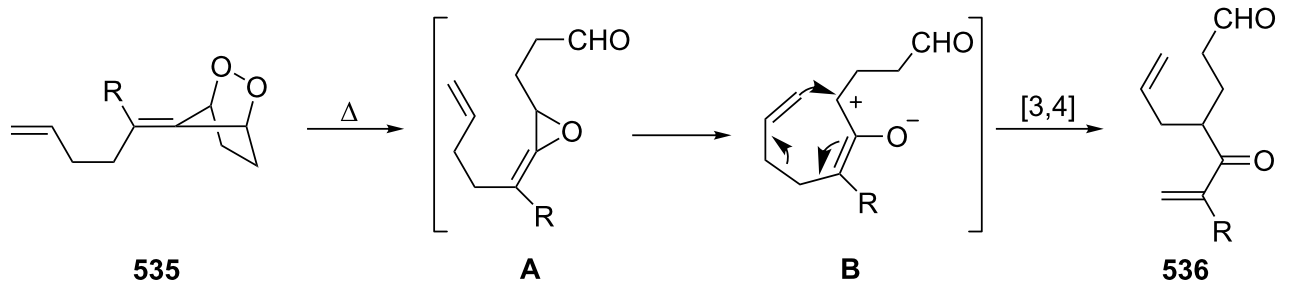

535

A

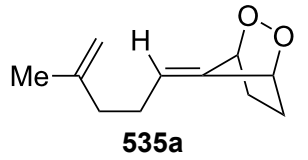

535a<smiles>C=CCC1CCCC1=C1C2CCC1OO2</smiles>

535b<smiles>C=C(C)CC1CCCC1=C1C2CCC1OO2</smiles>

535c<smiles>C=C(C)CC1CCCCCC1=C1C2CCC1OO2</smiles>

535d
Product<smiles></smiles>

thermal rearrangement of endoperoxide 538a, which is similar to the Baeyer-Villiger rearrangement with the retention of the configuration, results in the corresponding O-derivatives.

The thermally unstable endoperoxides 541a-d generated from 2-alkoxyfurans 540a-d rearrange through several pathways depending upon the nature of the substituent at the carbon atom C5 in $\mathbf{5 4 1}$ with formation of $\mathbf{5 4 2}$ or $\mathbf{5 4 3}$ (Table 28) [496].

The rearrangement of endoperoxides $\mathbf{5 4 1} \mathbf{a}-\mathbf{c}$ containing a substituent with a tertiary hydroxy group in the 5 position results in the formation of hydroperoxyoxetanes $\mathbf{5 4 2 a - c}$ and trace amounts of Z-ketoesters 543a-c. Under the same conditions, the rearrangement of endoperoxide $\mathbf{5 4 1 d}$ containing a substituent with a secondary hydroxy group in the 5 position produces exclusively the Z-keto ester 543d [497].

This difference is apparently attributable to the following two factors: (1) the lower nucleophilicity of the secondary hydroxy group compared to the tertiary hydroxy group; (2) the conformer, which would be suitably orientated towards the nucleophilic attack, is sterically unfavored in the case of $\mathrm{R}^{2}=\mathrm{H}$. At $-20{ }^{\circ} \mathrm{C}$, the transformation of $\mathbf{5 4 1 d}$ into a conformational isomer occurs more slowly than the thermal decomposition giving 543d (Scheme 157). Thermal rearrangements of strained cyclic peroxides 544a-d and 546a-e provide a versatile tool for the synthesis of carbonyl compounds 545a-d and 547a-e and heterocyclic systems 548 and 549 (Scheme 158) [498,499]. 
Table 28: Results of the rearrangement of endoperoxides 541a-d.<smiles>[R]C([R])(O)c1cc(OC)oc1[Al]</smiles>

$540 a-d$

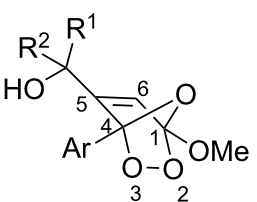

$541 \mathrm{a}-\mathrm{d}$<smiles>[R]C1([R])OC(O)([Al])C1=CC(C)=O</smiles>

542a-d<smiles>[R]C([R])(O)C(=CC(=O)[AlH2])C(=O)OC</smiles>

$543 a-d$

\begin{tabular}{|c|c|c|c|c|c|}
\hline Compound & $\mathrm{R}^{1}$ & $\mathrm{R}^{2}$ & $\mathrm{Ar}$ & Yield of $542, \%$ & Yield of $543, \%$ \\
\hline $\mathbf{a}$ & Et & Et & $\mathrm{Ph}$ & 88 & traces \\
\hline b & Et & Et & $4-\mathrm{Br}-\mathrm{C}_{6} \mathrm{H}_{4}$ & 92 & traces \\
\hline c & $\mathrm{Ph}$ & $\mathrm{Ph}$ & $4-\mathrm{Br}-\mathrm{C}_{6} \mathrm{H}_{4}$ & 93 & traces \\
\hline d & $\mathrm{Me}$ & $\mathrm{H}$ & $\mathrm{Ph}$ & 0 & 87 \\
\hline
\end{tabular}

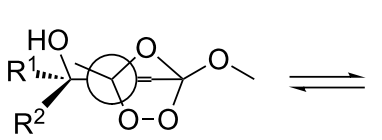

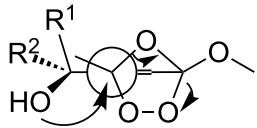

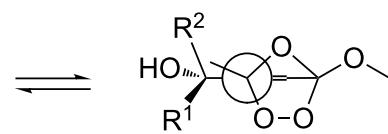

541

542

Scheme 157: The transformation of peroxides 541<smiles>[R]C(=O)N1CC(C)(C)C(O)(C(C)(C)C)C1(O)c1cccc([O-])c1</smiles>

$544 a-d$<smiles>[X]c1ccccc1C12OCC(C)(C)C1(C(C)(C)C)OO2</smiles>

$546 a-e$<smiles>[R]C(=O)N(CC(C)(C)C(=O)C(C)(C)C)C(=O)c1cccc(Oc2ccccc2)c1</smiles>

$545 a-d$ a: $\mathrm{Y}=\mathrm{Me}, \mathrm{R}=t-\mathrm{BuO}$

b: $Y=H, R=t-B u O$

c: $Y=M e, R=P h$

d: $Y=H, R=P h$

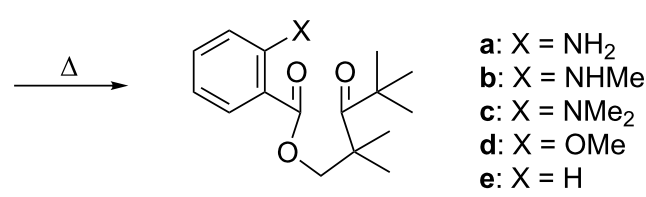

$547 a-e$

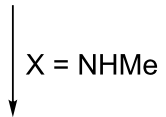

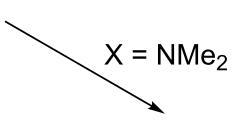

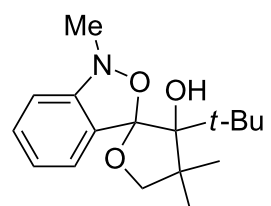

548

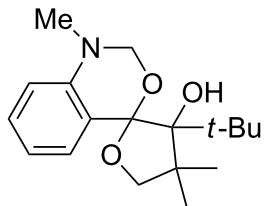

549

Scheme 158: The thermal rearrangements of strained cyclic peroxides. 
The thermal rearrangement of diacyl peroxide 551 was carried out in the synthesis of the C4-epi-lomaiviticin B core $\mathbf{5 5 3}$. Diacyl peroxide $\mathbf{5 5 1}$ was prepared from $p$-nitroperbenzoic acid ( $p$-NPBA) and the acid chloride of carboxylic acid 550. An ionic Criegee-like rearrangement of peroxide 551 upon heating resulted in the corresponding acyl carbonate species. The reaction of $\mathrm{MeOH}$ with this acyl carbonate intermediate provided a single diastereomer of secondary carbinol $\mathbf{5 5 2}$ in 38\% yield (Scheme 159) [500].

Two diastereoisomeric dioxindolylalanines $\mathbf{5 5 6}$ were identified after the ${ }^{1} \mathrm{O}_{2}$ oxidation of tryptophan (554). Mechanistic investigations supported the dioxindolylalanine formation through a dioxetane intermediate 555 (Scheme 160) [501].

\subsection{Metal-catalyzed transformations of peroxides}

This section focuses on transformations of peroxides under the action of the most representative metals used for these types of reactions: $\mathrm{Fe}(\mathrm{II}), \mathrm{Co}(\mathrm{II}), \mathrm{Ru}(\mathrm{II})$, and $\mathrm{Pd}(\mathrm{II})$.
The Fe(II)-promoted activation of peroxides is believed to be involved in the antimalarial activity of a number of peroxides, including the natural product artemisinin. The understanding of the underlying mechanism of the Fe(II)-promoted cleavage of bicyclic peroxides is critical to the design and preparation of more efficient antimalarial peroxides. From this perspective, metal-catalyzed transformations of peroxides are of special interest. It was shown [502] that the reaction of fluorinated cyclic peroxide 557a with $\mathrm{FeBr}_{2}$ in THF proceeds through an intermediate O-centered radical to form epoxy ketone 558a and 1,4-diol 559a. The reaction of 557b with $\mathrm{FeCl}_{2}\left(\mathrm{PPh}_{3}\right)_{2}$ in $\mathrm{CH}_{2} \mathrm{Cl}_{2}$ proceeds in a different manner through an intermediate O-centered radical to yield diepoxide 560b (Scheme 161) [503].

In a related study investigating the reaction of $\mathbf{5 5 7 a - c}$ with $\mathrm{FeBr}_{2}$, bis-epoxides 560a-c and epoxy ketones 561a-c were obtained as the major products (Table 29) [504] and the proposed mechanism of the rearrangement of $557 \mathbf{a}-\mathbf{c}$ is presented in Scheme 162.

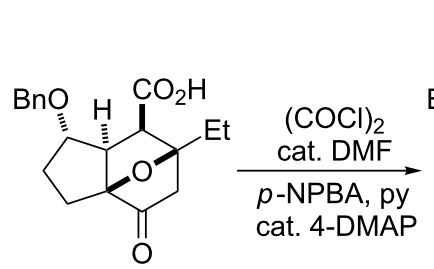

550<smiles>CCC12CC(=O)C3(CCC(OCc4ccccc4)[C@H]13)C2C(=O)OOC(=O)c1ccc([N+](=O)[O-])cc1</smiles>

551
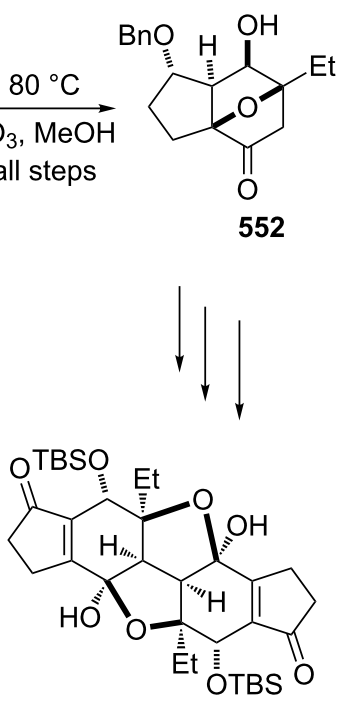

C4-epi-lomaiviticin B core

Scheme 159: The thermal rearrangement of diacyl peroxide 551 in the synthesis of C4-epi-lomaiviticin B core 553.<smiles>N[C@@H](Cc1c[nH]c2ccccc12)C(=O)O</smiles>

554

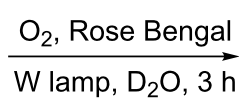<smiles>Cc1cc2c(cc1C)C1(C[C@H](N)C(=O)O1)OC2N</smiles>

555<smiles>N[C@@H](CC(O)(C(=O)O)C(=O)O)C(=O)Nc1ccccc1</smiles>

556

Scheme 160: The ${ }^{1} \mathrm{O}_{2}$ oxidation of tryptophan (554) and rearrangement of dioxetane intermediate 555 


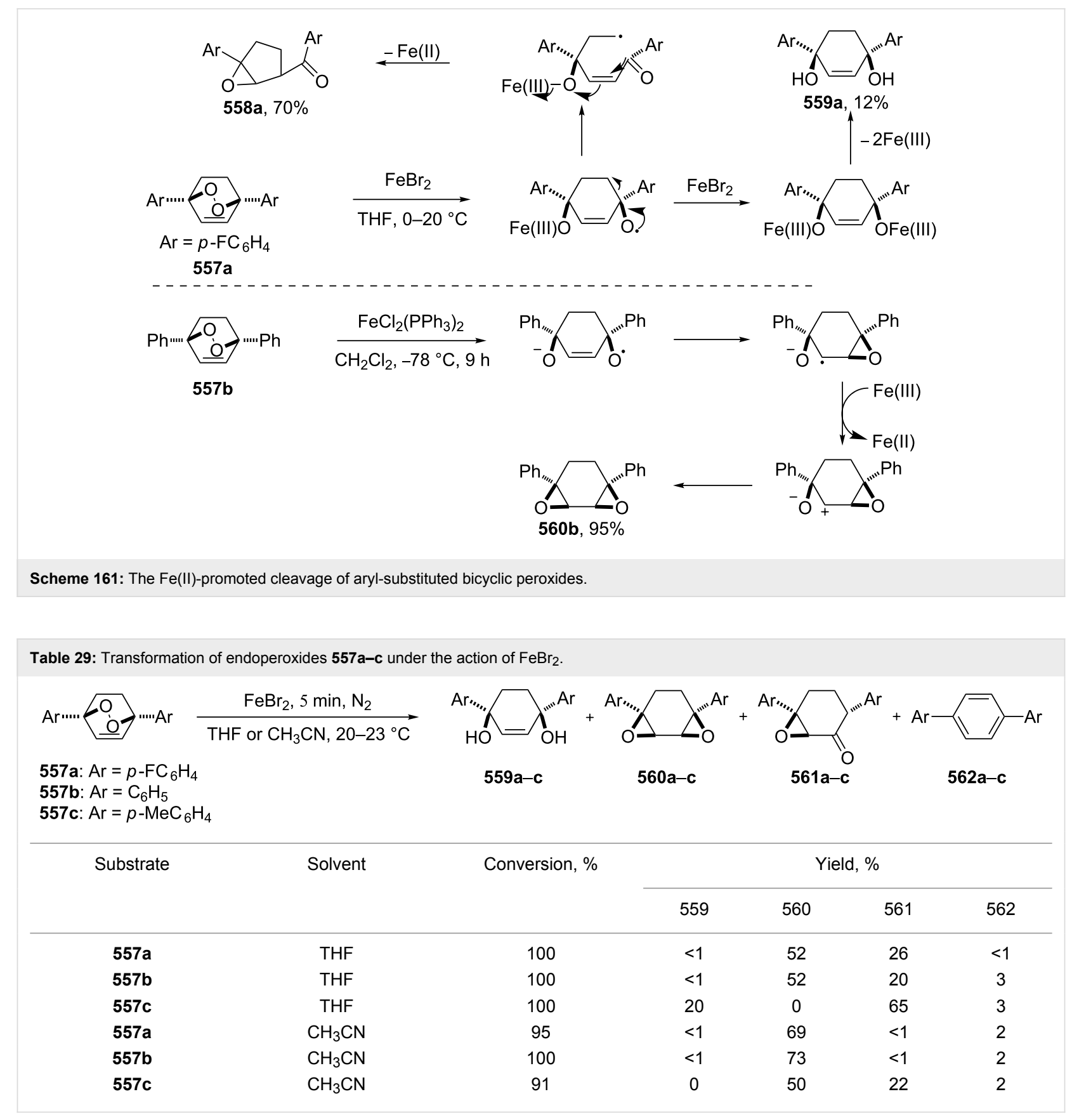

Both in THF and $\mathrm{CH}_{3} \mathrm{CN}$, the intermediate O-centered radical

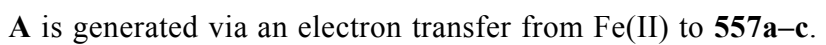
The transformation of intermediate $\mathbf{A}$ can proceed through two different pathways. The first involves the intramolecular addition of an O-centered radical to the double bond in radical $\mathbf{A}$ to form C-centered radical B (path $\mathbf{A}$ ). The second pathway involves an electron transfer from $\mathrm{Fe}$ (II) to radical $\mathbf{A}$ to give intermediate $\mathbf{G}$ (minor path B). The intramolecular electron transfer in intermediate $\mathbf{B}$ results in the formation of carbocation $\mathbf{C}$ followed by the formation of diepoxide $\mathbf{5 6 0 a}-\mathbf{c}$ and concomitant elimination of $\mathrm{Fe}(\mathrm{II})$. The generation of epoxy ketone 561a-c from 560a-c can occur through paths $\mathbf{C}$ and $\mathbf{D}$. Paths $\mathbf{E}$ and $\mathbf{F}$ apparently give rise to 1,4-diol 559a-c and diarylbenzene 562a-c, respectively, from intermediate $\mathbf{G}$.

The reaction of dioxolane $\mathbf{5 6 3}$ with Fe(II) sulfate produces an $\mathrm{O}$-centered radical, and the $\beta$-scission of the latter gives a $\mathrm{C}$-centered radical, the oxidation and further cyclization of which yields 564 (Scheme 163) [505].

The monocyclic 1,2-dioxane $\mathbf{5 6 5}$, as opposed to related dioxolane 563, decomposes under the action of $\mathrm{Fe}(\mathrm{II})$ with exclusive 


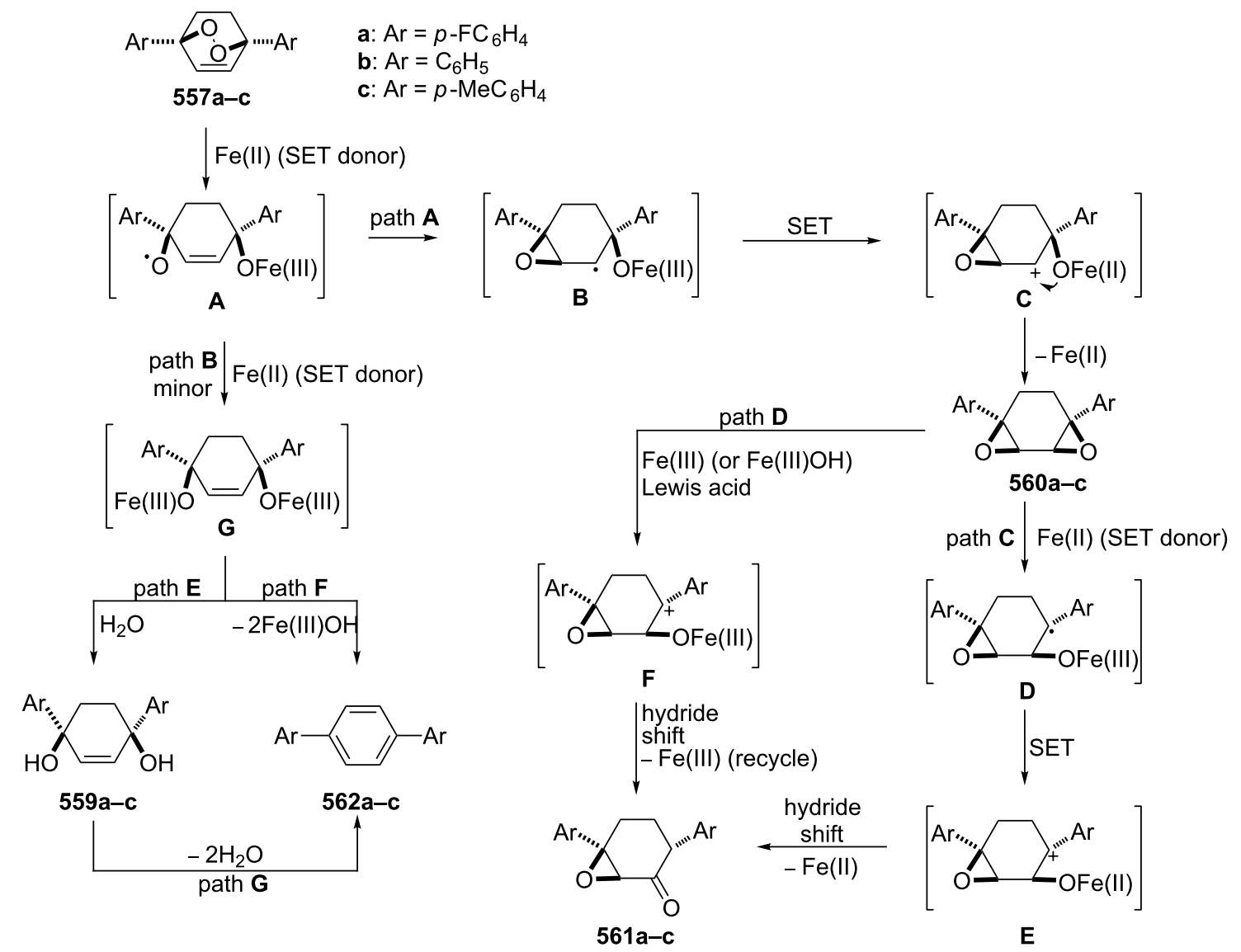

Scheme 162: The proposed mechanism of the Fe(II)-promoted rearrangement of $557 a-c$

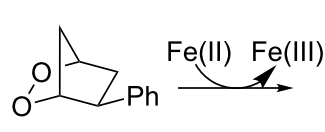

563<smiles>O=CCC(O)CC(O)c1ccccc1</smiles>

$\bigvee_{\mathrm{Fe}(\mathrm{II})}$<smiles>CC(C)(C)[R]1[C@@H](O)C[C@@H](O)C[C@@H]1CO</smiles>

Scheme 163: The reaction of dioxolane 563 with $\mathrm{Fe}(\mathrm{II})$ sulfate.

formation of a 1:1 mixture of products $\mathbf{5 6 6}$ and $\mathbf{5 6 7}$. This is attributed to the fact that the reaction proceeds through 1,5-hydrogen transfer, while $\beta$-scission does not occur (Scheme 164) [505].

The reaction of $\mathrm{Fe}(\mathrm{II})$ cysteinate with dioxolane $\mathbf{5 6 8}$ produced compounds 569 and 570, which were isolated from the reaction mixture. The formation of methyl acetate $\mathbf{5 7 1}$ was confirmed by $\mathrm{GC}$ analysis of the reaction mixture before work-up (Scheme 165) [506].

The reaction of 1,2-dioxanes $\mathbf{5 7 2 a}-\mathbf{c}$ with $\mathrm{FeCl}_{2}$ is accompanied by the formation of lactones $\mathbf{5 7 3 a}, \mathbf{b}$, which were isolated in the individual state (Scheme 166) [507].

The reaction of synthetic tetraoxane $\mathbf{5 7 4}$ with Fe(II) cysteinate affords a complex mixture of products. Only one product, $\mathbf{5 7 5}$, could be isolated from the mixture and identified. This was the first work, where the Fe(II)-promoted cleavage of 1,2,4,5tetraoxane was investigated (Scheme 167) [508].

The hypothesis that this difference in the structure of the reaction products is associated with the rearrangement of intermediate endoperoxides gave impetus to research on the reaction of endoperoxides with transition metal derivatives. It was found that the catalytic rearrangement of endoperoxides using cobalt meso-tetraphenylporphyrin occurs in high yield. Therefore, this is an efficient approach to the synthesis of syn-1,2:3,4-diepoxides from 1,3-dienes under mild conditions. Table 30 summa- 


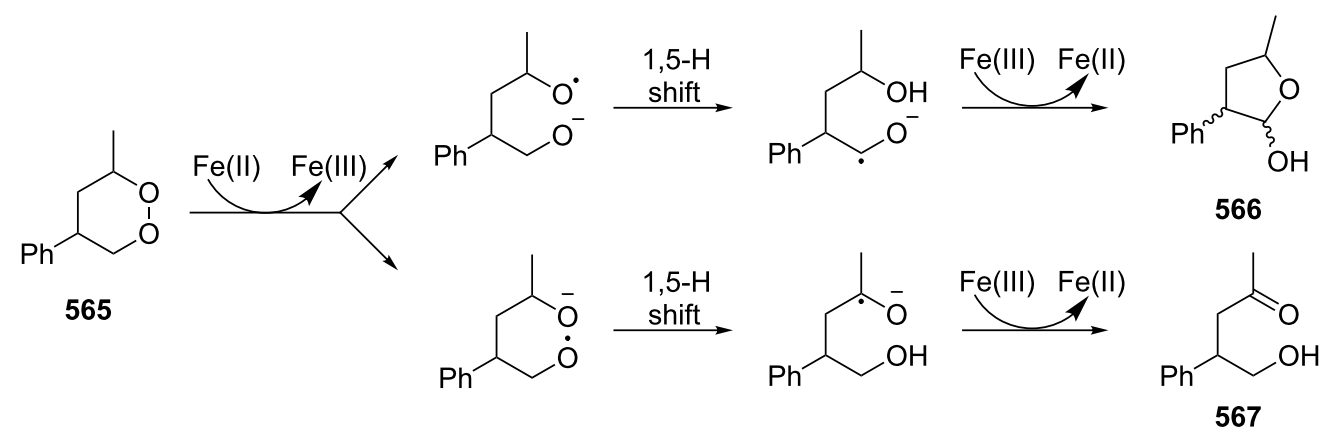

Scheme 164: Fe(II)-promoted rearrangement of 1,2-dioxane 565.

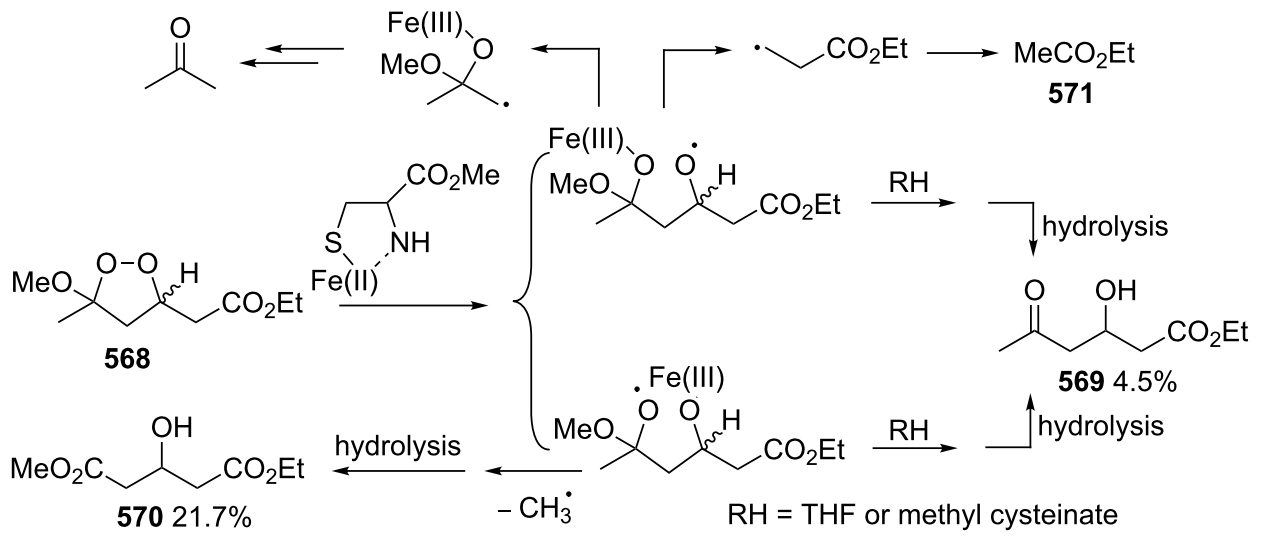

Scheme 165: Fe(II) cysteinate-promoted rearrangement of 1,2-dioxolane 568.<smiles>[R]C1(C)CC(C(=O)OC)C([R])(O)OO1</smiles>
$\underset{\mathrm{CH}_{3} \mathrm{CN} / \mathrm{H}_{2} \mathrm{O} 4: 1}{\stackrel{\mathrm{FeCl}_{2} \text { (5 equiv) }}{\longrightarrow}}$

572a: $R=M e R^{\prime}=\beta-E t$ 572b: $R=M e R^{\prime}=\alpha-B u$ 572c: $R=B u R^{\prime}=\beta-B u$

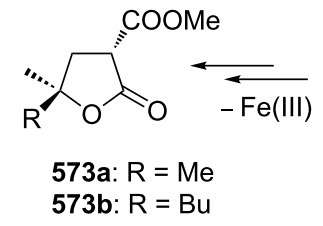<smiles>[R]O[C@]([R])(C)CC(C(=O)OC)C(=O)OC</smiles>

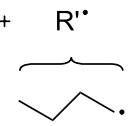

or

$>$.

Scheme 166: The transformation of 1,2-dioxanes 572a-c under the action of $\mathrm{FeCl}_{2}$.

rizes the results of the cobalt(II) tetraphenylporpyrin-catalyzed rearrangement of endoperoxides $\mathbf{5 7 6}$ [509], $\mathbf{5 7 8}$ [510], $\mathbf{5 8 0}$ [511], 582 [512], 584 [353], 586 [513], 588 [514], 590, 592 [515], 594 [516], 596 [517], and 598 [518] which afforded products structurally similar to the diepoxides prepared by thermal rearrangement of endoperoxides (Table 25). All rearrangements were stereospecific and yielded only the syn-diepoxides.

The study of the CoTPP-catalyzed transformation of bicyclic endoperoxides containing non-strained diene moieties demonstrated that the formation of epoxides can be accomplished in yields up to $90-100 \%$, while the side reaction giving epoxy ketones is suppressed. A detailed study on the CoTPP-catalyzed reaction of $600 \mathrm{a}$ showed that this reaction affords, in addition to the expected diepoxide 601a, two isomeric epoxy aldehydes 602a and 603a. The reaction of bicyclic endoperoxides 600b,c gives, instead of the expected epoxides $\mathbf{6 0 1 b}, \mathbf{c}$, exclusively epoxy aldehydes $602 \mathrm{~b}, \mathbf{6 0 3} \mathrm{b}$ and the reaction of endoperoxide 600d produces solely the diepoxide 601d (Scheme 168) [519].

The reaction of epoxy-1,2-dioxanes $604 a-d$ and 606 with Co(II) complexes affords 4-hydroxy-2,3-epoxy ketones 605a-d and 607 in good yields (Scheme 169) [364]. Possibly the selectivity towards the hydroxyketones formation is provided by means of cobalt ions interaction. The obtained compounds are useful synthons in organic synthesis. 


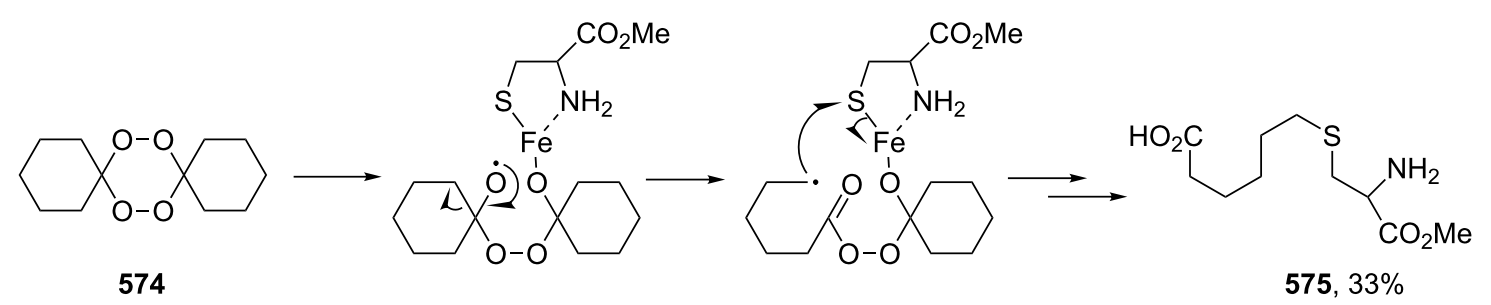

Scheme 167: Fe(II) cysteinate-promoted transformation of tetraoxane $\mathbf{5 7 4 .}$

Table 30: CoTPP-catalyzed rearrangement of endoperoxides.

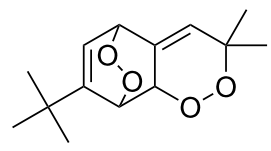

576

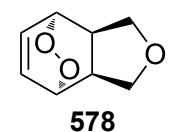<smiles>CC(=O)OCc1ccccc1COC(C)=O</smiles><smiles>c1ccc2c(c1)OC1C3COOCC3C21</smiles>

582<smiles>CC1=CC2CCC[C@H]1c1ccccc12</smiles><smiles>C1=C[C@H]2C=C[C@H](O1)C1(OCCO1)O2</smiles>

586<smiles>CC(=O)OCC1OC2C=CC1OC(C)(C)O2</smiles>

588<smiles>CC1(C)C=C2C(OO1)C1OC13C1OC13C2(C)C</smiles>

577<smiles>C1OCC2C1C1OC1C1OC21</smiles>

579<smiles>CC(=O)OCC1C(COC(C)=O)C2OC2C2OC12</smiles>

581

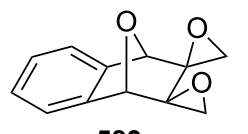

583<smiles>OC1c2ccccc2C2OC1C1(CO1)C21CO1</smiles><smiles>c1ccc2c(c1)C1OC1C1O[C@H]21</smiles>

45<smiles>C1=CC2(OCCO2)C2OC2C2OC12</smiles>

587<smiles>CC(=O)OC12OC(C)(C)OC1C1OC12</smiles>

589 
Table 30: CoTPP-catalyzed rearrangement of endoperoxides. (continued)<smiles>[R]C(=O)OC(=O)C1=NNC([R])=C2C3CCC(O3)C12</smiles>

$\mathrm{R}=\mathrm{COOCH}_{3}$

590<smiles>[R]C1=NNC([R])=C2C3C=CCC(O3)[C@H]12</smiles>

$\mathrm{R}=\mathrm{COOCH}_{3}$

592<smiles>C1=C[C@H]2O[C@H]1[C@@H]1O[C@@H]2c2ccccc21</smiles>

594<smiles>CCOC(=O)C1C=CC23OCOC2=CC(OO3)C1O</smiles>

596

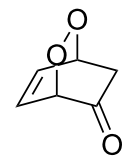

598<smiles>[R]C1=CC(C2CCCC(O)O2)C([R])=NN1</smiles>

591<smiles>[R]C1=CC([C@H]2C=CC[C@@H](O)O2)C([R])=NN1</smiles>

593<smiles>c1ccc2c(c1)[C@H]1[C@@H]3O[C@@H]3[C@@H]3O[C@H]3[C@H]21</smiles>

595<smiles>CCOC(=O)c1ccc(O)c(=O)c(O)c1</smiles>

597<smiles>O=C1C[C@H]2O[C@H]2[C@H]2O[C@H]12</smiles>

50

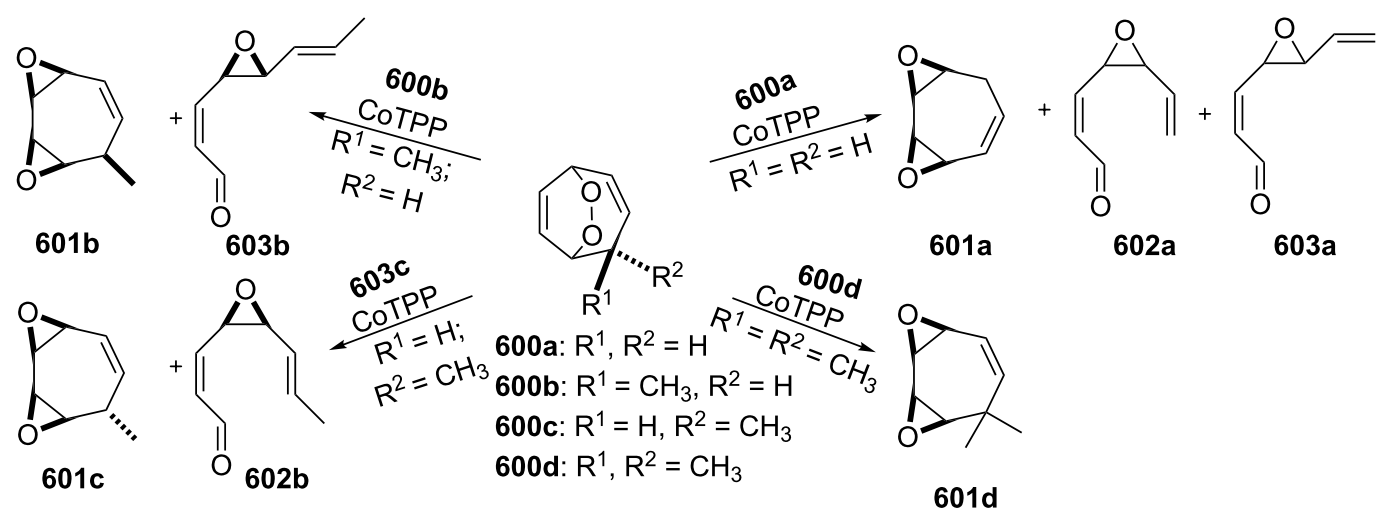

Scheme 168: The CoTPP-catalyzed transformation of bicyclic endoperoxides $600 a-d$.

The $\mathrm{Ru}(\mathrm{II})$-catalyzed reactions of 1,4-endoperoxide $\mathbf{2 6 1 \mathrm { g }}$ involves the formation of intermediate radicals $\mathbf{6 0 8 a}, \mathbf{b}$, the structures of which differ from that of the radicals generated by photolysis or thermal decomposition. Ruthenium ions have a considerable effect on the stability and reactivity of radicals, resulting in the selective transformation of peroxides under mild conditions. The reactivity also substantially depends on steric factors (Scheme 170) [503,520,521].

The Ru(II)-catalyzed transformation of 1,4-endoperoxide $\mathbf{6 0 9}$ is used as a key step in the synthesis of the natural compound, elyiapyrone A (610) (Scheme 171) [522,523]. 


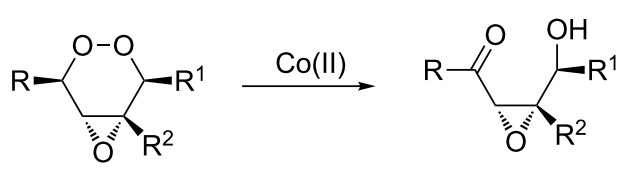

604a: $R=P h, R^{1}=P h, R^{2}=H$

604b: $\mathrm{R}=n-\mathrm{Pr}, \mathrm{R}^{1}=n-\mathrm{Pr}, \mathrm{R}^{2}=\mathrm{H}$

604c: $\mathrm{R}=\mathrm{C}_{6} \mathrm{H}_{11}, \mathrm{R}^{1}=\mathrm{C}_{6} \mathrm{H}_{11}, \mathrm{R}^{2}=\mathrm{H}$

604d: $R=i \operatorname{Pr}, R^{1}=i \operatorname{Pr}, R^{2}=H$
$605 a, 98 \%$

605b, $96 \%$

605c, $95 \%$

605d, $89 \%$<smiles>[R]C1OOC([R])C2OC12</smiles>

$\mathrm{Co}(\mathrm{II})$<smiles>[R]C(=O)C1OC1C([R])O</smiles>

606: $\mathrm{R}=\mathrm{C}_{6} \mathrm{H}_{11}, \mathrm{R}^{1}=\mathrm{C}_{6} \mathrm{H}_{11}$

Scheme 169: The CoTPP-catalyzed transformation of epoxy-1,2-dioxanes.

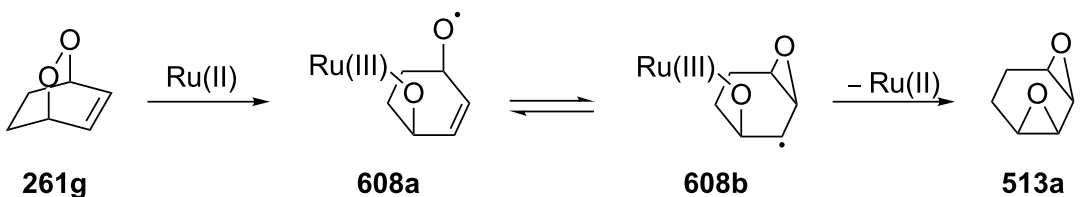

Scheme 170: The Ru(II)-catalyzed reactions of 1,4-endoperoxide $\mathbf{2 6 1 g .}$

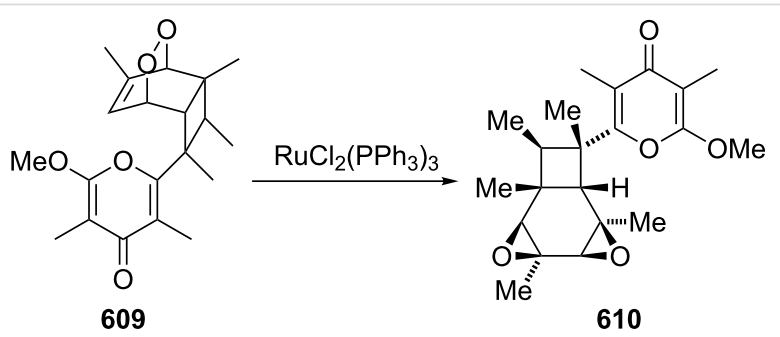

Scheme 171: The Ru(II)-catalyzed transformation as a key step in the synthesis of elyiapyrone $A(\mathbf{6 1 0})$ from 1,4-endoperoxide.

Transformations of endoperoxides catalyzed by variablevalence metals are well studied for metals such as $\mathrm{Cu}(\mathrm{II}), \mathrm{Fe}(\mathrm{II})$ or $\mathrm{Co}(\mathrm{II})$, which can initiate the reaction through a one-electron oxidation-reduction mechanism. The decomposition of endoperoxides catalyzed by $\mathrm{Ru}(\mathrm{II})$ phosphine complexes also belongs to this type of reaction and the decomposition produces diepoxides as the major products.

The reactions of endoperoxides with $\operatorname{Pd}(0)$ proceed through different pathways. Thus, bicyclic 2,3-saturated 1,4-endoperoxides $611 \mathrm{a}-\mathbf{d}$ are transformed into the corresponding 4-hydroxyketones and 1,4-diols. Bicyclic 2,3-unsaturated 1,4-endoperoxides 530, 261g, 263 produce 4-hydroxyenones, 1,4-diols, and diepoxides. Monocyclic endoperoxides 611e-g are transformed into enones, 1,4-diols, 1,4-diketones, or furan derivatives (Table 31) [524,525].

The reactivity of bicyclic substrates depends on the carbon-ring size. Strained 1,4-endoperoxide derivatives are readily decomposed under the action of $\mathrm{Pd}\left(\mathrm{PPh}_{3}\right)_{4}$ at room or elevated tem- peratures, whereas substrates containing larger rings require more severe conditions. Monocyclic substrates are less reactive than bicyclic endoperoxides and require even more harsh conditions.

\section{Rearrangements and related processes of important natural and synthetic peroxides} 3.1 Antimalarial, antiparasitic, and antitumor peroxides

The extensive development of the chemistry of organic peroxides has been stimulated largely by the isolation of the antimalarial agent artemisinin from leaves of the annual wormwood Artemisia annua in 1972. The structural identification showed that artemisinin contains a cyclic endoperoxide moiety $(1,2,4-$ trioxane ring), which plays a key role in its antimalarial activity $[526,527]$. The highly reactive and unusual chemical structure, in addition to low yields isolated from natural sources gave impetus to the development of total synthesis methods of artemisinin. Several routes towards the total synthesis of this compound were elaborated and several semisynthetic derivatives were prepared [12,16,528-533]. The high costs of these products stimulated the search for alternative peroxides, which are synthetically easier accessible and less expensive compared with the natural and semisynthetic structures. It was shown that 1,2-dioxolanes [35], 1,2-dioxanes [40], 1,2,4-trioxolanes [534536], 1,2,4-trioxanes [44], and 1,2,4,5-tetraoxanes [537] exhibit antimalarial activity, which was sometimes higher than that of the parent artemisinin (Scheme 172). As a milestone of this research, arterolane, a fully synthetic 1,2,4-trioxolane was discovered and in 2012, the arterolane-based drug synriam was approved to the market. 
Table 31: $\mathrm{Pd}\left(\mathrm{PPh}_{3}\right)_{4}$-catalyzed transformation of 1,4-endoperoxides.

Endoperoxide $\quad$ Temperature, ${ }^{\circ} \mathrm{C}$ (time, h)

0

$611 \mathrm{a}$

O-O

611b

0
0

611c

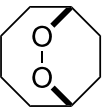

611d

$0 \hat{今}$
1
0,

530

Oे

261g

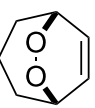

263<smiles>CCCC[C@H]1C=C[C@@H](CCCC)OO1</smiles>

$17(3)$

60 (5)

60 (10)

65 (15)

$4(20)$

50-60 (5)

60 (29)

60 (39)

$611 \mathrm{e}$

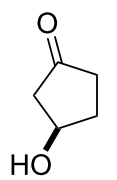

612a, 41<smiles>O=C1CC[C](O)CC1</smiles>

612b, 49

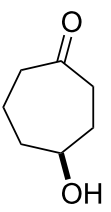

612c, 62<smiles>O=C1CCCC[C@H](O)CC1</smiles>

612d, 73

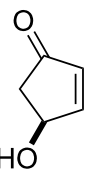

612e, 54<smiles>O=C1C=CC(O)CC1</smiles>

262g, 42<smiles>O=C1C=CC(O)CCC1</smiles>

612f, 45<smiles>CCCCC(=O)/C=C/[C@H](O)CCCC</smiles>

612g, 34
Products, \%
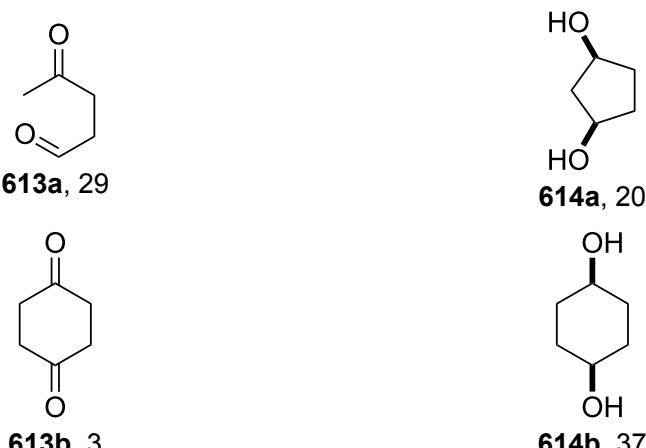

614b, 37

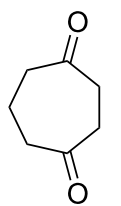

613c, 13<smiles>OC1CCCC(O)CC1</smiles>

614c, 25

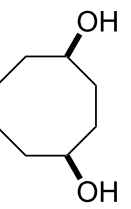

614d, 23

$\mathrm{HO}$

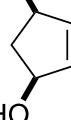

614e, 16<smiles>OC1C=CC(O)CC1</smiles>

614f, 32

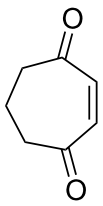

613d, 10<smiles>OC1C=CC(O)CCC1</smiles>

614g, 17

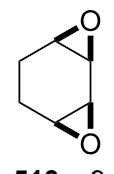

513a, 9
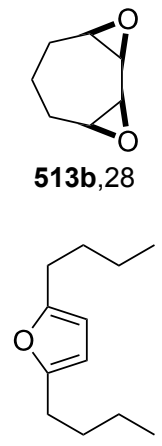

615, 5 
<smiles>CCCCCCCCCCCCCCCCC</smiles>

$611 f$<smiles>CCCCCCCCCCCCCCCCCCCC</smiles>

$611 \mathrm{~g}$
$100(15)$<smiles>CCCCCCCCCCCCCC(C)(C)O</smiles>

612h, 66

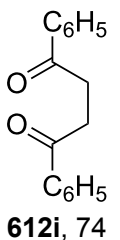

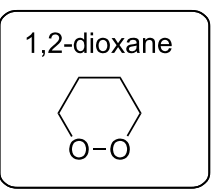

yingzhaosu

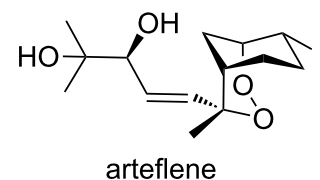<smiles>C[C@H]1C(=O)C[C@H]2C[C@@H]1OOC2(C)/C=C\c1ccc(C(F)(F)F)cc1C(F)(F)F</smiles>

13-carbaartemisinin

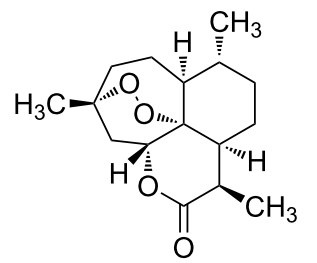

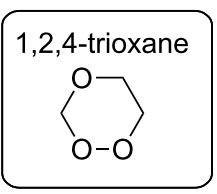

artemisinin

\section{1,2,4-trioxolane \\ $\mathrm{O}-\mathrm{O}$ \\ \langle\rangle}

arterolane

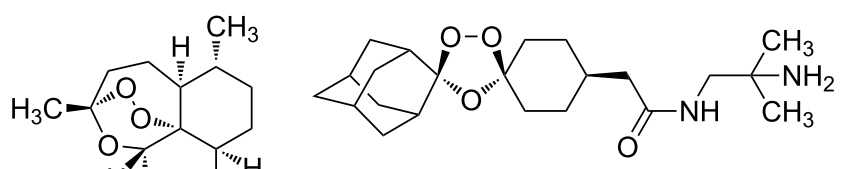

6,6'-dimethyltrioxane<smiles>CC1(C)COC2(CCC(=O)CC2)OO1</smiles>

1,2,4,5-tetraoxane<smiles>C1OOCOO1</smiles>

synthon of trioxaquines cis- 3 and trans -3

RKA 182

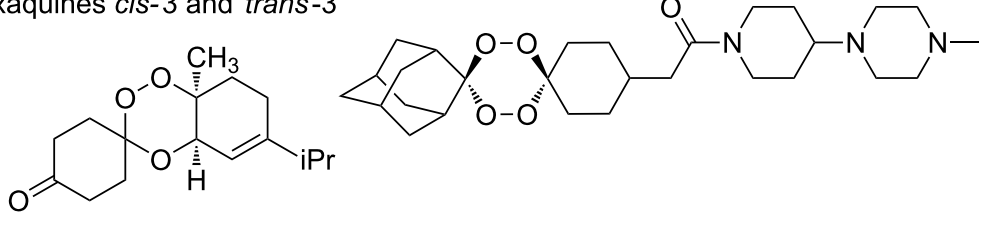

Scheme 172: Peroxides with antimalarial activity.

Although artemisinin has been used in medicine for about three decades, the mechanism of its action remains unclear [538,539]. Two main theories of its antiparasitic action are assumed. In accordance with one theory, the endoperoxide bond is reduced by means of iron ions leading to the formation of oxygen- centered radicals, which are responsible for the initiation of oxidative stress in infected erythrocytes. An alternative theory proposes that specific parasites' proteins or heme are alkylated by carbon-centered radicals derived from the peroxide [540,541]. In infected human erythrocytes, malaria parasites 
digest more than $70 \%$ of the hemoglobin with formation of globin and heme. After the hydrolysis of globin, the resulting amino acids are used by the parasites for protein synthesis. Malaria parasites detoxify the toxic heme via a heme polymerization process with preparation of hemozoin, which exists in the crystalline form. Parasite metalloproteins, superoxide dismutase and ferredoxin, use a small part of the host's iron for their construction. In such a manner parasite cells always contain heme iron and non-heme iron, allows for the interaction with artemisinin or other peroxides [542].

Numerous studies on the interaction of iron ions with artemisinin (616) demonstrated that $\mathrm{Fe}(\mathrm{II})$ promotes the O-Obond cleavage via two paths. Thus, $\mathrm{Fe}(\mathrm{II})$ may bind to either O1 or $\mathrm{O} 2$ in artemisinin (Scheme 173) [542-551]. The interaction of $\mathrm{Fe}(\mathrm{II})$ with $\mathrm{O} 1$ gives rise to an intermediate oxy radical 617a, which undergoes $\beta$-scission to form the primary $\mathrm{C}$-centered radical $\mathbf{6 1 7 b}$. The subsequent elimination of $\mathrm{Fe}(\mathrm{II})$ is accompanied by the formation of compound $\mathbf{6 1 8}$ containing a tetrahydrofuran ring. The pathway involving the interaction of $\mathrm{Fe}(\mathrm{II})$ with $\mathrm{O} 2$ affords the $\mathrm{O}$-centered radical 619a. A subsequent $[1,5]-\mathrm{H}$ shift results in the formation of the secondary $\mathrm{C}$-centered radical $\mathbf{6 1 9 b}$, and the $\beta$-scission of the latter produces vinyl ester 620, which can be epoxidated by the resulting high-valent iron-oxo species. Epoxide 621 is finally cyclized to hydroxydeoxoartemisinin $\mathbf{6 2 2}$. The formation of 618 and $\mathbf{6 2 2}$ is evidence in favor of the proposed two pathways of the Fe(II)-promoted transformation of artemisinin. The highly reactive intermediates $\mathbf{6 1 7}$ and $\mathbf{6 1 9}$ apparently lead to the damage of some parasite biomolecules [552].

The 1,2-dioxanes $\mathbf{6 2 3}$ and $\mathbf{6 2 4}$ exhibiting antimalarial activity were isolated from the Caribbean sponge Plakortis simplex and their reactions with $\mathrm{Fe}(\mathrm{II})$ result in compounds $625 \mathbf{a}, \mathbf{b}$ and 626a,b, respectively (Scheme 174) [553].

Scheme 175 shows the mechanism including the formation of oxygen radicals 627, 629 from cyclic peroxides 623 and 624 . The 1,5-rearrangement of the latter produces the alkyl-side chain carbon-centered radicals $\mathbf{6 2 8}, \mathbf{6 3 0}$. The reaction of these toxic intermediates with parasite biomolecules determines the biological effect observed for 1,2-dioxanes $\mathbf{6 2 3}$ and $\mathbf{6 2 4}$ (Scheme 175).

Depending on the nature of the substituents in close vicinity of the peroxide group, the bicyclic natural endoperoxides G3-factors 631-633 which are involved in plant defense and extracted from the leaves of Eucalyptus grandis, react with $\mathrm{Fe}(\mathrm{II})$ to form different types of products. For instance, treatment of the $\mathbf{6 3 1}$ with $\mathrm{Fe}(\mathrm{II}) \mathrm{SO}_{4}$, gives rise to $\mathbf{6 3 4}$ in $82 \%$ yield. On the other hand the reaction of $\mathbf{6 3 2}$ under the same reaction conditions affords three products $\mathbf{6 3 5}, \mathbf{6 3 6}$, and $\mathbf{6 3 7}$ in a 1:1:1 ratio. The fluorinated endoperoxide $\mathbf{6 3 3}$ gives exclusively $\mathbf{6 3 8}$ under these conditions (Scheme 176) [554,555].

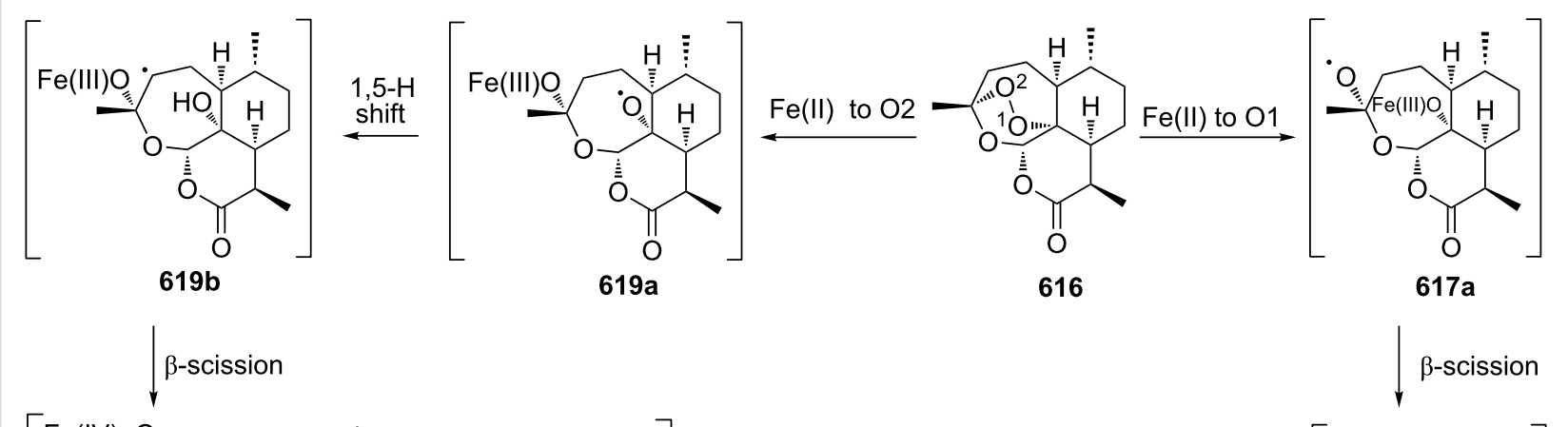

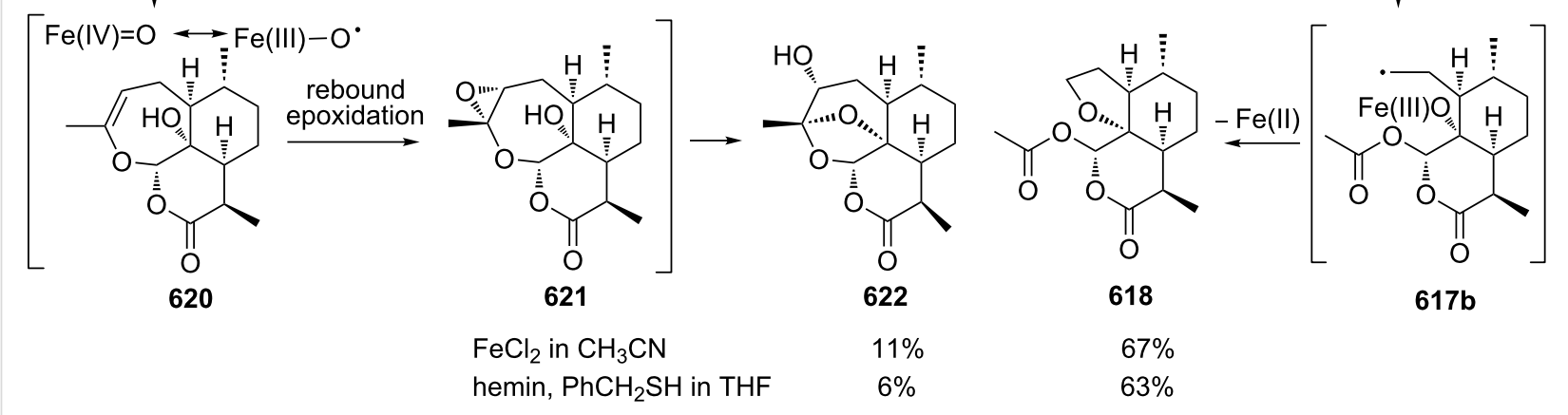


<smiles>CCCCC(CC)C[C@]1(C)CC(CC)C(CC(=O)OC)OO1</smiles>

623<smiles>CC/C=C/C(CC)C[C@]1(C)C[C@H](CC)C(CC(=O)OC)OO1</smiles>

624

$$
\begin{gathered}
\underset{\mathrm{FeCl}_{2} \text { (5 equiv) }}{\stackrel{\mathrm{CH}_{3} \mathrm{CN} / \mathrm{H}_{2} \mathrm{O} 4: 1}{2}} \\
2 \mathrm{~h}, \mathrm{rt}
\end{gathered}
$$

$$
\begin{gathered}
\underset{\mathrm{FeCl}_{3} \text { (5 equiv) }}{\mathrm{CH}_{\mathrm{H}} \mathrm{H}_{2} \mathrm{O} 4: 1} \\
2 \mathrm{~h}, \mathrm{rt}
\end{gathered}
$$

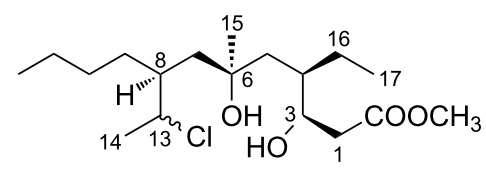

625a $13 R \quad 50 \%$ 625b $13 S \quad 8 \%$

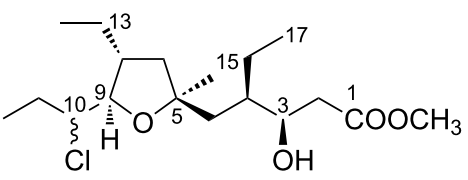

626a $10 R \quad 48 \%$ 626b $10 S \quad 23 \%$

Scheme 174: The interaction of $\mathrm{FeCl}_{2}$ with 1,2-dioxanes 623, 624<smiles>CCCCC(CC)C[C@]1(C)CC(CC)C(CC(=O)OC)OO1</smiles>

623<smiles>CCCC[C@H](C[C@](C)(O)C[C@H](CC)[C@@H](O)CC(=O)OC)[C@@H](C)Cl</smiles>

$625 a, b$<smiles>CC/C=C/[C@H](CC)C[C@]1(C)C[C@H](CC)[C@@H](CC(=O)OC)OO1</smiles>

624<smiles>CC[C@H](Cl)[C@H]1O[C@@](C)(C[C@H](CC)[C@@H](O)CC(=O)OC)C[C@H]1CC</smiles>

$626 a, b$

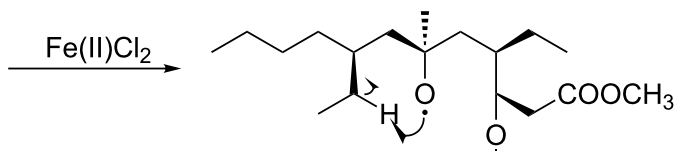

$627 \mathrm{I} \quad \mathrm{Fe}(\mathrm{III}) \mathrm{Cl}_{2}$

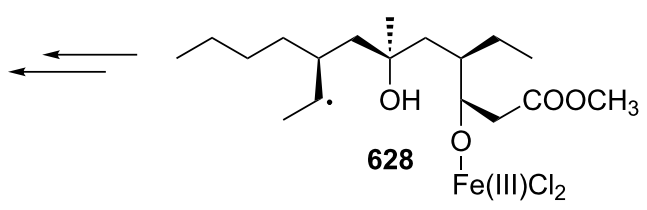

$\mathrm{Fe}(\mathrm{II}) \mathrm{Cl}_{2}$<smiles>CC/C=C1\CCO[C@](C)(C[C@@H](CC)[C@H](CC(=O)OC)OC(F)(Cl)Cl)C[C@H]1CC</smiles>

629

$\mathrm{Fe}(\mathrm{III}) \mathrm{Cl}_{2}$

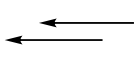

Scheme 175: The mechanism of reaction 623 and 624 with $\mathrm{Fe}(\mathrm{II}) \mathrm{Cl}_{2}$.

In the reaction with $\mathrm{Fe}(\mathrm{II})$, the natural antimalarial terpene cardamom peroxide 639 isolated from Amomum krervanh Pierre (Siam cardamom) is transformed into acids 640, 641, and 642 (Scheme 177) [164].

However, the cleavage of tetraoxane $\mathbf{6 4 3}$ gives two major products, namely 644 and 645 , in yields of $44 \%$ and $51 \%$, respec- tively. The reaction mechanism based on the results of this study is shown in Scheme 178 [556].

Presumably, in accordance with the direction from Fe(II) to O2, tetraoxane 646 interacts with iron(II) heme 647. Starting heme 647 reacts within $30 \mathrm{~min}$ with formation of three products. The LC-MS study proved the formation of the covalent coupling 
<smiles>CC1(C)C=C2C(=O)C(C)(C)C(=O)C(C)(C)C2(O)OO1</smiles><smiles>CCO[P+]([O-])(O)O[Na]</smiles>

631<smiles>COC12OOC(C)(C)C=C1C(=O)C(C)(C)C(=O)C2(C)C</smiles>

632<smiles>CC1(C)C=C2C(=O)C(C)(C)C(=O)C(C)(C)C2(F)OO1</smiles>

633<smiles>CC1(C)C(=O)C=C(C(=O)O)C(C)(C)C1=O</smiles>

\section{4}<smiles>COC(=O)C1=CC(=O)C(C)(C)C(=O)C1(C)C</smiles>

635<smiles>C=C(C)C(=O)C([CH2-])(C)C(=O)C1=CC([CH2-])(C)OC1=O</smiles>

636
637

Scheme 176: The reaction of bicyclic natural endoperoxides G3-factors $631-633$ with $\mathrm{FeSO}_{4}$.

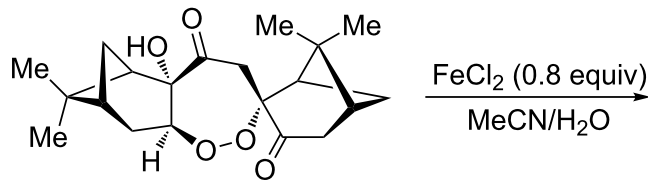

639<smiles>[3H][Mg][TeH]</smiles>

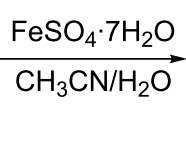<smiles>CC1(C)OC(=O)C2=C1C(=O)C(C)(C)C(=O)C2(C)C</smiles>

638<smiles></smiles>

$640,42 \%$<smiles>CC1(C)C2CC1C(O)[C@](O)(C(=O)C=C(O)[C@H]1C[C@H](CC(=O)O)C1(C)C)C(O)C2</smiles>

$641,20 \%$<smiles>CC1(C)[C@@H](C2=CC(=O)[C@@]3(O)[C@H](C[C@H]4C[C@H]3C4(C)C)O2)C[C@@H]1CC(=O)O</smiles>

642, $\sim 5$ to $10 \%$

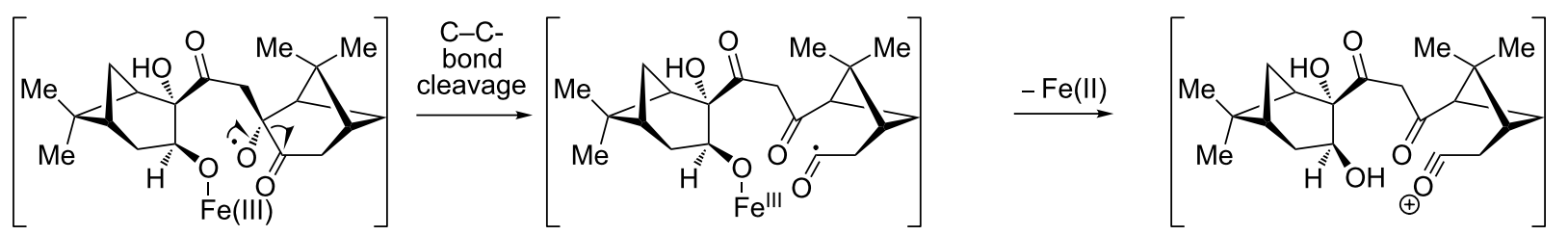

Scheme 177: The transformation of terpene cardamom peroxide 639.

product 648 formed from heme (mass 616) and the tetroxanederived secondary $\mathrm{C}$-centered radical. The molecular ion $[\mathrm{M}]^{+}$ of coupling product 648 was observed at $m / z 782.3$, which is consistent with the prediction (Scheme 179) $[537,556]$.
Under similar conditions, the same alkylated heme adduct was obtained with trioxolanes [557]. Four peaks at $m / z 782.3$ were detected which were assigned to the four possible regioisomers of alkylated heme adduct $\mathbf{6 4 8}$ as reported for heme-artemisinin 


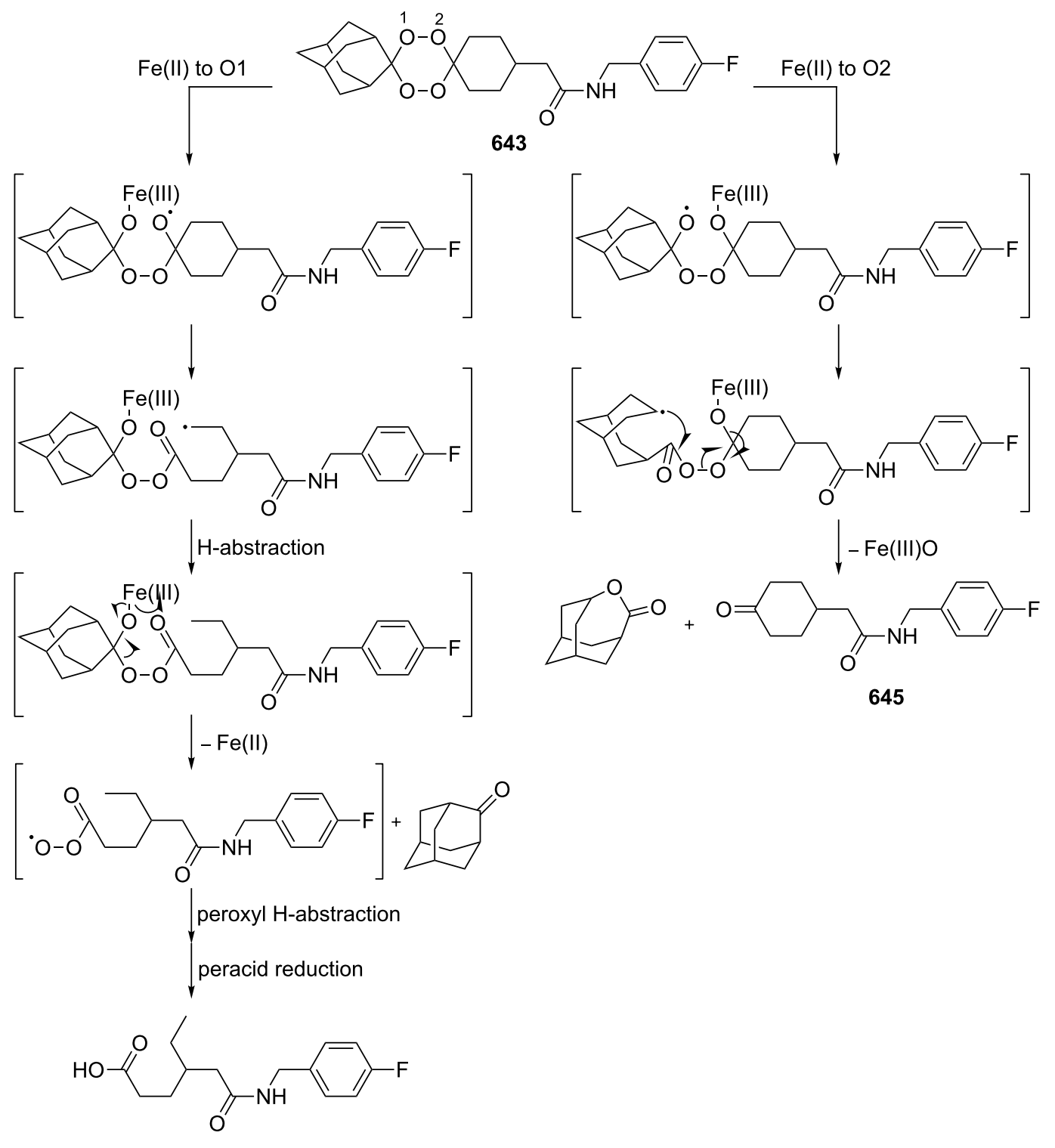

644

Scheme 178: The different ways of the cleavage of tetraoxane 643 .

adducts [558]. Later, in an initial study dealing with monoclonal antibodies that recognize the alkylation signature (sum of heme and protein alkylation) of synthetic peroxides it was shown that the artemisinins alkylate proteins in P. falciparum [559].

All the above-mentioned transformations involve the homolytic $\mathrm{O}-\mathrm{O}-$-bond cleavage resulting in the formation of an O-centered radical, which is followed by the rearrangement into a C-centered radical, as a key step. The subsequent transformation of the $\mathrm{C}$-centered radical determines the structure of the final product.
The peroxide, 3,6-epidioxy-1,10-bisaboladiene (EDBD, 649), isolated from wild plants, Cacalia delphiniifolia and Cacalia hastata, possesses cytotoxicity against the human promyelocytic leukemia cell line HL60. It was shown that the mechanism of biological activity of EDBD involves a rearrangement with formation of an unstable $\mathrm{C}$-centered radical intermediate 650, followed by its transformation into product $\mathbf{6 5 1}$ (Scheme 180) [560].

\subsection{Rearrangement of lipid peroxides}

Lipids contained in cell membranes maintain the structure and control of the vital functions of cells. Lipids are the targets of 


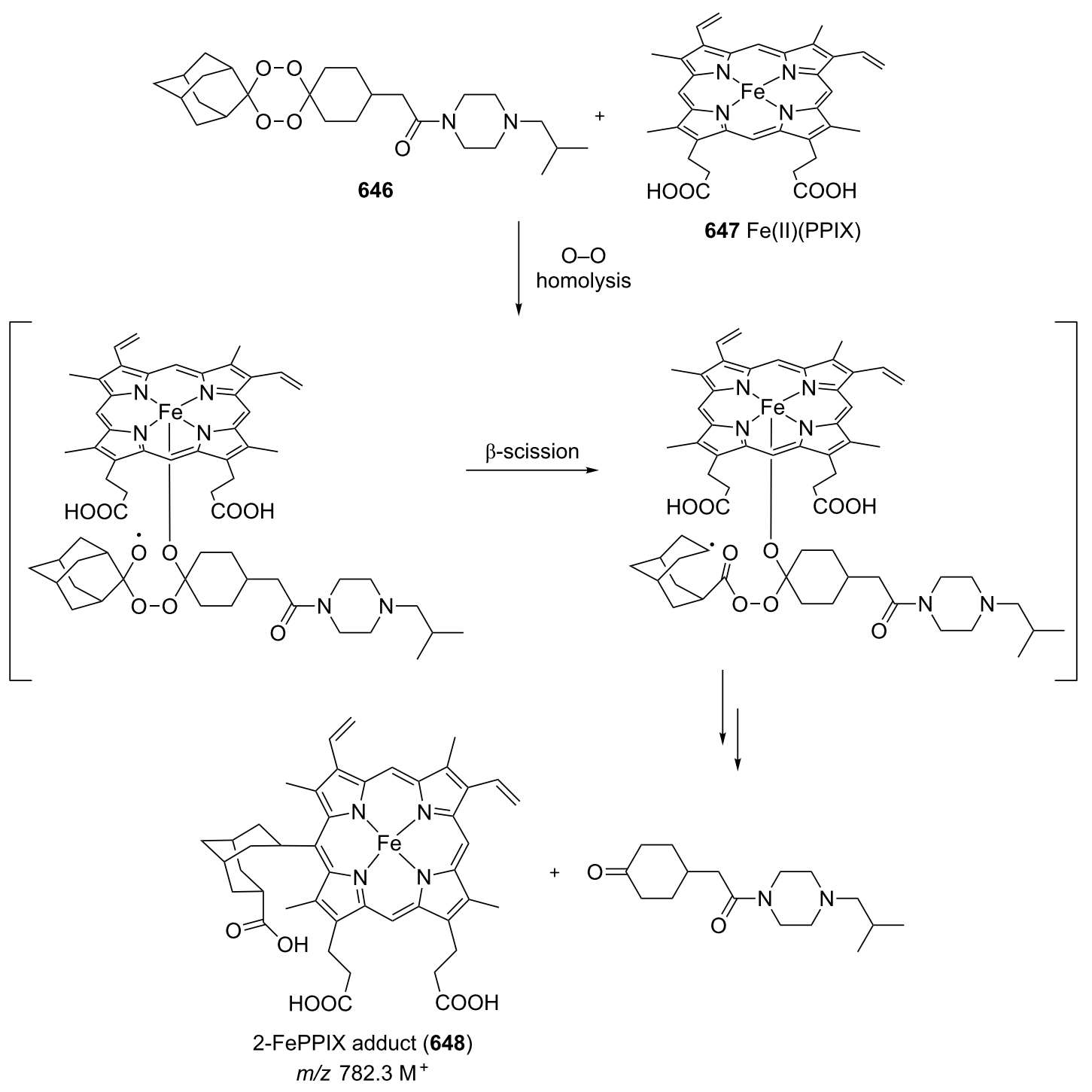

Scheme 179: The LC-MS analysis of interaction of tetraoxane 646 with iron(II)heme 647.

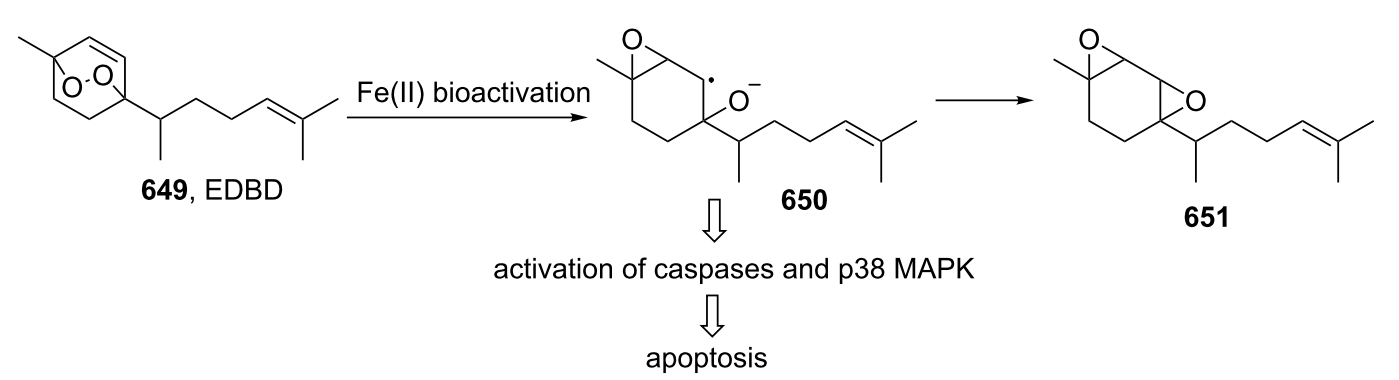

Scheme 180: The rearrangement of 3,6-epidioxy-1,10-bisaboladiene (EDBD, 649).

the reactions with reactive oxygen species (ROS) such as various oxygen-centered radicals, which play a key role in several pathological states [561]. Compounds containing double bonds, polyunsaturated fatty acids and esters, cholesterol and its derivatives easily undergo oxidation by action of oxygencentered radicals (Scheme 181) [562,563]. 


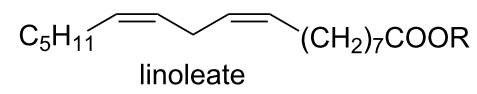

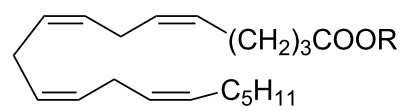

arachidonate

$$
\mathrm{C}_{8} \mathrm{H}_{17} \overbrace{\text { oleate }}\left(\mathrm{CH}_{2}\right)_{7} \mathrm{COOR}
$$

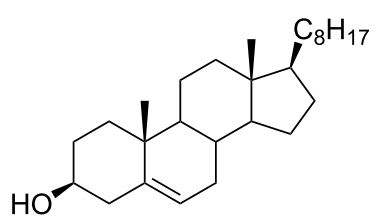

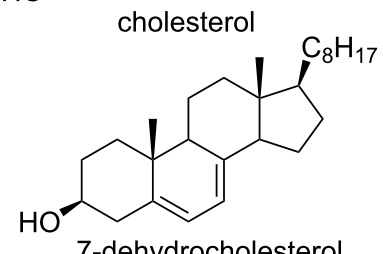

Scheme 181: Easily oxidized substrates.

Rearrangements of organic peroxides play an important role in such biological processes as the synthesis of prostaglandins from fatty acids. Prostaglandins are physiologically active substances produced by the reaction of arachidonic acid (652) with cyclooxygenase $(\mathrm{COX})$ isoenzymes. Prostaglandin $\mathrm{G}_{2}$ $\left(\mathrm{PGG}_{2}, \mathbf{6 5 3}\right)$ containing an endoperoxide fragment undergoes
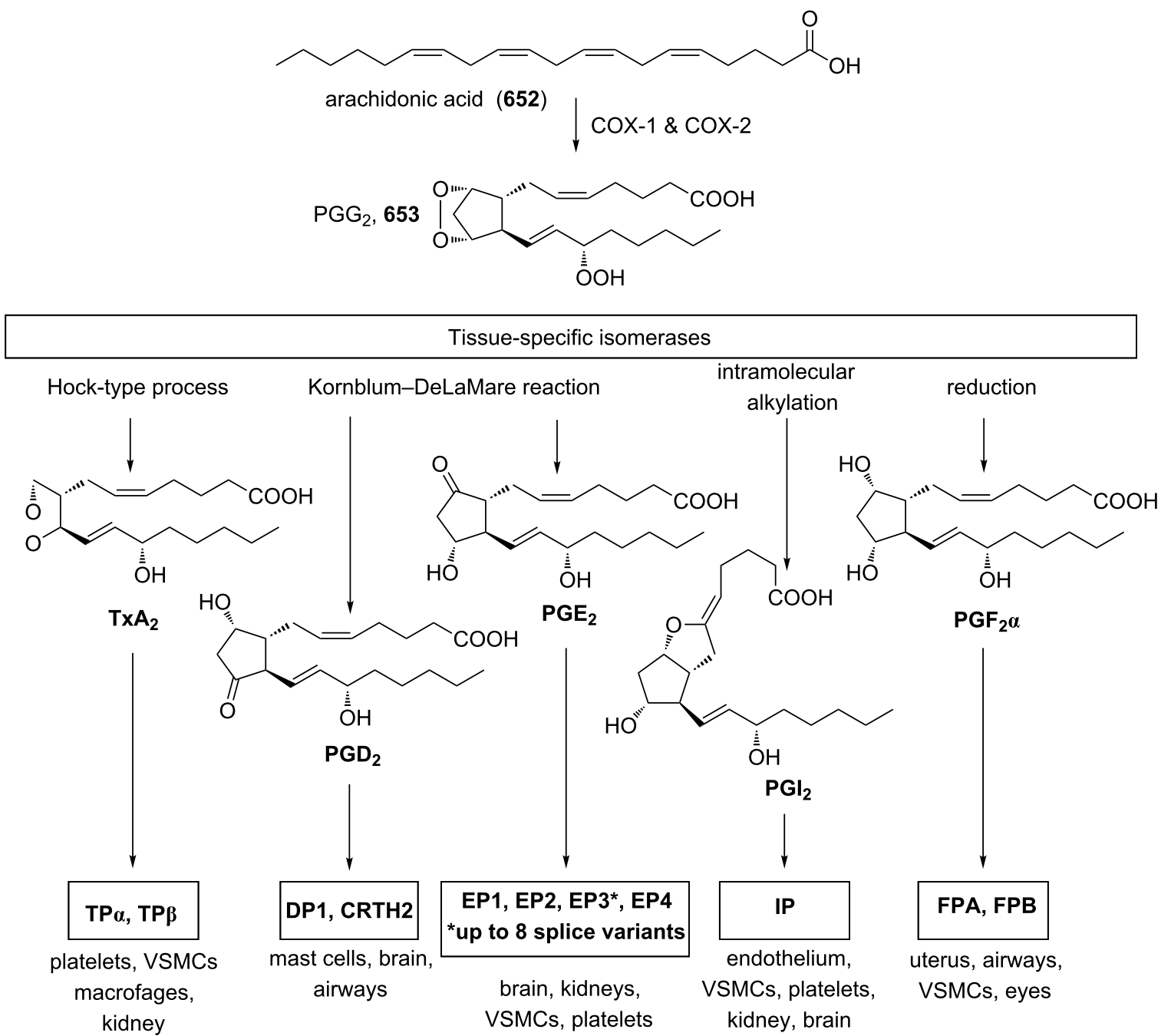

Scheme 182: Biopathway of synthesis of prostaglandins. 
transformations mediated by a series of specific isomerases and synthases with production of $\mathrm{PGE}_{2}, \mathrm{PGI}_{2}, \mathrm{PGD}_{2}, \mathrm{PGF}_{2}$, and $\mathrm{T}_{\mathrm{X}} \mathrm{A}_{2}$ (Scheme 182) [564-567].

The formation of the metabolites isoprostanes, neuroprostanes, phytoprostanes, and isofurans $\mathbf{6 5 5}-\mathbf{6 5 7}$ from fatty acids under autoxidative conditions in vivo involves both the reduction of peroxides and their rearrangements (Scheme 183). These compounds proved to be widespread in nature. Compounds 655-657 display significant biological activities, and the isoprostanes are currently the most reliable indicators of oxidative stress [568-570].

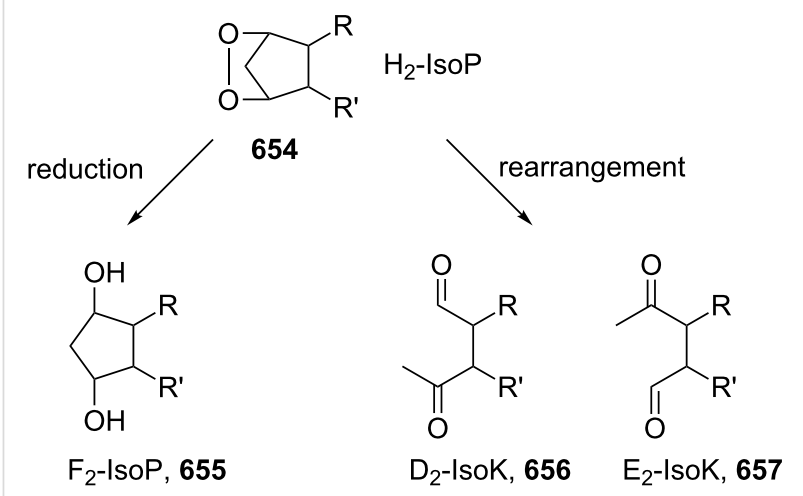

Scheme 183: The reduction and rearrangements of isoprostanes.

One of the essential fatty acids, linoleic acid, contains a homoconjugated diene fragment, which is responsible for a specific peroxidation mechanism without the formation of cyclic peroxides. In addition to linoleic acid, its esters are present in the human circulating low-density lipoprotein (LDL). For this reason, the oxidation of linoleic acid esters is of special biomedical interest [566]. A mechanism for linoleate (658) oxidation, which involves hydroperoxyoctadecadienoates (HPODE, 660-662) preparation, is presented in Scheme 184. The first step of the oxidation process is the formation of the carboncentered pentadienyl radical 659. The reaction of $\mathbf{6 5 9}$ with $\mathrm{O}_{2}$ produces three peroxyl radicals, one of them having a nonconjugated diene part with the oxygen at $\mathrm{C}-11$ position. The two other radicals have $Z, E$ - and $E, E$-conjugated diene parts with oxygen substituents at the C- 9 and C-13 positions. These peroxyl radical intermediates after abstracting hydrogen atoms transform to the hydroperoxyoctadecadienoates (HPODE, 660-662) [570].

The Hock cleavage mechanism is a possible route to transform lipid hydroperoxide 663 into smaller carbonyl compounds 664-666, although this transformation seems to occur only in the presence of photosensitizers (Scheme 185) [571].

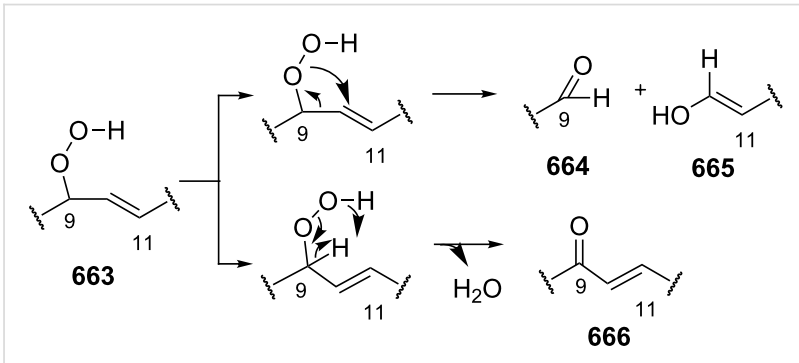

Scheme 185: The transformation of lipid hydroperoxide.

In mammalian tissues and cells, cholesterol is found to a large extent. One of the main cholesterol functions represents to maintaining the stability of plasma membranes. The oxidation

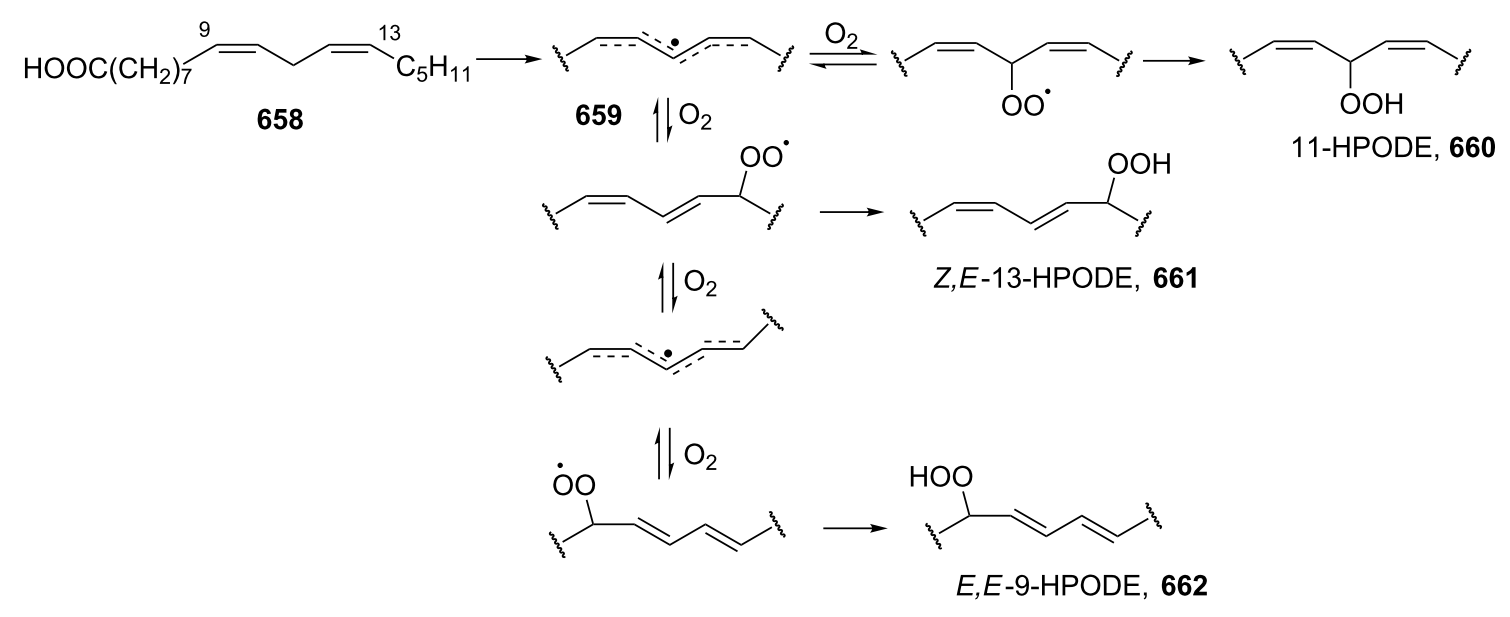


of cholesterol by means of free radical particles is responsible for the initiation of a range of pathological conditions $[572,573]$. Many processes including the rearrangement of intermediately formed peroxides accompany the oxidation of cholesterol. The major product of ${ }^{1} \mathrm{O}_{2}$ oxidation of cholesterol (667), cholesterol 5 $\alpha$-hydroperoxide (668), readily forms 5,6secosterol ketoaldehyde $\mathbf{6 6 9}$ and the product of its intramolecular aldolization 670 through an acid-catalyzed (Hock) cleavage of the C5-C6 bond in $\mathbf{6 6 8}$ (Scheme 186) [67].

\subsection{Rearrangement of dioxygenase enzyme-sub- strate systems}

A useful chemical property of most soil bacteria concludes in their capability to oxidize aromatic compounds. This multistep process depends on the structure of dioxygenase enzymes, which utilize molecular oxygen for oxidation [574]. This oxidation has attracted much attention as a green chemistry approach for the conversion of aromatic compounds to water-soluble products and for degradation of lignin [575,576]. The ring cleavage of 1,2-dihydroxybenzene (catechol) is likely the most thoroughly studied reaction which is catalyzed by iron-dependent catechol dioxygenase enzymes [577-579]. The oxidation of catechols 671 and 673 by two types of enzymes - intradiol dioxygenase and extradiol dioxygenase - affords 3-carboxyhexa-2,4-dienedioic acid (672) and 2-hydroxy-6-ketonona-2,4dienoic acid (674) (Scheme 187) [580,581].

A key step in the cleavage of the aromatic ring is the oxygenatom insertion into the $\mathrm{C}-\mathrm{C}$-double bond as the result of a Criegee-like or Hock-like intermediate rearrangement $[582,583]$. It was demonstrated that, despite the different mechanisms of the initial step of the substrate/molecular oxygen activation, both reactions produce hydroperoxide $\mathbf{6 7 5}$ as the intermediate. This hydroperoxide undergoes Criegee-like or Hocklike rearrangement through different pathways. Intradiol dioxygenase catalyzes the 1,2-acyl migration (path B) and the formation of an intermediate anhydride 677. On the other hand, extradiol dioxygenase catalyzes the 1,2-migration of the alkenyl moiety (path A) through the intermediate formation of lactone 676 (Scheme 188) [584].

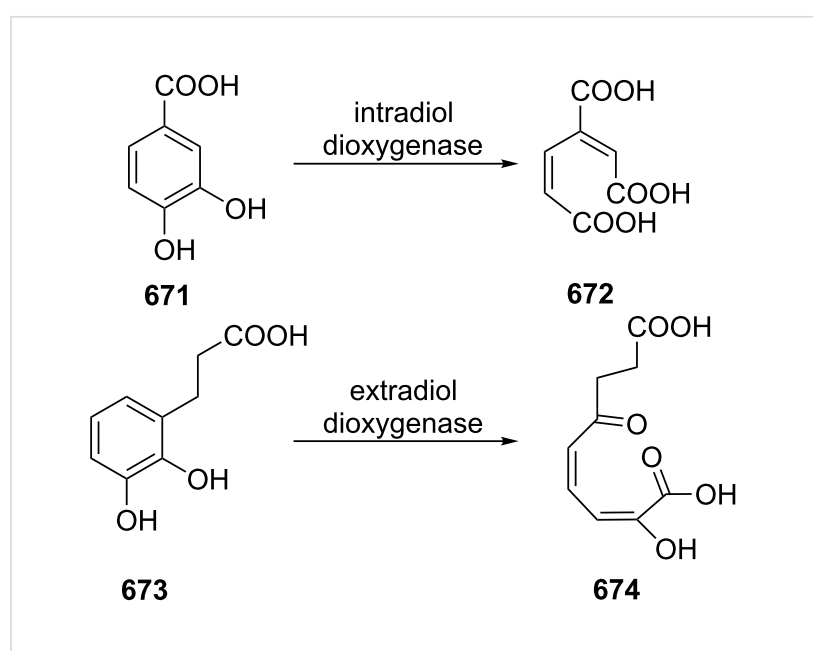

Scheme 187: Two pathways of catechols oxidation.

Therefore, the catalyst for the O-O-bond cleavage in the Criegee-like intermediate determines the regioselectivity of the catechol oxidation.

A similar rearrangement of the Criegee intermediate with the cleavage of the $\mathrm{C}-\mathrm{C}$ bond occurs in oxidative cleavage of natural organic pigments, carotinoides 679 by carotenoid cleavage dioxygenases (Scheme 189) [585,586].

In this section, we considered rearrangements of the most important natural and synthetic peroxides, which proceed or can take place in biological systems. Apparently, there are is a much larger number of biological processes, involving rearrangements of peroxides, which has to be discovered and studied in the future.

\section{Conclusion}

The rearrangements of organic peroxides and related processes are covered in the literature in hundreds of publications and several specialized reviews. However, these reviews are limited in scope, narrow in their approach, and do not provide an overall picture of this field of chemistry. The present review is the first to offer a complex analysis of the available data on re-

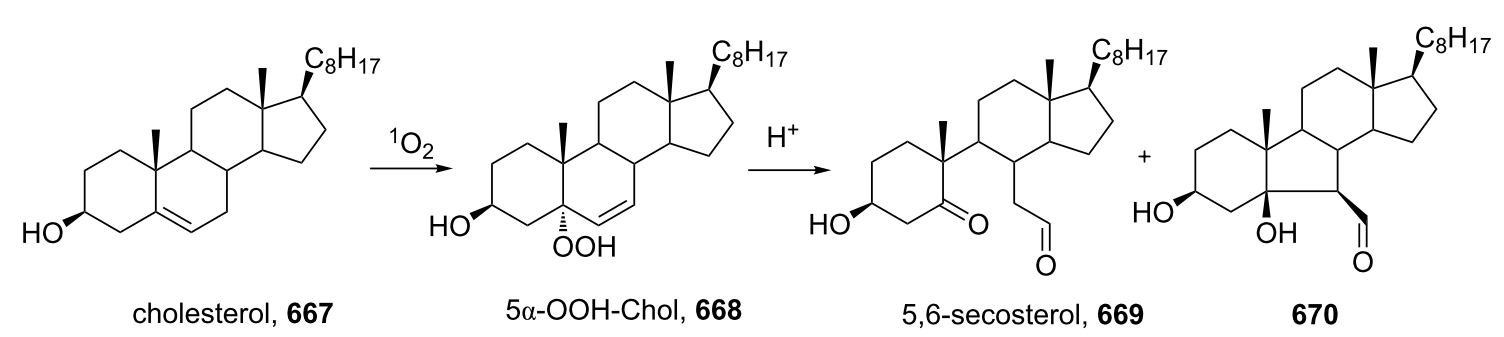




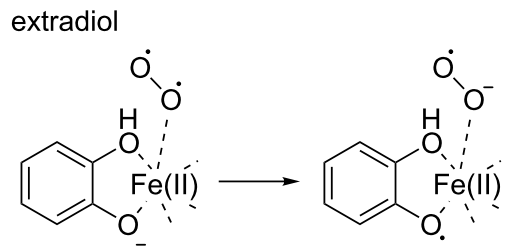

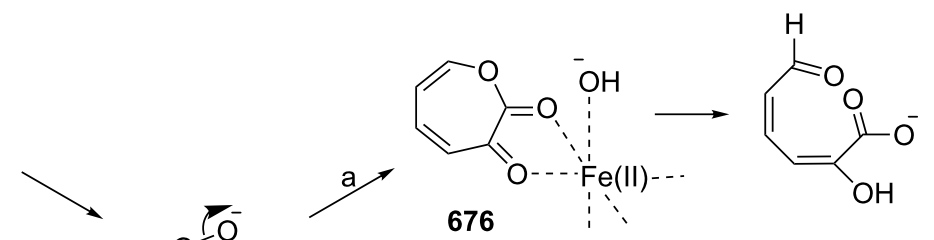<smiles>C[Si]1(C)Oc2ccc(cc2)O1</smiles>

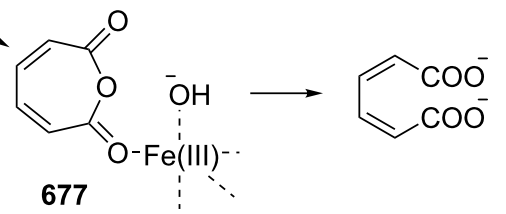<smiles>C#CS/C=C(C)/C=C/C=C(C)/C=C/C1=C(C)CCCC1(C)C</smiles>

$\beta, \beta$-carotene (678)<smiles>[R]C=C(C=CC=C(C)C=CC1(O)C(C)CC(O)CC1(C)C)CC</smiles>

(679)

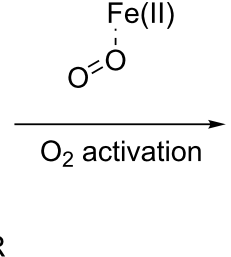

$\mathrm{Fe}(\mathrm{II})$ 
asymmetric synthesis, organocatalysis, and the use of transition metal-peroxo complexes for the preparation of compounds interesting for pharmacological applications. The published data summarized in the review provide, for the first time, an insight into the common and different features of the reaction mechanisms and allow predicting experimental and structural requirements for performing rearrangements with specified results. An analysis of the published data shows that there are numerous new and unnamed processes related to name reactions. The development and investigation of these processes are apparently the future of peroxide chemistry.

Rearrangements of organic peroxides are the key steps in processes such as the Baeyer-Villiger, the Criegee and Hock reactions, the Kornblum-DeLaMare rearrangement, and Dakin and Elbs oxidation reactions. These reactions are widely used in chemistry: The Baeyer-Villiger oxidation is widely used for the synthesis of esters and lactones. The Criegee reaction is employed to transform tertiary alcohols into ketones and aldehydes. The Kornblum-DeLaMare rearrangement is an important tool in the synthesis of $\gamma$-hydroxy enones. The Dakin oxidation is applied in the synthesis of phenols from arylaldehydes or aryl ketones and the Elbs persulfate oxidation is used to prepare hydroxyphenols from phenols.

The comprehensive analysis of the published data makes the knotty term "peroxide rearrangement" more exact. Two types of processes are actually included under the term "peroxide rearrangement": processes that fall under the definition of a classical rearrangement, resulting in the formation of a compound of isomeric structure, and processes, in which the $\mathrm{O}-\mathrm{O}-$ bond cleavage is followed by the rearrangement of one of the resulting fragments.

The pathways of peroxide rearrangements mainly depend on the type of the catalysts used, the reaction conditions, and the structure of the starting peroxide. Rearrangements can be accompanied by a homolytic or heterolytic O-O-bond cleavage, through the formation of a carbocation (e.g., the Criegee rearrangement), a carbanion (e.g., the Kornblum-DeLaMare rearrangement), or an O-centered radical (e.g., the Wieland rearrangement or rearrangements promoted by variable-valence metals).

In recent years, there has been a growing interest in organic peroxides as a base for the design of antiparasitic and antitumor agents, which led to an extensive search for new classes of peroxides. New compounds and new structural classes play a key role in the development of the chemistry of rearrangements and the performance of related useful transformations of peroxides.

\section{Acknowledgements}

This work was supported by the Russian Foundation for Basic Research (Grant no 16-29-10678).

\section{References}

1. Ando, W. Organic Peroxides; Wiley: Chichester, 1992.

2. Reetz, I.; Yagci, Y.; Mishra, M. K. Initiation of Vinyl Polymerization by Organic Molecules and Nonmetal Initiators. Handbook of Vinyl Polymers; CRC Press: Boca Raton, 2008; pp 27-48.

3. Flory, P. J. Principles of Polymer Chemistry; Cornell University Press: Ithaca, New York, 1953.

4. Denisov, E. T.; Denisova, T. G.; Pokidova, T. S. Handbook of free radical initiators; John Wiley \& Sons: New York, 2005.

5. Adam, W. Four-membered ring peroxides: 1,2-dioxetanes and a-peroxylactones. In Peroxides; Patai, S., Ed.; John Wiley \& Sons, Ltd.: Chichester, U.K., 1983; pp 829-920. doi:10.1002/9780470771730.ch24

6. Bouillon, G.; Lick, C.; Schank, K. Diacyl peroxides, peroxycarboxylic acids and peroxy esters. In Peroxides; Patai, S., Ed.; John Wiley \& Sons, Ltd.: Chichester, U.K., 1983; pp 279-309. doi:10.1002/9780470771730.ch10

7. Saito, I.; Nittala, S. S. Endoperoxides. In Peroxides; Patai, S., Ed.; John Wiley \& Sons, Ltd.: Chichester, U.K., 1983; pp 311-374. doi:10.1002/9780470771730.ch11

8. Sheldon, R. A. Synthesis and uses of alkyl hydroperoxides and dialkyl peroxides. In Peroxides; Patai, S., Ed.; John Wiley \& Sons, Ltd.: Chichester, U.K., 1983; pp 161-200. doi:10.1002/9780470771730.ch6

9. Adam, W. Peroxide Chemistry: Mechanistic and Preparative Aspects of Oxygen Transfer; Wiley-VCH: Weinheim, 2000. doi:10.1002/3527600396

10. World Health Organization. World Health Organization. World malaria report 2015; WHO Press, 2005. http://www.who.int/malaria/publications/world-malaria-report-2015/en/ (accessed July 4, 2016).

11. Jefford, C. W. Curr. Top. Med. Chem. 2012, 12, 373-399. doi:10.2174/156802612799362940

12. Slack, R. D.; Jacobine, A. M.; Posner, G. H. Med. Chem. Commun. 2012, 3, 281-297. doi:10.1039/c2md00277a

13. Muregi, F. W.; Ishih, A. Drug Dev. Res. 2010, 71, 20-32. doi:10.1002/ddr.20345

14. Fernández, I.; Robert, A. Org. Biomol. Chem. 2011, 9, 4098-4107. doi:10.1039/c1ob05088e

15. Chadwick, J.; Amewu, R. K.; Marti, F.; Bousejra-El Garah, F.; Sharma, R.; Berry, N. G.; Stocks, P. A.; Burrell-Saward, H.; Wittlin, S. Rottmann, M.; Brun, R.; Taramelli, D.; Parapini, S.; Ward, S. A.; O'Neill, P. M. ChemMedChem 2011, 6, 1357-1361. doi:10.1002/cmdc.201100196

16. Opsenica, D. M.; Šolaja, B. A. J. Serb. Chem. Soc. 2009, 74 1155-1193. doi:10.2298/JSC09111550

17. Ghorai, P.; Dussault, P. H.; Hu, C. Org. Lett. 2008, 10, 2401-2404. doi:10.1021/ol800657m

18. Dong, Y. Mini-Rev. Med. Chem. 2002, 2, 113-123. doi:10.2174/1389557024605537

19. Vennerstrom, J. L.; Fu, H. N.; Ellis, W. Y.; Ager, A. L., Jr.; Wood, J. K.; Andersen, S. L.; Gerena, L.; Milhous, W. K. J. Med. Chem. 1992, 35, 3023-3027. doi:10.1021/jm00094a015

20. Yadav, N.; Sharma, C.; Awasthi, S. K. RSC Adv. 2014, 4, 5469-5498. doi:10.1039/c3ra42513d 
21. Terent'ev, A. O.; Borisov, D. A.; Yaremenko, I. A. Chem. Heterocycl. Compd. 2012, 48, 55-58. doi:10.1007/s10593-012-0969-3

22. Hao, H.-D.; Wittlin, S.; Wu, Y. Chem. - Eur. J. 2013, 19, 7605-7619. doi:10.1002/chem.201300076

23. Li, Y.; Hao, H.-D.; Wittlin, S.; Wu, Y. Chem. - Asian J. 2012, 7, 1881-1886. doi:10.1002/asia.201200166

24. Boissier, J.; Portela, J.; Pradines, V.; Coslédan, F.; Robert, A.; Meunier, B. C. R. Chim. 2012, 15, 75-78. doi:10.1016/j.crci.2011.11.008

25. Keiser, J.; Veneziano, V.; Rinaldi, L.; Mezzino, L.; Duthaler, U.; Cringoli, G. Res. Vet. Sci. 2010, 88, 107-110. doi:10.1016/j.rvsc.2009.05.007

26. Keiser, J.; Ingram, K.; Vargas, M.; Chollet, J.; Wang, X.; Dong, Y.; Vennerstrom, J. L. Antimicrob. Agents Chemother. 2012, 56, 1090-1092. doi:10.1128/AAC.05371-11

27. Shuhua, X.; Tanner, M.; N'Goran, E. K.; Utzinger, J.; Chollet, J.; Bergquist, R.; Minggang, C.; Jiang, Z. Acta Trop. 2002, 82, 175-181. doi:10.1016/S0001-706X(02)00009-8

28. Ingram, K.; Yaremenko, I. A.; Krylov, I. B.; Hofer, L.; Terent'ev, A. O.; Keiser, J. J. Med. Chem. 2012, 55, 8700-8711. doi:10.1021/jm3009184

29. Dembitsky, V. M. Eur. J. Med. Chem. 2008, 43, 223-251. doi:10.1016/j.ejmech.2007.04.019

30. Dembitsky, V. M.; Gloriozova, T. A.; Poroikov, V. V. Mini-Rev. Med. Chem. 2007, 7, 571-589. doi:10.2174/138955707780859396

31. del Sol Jimenez, M.; Garzón, S. P.; Rodriguez, A. D. J. Nat. Prod. 2003, 66, 655-661. doi:10.1021/np030021h

32. Posner, G. H.; D’Angelo, J.; MO'Neill, P.; Mercer, A. Expert Opin. Ther. Pat. 2006, 16, 1665-1672. doi:10.1517/13543776.16.12.1665

33. Lai, H. C.; Singh, N. P.; Sasaki, T. Invest. New Drugs 2013, 31 , 230-246. doi:10.1007/s10637-012-9873-z

34. Dwivedi, A.; Mazumder, A.; du Plessis, L.; du Preez, J. L.; Haynes, R. K.; du Plessis, J. Nanomedicine 2015, 11, 2041-2050. doi:10.1016/j.nano.2015.07.010

35. Martyn, D. C.; Ramirez, A. P.; Berattie, M. J.; Cortese, J. F.; Patel, V.; Rush, M. A.; Woerpel, K. A.; Clardy, J. Bioorg. Med. Chem. Lett. 2008, 18, 6521-6524. doi:10.1016/j.bmcl.2008.10.083

36. Schiaffo, C. E.; Rottman, M.; Wittlin, S.; Dussault, P. H. ACS Med. Chem. Lett. 2011, 2, 316-319. doi:10.1021/ml100308d

37. Ingram, K.; Schiaffo, C. E.; Sittiwong, W.; Benner, E.; Dussault, P. H.; Keiser, J. J. Antimicrob. Chemother. 2012, 67, 1979-1986. doi:10.1093/jac/dks141

38. Wang, X.; Dong, Y.; Wittlin, S.; Charman, S. A.; Chiu, F. C. K.; Chollet, J.; Katneni, K.; Mannila, J.; Morizzi, J.; Ryan, E.; Scheurer, C.; Steuten, J.; Santo Tomas, J.; Snyder, C.; Vennerstrom, J. L. J. Med. Chem. 2013, 56, 2547-2555. doi:10.1021/jm400004u

39. Chaudhary, S.; Sharma, V.; Jaiswal, P. K.; Gaikwad, A. N.; Sinha, S. K.; Puri, S. K.; Sharon, A.; Maulik, P. R.; Chaturvedi, V. Org. Lett. 2015, 17, 4948-4951. doi:10.1021/acs.orglett.5b02296

40. O'Neill, P. M.; Stocks, P. A.; Pugh, M. D.; Araujo, N. C.; Korshin, E. E.; Bickley, J. F.; Ward, S. A.; Bray, P. G.; Pasini, E.; Davies, J.; Verissimo, E.; Bachi, M. D. Angew. Chem., Int. Ed. 2004, 43, 4193-4197. doi:10.1002/anie.200453859

41. Holla, H.; Labaied, M.; Pham, N.; Jenkins, I. D.; Stuart, K.; Quinn, R. J. Bioorg. Med. Chem. Lett. 2011, 21, 4793-4797. doi:10.1016/j.bmcl.2011.06.059
42. Lombardo, M.; Sonawane, D. P.; Quintavalla, A.; Trombini, C.; Dhavale, D. D.; Taramelli, D.; Corbett, Y.; Rondinelli, F.; Fattorusso, C.; Persico, M.; Taglialatela-Scafati, O. Eur. J. Org. Chem. 2014, 1607-1614. doi:10.1002/ejoc.201301394

43. Givelet, C.; Bernat, V.; Danel, M.; André-Barrès, C.; Vial, H. Eur. J. Org. Chem. 2007, 3095-3101. doi:10.1002/ejoc.200700086

44. Amewu, R.; Gibbons, P.; Mukhtar, A.; Stachulski, A. V.; Ward, S. A.; Hall, C.; Rimmer, K.; Davies, J.; Vivas, L.; Bacsa, J.; Mercer, A. E.; Nixon, G.; Stocks, P. A.; O'Neill, P. M. Org. Biomol. Chem. 2010, 8, 2068-2077. doi:10.1039/b924319d

45. Reiter, C.; Fröhlich, T.; Zeino, M.; Marschall, M.; Bahsi, H.; Leidenberger, M.; Friedrich, O.; Kappes, B.; Hampel, F.; Efferth, T.; Tsogoeva, S. B. Eur. J. Med. Chem. 2015, 97, 164-172. doi:10.1016/j.ejmech.2015.04.053

46. World Health Organization; Management of severe malaria - A practical handbook, 3rd ed.; WHO Press: 2013. http://www.who.int/malaria/publications/atoz/9789241548526/en/ (accessed July 4, 2016).

47. World Health Organization; Guidelines for the treatment of malaria, 3rd ed.; WHO Press, 2015. http://www.who.int/malaria/publications/atoz/9789241549127/en/ (accessed July 4, 2016).

48. Johnson, R. A.; Sharpless, K. B. Addition Reactions with Formation of Carbon-Oxygen Bonds: (ii) Asymmetric Methods of Epoxidation. In Comprehensive Organic Synthesis; Fleming, B. M. T., Ed.; Pergamon Press: Oxford, 1991; pp 389-436. doi:10.1016/B978-0-08-052349-1.00196-7

49. Baer, H.; Bergamo, M.; Forlin, A.; Pottenger, L. H.; Lindner, J. Propylene Oxide. Ullmann's Encyclopedia of Industrial Chemistry; Wiley-VCH: Weinheim, Germany, 2012. doi:10.1002/14356007.a22_239.pub3

50. Sienel, G.; Rieth, R.; Rowbottom, K. T. Epoxides. Ullmann's Encyclopedia of Industrial Chemistry; Wiley-VCH, 2000. doi:10.1002/14356007.a09_531

51. Wang, Z. Prilezhaev Reaction. Comprehensive Organic Name Reactions and Reagents; John Wiley \& Sons, Inc., 2010; pp 2270-2274. doi:10.1002/9780470638859.conrr513

52. Weber, M.; Weber, M.; Kleine-Boymann, M. Phenol. Ullmann's Encyclopedia of Industrial Chemistry; Wiley-VCH, 2000. doi:10.1002/14356007.a19_299.pub2

53. Schmidt, R. J. Appl. Catal., A 2005, 280, 89-103. doi:10.1016/j.apcata.2004.08.030

54. Weissermel, K.; Arpe, H.-J. Benzene Derivatives. Industrial Organic Chemistry; Wiley-VCH, 2008; pp 337-385. doi:10.1002/9783527619191.ch13

55. Ritz, J.; Fuchs, H.; Kieczka, H.; Moran, W. C. Caprolactam. Ullmann's Encyclopedia of Industrial Chemistry; Wiley-VCH, 2000. doi:10.1002/14356007.a05_031

56. Vollhardt, K. P. C.; Schore, N. E. Organic Chemistry: Structure and Function, 7th ed.; W. H. Freeman and Company, 2014.

57. Poth, U. Drying Oils and Related Products. Ullmann's Encyclopedia of Industrial Chemistry; Wiley-VCH, 2000. doi:10.1002/14356007.a09_055

58. Mallégol, J.; Gardette, J.-L.; Lemaire, J. J. Am. Oil Chem. Soc. 2000, 77, 249-255. doi:10.1007/s11746-000-0041-5

59. van Gorkum, R.; Bouwman, E. Coord. Chem. Rev. 2005, 249, 1709-1728. doi:10.1016/j.ccr.2005.02.002

60. Juita; Dlugogorski, B. Z.; Kennedy, E. M.; Mackie, J. C. Fire Sci. Rev. 2012, 1, No. 3. doi:10.1186/2193-0414-1-3 
61. Oakley, L. H.; Casadio, F.; Shull, K. R.; Broadbelt, L. J. Appl. Phys. A 2015, 121, 869-878. doi:10.1007/s00339-015-9363-1

62. Roda, A. Chemiluminescence and bioluminescence: past, present and future; RSC Press: Cambridge, 2010. doi:10.1039/9781849732024

63. Dodeigne, C.; Thunus, L.; Lejeune, R. Talanta 2000, 51, 415-439. doi:10.1016/S0039-9140(99)00294-5

64. Ciardelli, F.; Ruggeri, G.; Pucci, A. Chem. Soc. Rev. 2013, 42, 857-870. doi:10.1039/C2CS35414D

65. Roda, A.; Mirasoli, M.; Michelini, E.; Di Fusco, M.; Zangheri, M.; Cevenini, L.; Roda, B.; Simoni, P. Biosens. Bioelectron. 2016, 76, 164-179. doi:10.1016/j.bios.2015.06.017

66. Takeuchi, C.; Galvé, R.; Nieva, J.; Witter, D. P.; Wentworth, A. D.; Troseth, R. P.; Lerner, R. A.; Wentworth, P., Jr. Biochemistry 2006, 45, 7162-7170. doi:10.1021/bi0604330

67. Brinkhorst, J.; Nara, S. J.; Pratt, D. A. J. Am. Chem. Soc. 2008, 130, 12224-12225. doi:10.1021/ja804162d

68. Murphy, R. C.; Johnson, K. M. J. Biol. Chem. 2008, 283, 15521-15525. doi:10.1074/jbc.R700049200

69. Terao, J.; Minami, Y.; Bando, N. J. Clin. Biochem. Nutr. 2011, 48, 57-62. doi:10.3164/jcbn.11-008FR

70. Terao, J. Cholesterol Hydroperoxides and Their Degradation Mechanism. In Lipid Hydroperoxide-Derived Modification of Biomolecules; Kato, Y., Ed.; Springer: Netherlands, 2014; Vol. 77, pp 83-91. doi:10.1007/978-94-007-7920-4_7

71. Havaux, M. Plant J. 2014, 79, 597-606. doi:10.1111/tpj.12386

72. Milas, N. A.; Mageli, O. L.; Golubovic, A.; Arndt, R. W.; Ho, J. C. J. J. Am. Chem. Soc. 1963, 85, 222-226. doi:10.1021/ja00885a022

73. Rieche, A.; Bischoff, C. Chem. Ber. 1962, 95, 77-82. doi:10.1002/cber.19620950115

74. Criegee, R. Organic Peroxides; Wiley-Interscience: New York, London, 1972.

75. Cocker, W.; Grayson, D. H. J. Chem. Soc., Perkin Trans. 1 1975, 1347-1352. doi:10.1039/P19750001347

76. Vinogradova, L. P.; Zav'yalov, S. I. Izv. Akad. Nauk SSSR, Ser. Khim. 1961, 2050-2054.

Chem. Abstr. 1962, 57, 12344c.

77. Vinogradova, L. P.; Zav'yalov, S. I. Izv. Akad. Nauk SSSR, Ser. Khim. 1961, 1482-1486.

Chem. Abstr. 1962, 56, 338b.

78. Vinogradova, L. P.; Rudenko, B. A.; Zav'yalov, S. I. Izv. Akad. Nauk SSSR, Ser. Khim. 1962, 1436-1441. Chem. Abstr. 1963, 58, 2378g.

79. Rieche, A.; Bischoff, C.; Prescher, D. Chem. Ber. 1964, 97, 3071-3075. doi:10.1002/cber.19640971116

80. Rieche, A.; Seyfarth, H. E.; Brand, F. Justus Liebigs Ann. Chem. 1969, 725, 93-98. doi:10.1002/jlac.19697250112

81. Wolffenstein, R. Ber. Dtsch. Chem. Ges. 1895, 28, 2265-2269. doi:10.1002/cber.189502802208

82. Criegee, R.; Schnorrenberg, W.; Becke, J. Justus Liebigs Ann. Chem. 1949, 565, 7-21. doi:10.1002/jlac.19495650103

83. Dickey, F. H.; Rust, F. F.; Vaughan, W. E. J. Am. Chem. Soc. 1949, 71, 1432-1434. doi:10.1021/ja01172a081

84. Criegee, R.; Metz, K. Chem. Ber. 1956, 89, 1714-1718. doi:10.1002/cber.19560890720

85. Hawkins, E. G. E. J. Chem. Soc. C 1969, 2663-2670. doi:10.1039/j39690002663

86. Hawkins, E. G. E. J. Chem. Soc. C 1969, 2671-2677. doi:10.1039/j39690002671

87. Hawkins, E. G. E. J. Chem. Soc. C 1969, 2678-2681. doi:10.1039/j39690002678
88. Hawkins, E. G. E. J. Chem. Soc. C 1969, 2682-2686. doi:10.1039/j39690002682

89. Hawkins, E. G. E. J. Chem. Soc. C 1969, 2686-2691. doi:10.1039/j39690002686

90. Hawkins, E. G. E. J. Chem. Soc. C 1969, 2691-2697. doi:10.1039/j39690002691

91. Milas, N. A.; Golubović, A. J. Am. Chem. Soc. 1959, 81, 6461-6462. doi:10.1021/ja01533a033

92. Rieche, A. Angew. Chem. 1958, 70, 251-266. doi:10.1002/ange.19580700902

93. Edwards, J. O.; Sauer, M. C. V. J. Phys. Chem. 1971, 75, 3004-3011. doi:10.1021/j100688a023

94. Hine, J.; Redding, R. W. J. Org. Chem. 1970, 35, 2769-2772. doi:10.1021/jo00833a065

95. Jefford, C. W.; Jaggi, D.; Kohmoto, S.; Boukouvalas, J.; Bernardinelli, G. Helv. Chim. Acta 1984, 67, 2254-2260. doi:10.1002/hlca.19840670831

96. Singh, C. Tetrahedron Lett. 1990, 31, 6901-6902. doi:10.1016/S0040-4039(00)97202-2

97. Jefford, C. W.; Li, Y.; Jaber, A.; Boukouvalas, J. Synth. Commun. 1990, 20, 2589-2596. doi:10.1080/00397919008051466

98. Antonovskii, V. L.; Fedorova, E. V.; Shtivel, N. E.; Emelin, Y. D. Zh. Org. Khim. 1991, 27, 820-823.

99. Avery, M. A.; Gao, F.; Chong, W. K. M.; Hendrickson, T. F.; Inman, W. D.; Crews, P. Tetrahedron 1994, 50, 957-972. doi:10.1016/S0040-4020(01)80810-3

100.Rieche, A.; Bischoff, C.; Dietrich, P. Chem. Ber. 1961, 94, 2932-2936. doi:10.1002/cber.19610941115

101.Shreibert, A. I.; Chardin, A. P.; Pil'dus, I. E.; Ermarchenko, V. I. Zh. Org. Khim. 1971, 7, 967-971.

102. Razuvaev, G. A.; Dodonov, V. A.; Zaburdyaeva, S. N. Zh. Org. Khim. 1968, 4, 1302-1303.

J. Org. Chem. USSR (Eng. Trans.) 1968, 4, 1256-1257.

103. Dussault, P. H.; Lee, I. Q. J. Am. Chem. Soc. 1993, 115, 6458-6459. doi:10.1021/ja00067a090

104.Dussault, P. H.; Eary, C. T. J. Am. Chem. Soc. 1998, 120 , 7133-7134. doi:10.1021/ja9808503

105.Dussault, P. H.; Lee, H.-J.; Niu, Q. J. J. Org. Chem. 1995, 60, 784-785. doi:10.1021/jo00109a001

106. Kuznetsov, M. L.; Rocha, B. G. M.; Pombeiro, A. J. L.; Shul'pin, G. B. ACS Catal. 2015, 5, 3823-3835. doi:10.1021/acscatal.5b00077

107.Wang, C.; Yamamoto, H. J. Am. Chem. Soc. 2014, 136, 1222-1225. doi:10.1021/ja411379e

108. Bunge, A.; Hamann, H.-J.; Dietz, D.; Liebscher, J. Tetrahedron 2013, 69, 2446-2450. doi:10.1016/j.tet.2013.01.032

109. Jadhav, V. H.; Bande, O. P.; Puranik, V. G.; Dhavale, D. D. Tetrahedron: Asymmetry 2010, 21, 163-170. doi:10.1016/j.tetasy.2010.01.007

110. Cussó, O.; Garcia-Bosch, I.; Ribas, X.; Lloret-Fillol, J.; Costas, M. J. Am. Chem. Soc. 2013, 135, 14871-14878. doi:10.1021/ja4078446

111. Nieto, N.; Munslow, I. J.; Fernández-Pérez, H.; Vidal-Ferran, A. Synlett 2008, 2856-2858. doi:10.1055/s-0028-1083545

112. Burke, C. P.; Shi, Y. J. Org. Chem. 2007, 72, 4093-4097. doi:10.1021/jo070205r

113.Lifchits, O.; Mahlau, M.; Reisinger, C. M.; Lee, A.; Farès, C.; Polyak, I.; Gopakumar, G.; Thiel, W.; List, B. J. Am. Chem. Soc. 2013, 135, 6677-6693. doi:10.1021/ja402058v

114.Wang, L.; Sha, W.; Dai, Q.; Feng, X.; Wu, W.; Peng, H.; Chen, B.; Cheng, J. Org. Lett. 2014, 16, 2088-2091. doi:10.1021/ol500277u 
115.Dragan, A.; Kubczyk, T. M.; Rowley, J. H.; Sproules, S.; Tomkinson, N. C. O. Org. Lett. 2015, 17, 2618-2621. doi:10.1021/acs.orglett.5b00953

116.Chen, H.-H.; Wang, G.-Z.; Han, J.; Xu, M.-Y.; Zhao, Y.-Q.; Xu, H.-J. Tetrahedron 2014, 70, 212-217. doi:10.1016/j.tet.2013.11.085

117.Gogoi, A.; Modi, A.; Guin, S.; Rout, S. K.; Das, D.; Patel, B. K. Chem. Commun. 2014, 50, 10445-10447. doi:10.1039/C4CC04407J

118.Wu, X.-F.; Gong, J.-L.; Qi, X. Org. Biomol. Chem. 2014, 12, 5807-5817. doi:10.1039/C4OB00276H

119.Zhao, J.; Fang, H.; Han, J.; Pan, Y.; Li, G. Adv. Synth. Catal. 2014, 356, 2719-2724. doi:10.1002/adsc.201400032

120.Dai, Q.; Jiang, Y.; Yu, J.-T.; Cheng, J. Synthesis 2015, 48, 329-339. doi:10.1055/s-0035-1560536

121.Terent'ev, A. O.; Borisov, D. A.; Chernyshev, V. V.; Nikishin, G. I. J. Org. Chem. 2009, 74, 3335-3340. doi:10.1021/jo900226b

122.Li, Y.; Hao, H.-D.; Wu, Y. Org. Lett. 2009, 11, 2691-2694. doi:10.1021/ol900811m

123. Opsenica, D. M.; Pocsfalvi, G.; Milhous, W. K.; Šolaja, B. A. J. Serb. Chem. Soc. 2002, 67, 465-471. doi:10.2298/JSC0207465O

124.Terent'ev, A. O.; Kutkin, A. V.; Platonov, M. M.; Ogibin, Y. N.; Nikishin, G. I. Tetrahedron Lett. 2003, 44, 7359-7363. doi:10.1016/S0040-4039(03)01844-6

125.Žmitek, K.; Zupan, M.; Stavber, S.; Iskra, J. J. Org. Chem. 2007, 72, 6534-6540. doi:10.1021/jo0708745

126. Ghorai, P.; Dussault, P. H. Org. Lett. 2008, 10, 4577-4579. doi:10.1021/ol801859c

127.Amewu, R.; Stachulski, A. V.; Ward, S. A.; Berry, N. G.; Bray, P. G.; Davies, J.; Labat, G.; Vivas, L.; O'Neill, P. M. Org. Biomol. Chem. 2006, 4, 4431-4436. doi:10.1039/b613565j

128. Landenberger, K. B.; Bolton, O.; Matzger, A. J. Angew. Chem., Int. Ed. 2013, 52, 6468-6471. doi:10.1002/anie.201302814

129. Climent, E.; Gröninger, D.; Hecht, M.; Walter, M. A.; Martinez-Máñez, R.; Weller, M. G.; Sancenón, F.; Amorós, P.; Rurack, K. Chem. - Eur. J. 2013, 19, 4117-4122. doi:10.1002/chem.201300031

130.Terent'ev, A. O.; Borisov, D. A.; Yaremenko, I. A.; Chernyshev, V. V.; Nikishin, G. I. J. Org. Chem. 2010, 75, 5065-5071. doi:10.1021/jo100793j

131.Terent'ev, A. O.; Borisov, D. A.; Semenov, V. V.; Chernyshev, V. V.; Dembitsky, V. M.; Nikishin, G. I. Synthesis 2011, 2091-2100. doi:10.1055/s-0030-1260027

132.Singh, C.; Srivastav, N. C.; Puri, S. K. Bioorg. Med. Chem. 2004, 12, 5745-5752. doi:10.1016/j.bmc.2004.08.042

133.Griesbeck, A. G.; El-Idreesy, T. T.; Höinck, L.-O.; Lex, J.; Brun, R. Bioorg. Med. Chem. Lett. 2005, 15, 595-597. doi:10.1016/j.bmcl.2004.11.043

134.Singh, C.; Pandey, S.; Saxena, G.; Srivastava, N.; Sharma, M. J. Org. Chem. 2006, 71, 9057-9061. doi:10.1021/jo061414z

135.Liu, Y.-H.; Deng, J.; Gao, J.-W.; Zhang, Z.-H. Adv. Synth. Catal. 2012, 354, 441-447. doi:10.1002/adsc.201100561

136. Griesbeck, A. G.; Schlundt, V. Synlett 2011, 2430-2432. doi:10.1055/s-0030-1261225

137.Kazakov, D. V.; Kazakova, O. B.; Ishmuratov, G. Yu.; Terent'ev, A. O.; Nikishin, G. I.; Tolstikov, G. A. Dokl. Chem. 2011, 436, 34-38. doi:10.1134/S0012500811010022

138.Sashidhara, K. V.; Avula, S. R.; Singh, L. R.; Palnati, G. R. Tetrahedron Lett. 2012, 53, 4880-4884. doi:10.1016/j.tetlet.2012.07.001
139. Hall, J. F. B.; Bourne, R. A.; Han, X.; Earley, J. H.; Poliakoff, M.; George, M. W. Green Chem. 2013, 15, 177-180. doi:10.1039/C2GC36711D

140.Terent'ev, A. O.; Yaremenko, I. A.; Vil', V. A.; Moiseev, I. K.; Kon'kov, S. A.; Dembitsky, V. M.; Levitsky, D. O.; Nikishin, G. I. Org. Biomol. Chem. 2013, 11, 2613-2623. doi:10.1039/c3ob27239g

141.Terent'ev, A. O.; Yaremenko, I. A.; Chernyshev, V. V.; Dembitsky, V. M.; Nikishin, G. I. J. Org. Chem. 2012, 77, 1833-1842. doi:10.1021/jo202437r

142. Terent'ev, A. O.; Yaremenko, I. A.; Vil', V. A.; Dembitsky, V. M.; Nikishin, G. I. Synthesis 2013, 45, 246-250. doi:10.1055/s-0032-1317895

143. Nesvadba, P. Radical Polymerization in Industry. Encyclopedia of Radicals in Chemistry, Biology and Materials; John Wiley \& Sons, 2012. doi:10.1002/9781119953678.rad080

144.Moad, G.; Solomon, D. H. The chemistry of radical polymerization, 2nd ed.; Elsevier, 2006.

145. Ebewele, R. O. Polymer Science and Technology; CRC Press: Boca Raton, New York, 2000. doi:10.1201/9781420057805

146. Mark, H. F. Encyclopedia of Polymer Science and Technology, 3rd ed.; John Wiley \& Sons, 2007.

147. Matyjaszewski, K.; Davis, T. P. Future Outlook and Perspectives. Handbook of Radical Polymerization; John Wiley \& Sons, 2003; pp 895-900. doi:10.1002/0471220450.ch16

148. Hao, H.-D.; Li, Y.; Han, W.-B.; Wu, Y. Org. Lett. 2011, 13, 4212-4215. doi:10.1021/ol2015434

149.Li, Y.; Hao, H.-D.; Zhang, Q.; Wu, Y. Org. Lett. 2009, 11, 1615-1618. doi:10.1021/ol900262t

150. Yan, X.; Chen, J.; Zhu, Y.-T.; Qiao, C. Synlett 2011, 2827-2830. doi:10.1055/s-0031-1289864

151.Žmitek, K.; Zupan, M.; Stavber, S.; Iskra, J. Org. Lett. 2006, 8, 2491-2494. doi:10.1021/ol060590r

152. Azarifar, D.; Khosravi, K.; Soleimanei, F. Synthesis 2009, 2553-2556. doi:10.1055/s-0029-1217394

153. Terent'ev, A. O.; Kutkin, A. V.; Platonov, M. M.; Vorontsov, I. I.; Antipin, M. Yu.; Ogibin, Yu. N.; Nikishin, G. I. Russ. Chem. Bull. 2004, 53, 681-687. doi:10.1023/B:RUCB.0000035657.58776.cc

154.Zhang, Q.; Jin, H.-X.; Liu, H.-H.; Wu, Y.-K. Chin. J. Chem. 2006, 24, 1190-1195. doi:10.1002/cjoc.200690222

155.Zhang, Q.; Li, Y.; Wu, Y.-K. Chin. J. Chem. 2007, 25, 1304-1308. doi:10.1002/cjoc.200790242

156.Terent'ev, A. O.; Kutkin, A. V.; Platonov, M. M.; Starikova, Z. A.; Ogibin, Yu. N.; Nikishin, G. I. Russ. Chem. Bull. 2005, 54, 1214-1218. doi:10.1007/s11172-005-0383-4

157.Terent'ev, A. O.; Kutkin, A. V.; Starikova, Z. A.; Antipin, M. Yu.; Ogibin, Yu. N.; Nikishin, G. I. Synthesis 2004, 2356-2366. doi:10.1055/s-2004-831171

158. Hamann, H.-J.; Hecht, M.; Bunge, A.; Gogol, M.; Liebscher, J. Tetrahedron Lett. 2011, 52, 107-111. doi:10.1016/j.tetlet.2010.10.151

159. Terent'ev, A. O.; Platonov, M. M.; Sonneveld, E. J.; Peschar, R.; Chernyshev, V. V.; Starikova, Z. A.; Nikishin, G. I. J. Org. Chem. 2007, 72, 7237-7243. doi:10.1021/jo071072c

160. Terent'ev, A. O.; Platonov, M. M.; Krylov, I. B.; Chernyshev, V. V.; Nikishin, G. I. Org. Biomol. Chem. 2008, 6, 4435-4441. doi:10.1039/b809661a

161.Ito, T.; Tokuyasu, T.; Masuyama, A.; Nojima, M.; McCullough, K. J. Tetrahedron 2003, 59, 525-536. doi:10.1016/S0040-4020(02)01556-9

162. Terent'ev, A. O.; Borisov, A. M.; Platonov, M. M.; Starikova, Z. A.; Chernyshev, V. V.; Nikishin, G. I. Synthesis 2009, 4159-4166. doi:10.1055/s-0029-1217062 
163.Eliasen, A. M.; Thedford, R. P.; Claussen, K. R.; Yuan, C.; Siegel, D. Org. Lett. 2014, 16, 3628-3631. doi:10.1021/ol501497y

164.Hu, X.; Maimone, T. J. J. Am. Chem. Soc. 2014, 136, 5287-5290. doi:10.1021/ja502208z

165. Gamage, N.-D. H.; Stiasny, B.; Stierstorfer, J.; Martin, P. D.; Klapötke, T. M.; Winter, C. H. Chem. Commun. 2015, 51, 13298-13300. doi:10.1039/C5CC05015D

166.StarkI Renar, K.; Pečar, S.; Iskra, J. Org. Biomol. Chem. 2015, 13, 9369-9372. doi:10.1039/C5OB01503K

167.Rozhko, E.; Solmi, S.; Cavani, F.; Albini, A.; Righi, P.; Ravelli, D. J. Org. Chem. 2015, 80, 6425-6431. doi:10.1021/acs.joc.5b00861

168. Hilf, J. A.; Witthoft, L. W.; Woerpel, K. A. J. Org. Chem. 2015, 80, 8262-8267. doi:10.1021/acs.joc.5b01326

169.Lu, X.; Deng, L. Org. Lett. 2014, 16, 2358-2361. doi:10.1021/ol500677v

170. Fisher, T. J.; Mattson, A. E. Org. Lett. 2014, 16, 5316-5319. doi:10.1021/ol502494h

171.Wang, X.; Pan, Y.; Huang, K.-W.; Lai, Z. Org. Lett. 2015, 17, 5630-5633. doi:10.1021/acs.orglett.5b02881

172. Yu, H.; Shen, J. Org. Lett. 2014, 16, 3204-3207. doi:10.1021/ol5012168

173. Carney, J. M.; Hammer, R. J.; Hulce, M.; Lomas, C. M.; Miyashiro, D. Synthesis 2012, 44, 2560-2566. doi:10.1055/s-0031-1289764

174.Yan, X.; Qiao, C.; Guo, Z. Synlett 2013, 24, 502-506. doi:10.1055/s-0032-1318213

175. Hurlocker, B.; Miner, M. R.; Woerpel, K. A. Org. Lett. 2014, 16, 4280-4283. doi:10.1021/ol5020015

176. Liu, Q.; Wang, W.; Liu, Z.; Wang, T.; Wu, L.; Ge, M. RSC Adv. 2014, 4, 19716-19724. doi:10.1039/C4RA02486A

177.Parrish, J. D.; Ischay, M. A.; Lu, Z.; Guo, S.; Peters, N. R.; Yoon, T. P. Org. Lett. 2012, 14, 1640-1643. doi:10.1021/ol300428q

178.Wei, W.; Zhang, C.; Xu, Y.; Wan, X. Chem. Commun. 2011, 47, 10827-10829. doi:10.1039/c1cc14602e

179.Daeppen, C.; Kaiser, M.; Neuburger, M.; Gademann, K. Org. Lett. 2015, 17, 5420-5423. doi:10.1021/acs.orglett.5b02773

180. Kazakova, O. B.; Kazakov, D. V.; Yamansarov, E. Yu.; Medvedeva, N. I.; Tolstikov, G. A.; Suponitsky, K. Yu.; Arkhipov, D. E. Tetrahedron Lett. 2011, 52, 976-979. doi:10.1016/j.tetlet.2010.12.047

181.Lau, S.-H.; Galván, A.; Merchant, R. R.; Battilocchio, C.; Souto, J. A.; Berry, M. B.; Ley, S. V. Org. Lett. 2015, 17, 3218-3221. doi:10.1021/acs.orglett.5b01307

182. Feng, Y.; Holte, D.; Zoller, J.; Umemiya, S.; Simke, L. R.; Baran, P. S. J. Am. Chem. Soc. 2015, 137, 10160-10163. doi:10.1021/jacs.5b07154

183. Yablokov, V. A. Russ. Chem. Rev. 1980, 49, 833-842. doi:10.1070/RC1980v049n09ABEH002509 Usp. Khim. 1980, 49, 1711-1729.

184.Dussault, P. Reactions of Hydroperoxides and Peroxides. In Active Oxygen in Chemistry; Foote, C. S.; Valentine, J.; Greenberg, A.; Liebman, J., Eds.; Springer: Netherlands, 1995; Vol. 2, pp 141-203. doi:10.1007/978-94-007-0874-7_5

185.Renz, M.; Meunier, B. Eur. J. Org. Chem. 1999, 737-750. doi:10.1002/(SICI)1099-0690(199904)1999:4<737::AID-EJOC737>3.0 .CO;2-B

186. Davies, A. G. J. Chem. Res. 2009, 533-544. doi:10.3184/030823409X12491375725131

187.Syrkin, Ya. K.; Moiseev, I. I. Russ. Chem. Rev. 1960, 29, 193-214. doi:10.1070/RC1960v029n04ABEH001227 Usp. Khim. 1960, 29, 193.
188. Ishmuratov, G. Yu.; Legostaeva, Yu. V.; Botsman, L. P.; Tolstikov, G. A. Russ. J. Org. Chem. 2010, 46, 1593-1621. doi:10.1134/S1070428010110011

189.Smith, M. B. March's Advanced Organic Chemistry: Reactions, Mechanisms, and Structure, 7th ed.; John Wiley \& Sons, Inc., 2013; p 2080.

190.Wang, Z. Baeyer-Villiger Oxidation. Comprehensive Organic Name Reactions and Reagents; John Wiley \& Sons, 2010; pp 150-155. doi:10.1002/9780470638859.conrr036

191. Hassall, C. H. The Baeyer-Villiger Oxidation of Aldehydes and Ketones. In Organic Reactions; Adams, R., Ed.; John Wiley \& Sons, Inc.: New York, 2011. doi:10.1002/0471264180.or009.03

192.Baeyer, A.; Villiger, V. Ber. Dtsch. Chem. Ges. 1899, 32, 3625-3633. doi:10.1002/cber.189903203151

193. Baeyer, A.; Villiger, V. Ber. Dtsch. Chem. Ges. 1900, 33, 858-864. doi:10.1002/cber.190003301153

194.Belov, V. N.; Heyfitz, L. A.; Virezub, S. I. Okislenie karbonil'nykh soedineniy perekis'yu vodoroda i nadkislotami (reaktsiya Bayera-Villigera). Reaczii I Metodi iss/edovaniya organicheskich soedineniy; Goshimizdat: Moscow, 1961; Vol. 10, pp 7-208.

195. Krow, G. R. The Baeyer-Villiger Oxidation of Ketones and Aldehydes. In Organic Reactions; Paquette, L. A., Ed.; John Wiley \& Sons, Inc., 1993; Vol. 43, pp 251-798. doi:10.1002/0471264180.or043.03

196.Strukul, G. Angew. Chem., Int. Ed. 1998, 37, 1198-1209. doi:10.1002/(SICI)1521-3773(19980518)37:9<1198::AID-ANIE1198>3 .0.CO;2-Y

197. Chida, N.; Tobe, T.; Ogawa, S. Tetrahedron Lett. 1994, 35, 7249-7252. doi:10.1016/0040-4039(94)85373-8

198. Butkus, E.; Stončius, S. J. Chem. Soc., Perkin Trans. 12001 , 1885-1888. doi:10.1039/b103564a

199.Doering, W. v. E.; Speers, L. J. Am. Chem. Soc. 1950, 72, 5515-5518. doi:10.1021/ja01168a041

200.ten Brink, G.-J.; Arends, I. W. C. E.; Sheldon, R. A. Chem. Rev. 2004, 104, 4105-4124. doi:10.1021/cr030011।

201.Lambert, A.; Macquarrie, D. J.; Carr, G.; Clark, J. H. New J. Chem. 2000, 24, 485-488. doi:10.1039/b003161p

202. Chang, C. D.; Hellring, S. D. Shape-selective oxidation of cyclic ketones. U.S. Patent US4,870,192, Sept 26, 1989.

203. Fischer, J.; Hölderich, W. F. Appl. Catal., A 1999, 180, 435-443. doi:10.1016/S0926-860X(98)00378-0

204. Taylor, R. T.; Flood, L. A. J. Org. Chem. 1983, 48, 5160-5164. doi:10.1021/jo00174a003

205. Jacobson, S. E.; Mares, F.; Zambri, P. M. J. Am. Chem. Soc. 1979, 101, 6938-6946. doi:10.1021/ja00517a025

206. Sandaroos, R.; Goldani, M. T.; Damavandi, S.; Mohammadi, A. J. Chem. Sci. 2012, 124, 871-876. doi:10.1007/s12039-012-0277-6

207. Hoelderich, W. P. D.; Fischer, J.; Schindler, G. P. D.; Arntz, D. D. Verfahren zur Herstellung von Lactonen durch Baeyer-Villiger Oxidation. Ger. Patent DE19,745,442 A1, April 22, 1999. Chem. Abstr. 1999, 130, 281989u.

208. Gavagnin, R.; Cataldo, M.; Pinna, F.; Strukul, G. Organometallics 1998, 17, 661-667. doi:10.1021/om970756f

209.Bolm, C.; Beckmann, O. Chirality 2000, 12, 523-525. doi:10.1002/(SICI)1520-636X(2000)12:5/6<523::AID-CHIR39>3.0.CO; $2-Z$

210.Phillips, A. M. F.; Romão, C. Eur. J. Org. Chem. 1999, 1767-1770. doi:10.1002/(SICI)1099-0690(199908)1999:8<1767::AID-EJOC1767> 3.0.CO;2-S

211. Herrmann, W. A.; Fischer, R. W.; Correia, J. D. G. J. Mol. Catal. 1994, 94, 213-223. doi:10.1016/S0304-5102(94)87043-8 
212.ten Brink, G.-J.; Vis, J.-M.; Arends, I. W. C. E.; Sheldon, R. A. J. Org. Chem. 2001, 66, 2429-2433. doi:10.1021/jo0057710

213.Grieco, P. A.; Yokoyama, Y.; Gilman, S.; Ohfune, Y. J. Chem. Soc., Chem. Commun. 1977, 870-871. doi:10.1039/c39770000870

214.Jacobson, S. E.; Tang, R.; Mares, F. J. Chem. Soc., Chem. Commun. 1978, 888-889. doi:10.1039/c39780000888

215.Uchida, T.; Katsuki, T.; Ito, K.; Akashi, S.; Ishii, A.; Kuroda, T. Helv. Chim. Acta 2002, 85, 3078-3089. doi:10.1002/1522-2675(200210)85:10<3078::AID-HLCA3078>3.0.CO; 2-1

216. Berkessel, A.; Andreae, M. R. M. Tetrahedron Lett. 2001, 42, 2293-2295. doi:10.1016/S0040-4039(01)00141-1

217. McClure, J. D.; Williams, P. H. J. Org. Chem. 1962, 27, 24-26. doi:10.1021/jo01048a005

218. Macias-Alonso, M.; Morzycki, J. W.; Iglesias-Arteaga, M. A. Steroids 2011, 76, 317-323. doi:10.1016/j.steroids.2010.12.004

219. Carlqvist, P.; Eklund, R.; Hult, K.; Brinck, T. J. Mol. Model. 2003, 9 , 164-171. doi:10.1007/s00894-003-0128-y

220.Bach, R. D. J. Org. Chem. 2012, 77, 6801-6815. doi:10.1021/jo300727w

221. Hitomi, Y.; Yoshida, H.; Tanaka, T.; Funabiki, T. J. Mol. Catal. A: Chem. 2006, 251, 239-245. doi:10.1016/j.molcata.2006.02.002

222. Yamabe, S.; Yamazaki, S. J. Org. Chem. 2007, 72, 3031-3041. doi:10.1021/jo0626562

223. Hamann, H.-J.; Bunge, A.; Liebscher, J. Chem. - Eur. J. 2008, 14, 6849-6851. doi:10.1002/chem.200800932

224.Gordon, N. J.; Evans, S. A., Jr. J. Org. Chem. 1993, 58, 4516-4519. doi:10.1021/jo00069a004

225.Enders, D.; Geibel, G.; Osborne, S. Chem. - Eur. J. 2000, 6, 1302-1309. doi:10.1002/(SICI)1521-3765(20000417)6:8<1302::AID-CHEM1302>3 .0.CO;2-J

226. Iglesias-Arteaga, M. A.; Velazquez-Huerta, G. A.; Mendez-Stivalet, J. M.; Galano, A.; Alvarez-ldaboy, J. R. ARKIVOC 2006, No. vi, 109-126.

227.Zhou, G.; Corey, E. J. J. Am. Chem. Soc. 2005, 127, 11958-11959. doi:10.1021/ja054503m

228.Sharrna, R.; Nikas, S. P.; Guo, J. J.; Mallipeddi, S.; Wood, J. T.; Makriyannis, A. ACS Med. Chem. Lett. 2014, 5, 400-404. doi: $10.1021 / \mathrm{ml} 4005304$

229.Peris, G.; Miller, S. J. Org. Lett. 2008, 10, 3049-3052. doi:10.1021/ol8010248

230.Patil, N. D.; Yao, S. G.; Meier, M. S.; Mobley, J. K.; Crocker, M. Org. Biomol. Chem. 2015, 13, 3243-3254. doi:10.1039/C4OB01771D

231.Poladura, B.; Martínez-Castañeda, Á.; Rodríguez-Solla, H.; Llavona, R.; Concellón, C.; del Amo, V. Org. Lett. 2013, 15, 2810-2813. doi:10.1021/ol401143q

232. Goodman, M. A.; Detty, M. R. Synlett 2006, 1100-1104. doi:10.1055/s-2006-939692

233. Yu, L.; Wu, Y.; Cao, H.; Zhang, X.; Shi, X.; Luan, J.; Chen, T.; Pan, Y.; Xu, Q. Green Chem. 2014, 16, 287-293. doi:10.1039/C3GC41562G

234.ten Brink, G.-J.; Vis, J. M.; Arends, I. W. C. E.; Sheldon, R. A. Tetrahedron 2002, 58, 3977-3983. doi:10.1016/S0040-4020(02)00248-X

235. Ichikawa, H.; Usami, Y.; Arimoto, M. Tetrahedron Lett. 2005, 46, 8665-8668. doi:10.1016/j.tetlet.2005.10.055

236.Zhang, X.; Ye, J.; Yu, L.; Shi, X.; Zhang, M.; Xu, Q.; Lautens, M. Adv. Synth. Catal. 2015, 357, 955-960. doi:10.1002/adsc.201400957
237.Yu, L.; Bai, Z.; Zhang, X.; Zhang, X.; Ding, Y.; Xu, Q. Catal. Sci. Technol. 2016, 6, 1804-1809. doi:10.1039/C5CY01395J

238. Del Todesco Frisone, M.; Giovanetti, R.; Pinna, F.; Strukul, G. Stud. Surf. Sci. Catal. 1991, 66, 405-410. doi:10.1016/S0167-2991(08)62858-X

239.Bolm, C.; Schlingloff, G.; Weickhardt, K. Angew. Chem., Int. Ed. Engl. 1994, 33, 1848-1849. doi:10.1002/anie.199418481

240.Bolm, C.; Schlingloff, G.; Bienewald, F. J. Mol. Catal. A: Chem. 1997, 117, 347-350. doi:10.1016/S1381-1169(96)00359-7

241.Gusso, A.; Baccin, C.; Pinna, F.; Strukul, G. Organometallics 1994, 13, 3442-3451. doi:10.1021/om00021a019

242.Strukul, G.; Varagnolo, A.; Pinna, F. J. Mol. Catal. A: Chem. 1997, 117, 413-423. doi:10.1016/S1381-1169(96)00246-4

243.Lopp, M.; Paju, A.; Kanger, T.; Pehk, T. Tetrahedron Lett. 1996, 37, 7583-7586. doi:10.1016/0040-4039(96)01666-8

244. Ito, K.; Ishii, A.; Kuroda, T.; Katsuki, T. Synlett 2003, 643-646. doi:10.1055/s-2003-38377

245. Petersen, K. S.; Stoltz, B. M. Tetrahedron 2011, 67, 4352-4357. doi:10.1016/j.tet.2011.04.046

246. Michelin, R. A.; Sgarbossa, P.; Scarso, A.; Strukul, G. Coord. Chem. Rev. 2010, 254, 646-660. doi:10.1016/j.ccr.2009.09.014

247.Bernini, R.; Coratti, A.; Provenzano, G.; Fabrizi, G.; Tofani, D. Tetrahedron 2005, 61, 1821-1825. doi:10.1016/j.tet.2004.12.025

248.Wang, Y.; Yokoi, T.; Otomo, R.; Kondo, J. N.; Tatsumi, T. Appl. Catal., A 2015, 490, 93-100. doi:10.1016/j.apcata.2014.11.011

249.Luo, H. Y.; Bui, L.; Gunther, W. R.; Min, E.; Román-Leshkov, Y. ACS Catal. 2012, 2, 2695-2699. doi:10.1021/cs300543z

250.Kang, Z.; Zhang, X.; Liu, H.; Qiu, J.; Yeung, K. L. Chem. Eng. J. 2013, 218, 425-432. doi:10.1016/j.cej.2012.12.019

251.Paul, M.; Pal, N.; Mondal, J.; Sasidharan, M.; Bhaumik, A. Chem. Eng. Sci. 2012, 71, 564-572. doi:10.1016/j.ces.2011.11.038

252. Nabae, Y.; Rokubuichi, H.; Mikuni, M.; Kuang, Y.; Hayakawa, T.; Kakimoto, M.-a. ACS Catal. 2013, 3, 230-236. doi:10.1021/cs3007928

253.Uyanik, M.; Nakashima, D.; Ishihara, K. Angew. Chem. 2012, 124 , 9227-9230. doi:10.1002/ange.201204286

254. Uyanik, M.; Ishihara, K. ACS Catal. 2013, 3, 513-520. doi:10.1021/cs300821u

255. Nicolaou, K. C.; Yu, R.; Shi, L.; Cai, Q.; Lu, M.; Heretsch, P. Org. Lett. 2013, 15, 1994-1997. doi:10.1021/ol4006689

256.Hu, Y.-L.; Li, D.-J.; Li, D.-S. RSC Adv. 2015, 5, 24936-24943. doi:10.1039/C5RA02234G

257. House, H. O.; Wasson, R. L. J. Org. Chem. 1957, 22, 1157-1160. doi:10.1021/jo01361a005

258. Kaneda, K.; Ueno, S.; Imanaka, T. J. Mol. Catal. A: Chem. 1995, 102, 135-138. doi:10.1016/1381-1169(95)00055-0

259. Kaneda, K.; Yamashita, T. Tetrahedron Lett. 1996, 37, 4555-4558. doi:10.1016/0040-4039(96)00902-1

260.Pillai, U. R.; Sahle-Demessie, E. J. Mol. Catal. A: Chem. 2003, 191, 93-100. doi:10.1016/S1381-1169(02)00347-3

261. Bradley, T. D.; Dragan, A.; Tomkinson, N. C. O. Tetrahedron 2015, 71, 8155-8161. doi:10.1016/j.tet.2015.08.037

262. Ito, K. Asymmetric Baeyer-Villiger Oxidation. In Comprehensive Chirality; Carreira, E. M.; Yamamoto, H., Eds.; Elsevier: Amsterdam, 2012; pp 1-35. doi:10.1016/B978-0-08-095167-6.00502-4

263. Bryliakov, K. P. Sustainable Asymmetric Oxidations. In Comprehensive Inorganic Chemistry, 2nd ed.; Poeppelmeier, J. R., Ed.; Elsevier: Amsterdam, 2013; pp 625-664. doi:10.1016/B978-0-08-097774-4.00624-0 
264.Leisch, H.; Morley, K.; Lau, P. C. K. Chem. Rev. 2011, 111, 4165-4222. doi:10.1021/cr1003437

265. Mihovilovic, M. D.; Müller, B.; Stanetty, P. Eur. J. Org. Chem. 2002, 3711-3730. doi:10.1002/1099-0690(200211)2002:22<3711::AID-EJOC3711>3.0.C $0 ; 2-5$

266. Mihovilovic, M. D.; Rudroff, F.; Winninger, A.; Schneider, T.; Schulz, F.; Reetz, M. T. Org. Lett. 2006, 8, 1221-1224. doi:10.1021/ol0601040

267.Reetz, M. T.; Brunner, B.; Schneider, T.; Schulz, F.; Clouthier, C. M.; Kayser, M. M. Angew. Chem., Int. Ed. 2004, 43, 4075-4078. doi:10.1002/anie.200460272

268.Baldwin, C. V. F.; Wohlgemuth, R.; Woodley, J. M. Org. Process Res. Dev. 2008, 12, 660-665. doi:10.1021/op800046t

269. Schallmey, A.; Domínguez de María, P.; Bracco, P. Biocatalytic Asymmetric Oxidations in Stereoselective Synthesis. In Stereoselective Synthesis of Drugs and Natural Products; Andrushko, V.; Andrushko, N., Eds.; John Wiley \& Sons, Inc.: Hoboken, New Jersey, 2013; Vol. 2. doi:10.1002/9781118596784.ssd036

270.Reile, I.; Paju, A.; Müürisepp, A.-M.; Pehk, T.; Lopp, M. Tetrahedron 2011, 67, 5942-5948. doi:10.1016/j.tet.2011.06.036

271.Jõgi, A.; Paju, A.; Pehk, T.; Kailas, T.; Müürisepp, A.-M.; Kanger, T.; Lopp, M. Synthesis 2006, 3031-3036. doi:10.1055/s-2006-950193

272.Paju, A.; Laos, M.; Jõgi, A.; Päri, M.; Jäälaid, R.; Pehk, T.; Kanger, T.; Lopp, M. Tetrahedron Lett. 2006, 47, 4491-4493. doi:10.1016/j.tetlet.2006.04.013

273. Crudden, C. M.; Chen, A. C.; Calhoun, L. A. Angew. Chem., Int. Ed. 2000, 39, 2851-2855. doi:10.1002/1521-3773(20000818)39:16<2851::AID-ANIE2851>3.0.C O;2-Y

274.Xu, S.; Wang, Z.; Zhang, X.; Zhang, X.; Ding, K.

Angew. Chem., Int. Ed. 2008, 47, 2840-2843. doi:10.1002/anie.200705932

275.Xu, S.; Wang, Z.; Li, Y.; Zhang, X.; Wang, H.; Ding, K. Chem. - Eur. J. 2010, 16, 3021-3035. doi:10.1002/chem.200902698

276.Xu, S.; Wang, Z.; Zhang, X.; Ding, K. Chin. J. Chem. 2010, 28, 1731-1735. doi:10.1002/cjoc.201090292

277.Xu, S.; Wang, Z.; Zhang, X.; Ding, K. Eur. J. Org. Chem. 2011, 110-116. doi:10.1002/ejoc.201001130

278. Mazzini, C.; Lebreton, J.; Furstoss, R. J. Org. Chem. 1996, 61, 8-9. doi:10.1021/jo951905b

279. Murahashi, S.-I.; Ono, S.; Imada, Y. Angew. Chem., Int. Ed. 2002, 41, 2366-2368.

doi:10.1002/1521-3773(20020703)41:13<2366::AID-ANIE2366>3.0.C O;2-S

280.van Berkel, W. J. H.; Kamerbeek, N. M.; Fraaije, M. W. J. Biotechnol. 2006, 124, 670-689. doi:10.1016/j.jbiotec.2006.03.044

281.Černuchová, P.; Mihovilovic, M. D. Org. Biomol. Chem. 2007, 5, 1715-1719. doi:10.1039/B703175K

282.Schulz, F.; Leca, F.; Hollmann, F.; Reetz, M. T. Beilstein J. Org. Chem. 2005, 1, No. 10. doi:10.1186/1860-5397-1-10

283.Zhou, L.; Liu, X.; Ji, J.; Zhang, Y.; Hu, X.; Lin, L.; Feng, X. J. Am. Chem. Soc. 2012, 134, 17023-17026. doi:10.1021/ja309262f

284.Zhou, L.; Liu, X.; Ji, J.; Zhang, Y.; Wu, W.; Liu, Y.; Lin, L.; Feng, X. Org. Lett. 2014, 16, 3938-3941. doi:10.1021/ol501737a

285.Romney, D. K.; Colvin, S. M.; Miller, S. J. J. Am. Chem. Soc. 2014, 136, 14019-14022. doi:10.1021/ja508757g

286. Terent'ev, A. O.; Chodykin, S. V. Cent. Eur. J. Chem. 2005, 3, 417-431. doi:10.2478/BF02479272
287.Putic, A.; Stecher, L.; Prinz, H.; Müller, K. Eur. J. Med. Chem. 2010, 45, 3299-3310. doi:10.1016/j.ejmech.2010.04.013

288.An, G.-i.; Kim, M.; Kim, J. Y.; Rhee, H. Tetrahedron Lett. 2003, 44 , 2183-2186. doi:10.1016/S0040-4039(03)00156-4

289.Kao, J. P. Y.; Muralidharan, S.; Zavalij, P. Y.; Fletcher, S.; Xue, F.; Rosen, G. M. Tetrahedron Lett. 2014, 55, 3111-3113. doi:10.1016/j.tetlet.2014.04.004

290.Wang, Z. Criegee Rearrangement. Comprehensive Organic Name Reactions and Reagents; John Wiley \& Sons, 2010; pp 770-774. doi:10.1002/9780470638859.conrr170

291. Criegee, R. Ber. Dtsch. Chem. Ges. A 1945, 77, 722-726. doi:10.1002/cber.19450770912

292. Hedaya, E.; Winstein, S. Tetrahedron Lett. 1962, 3, 563-567. doi:10.1016/S0040-4039(00)76930-9

293. Hedaya, E.; Winstein, S. J. Am. Chem. Soc. 1967, 89, 1661-1672. doi:10.1021/ja00983a023

294. Wistuba, E.; Rüchardt, C. Tetrahedron Lett. 1981, 22, 3389-3392. doi:10.1016/S0040-4039(01)81913-4

295.Schreiber, S. L.; Liew, W.-F. Tetrahedron Lett. 1983, 24, 2363-2366. doi:10.1016/S0040-4039(00)81926-7

296. Goodman, R. M.; Kishi, Y. J. Org. Chem. 1994, 59, 5125-5127. doi:10.1021/jo00097a006

297. Ogibin, Y. N.; Terent'ev, A. O.; Kutkin, A. V.; Nikishin, G. I. Tetrahedron Lett. 2002, 43, 1321-1324. doi:10.1016/S0040-4039(01)02368-1

298. Baumstark, A. L.; Vasquez, P. C.; Chen, Y.-X. J. Org. Chem. 1994, 59, 6692-6696. doi:10.1021/jo00101a030

299. Krasutsky, P. A.; Kolomitsyn, I. V.; Krasutsky, S. G.; Kiprof, P. Org. Lett. 2004, 6, 2539-2542. doi:10.1021/ol049171p

300. Krasutsky, P. A.; Kolomitsyn, I. V. ARKIVOC 2005, No. iv, 151-171.

301. Srikrishna, A.; Reddy, T. J. Tetrahedron 1998, 54, 11517-11524. doi:10.1016/S0040-4020(98)00672-3

302.Srikrishna, A.; Kumar, P. P.; Reddy, T. J. Tetrahedron Lett. 1998, 39, 5815-5818. doi:10.1016/S0040-4039(98)01148-4

303. Srikrishna, A.; Anebouselvy, K. J. Org. Chem. 2001, 66, 7102-7106. doi:10.1021/jo0105484

304.Srikrishna, A.; Gharpure, S. J.; Kumar, P. P. Tetrahedron Lett. 2000, 41, 3177-3180. doi:10.1016/S0040-4039(00)00325-7

305. Srikrishna, A.; Anebouselvy, K.; Reddy, T. J. Tetrahedron Lett. 2000, 41, 6643-6647. doi:10.1016/S0040-4039(00)01107-2

306. Srikrishna, A.; Anebouselvy, K. Tetrahedron Lett. 2002, 43, 2769-2771. doi:10.1016/S0040-4039(02)00382-9

307. Srikrishna, A.; Mahesh, K. Synlett 2011, 2537-2540. doi:10.1055/s-0030-1260326

308. Gándara, Z.; Rivadulla, M. L.; Pérez, M.; Gómez, G.; Fall, Y. Eur. J. Org. Chem. 2013, 5678-5682. doi:10.1002/ejoc.201300528

309. Taatjes, C. A.; Shallcross, D. E.; Percival, C. J. Phys. Chem. Chem. Phys. 2014, 16, 1704-1718. doi:10.1039/c3cp52842a

310. Chao, W.; Hsieh, J.-T.; Chang, C.-H.; Lin, J. J.-M. Science 2015, 347, 751-754. doi:10.1126/science.1261549

311.Liu, F.; Beames, J. M.; Petit, A. S.; McCoy, A. B.; Lester, M. I. Science 2014, 345, 1596-1598. doi:10.1126/science.1257158

312.Welz, O.; Savee, J. D.; Osborn, D. L.; Vasu, S. S.; Percival, C. J.; Shallcross, D. E.; Taatjes, C. A. Science 2012, 335, 204-207. doi:10.1126/science.1213229

313.Wang, Z. Hock Rearrangement. Comprehensive Organic Name Reactions and Reagents; John Wiley \& Sons, 2010; pp 1438-1442. doi:10.1002/9780470638859.conrr321 
314.Udris, R. J.; Sergeyev, P. G.; Kruzhalov, B. D. Sposob polucheniya gidroperekisejj alkilirovannykh-proizvodnykh benzola ili alicikloaromaticheskikh uglevodorodov. USSR Patent 106,666, Jan 7, 1947.

315.Sergeyev, P. G.; Udris, R. J.; Kruzhalov, B. D.; Nyemtsov, B. D. Sposob odnovremennogo polucheniya fenola i acetona. USSR Patent 106,992, Jan 7, 1947.

316. Hock, H.; Lang, S. Ber. Dtsch. Chem. Ges. A 1944, 77, 257-264. doi:10.1002/cber.19440770321

317. Hock, H.; Kropf, H. Angew. Chem. 1957, 69, 313-321. doi:10.1002/ange.19570691002

318.Deno, N. C.; Billups, W. E.; Kramer, K. E.; Lastomirsky, R. R. J. Org. Chem. 1970, 35, 3080-3082. doi:10.1021/jo00834a046

319. Olah, G. A.; Parker, D. G.; Yoneda, N. Angew. Chem., Int. Ed. Engl. 1978, 17, 909-931. doi:10.1002/anie.197809091

320.Lange, J.-P.; Breed, A. J. M. Catal. Commun. 2002, 3, 25-28. doi:10.1016/S1566-7367(01)00071-1

321. Lillie, T. S.; Ronald, R. C. J. Org. Chem. 1985, 50, 5084-5088. doi:10.1021/jo00225a018

322. Fisher, T. J.; Dussault, P. H. Tetrahedron Lett. 2010, 51, 5615-5617. doi:10.1016/j.tetlet.2010.08.068

323. Anderson, G. H.; Smith, J. G. Can. J. Chem. 1968, 46, 1561-1570. doi:10.1139/v68-256

324.Hamann, H.-J.; Liebscher, J. J. Org. Chem. 2000, 65, 1873-1876. doi:10.1021/jo991457y

325. Hamann, H.-J.; Liebscher, J. Synlett 2001, 96-98. doi:10.1055/s-2001-9704

326. Chan, Y.-Y.; Zhu, C.; Leung, H.-K. J. Am. Chem. Soc. 1985, 107, 5274-5275. doi:10.1021/ja00304a041

327.Chan, Y.-Y.; Li, X.; Zhu, C.; Liu, X.; Zhang, Y.; Leung, H.-K. J. Org. Chem. 1990, 55, 5497-5504. doi:10.1021/j000307a022

328. Kabalka, G. W.; Reddy, N. K.; Narayana, C. Tetrahedron Lett. 1993, 34, 7667-7668. doi:10.1016/S0040-4039(00)61534-4

329.Boger, D. L.; Coleman, R. S. J. Org. Chem. 1986, 51, 5436-5439. doi:10.1021/jo00376a079

330.Zheng, X.; Lu, S.; Li, Z. Org. Lett. 2013, 15, 5432-5435. doi:10.1021/ol402509u

331.Zheng, X.; Lv, L.; Lu, S.; Wang, W.; Li, Z. Org. Lett. 2014, 16, 5156-5159. doi:10.1021/ol5025053

332.Louillat-Habermeyer, M.-L.; Jin, R.; Patureau, F. W. Angew. Chem., Int. Ed. 2015, 54, 4102-4104. doi:10.1002/anie.201500089

333.Boger, D. L.; Coleman, R. S. Tetrahedron Lett. 1987, 28, 1027-1030. doi:10.1016/S0040-4039(00)95902-1

334.Amara, Z.; Bellamy, J. F. B.; Horvath, R.; Miller, S. J.; Beeby, A.; Burgard, A.; Rossen, K.; Poliakoff, M.; George, M. W. Nat. Chem. 2015, 7, 489-495. doi:10.1038/nchem.2261

335. Wang, Z. Kornblum-Delamare Rearrangement. Comprehensive Organic Name Reactions and Reagents; John Wiley \& Sons, Inc., 2010; pp 1675-1678. doi:10.1002/9780470638859.conrr374

336. Kornblum, N.; DeLaMare, H. E. J. Am. Chem. Soc. 1951, 73, 880-881. doi:10.1021/ja01146a542

337. Mete, E.; Altundaş, R.; Seçen, H.; Balci, M. Turk. J. Chem. 2003, 27, 145-153.

338. Akbulut, N.; Balci, M. J. Org. Chem. 1988, 53, 3338-3342. doi:10.1021/jo00249a039

339. Kelly, D. R.; Bansal, H.; Morgan, J. J. G. Tetrahedron Lett. 2002, 43, 9331-9333. doi:10.1016/S0040-4039(02)02374-2

340.Avery, T. D.; Taylor, D. K.; Tiekink, E. R. T. J. Org. Chem. 2000, 65, 5531-5546. doi:10.1021/jo0002240
341.Greatrex, B. W.; Kimber, M. C.; Taylor, D. K.; Tiekink, E. R. T. J. Org. Chem. 2003, 68, 4239-4246. doi:10.1021/jo020700h

342. Greatrex, B. W.; Taylor, D. K.; Tiekink, E. R. T. J. Org. Chem. 2004, 69, 2580-2583. doi:10.1021/jo0303315

343.Zhang, X.; Khan, S. I.; Foote, C. S. J. Org. Chem. 1993, 58, 7839-7847. doi:10.1021/jo00079a032

344. Schulte-Elte, K. H.; Willhalm, B.; Ohloff, G. Angew. Chem. 1969, 81, 1045. doi:10.1002/ange.19690812406

345.Staben, S. T.; Linghu, X.; Toste, F. D. J. Am. Chem. Soc. 2006, 128, 12658-12659. doi:10.1021/ja065464x

346. Oda, M.; Kitahara, Y. Tetrahedron Lett. 1969, 10, 3295-3296. doi:10.1016/S0040-4039(01)88413-6

347.Daştan, A.; Balci, M. Tetrahedron 2006, 62, 4003-4010. doi:10.1016/j.tet.2006.02.026

348.Koc, F.; Cadirci, E.; Albayrak, A.; Halici, Z.; Hacimuftuoglu, A.; Suleyman, H. Med. Chem. Res. 2010, 19, 84-93. doi:10.1007/s00044-009-9174-z

349. Morita, Y.; Matsumura, E.; Okabe, T.; Shibata, M.; Sugiura, M.; Ohe, T.; Tsujibo, H.; Ishida, N.; Inamori, Y. Biol. Pharm. Bull. 2003, 26, 1487-1490. doi:10.1248/bpb.26.1487

350.Balci, M.; Atasoy, B. Tetrahedron Lett. 1984, 25, 4033-4036. doi:10.1016/0040-4039(84)80059-3

351.Atasoy, B.; Balci, M. Tetrahedron 1986, 42, 1461-1468. doi:10.1016/S0040-4020(01)87365-8

352.Sengül, M. E.; Ceylan, Z.; Balci, M. Tetrahedron 1997, 53, 10401-10408. doi:10.1016/S0040-4020(97)00630-3

353. Güney, M.; Ceylan, Z. C.; Daştan, A.; Balci, M. Can. J. Chem. 2005, 83, 227-235. doi:10.1139/v05-046

354.Gu, X.; Zhang, W.; Salomon, R. G. J. Org. Chem. 2012, 77, 1554-1559. doi:10.1021/jo201910g

355. Kawasumi, M.; Kanoh, N.; Iwabuchi, Y. Org. Lett. 2011, 13, 3620-3623. doi:10.1021/ol201273b

356.Paddock, V. L.; Phipps, R. J.; Conde-Angulo, A.; Blanco-Martin, A.; Giró-Mañas, C.; Martin, L. J.; White, A. J. P.; Spivey, A. C. J. Org. Chem. 2011, 76, 1483-1486. doi:10.1021/jo102314w

357. Fujishima, T.; Kitoh, F.; Yano, T.; Irie, R. Synlett 2010, 2279-2282. doi:10.1055/s-0030-1258028

358.Erden, I.; Öcal, N.; Song, J.; Gleason, C.; Gärtner, C. Tetrahedron 2006, 62, 10676-10682. doi:10.1016/j.tet.2006.07.107

359. Wasserman, H. H.; Terao, S. Tetrahedron Lett. 1975, 16, 1735-1738. doi:10.1016/S0040-4039(00)72246-5

360. Frimer, A. A. Chem. Rev. 1979, 79, 359-387. doi:10.1021/cr60321a001

361. Hewton, C. E.; Kimber, M. C.; Taylor, D. K. Tetrahedron Lett. 2002, 43, 3199-3201. doi:10.1016/S0040-4039(02)00503-8

362.Rössle, M.; Werner, T.; Baro, A.; Frey, W.; Christoffers, J. Angew. Chem., Int. Ed. 2004, 43, 6547-6549. doi:10.1002/anie.200461406

363.Zhang, F.; Du, P.; Chen, J.; Wang, H.; Luo, Q.; Wan, X. Org. Lett. 2014, 16, 1932-1935. doi:10.1021/ol5004687

364.Greatrex, B. W.; Jenkins, N. F.; Taylor, D. K.; Tiekink, E. R. T. J. Org. Chem. 2003, 68, 5205-5210. doi:10.1021/jo0300845

365.Zagorski, M. G.; Salomon, R. G. J. Am. Chem. Soc. 1980, 102, 2501-2503. doi:10.1021/ja00527a081

366.Zagorski, M. G.; Salomon, R. G. J. Am. Chem. Soc. 1984, 106, 1750-1759. doi:10.1021/ja00318a034

367. Nicolaou, K. C.; Totokotsopoulos, S.; Giguère, D.; Sun, Y.-P.; Sarlah, D. J. Am. Chem. Soc. 2011, 133, 8150-8153. doi:10.1021/ja2032635 
368.Buchanan, G. S.; Cole, K. P.; Tang, Y.; Hsung, R. P. J. Org. Chem. 2011, 76, 7027-7039. doi:10.1021/jo200936r

369. Kumar, R. A.; Maheswari, C. U.; Ghantasala, S.; Jyothi, C.; Reddy, K. R. Adv. Synth. Catal. 2011, 353, 401-410. doi:10.1002/adsc. 201000580

370.Tan, H.; Chen, X.; Liu, Z.; Wang, D. Z. Tetrahedron 2012, 68, 3952-3955. doi:10.1016/j.tet.2012.03.076

371.Gesinski, M. R.; Brenzovich, W. E., Jr.; Staben, S. T.; Srinilta, D. J.; Toste, F. D. Tetrahedron Lett. 2015, 56, 3643-3646. doi:10.1016/j.tetlet.2015.02.067

372.Wiegand, C.; Herdtweck, E.; Bach, T. Chem. Commun. 2012, 48, 10195-10197. doi:10.1039/c2cc35621j

373.Palframan, M. J.; Kociok-Köhn, G.; Lewis, S. E. Chem. - Eur. J. 2012, 18, 4766-4774. doi:10.1002/chem.201104035

374.Du, P.; Li, H.; Wang, Y.; Cheng, J.; Wan, X. Org. Lett. 2014, 16, 6350-6353. doi:10.1021/ol503128j

375.Liu, C.; Shi, E.; Xu, F.; Luo, Q.; Wang, H.; Chen, J.; Wan, X. Chem. Commun. 2015, 51, 1214-1217. doi:10.1039/C4CC07833K

376.Jiang, J.; Liu, J.; Yang, L.; Shao, Y.; Cheng, J.; Bao, X.; Wan, X. Chem. Commun. 2015, 51, 14728-14731. doi:10.1039/C5CC05183E

377.Chen, I. T.; Baitinger, I.; Schreyer, L.; Trauner, D. Org. Lett. 2014, 16, 166-169. doi:10.1021/ol403156r

378.Zhang, M.; Liu, N.; Tang, W. J. Am. Chem. Soc. 2013, 135 , 12434-12438. doi:10.1021/ja406255j

379.Priest, J.; Longland, M. R.; Elsegood, M. R. J.; Kimber, M. C. J. Org. Chem. 2013, 78, 3476-3481. doi:10.1021/jo400177j

380. Hugelshofer, C. L.; Magauer, T. J. Am. Chem. Soc. 2015, 137, 3807-3810. doi:10.1021/jacs.5b02021

381. Kalaitzakis, D.; Triantafyllakis, M.; Alexopoulou, I.; Sofiadis, M.; Vassilikogiannakis, G. Angew. Chem., Int. Ed. 2014, 53, 13201-13205. doi:10.1002/anie.201407477

382. Vassilikogiannakis, G.; Stratakis, M. Angew. Chem., Int. Ed. 2003, 42, 5465-5468. doi:10.1002/anie.200352180

383.Vassilikogiannakis, G.; Margaros, I.; Montagnon, T. Org. Lett. 2004, 6, 2039-2042. doi:10.1021/ol0493610

384. Vassilikogiannakis, G.; Margaros, I.; Montagnon, T.; Stratakis, M. Chem. - Eur. J. 2005, 11, 5899-5907. doi:10.1002/chem.200401311

385.Dakin, H. D. Am. Chem. J. 1909, 42, 477-498.

386.Wang, Z. Dakin Reaction. Comprehensive Organic Name Reactions and Reagents; John Wiley \& Sons, 2010; pp 829-831. doi:10.1002/9780470638859.conrr175

387. Hocking, M. B.; Bhandari, K.; Shell, B.; Smyth, T. A. J. Org. Chem. 1982, 47, 4208-4215. doi:10.1021/jo00143a007

388. Varma, R. S.; Naicker, K. P. Org. Lett. 1999, 1, 189-192. doi:10.1021/ol990522n

389. da Silva, E. T.; Câmara, C. A.; Antunes, O. A. C.; Barreiro, E. J.; Fraga, C. A. M. Synth. Commun. 2008, 38, 784-788. doi:10.1080/00397910701820673

390.Chen, S.; Hossain, M. S.; Foss, F. W., Jr. Org. Lett. 2012, 14 , 2806-2809. doi:10.1021/ol3010326

391.Chen, S.; Foss, F. W., Jr. Org. Lett. 2012, 14, 5150-5153. doi:10.1021/ol302479b

392. Saikia, B.; Borah, P.; Barua, N. C. Green Chem. 2015, 17, 4533-4536. doi:10.1039/C5GC01404B

393.Abe, T.; Itoh, T.; Choshi, T.; Hibino, S.; Ishikura, M. Tetrahedron Lett. 2014, 55, 5268-5270. doi:10.1016/j.tetlet.2014.07.113

394.Jung, M. E.; Lazarova, T. I. J. Org. Chem. 1997, 62, 1553-1555. doi:10.1021/jo962099r
395. Faure, E.; Falentin-Daudré, C.; Jérôme, C.; Lyskawa, J.; Fournier, D.; Woisel, P.; Detrembleur, C. Prog. Polym. Sci. 2013, 38, 236-270. doi:10.1016/j.progpolymsci.2012.06.004

396. Fache, M.; Darroman, E.; Besse, V.; Auvergne, R.; Caillol, S.; Boutevin, B. Green Chem. 2014, 16, 1987-1998. doi:10.1039/c3gc42613k

397.Fache, M.; Boutevin, B.; Caillol, S. Green Chem. 2016, 18, 712-725. doi:10.1039/C5GC01070E

398. Matsumoto, M.; Kobayashi, H.; Hotta, Y. J. Org. Chem. 1984, 49, 4740-4741. doi:10.1021/jo00198a037

399. Roy, A.; Reddy, K. R.; Mohanta, P. K.; Ila, H.; Junjappat, H. Synth. Commun. 1999, 29, 3781-3791. doi:10.1080/00397919908086017

400. Elbs, K. J. Prakt. Chem. 1893, 48, 179-185. doi:10.1002/prac. 18930480123

401. Wang, Z. Elbs Persulfate Oxidation. Comprehensive Organic Name Reactions and Reagents; John Wiley \& Sons, 2010; pp 977-981. doi:10.1002/9780470638859.conrr212

402. Behrman, E. J. Beilstein J. Org. Chem. 2006, 2, No. 22. doi:10.1186/1860-5397-2-22

403.Behrman, E. C.; Chen, S.; Behrman, E. J. Tetrahedron Lett. 2002, 43, 3221-3224. doi:10.1016/S0040-4039(02)00495-1

404. Capdevielle, P.; Maumy, M. Tetrahedron Lett. 1982, 23, 1573-1576. doi:10.1016/S0040-4039(00)87161-0

405. Sethna, S. M. Chem. Rev. 1951, 49, 91-101. doi:10.1021/cr60152a002

406. Behrman, E. J. Synth. Commun. 2008, 38, 1168-1175. doi:10.1080/00397910701865819

407.Behrman, E. J. Chem. Cent. J. 2009, 3, No. 1. doi:10.1186/1752-153X-3-1

408.Behrman, E. J. J. Chem. Res. 2014, 38, 121-122. doi:10.3184/174751914X13896383516701

409. Schenck, G. O.; Neumüller, O.-A.; Eisfeld, W. Justus Liebigs Ann. Chem. 1958, 618, 202-210. doi:10.1002/jlac.19586180123

410.Schenck, G. O.; Neumüller, O.-A.; Eisfeld, W. Angew. Chem. 1958, 70, 595. doi:10.1002/ange.19580701906

411. Eistert, B.; Bock, G. Angew. Chem. 1958, 70, 595. doi:10.1002/ange.19580701905

412.Teng, J. I.; Kulig, M. J.; Smith, L. L.; Kan, G.; Van Lier, J. E. J. Org. Chem. 1973, 38, 119-123. doi:10.1021/jo00941a024

413. Porter, N. A.; Dussault, P. H. Rearrangements of optically pure hydroperoxides. In Free Radicals in Synthesis and Biology; Minisci, F., Ed.; Kluwer Academic Publishers, 1989; pp 407-421. doi:10.1007/978-94-009-0897-0_30

414.Brill, W. F. J. Chem. Soc., Perkin Trans. 2 1984, 621-627. doi:10.1039/p29840000621

415.Porter, N.; Zuraw, P. J. Chem. Soc., Chem. Commun. 1985, 1472-1473. doi:10.1039/c39850001472

416. Beckwith, A. L. J.; Davies, A. G.; Davison, I. G. E.; Maccoll, A.; Mruzek, M. H. J. Chem. Soc., Perkin Trans. 2 1989, 815-824. doi:10.1039/P29890000815

417.Porter, N. A.; Wujek, J. S. J. Org. Chem. 1987, 52, 5085-5089. doi:10.1021/jo00232a004

418.Beckwith, A. L. J.; Davies, A. G.; Davison, I. G. E.; Maccoll, A.; Mruzek, M. H. J. Chem. Soc., Chem. Commun. 1988, 475-476. doi:10.1039/c39880000475

419. Davies, A. G.; Davison, I. G. E. J. Chem. Soc., Perkin Trans. 2 1989, 825-830. doi:10.1039/p29890000825 
420.Porter, N. A.; Kaplan, J. K.; Dussault, P. H. J. Am. Chem. Soc. 1990, 112, 1266-1267. doi:10.1021/ja00159a068

421.Porter, N. A.; Mills, K. A.; Caldwell, S. E.; Dubay, G. R. J. Am. Chem. Soc. 1994, 116, 6697-6705. doi:10.1021/ja00094a027

422. Mills, K. A.; Caldwell, S. E.; Dubay, G. R.; Porter, N. A. J. Am. Chem. Soc. 1992, 114, 9689-9691. doi:10.1021/ja00050a076

423.Lowe, J. R.; Porter, N. A. J. Am. Chem. Soc. 1997, 119, 11534-11535. doi:10.1021/ja9723038

424.Brill, W. F. J. Am. Chem. Soc. 1965, 87, 3286-3287. doi:10.1021/ja01092a077

425.Dussault, P. H.; Eary, C. T.; Woller, K. R. J. Org. Chem. 1999, 64, 1789-1797. doi:10.1021/jo981128q

426.Dang, H. S.; Davies, A. G.; Davison, I. G. E.; Schiesser, C. H. J. Org. Chem. 1990, 55, 1432-1438. doi:10.1021/jo00292a012

427.Avila, D. V.; Davies, A. G.; Davison, I. G. E. J. Chem. Soc., Perkin Trans. 2 1988, 1847-1852. doi:10.1039/p29880001847

428.Dang, H.-S.; Davies, A. G. J. Chem. Soc., Perkin Trans. 2 1992, 1095-1101. doi:10.1039/P29920001095

429. Dussault, P. H.; Woller, K. R. J. Am. Chem. Soc. 1997, 119, 3824-3825. doi:10.1021/ja970174p

430.Nonami, Y.; Baran, J.; Sosnicki, J.; Mayr, H.; Masuyama, A.; Nojima, M. J. Org. Chem. 1999, 64, 4060-4063. doi:10.1021/jo990127a

431.Bortolomeazzi, R.; De Zan, M.; Pizzale, L.; Conte, L. S. J. Agric. Food Chem. 1999, 47, 3069-3074. doi:10.1021/jf9812580

432.Sy, L.-K.; Ngo, K.-S.; Brown, G. D. Tetrahedron 1999, 55 , 15127-15140. doi:10.1016/S0040-4020(99)00987-4

433. Ngo, K.-S.; Brown, G. D. Tetrahedron 1999, 55, 14623-14634. doi:10.1016/S0040-4020(99)00938-2

434.Ponce, M. A.; Ramirez, J. A.; Galagovsky, L. R.; Gros, E. G.; Erra-Balsells, R. J. Chem. Soc., Perkin Trans. 2 2000, 2351-2358. doi:10.1039/b000144i

435. Kinart, W. J.; Kinart, A.; Sendecki, M. Phys. Chem. Liq. 2008, 46, 627-630. doi:10.1080/00319100802072656

436.Wentworth, A. D.; Song, B.-D.; Nieva, J.; Shafton, A.; Tripurenani, S.; Wentworth, P., Jr. Chem. Commun. 2009, 3098-3100. doi:10.1039/B821584G

437.Chen, D.; Chen, W.; Liu, D.; van Ofwegen, L.; Proksch, P.; Lin, W. J. Nat. Prod. 2013, 76, 1753-1763. doi:10.1021/np400480p

438. Pratt, D. A.; Tallman, K. A.; Porter, N. A. Acc. Chem. Res. 2011, 44, 458-467. doi:10.1021/ar200024c

439.Dang, H.-S.; Davies, A. G.; Schiesser, C. H. J. Chem. Soc., Perkin Trans. 11990, 3, 789-794. doi:10.1039/p19900000789

440. Courtneidge, J. L. J. Chem. Soc., Chem. Commun. 1992, 1270-1272. doi:10.1039/c39920001270

441.Wieland, H. Ber. Dtsch. Chem. Ges. 1911, 44, 2550-2556. doi:10.1002/cber.19110440380

442.Ingold, K. U.; Smeu, M.; DiLabio, G. A. J. Org. Chem. 2006, 71, 9906-9908. doi:10.1021/jo061898z

443.DiLabio, G. A.; Ingold, K. U.; Lin, S.; Litwinienko, G.; Mozenson, O.; Mulder, P.; Tidwell, T. T. Angew. Chem., Int. Ed. 2010, 49, 5982-5985. doi:10.1002/anie.201001008

444.Dannley, R. L.; Farrant, G. C. J. Org. Chem. 1969, 34, 2432-2437. doi:10.1021/jo01260a037

445.Dannley, R. L.; Shubber, A. K. J. Org. Chem. 1971, 36, 3784-3787. doi:10.1021/jo00823a027

446. Terent'ev, A. O.; Platonov, M. M.; Kashin, A. S.; Nikishin, G. I. Tetrahedron 2008, 64, 7944-7948. doi:10.1016/j.tet.2008.06.027
447.Payne, G. B.; Smith, C. W. J. Org. Chem. 1957, 22, 1682-1685. doi:10.1021/jo01363a042

448. Payne, G. J. Org. Chem. 1959, 24, 1830-1832. doi:10.1021/jo01093a633

449. Terent'ev, A. O.; Borisov, D. A.; Yaremenko, I. A.; Ogibin, Y. N.; Nikishin, G. I. Synthesis 2010, 1145-1149. doi:10.1055/s-0029-1219225

450. Yaremenko, I. A.; Terent'ev, A. O.; Vil', V. A.; Novikov, R. A.; Chernyshev, V. V.; Tafeenko, V. A.; Levitsky, D. O.; Fleury, F.; Nikishin, G. I. Chem. - Eur. J. 2014, 20, 10160-10169. doi:10.1002/chem.201402594

451.Yu, X.; Liu, Z.; Xia, Z.; Shen, Z.; Pan, X.; Zhang, H.; Xie, W. RSC Adv. 2014, 4, 53397-53401. doi:10.1039/C4RA11237G

452. Dussault, P. H.; Lee, H.-J.; Liu, X. J. Chem. Soc., Perkin Trans. 1 2000, 3006-3013. doi:10.1039/b001391i

453. Murahashi, S.-I.; Naota, T.; Miyaguchi, N.; Noda, S. J. Am. Chem. Soc. 1996, 118, 2509-2510. doi:10.1021/ja954009q

454. Murahashi, S.-I.; Miyaguchi, N.; Noda, S.; Naota, T.; Fujii, A.; Inubushi, Y.; Komiya, N. Eur. J. Org. Chem. 2011, 5355-5365. doi:10.1002/ejoc.201100740

455. Mal, D.; Ray, S.; Sharma, I. J. Org. Chem. 2007, 72, 4981-4984. doi:10.1021/jo062271j

456. Murahashi, S.-I.; Fujii, A.; Inubushi, Y.; Komiya, N. Tetrahedron Lett. 2010, 51, 2339-2341. doi:10.1016/j.tetlet.2010.02.134

457. O'Neill, P. M.; Rawe, S. L.; Storr, R. C.; Ward, S. A.; Posner, G. H. Tetrahedron Lett. 2005, 46, 3029-3032. doi:10.1016/j.tetlet.2005.03.022

458. Afonso, A. Can. J. Chem. 1970, 48, 691-693. doi:10.1139/v70-113

459. Kulinkovich, O. G.; Astashko, D. A.; Tyvorskii, V. I.; Ilyina, N. A. Synthesis 2001, 1453-1455. doi:10.1055/s-2001-16089

460. Reisinger, C. M.; Wang, X.; List, B. Angew. Chem., Int. Ed. 2008, 47, 8112-8115. doi:10.1002/anie.200803238

461. O'Neill, P. M.; Searle, N. L.; Raynes, K. J.; Maggs, J. L.; Ward, S. A.; Storr, R. C.; Park, B. K.; Posner, G. H. Tetrahedron Lett. 1998, 39, 6065-6068. doi:10.1016/S0040-4039(98)01248-9

462.Bernat, V.; André, C.; André-Barrès, C. Org. Biomol. Chem. 2008, 6, 454-457. doi:10.1039/b715491g

463. Hoshiya, N.; Watanabe, N.; Ijuin, H. K.; Matsumoto, M. Tetrahedron 2006, 62, 12424-12437. doi:10.1016/j.tet.2006.09.108

464. Matsumoto, M.; Akimoto, T.; Matsumoto, Y.; Watanabe, N. Tetrahedron Lett. 2005, 46, 6075-6078. doi:10.1016/j.tetlet.2005.07.008

465. Matsumoto, M.; Tanimura, M.; Akimoto, T.; Watanabe, N.; ljuin, H. K. Tetrahedron Lett. 2008, 49, 4170-4173. doi:10.1016/j.tetlet.2008.04.110

466. Tanimura, M.; Watanabe, N.; Ijuin, H. K.; Matsumoto, M. J. Org. Chem. 2011, 76, 902-908. doi:10.1021/j01021822

467. Tanimura, M.; Watanabe, N.; ljuin, H. K.; Matsumoto, M. J. Org. Chem. 2012, 77, 4725-4731. doi:10.1021/jo300417e

468. Matsumoto, M.; Suzuki, H.; Sano, Y.; Watanabe, N.; ljuin, H. K. Tetrahedron Lett. 2008, 49, 5372-5375. doi:10.1016/j.tetlet.2008.06.103

469. Matsumoto, M.; Suzuki, H.; Watanabe, N.; Ijuin, H. K.; Tanaka, J.; Tanaka, C. J. Org. Chem. 2011, 76, 5006-5017. doi:10.1021/jo2006945

470. Matsumoto, M.; Takamido, Y.; Nomura, K.; Shiono, T.; Watanabe, N.; Ijuin, H. K. Tetrahedron Lett. 2008, 49, 6145-6147. doi:10.1016/j.tetlet.2008.08.024

471. Turan, I. S.; Akkaya, E. U. Org. Lett. 2014, 16, 1680-1683. doi:10.1021/ol5003412 
472.Watanabe, N.; Kikuchi, M.; Maniwa, Y.; ljuin, H. K.; Matsumoto, M. J. Org. Chem. 2010, 75, 879-884. doi:10.1021/jo902477n

473.Watanabe, N.; Sano, Y.; Suzuki, H.; Tanimura, M.; Ijuin, H. K.; Matsumoto, M. J. Org. Chem. 2010, 75, 5920-5926. doi:10.1021/jo101114b

474.Koyama, Y.; Watanabe, N.; ljuin, H. K.; Matsumoto, M. Heterocycles 2015, 90, 462-481. doi:10.3987/COM-14-S(K)43

475. Hagiwara, H.; Watanabe, N.; ljuin, H. K.; Yamada, M.; Matsumoto, M. Heterocycles 2013, 87, 65-78. doi:10.3987/COM-12-12602

476. Bastos, E. L.; da Silva, S. M.; Baader, W. J. J. Org. Chem. 2013, 78, 4432-4439. doi:10.1021/j0400426y

477. Ciscato, L. F. M. L.; Bartoloni, F. H.; Colavite, A. S.; Weiss, D.; Beckert, R.; Schramm, S. Photochem. Photobiol. Sci. 2014, 13, 32-37. doi:10.1039/C3PP50345C

478. Klaper, M.; Wessig, P.; Linker, T. Chem. Commun. 2016, 52, 1210-1213. doi:10.1039/C5CC08606J

479.Pramanik, S.; Reddy, R. R.; Ghorai, P. Org. Lett. 2015, 17, 1393-1396. doi:10.1021/acs.orglett.5b00190

480.Story, P. R.; Denson, D. D.; Bishop, C. E.; Clark, B. C., Jr.; Farine, J.-C. J. Am. Chem. Soc. 1968, 90, 817-818. doi:10.1021/ja01005a063

481.Sanderson, J. R.; Story, P. R. J. Org. Chem. 1974, 39, 3463-3469. doi:10.1021/jo00938a001

482.Sanderson, J. R.; Story, P. R.; Paul, K. J. Org. Chem. 1975, 40, 691-695. doi:10.1021/jo00894a006

483.Paul, K.; Story, P. R.; Busch, P.; Sanderson, J. R. J. Org. Chem. 1976, 41, 1283-1285. doi:10.1021/jo00869a054

484.Boyd, J. D.; Foote, C. S. J. Am. Chem. Soc. 1979, 101, 6758-6759. doi:10.1021/ja00516a051

485. Celik, M.; Akbulut, N.; Balci, M. Helv. Chim. Acta 2000, 83, 3131-3138. doi:10.1002/1522-2675(20001220)83:12<3131::AID-HLCA3131>3.0.C 0;2-6

486.van Tamelen, E. E.; Taylor, E. G. J. Am. Chem. Soc. 1980, 102, 1202-1203. doi:10.1021/ja00523a067

487. Carless, H. A. J.; Atkins, R.; Fekarurhobo, G. K. Tetrahedron Lett. 1985, 26, 803-806. doi:10.1016/S0040-4039(00)89142-X

488. Maheshwari, K. K.; de Mayo, P.; Wiegand, D. Can. J. Chem. 1970, 48, 3265-3268. doi:10.1139/v70-548

489. Wilson, R. M.; Rekers, J. W. J. Am. Chem. Soc. 1981, 103, 206-207. doi:10.1021/ja00391a046

490.Ronzani, F.; Costarramone, N.; Blanc, S.; Benabbou, A. K.; Le Bechec, M.; Pigot, T.; Oelgemöller, M.; Lacombe, S. J. Catal. 2013, 303, 164-174. doi:10.1016/j.jcat.2013.04.001

491.Delort, E.; Jaquier, A.; Decorzant, E.; Chapuis, C.; Casilli, A.; Frérot, E. Phytochemistry 2015, 109, 111-124. doi:10.1016/j.phytochem.2014.10.023

492.El-Mansy, M. F.; Flister, M.; Lindeman, S.; Kalous, K.; Sem, D. S.; Donaldson, W. A. Chem. - Eur. J. 2015, 21, 10886-10895. doi:10.1002/chem.201501274

493.Erden, I.; Xu, F.-P.; Drummond, J.; Alstad, R. J. Org. Chem. 1993, 58, 3611-3612. doi:10.1021/jo00066a007

494.Erden, I.; Xu, F.-P.; Cao, W.-G. Angew. Chem., Int. Ed. Engl. 1997, 36, 1516-1518. doi:10.1002/anie.199715161

495. Cermola, F.; lesce, M. R.; Buonerba, G. J. Org. Chem. 2005, 70, 6503-6505. doi:10.1021/jo0504159

496.Scarpati, R.; lesce, M. R.; Cermola, F.; Guitto, A. Synlett 1998, 17-25. doi:10.1055/s-1998-1556 497.lesce, M. R.; Cermola, F.; De Lorenzo, F.; Orabona, I.; Graziano, M. L. J. Org. Chem. 2001, 66, 4732-4735. doi:10.1021/jo0102112

498. Matsumoto, M.; Murakami, H.; Watanabe, N. Chem. Commun. 1998, 2319-2320. doi:10.1039/a806823b

499. Matsumoto, M.; Sano, Y.; Watanabe, N.; ljuin, H. K. Chem. Lett. 2006, 35, 882-883. doi:10.1246/cl.2006.882

500.Lee, A. S.; Shair, M. D. Org. Lett. 2013, 15, 2390-2393. doi:10.1021/ol400832r

501.Ronsein, G. E.; de Oliveira, M. C. B.; de Medeiros, M. H. G.; Di Mascio, P. Photochem. Photobiol. Sci. 2011, 10, 1727-1730. doi:10.1039/c1pp05181d

502.Posner, G. H.; Tao, X.; Cumming, J. N.; Klinedinst, D.; Shapiro, T. A. Tetrahedron Lett. 1996, 37, 7225-7228. doi:10.1016/0040-4039(96)01625-5

503.Suzuki, M.; Ohtake, H.; Kameya, Y.; Hamanaka, N.; Noyori, R. J. Org. Chem. 1989, 54, 5292-5302. doi:10.1021/jo00283a023

504.Kamata, M.; Satoh, C.; Kim, H.-S.; Wataya, Y. Tetrahedron Lett. 2002, 43, 8313-8317. doi:10.1016/S0040-4039(02)02024-5

505.Bloodworth, A. J.; Shah, A. Tetrahedron Lett. 1995, 36, 7551-7554. doi:10.1016/0040-4039(95)01530-2

506.Liu, H.-H.; Jin, H.-X.; Wu, Y.-K. Chin. J. Chem. 2004, 22, 1029-1033. doi:10.1002/cjoc.20040220930

507.Persico, M.; Quintavalla, A.; Rondinelli, F.; Trombini, C.; Lombardo, M.; Fattorusso, C.; Azzarito, V.; Taramelli, D.; Parapini, S.; Corbett, Y.; Chianese, G.; Fattorusso, E.; Taglialatela-Scafati, O. J. Med. Chem. 2011, 54, 8526-8540. doi:10.1021/jm201056j

508.Liu, H.-H.; Wu, Y.-K.; Shen, X. Chin. J. Chem. 2003, 21, 875-877. doi:10.1002/cjoc.20030210731

509.Boyd, J. D.; Foote, C. S.; Imagawa, D. K. J. Am. Chem. Soc. 1980, 102, 3641-3642. doi:10.1021/ja00530a063

510.Baran, A.; Bekarlar, M.; Aydin, G.; Nebioglu, M.; Sahin, E.; Balci, M. J. Org. Chem. 2012, 77, 1244-1250. doi:10.1021/jo202494v

511.Baran, A.; Cambul, S.; Nebioglu, M.; Balci, M. J. Org. Chem. 2012, 77, 5086-5097. doi:10.1021/jo300655p

512. Özen, R.; Kormali, F.; Balci, M.; Atasoy, B. Tetrahedron 2001, 57, 7529-7535. doi:10.1016/S0040-4020(01)00702-5

513. Coşkun, A.; Güney, M.; Daştan, A.; Balci, M. Tetrahedron 2007, 63, 4944-4950. doi:10.1016/j.tet.2007.03.145

514.Griffen, J. A.; Kenwright, S. J.; Abou-Shehada, S.; Wharry, S.; Moody, T. S.; Lewis, S. E. Org. Chem. Front. 2014, 1, 79-90. doi:10.1039/c3qo00057e

515.Özer, G.; Saraçoglu, N.; Balci, M. J. Org. Chem. 2003, 68, 7009-7015. doi:10.1021/j00345300

516. Kiliç, H.; Balci, M. Tetrahedron 2001, 57, 9889-9897. doi:10.1016/S0040-4020(01)01008-0

517.Dastan, A.; Saracoglu, N.; Balci, M. Eur. J. Org. Chem. 2001, 3519-3522. doi:10.1002/1099-0690(200109)2001:18<3519::AID-EJOC3519>3.0.C $0 ; 2-2$

518.Adam, W.; Balci, M.; Kiliç, H. J. Org. Chem. 2000, 65, 5926-5931. doi:10.1021/jo000120p

519.Sutbeyaz, Y.; Seçen, H.; Balci, M. J. Org. Chem. 1988, 53, 2312-2317. doi:10.1021/jo00245a034

520.Durie, A. J.; Slawin, A. M. Z.; Lebl, T.; Kirsch, P.; O'Hagan, D. Chem. Commun. 2011, 47, 8265-8267. doi:10.1039/c1cc13016a

521.Sar, A.; Lindeman, S.; Donaldson, W. A. Org. Biomol. Chem. 2010, 8 , 3908-3917. doi:10.1039/c004730a

522.Barbarow, J. E.; Miller, A. K.; Trauner, D. Org. Lett. 2005, 7, 2901-2903. doi:10.1021/ol050831f 
523. Miller, A. K.; Trauner, D. Angew. Chem., Int. Ed. 2005, 44, 4602-4606. doi:10.1002/anie.200500488

524.Suzuki, M.; Oda, Y.; Hamanaka, N.; Noyori, R. Heterocycles 1990, 30, 517-535. doi:10.3987/COM-89-S45

525.Suzuki, M.; Oda, Y.; Noyori, R. Tetrahedron Lett. 1981, 22 , 4413-4416. doi:10.1016/S0040-4039(01)82971-3

526. The Research Group of Artemisinin Structure. Chin. Sci. Bull. 1977, 22, 142.

527. The Qinghaosu Antimalarial Coordinating Research Group. Chin. Med. J. (Beijing, China, Engl. Ed.) 1979, 92, 811-816.

528. Chaturvedi, D.; Goswami, A.; Saikia, P. P.; Barua, N. C.; Rao, P. G. Chem. Soc. Rev. 2010, 39, 435-454. doi:10.1039/B816679J

529.Chen, H.-J.; Han, W.-B.; Hao, H.-D.; Wu, Y. Tetrahedron 2013, 69, 1112-1114. doi:10.1016/j.tet.2012.11.056

530. Opsenica, D. M.; Solaja, B. A. Maced. J. Chem. Chem. Eng. 2012, 31, 137-182.

531.Schmid, G.; Hofheinz, W. J. Am. Chem. Soc. 1983, 105, 624-625. doi:10.1021/ja00341a054

532. Yadav, J. S.; Thirupathaiah, B.; Srihari, P. Tetrahedron 2010, 66, 2005-2009. doi:10.1016/j.tet.2010.01.051

533.Zhu, C.; Cook, S. P. J. Am. Chem. Soc. 2012, 134, 13577-13579. doi:10.1021/ja3061479

534.Dong, Y.; Wittlin, S.; Sriraghavan, K.; Chollet, J.; Charman, S. A.; Charman, W. N.; Scheurer, C.; Urwyler, H.; Santo Tomas, J.; Snyder, C.; Creek, D. J.; Morizzi, J.; Koltun, M.; Matile, H.; Wang, X.; Padmanilayam, M.; Tang, Y.; Dorn, A.; Brun, R.; Vennerstrom, J. L. J. Med. Chem. 2010, 53, 481-491. doi:10.1021/jm901473s

535. Uhlemann, A.-C.; Wittlin, S.; Matile, H.; Bustamante, L. Y.; Krishna, S. Antimicrob. Agents Chemother. 2007, 51, 667-672. doi:10.1128/AAC.01064-06

536. Vennerstrom, J. L.; Arbe-Barnes, S.; Brun, R.; Charman, S. A.; Chiu, F. C. K.; Chollet, J.; Dong, Y.; Dorn, A.; Hunziker, D.; Matile, H.; McIntosh, K.; Padmanilayam, M.; Santo Tomas, J.; Scheurer, C.; Scorneaux, B.; Tang, Y.; Urwyler, H.; Wittlin, S.; Charman, W. N. Nature 2004, 430, 900-904. doi:10.1038/nature02779

537.O'Neill, P. M.; Amewu, R. K.; Nixon, G. L.; ElGarah, F. B.; Mungthin, M.; Chadwick, J.; Shone, A. E.; Vivas, L.; Lander, H.; Barton, V.; Muangnoicharoen, S.; Bray, P. G.; Davies, J.; Park, B. K.; Wittlin, S.; Brun, R.; Preschel, M.; Zhang, K.; Ward, S. A. Angew. Chem., Int. Ed. 2010, 49, 5693-5697. doi:10.1002/anie.201001026

538.Edikpo, N.; Ghasi, S.; Elias, A.; Oguanobi, N. Mol. Cell. Pharmacol. 2013, 5, 75-89.

539. Klonis, N.; Creek, D. J.; Tilley, L. Curr. Opin. Microbiol. 2013, 16, 722-727. doi:10.1016/j.mib.2013.07.005

540. Li, J.; Zhou, B. Molecules 2010, 15, 1378-1397. doi: $10.3390 /$ molecules 15031378

541.Robert, A.; Bonduelle, C.; Laurent, S. A.-L.; Meunier, B. J. Phys. Org. Chem. 2006, 19, 562-569. doi:10.1002/poc.1059

542.Pereira, M. S. C.; Kiralj, R.; Ferreira, M. M. C. J. Chem. Inf. Model. 2008, 48, 85-98. doi:10.1021/ci700011f

543. Creek, D. J.; Chiu, F. C. K.; Prankerd, R. J.; Charman, S. A.; Charman, W. N. J. Pharm. Sci. 2005, 94, 1820-1829. doi:10.1002/jps.20400

544.Bousejra-El Garah, F.; Meunier, B.; Robert, A. Eur. J. Inorg. Chem. 2008, 2133-2135. doi:10.1002/ejic.200800129

545. Haynes, R. K.; Chan, W. C.; Lung, C.-M.; Uhlemann, A.-C.; Eckstein, U.; Taramelli, D.; Parapini, S.; Monti, D.; Krishna, S. ChemMedChem 2007, 2, 1480-1497. doi:10.1002/cmdc.200700108
546. Moles, P.; Oliva, M.; Safont, V. S. J. Phys. Chem. B 2011, 115, 333-346. doi:10.1021/jp1064903

547. Navacchia, M. L.; Capobianco, M. L.; D'Angelantonio, M.; Marconi, G. Tetrahedron Lett. 2012, 53, 1296-1299. doi:10.1016/j.tetlet.2012.01.007

548.Nosoongnoen, W.; Pratuangdejkul, J.; Sathirakul, K.; Jacob, A.; Conti, M.; Loric, S.; Launay, J.-M.; Manivet, P. Phys. Chem. Chem. Phys. 2008, 10, 5083-5093. doi:10.1039/b804516j

549. O'Neill, P. M.; Barton, V. E.; Ward, S. A. Molecules 2010, 15, 1705-1721. doi:10.3390/molecules15031705

550.Robert, A.; Benoit-Vical, F.; Meunier, B. Coord. Chem. Rev. 2005, 249, 1927-1936. doi:10.1016/j.ccr.2004.12.022

551.Tang, Y.; Dong, Y.; Wang, X.; Sriraghavan, K.; Wood, J. K.; Vennerstrom, J. L. J. Org. Chem. 2005, 70, 5103-5110. doi:10.1021/j0050385+

552.Posner, G. H.; Cumming, J. N.; Ploypradith, P.; Oh, C. H. J. Am. Chem. Soc. 1995, 117, 5885-5886. doi:10.1021/ja00126a042

553. Taglialatela-Scafati, O.; Fattorusso, E.; Romano, A.; Scala, F.; Barone, V.; Cimino, P.; Stendardo, E.; Catalanotti, B.; Persico, M.; Fattorusso, C. Org. Biomol. Chem. 2010, 8, 846-856. doi:10.1039/B918600J

554.André-Barrès, C.; Najjar, F.; Bottalla, A.-L.; Massou, S.; Zedde, C.; Baltas, M.; Gorrichon, L. J. Org. Chem. 2005, 70, 6921-6924. doi:10.1021/jo050439f

555.Najjar, F.; Gorrichon, L.; Baltas, M.; André-Barrès, C.; Vial, H. Org. Biomol. Chem. 2005, 3, 1612-1614. doi:10.1039/b503402g

556. Bousejra-El Garah, F.; Wong, M. H.-L.; Amewu, R. K.; Muangnoicharoen, S.; Maggs, J. L.; Stigliani, J.-L.; Park, B. K.; Chadwick, J.; Ward, S. A.; O'Neill, P. M. J. Med. Chem. 2011, 54, 6443-6455. doi:10.1021/jm200768h

557.Creek, D. J.; Charman, W. N.; Chiu, F. C. K.; Prankerd, R. J.; Dong, Y.; Vennerstrom, J. L.; Charman, S. A. Antimicrob. Agents Chemother. 2008, 52, 1291-1296. doi:10.1128/AAC.01033-07

558. Robert, A.; Coppel, Y.; Meunier, B. Inorg. Chim. Acta 2002, 339, 488-496. doi:10.1016/S0020-1693(02)00940-4

559.Jourdan, J.; Matile, H.; Reift, E.; Biehlmaier, O.; Dong, Y.; Wang, X. Mäser, P.; Vennerstrom, J. L.; Wittlin, S. ACS Infect. Dis. 2016, 2, 54-61. doi:10.1021/acsinfecdis.5b00090

560. Kimura, K.-i.; Sakamoto, Y.; Fujisawa, N.; Uesugi, S.; Aburai, N.; Kawada, M.; Ohba, S.-i.; Yamori, T.; Tsuchiya, E.; Koshino, H. Bioorg. Med. Chem. 2012, 20, 3887-3897. doi:10.1016/j.bmc.2012.04.025

561. Davies, K. J. A. IUBMB Life 2000, 50, 279-289. doi: $10.1080 / 713803728$

562. Arai, H. Oxidative Modification of Lipoproteins. In Lipid Hydroperoxide-Derived Modification of Biomolecules; Kato, Y., Ed.; Springer: Netherlands, 2014; Vol. 77, pp 103-114. doi:10.1007/978-94-007-7920-4_9

563. Mohd Fauzi, N.; Spickett, C. Lipid Oxidation. In Studies on Experimental Toxicology and Pharmacology; Roberts, S. M.; Kehrer, J. P.; Klotz, L.-O., Eds.; Springer International Publishing, 2015; pp 43-79. doi:10.1007/978-3-319-19096-9_4

564. Cadet, J.; Di Mascio, P. Peroxides in Biological Systems. PATAl'S Chemistry of Functional Groups; John Wiley \& Sons, Ltd., 2009. doi:10.1002/9780470682531.pat0357

565. Jahn, U.; Galano, J.-M.; Durand, T. Angew. Chem., Int. Ed. 2008, 47, 5894-5955. doi:10.1002/anie.200705122 
566. Porter, N. A. J. Org. Chem. 2013, 78, 3511-3524. doi:10.1021/j04001433

567.Ricciotti, E.; FitzGerald, G. A. Arterioscler., Thromb., Vasc. Biol. 2011, 31, 986-1000. doi:10.1161/ATVBAHA.110.207449

568. Roberts, L. J.; Fessel, J. P. Chem. Phys. Lipids 2004, 128, 173-186. doi:10.1016/j.chemphyslip.2003.09.016

569. Yin, H.; Havrilla, C. M.; Morrow, J. D.; Porter, N. A. J. Am. Chem. Soc. 2002, 124, 7745-7754. doi:10.1021/ja0201092

570. Yin, H.; Xu, L.; Porter, N. A. Chem. Rev. 2011, 111, 5944-5972. doi:10.1021/cr200084z

571.Itri, R.; Junqueira, H. C.; Mertins, O.; Baptista, M. S. Biophys. Rev. 2014, 6, 47-61. doi:10.1007/s12551-013-0128-9

572.Xu, L.; Porter, N. A. Free Radical Res. 2015, 49, 835-849. doi:10.3109/10715762.2014.985219

573. Miyoshi, N.; Iuliano, L.; Tomono, S.; Ohshima, H. Biochem. Biophys. Res. Commun. 2014, 446, 702-708. doi:10.1016/j.bbrc.2013.12.107

574.Costas, M.; Mehn, M. P.; Jensen, M. P.; Que, L., Jr. Chem. Rev. 2004, 104, 939-986. doi:10.1021/cr020628n

575.Sainsbury, P. D.; Mineyeva, Y.; Mycroft, Z.; Bugg, T. D. H. Bioorg. Chem. 2015, 60, 102-109. doi:10.1016/j.bioorg.2015.05.002

576.Guzik, U.; Hupert-Kocurek, K.; Wojcieszyńska, D. Intradiol Dioxygenases - The Key Enzymes in Xenobiotics Degradation. In Biodegradation of Hazardous and Special Products; Chamy, R.; Rosenkranz, F., Eds.; InTech, 2013. doi:10.5772/56205

577. Komatsuzaki, H.; Shiota, A.; Hazawa, S.; Itoh, M.; Miyamura, N.; Miki, N.; Takano, Y.; Nakazawa, J.; Inagaki, A.; Akita, M.; Hikichi, S. Chem. - Asian J. 2013, 8, 1115-1119. doi:10.1002/asia.201300029

578.Arnold, A.; Metzinger, R.; Limberg, C. Chem. - Eur. J. 2015, 21, 1198-1207. doi:10.1002/chem.201405155

579.Poureskandari, M.; Safaei, E.; Sajjadi, S. M.; Karimpour, T.; Jaglicic, Z.; Lee, Y.-I. J. Mol. Struct. 2015, 1094, 130-136. doi:10.1016/j.molstruc.2015.04.008

580.Borowski, T.; Siegbahn, P. E. M. J. Am. Chem. Soc. 2006, 128, 12941-12953. doi:10.1021/ja0641251

581. Mendel, S.; Arndt, A.; Bugg, T. D. H. Biochemistry 2004, 43, 13390-13396. doi:10.1021/bi048518t

582. Kovaleva, E. G.; Rogers, M. S.; Lipscomb, J. D. Biochemistry 2015, 54, 5329-5339. doi:10.1021/acs.biochem.5b00709

583. Váradi, T.; Pap, J. S.; Giorgi, M.; Párkányi, L.; Csay, T.; Speier, G.; Kaizer, J. Inorg. Chem. 2013, 52, 1559-1569. doi:10.1021/ic302378r

584.Xin, M.; Bugg, T. D. H. J. Am. Chem. Soc. 2008, 130, 10422-10430. doi:10.1021/ja8029569

585. Harrison, P. J.; Bugg, T. D. H. Arch. Biochem. Biophys. 2014, 544, 105-111. doi:10.1016/j.abb.2013.10.005

586. Harrison, P. J.; Newgas, S. A.; Descombes, F.; Shepherd, S. A.; Thompson, A. J.; Bugg, T. D. H. FEBS J. 2015, 282, 3986-4000. doi:10.1111/febs. 13400

\section{License and Terms}

This is an Open Access article under the terms of the Creative Commons Attribution License

(http://creativecommons.org/licenses/by/2.0), which permits unrestricted use, distribution, and reproduction in any medium, provided the original work is properly cited.

The license is subject to the Beilstein Journal of Organic Chemistry terms and conditions:

(http://www.beilstein-journals.org/bjoc)

The definitive version of this article is the electronic one which can be found at:

doi:10.3762/bjoc. 12.162 